\title{
MODULES FOR ESTIMATING SOLID WASTE FROM FOSSIL-FUEL TECHNOLOGIES
}

M.A. Crowther, H.C. Thode Jr., and S.C. Morris

October 1980

BIOMEDICAL AND ENVIRONMENTAL ASSESSMENT DIVISION

MATIONAL CENTER FOR ANALYSIS OF ENERGY SYSTEMS

DEPARTMENT OF ENERGY AND ENVIRONMENT

BROOKHAVEN NATIONAL LABORATORY

ASSOCIATED UNIVERSITIES, INC.

UNDER CONTRACT NO. DE-ACO2-76CHOOO16 WITH THE OFFICE OF ENVIRONMENTAL ASSESSMENTS

OFFICE OF THE ASSISTANT SECRETARY FOR THE EKVIRONMENT UHITED STATES DEPARTMENT OF ENERGY 
ABSTRACT

Solid waste has become a subject of Increasing concern to energy industries for several reasons. Increasingly stringent air and water pollution regulations result in a larger fraction of residuals in the form of solid wastes. Control technologies, particularly flue gas desulfurization, can multiply the amount of waste. With the renewed emphasis on coal utilization and the likelihood of ofl shale development, increased amounts of solid waste w111 be produced.

In the past, solid waste residuals used for environmental assessment have tended only to include total quantities generated. To look at environmental impacts, however, data on the composition of the solid wastes are required.

Computer modules for calculating the quantities and composition of solid waste from major fossil fuel technologies were therefore developed and are described in this report. Six modules have been produced covering physical coal cleaning, conventional coal combustion with flue gas desulfurization, atmospheric fluidized-bed combustion, coal gasification using the Lurgi process, coal liquefaction using the SRC-II process, and ofl shale retorting.

Total quantities of each solid waste stream are computed together with the major components and a number of trace elements and radionuclides. 


\section{ACKNOWLEDGMENT}

We would like to acknowledge V. DeCar1o, the DOE Project officer, and assistance received from Teknekron Research, Inc. We thank the following people for their contributions: R. Meler for technical advice and coments from the formulation of the problem to the end product; $J$. Nagy for his assistance on the subject of radionuclides and for writing Section 7; and L. D. Hamilton for support, encouragement, and advice throughout the project. Finally, we are indebted to B. Burke, V. Crump, A. Link, M. L. Leist, S. Zuhoski, and S. Walch for support provided. 
Abstract $\ldots \ldots \ldots \ldots \ldots \ldots \ldots \ldots \ldots \ldots \ldots \ldots \ldots \ldots \ldots \ldots \ldots \ldots \ldots \ldots \ldots \ldots \ldots \ldots \ldots \ldots \ldots \ldots 11$

Acknowledgment $\ldots \ldots \ldots \ldots \ldots \ldots \ldots \ldots \ldots \ldots \ldots \ldots \ldots \ldots \ldots \ldots \ldots \ldots \ldots \ldots \ldots \ldots \ldots \ldots \ldots$ iv

Introduction $\ldots \ldots \ldots \ldots \ldots \ldots \ldots \ldots \ldots \ldots \ldots \ldots \ldots \ldots \ldots \ldots \ldots \ldots \ldots \ldots \ldots \ldots \ldots \ldots \ldots$

1. Solid Waste Module for Physical Coal Cleaning ................. 4

References .......................................... 31

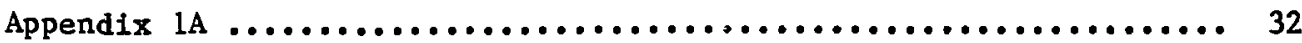

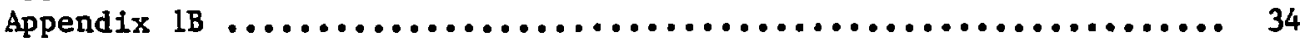

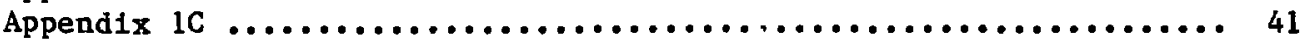

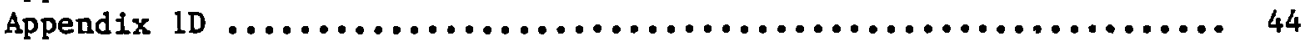

2. Solid Waste Module for Coal Combustion in a Conventional

Boiler ............................................... 54

References $\ldots \ldots \ldots \ldots \ldots \ldots \ldots \ldots \ldots \ldots \ldots \ldots \ldots \ldots \ldots \ldots \ldots \ldots \ldots \ldots \ldots \ldots \ldots \ldots \ldots 76$

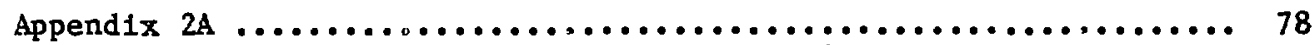

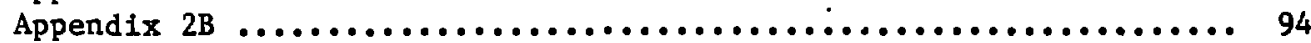

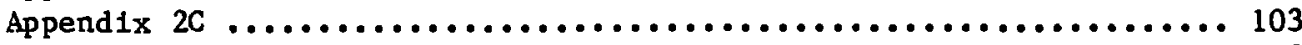

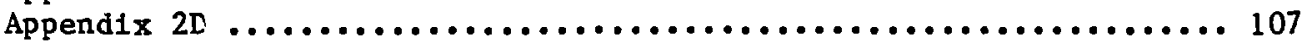

3. Solid Waste Module for Atmospheric Fluldized Bed Combustion ...... 118

References $\ldots \ldots \ldots \ldots \ldots \ldots \ldots \ldots \ldots \ldots \ldots \ldots \ldots \ldots \ldots \ldots \ldots \ldots \ldots \ldots \ldots \ldots \ldots \ldots \ldots 131$

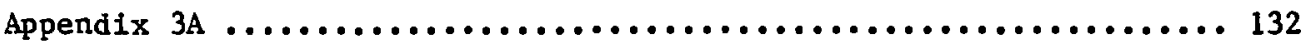

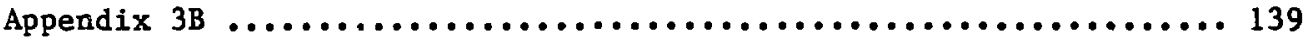

Append $1 x 3 C$........................................ 142

4. Solid Waste Module for Lurgi Process Coal Gasification............ 150

References .......................................... 164

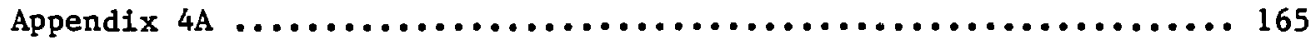

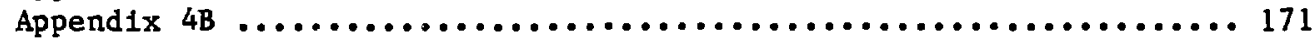

Appendix $4 C \ldots \ldots \ldots \ldots \ldots \ldots \ldots \ldots \ldots \ldots \ldots \ldots \ldots \ldots \ldots \ldots \ldots \ldots \ldots \ldots \ldots \ldots \ldots \ldots \ldots$

Appendix $4 \mathrm{D}$........................................ 180

5. Solld Waste Module for the SRC-II Process Coal Liquefaction ....... 186

References ........................................ 198

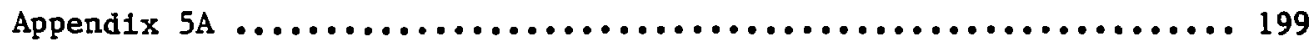

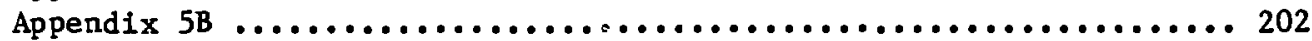

Appendix $5 C$........................................... 208

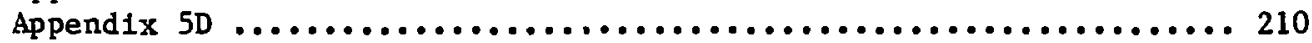

6. Solld Waste Module for 011 Shale Retorting .................. 216

References ........................................... 229

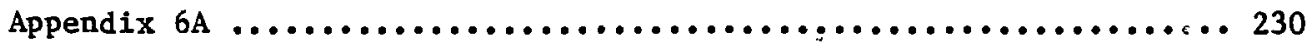

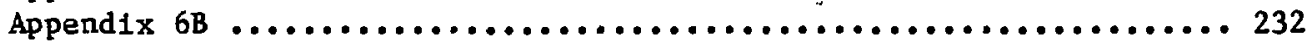

Appendix $6 \mathrm{C} \ldots \ldots \ldots \ldots \ldots \ldots \ldots \ldots \ldots \ldots \ldots \ldots \ldots \ldots \ldots \ldots \ldots \ldots \ldots \ldots \ldots \ldots \ldots \ldots \ldots . \ldots . \ldots \ldots \ldots$

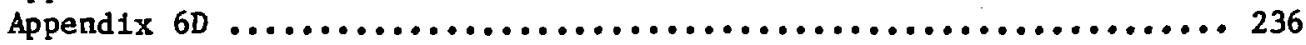

7. Radionuclides $\ldots \ldots \ldots \ldots \ldots \ldots \ldots \ldots \ldots \ldots \ldots \ldots \ldots \ldots \ldots \ldots \ldots \ldots \ldots \ldots \ldots \ldots \ldots \ldots$

References .......................................... 249 
1.1 Typical Size Distribution of Coals $\ldots \ldots \ldots \ldots \ldots \ldots \ldots \ldots \ldots \ldots$

$1.2 \quad$ Elements $\ldots \ldots \ldots \ldots \ldots \ldots \ldots \ldots \ldots \ldots \ldots \ldots \ldots \ldots \ldots \ldots \ldots \ldots \ldots \ldots \ldots \ldots \ldots . \ldots 22$

1.3 Coefficients Used to Determine Percentage Recovery of Trace Elements ................................... 28

1B.1 Example of Calculation of Fractionation Factor Using Results for Nickel ............................... 34

1 1B.2 Trace Metal Coal Cleaning Data ........................ 36

1B.3 Key to Trace Metal Factors ............................ 38

1B.4 Trace Element Recovery as a Function of Ash or Pyritic Sulfur Recovery .................................. 40

1D.1 Input Characteristics of Coal .......................... 44

$2.1 \quad$ Elements $\ldots \ldots \ldots \ldots \ldots \ldots \ldots \ldots \ldots \ldots \ldots \ldots \ldots \ldots \ldots \ldots \ldots \ldots \ldots \ldots \ldots \ldots \ldots$

2.2 Boller Coefflclents for Fraction of the Incoming Element

2.3 Coefficients for Calculation of Air Emissions ............. 66

2.4 Coefficients to Calculate the Function of a Trace Element Passing Through a Precipitator .................. 67

2.5 Coefficlents to Calculate FGD Sludge and Its Major Components for Wet Scrubbing Systems ................... 69

2.6 Eraction of Trace Elements in Lime and Limestone .......... 70

2.7 Coefficients to Calculate FGD Waste and Its Major Components for a Dry Sorbent Injection System ............. 74

2A.1 Fraction of Elements Entering with Coal Discharged in Bottom Ash or Slutce Ash for Sampled Stations ............. 79

2A.2 Fraction of Elements Entering with Coal Discharged in Economizer Ash Plus Scrubjer Slurry or Cyclone Ash or Precipitator Ash for Sampled Stations ................... 79

2A.3 Fraction of Elements Entering with Coal Discharged in F1ue Gas for Sampled Stations ........................ 80

2A. 4 Calculation of Average Percentage of Trace Elements which Remain in the Bottom Ash in a Pulverized Utility Boiler ..................................

2A.5 Distribution of Trace Elements for a Cyclone Botler Normalized to Give a Mass Balance of 100\%, Reference $5(1972)$................................

2A,6 Distribution of Trace Elements for a Cyclone Boller Normalized to Give a Mass Balance of $100 \%$, Reference 5 (1973) 
2A.7 Calculation of Average Percentage of Trace Elements which Remain in the Bottom Ash in a Cyclone

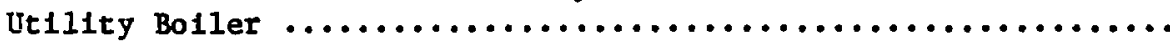

2A.8 Distribution of Trace Elements, Pulverized Boller, Station I, Reference 2, Using Average Boiler Fraction and Recalculating Fly Ash and Stack Gas ..................

2A.9 Distribution of Trace Elements, Pulverized Boiler, Station II, Reference 2, Using Average Boiler Fraction and Recalculating Fly Ash and Stack Gas ..................

2A.10 D1stribution of Trace Elements, Pulverized Boller, Station III, Reference 2, Using Average Boller Fraction

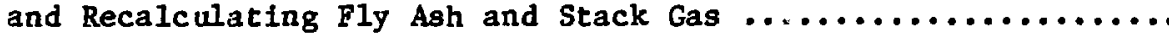

2A.11 Distribution of Trace Elements, Reference 5 (1972), Using Averzge Boiler Fraction and Recalculating Fly Ash and Stack Gas $\ldots \ldots \ldots \ldots \ldots \ldots \ldots \ldots \ldots \ldots \ldots \ldots \ldots \ldots \ldots \ldots \ldots \ldots$

2A.12 Distribution of Trace Elements, Reference 5 (1973), Using Average Boiler Fraction and Recalculating Fly Ash

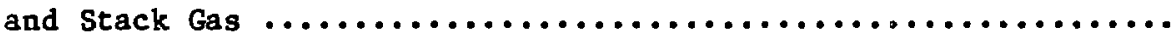

2A.13 Percentage Pass-Through of Trace Elements for Precipitators of Varying Efficlency ....................

2A.14 Enrichment of Trace Elements upon Passing through Precipltator ..................................

2A.15 Ratlos of Pass-Through of Trace Elements at Four Power Plants .....................................

2A.16 Theoretical Proportions of Trace Metal Pass-Through for Given Functions of Fly Ash Pass-Through ..................

2A.17 Relation of Particulate Pass-Through to Enriched Trace Element Pasis-Through for Enriched Trace Elements .............

2A.18 Percentage Pass-Through of Trace Elements as Compared to the Pass-Through of Fly Ash for a Scrubber.................

2B.1 Default Values for Calculation of FGD Solid Waste ........... 93

2B.2 Molecular Welghts of Compounds Used In FGD Systems ......... 95

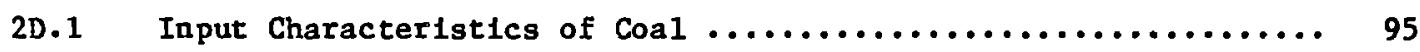

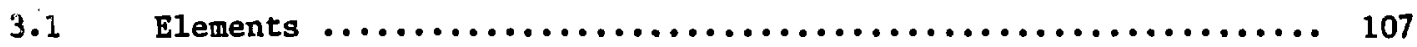

3.2 Composition of Spent Sorbent Material $\ldots \ldots \ldots \ldots \ldots \ldots \ldots \ldots \ldots \ldots \ldots$

3.3 Total Solid Waste Distribution ......................... 129

3.4 Coefficients for the Distribution of Elements Between

Output streams $\ldots \ldots \ldots \ldots \ldots \ldots \ldots \ldots \ldots \ldots \ldots \ldots \ldots \ldots \ldots \ldots \ldots \ldots \ldots \ldots \ldots$ 


\section{TABLES (Cont.)}

3C.1 Input Coal Charactaristics .......................... 143

$3 C .2$ Input Limestone Characteristics ........................ 143

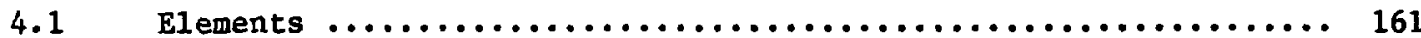

4.2 Fractions (Coefficlents) of Array Elements Going to Solld Waste Streams ............................... 162

4.3 Estimation of Water and Total Solid Waste ................. 163

4A.1 Coal Characteristics, Total Waste Streams, Water Content .................................. 166

4 A.2 Carbon Distribution ............................. 167

$4 A .3$ Sulfur Distribution $\ldots \ldots \ldots \ldots \ldots \ldots \ldots \ldots \ldots \ldots \ldots \ldots \ldots \ldots \ldots \ldots \ldots$

4 A.4 Ash Distribution .............................. 170

4B.1 Coal Content of Trace Elements (ppm) .................. 171

4B.2 Fraction of Input Trace Elements in Bottom Ash ............ 173

4B.3 Fraction of Input Trace Elements in $011 \ldots \ldots \ldots \ldots \ldots \ldots \ldots \ldots \ldots . . . . .174$

4B.4 Fraction of Input Trace Elements in $\operatorname{Tar} . \ldots \ldots \ldots \ldots \ldots \ldots \ldots \ldots$

4B.5 Fraction of Input Trace Elements in Gas Liquor ............. 176

4D.1 Input Characteristics of $\mathrm{Coal}$........................ 180

5.1 Summary of Solid Wastes Control Technology Applicabllity to SRC Systems .......................... 191

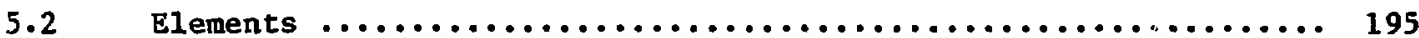

5.3 Fractions (Coefficlents) of Array Elements Going to Sol1d Waste Streams ............................... 196

5.4 Determination of Total Output and Ma for Components .......... 197

5B.1 Trace Element Content of "Average U.S. Coal" ............... 203

5B.2 Partitioning Factors and Proportion of Total Trace

Elements Retained in Mineral Residue .................... 205

5B.3 Trace Elements in Slag, Recovered Sulfur, and SRC

Product ....................................... 206

5D.1 Input Characteristics of Coal ........................ 210

6.1 Solld Weste other than Spent Shale $\ldots \ldots \ldots \ldots \ldots \ldots \ldots \ldots \ldots \ldots \ldots \ldots . . \ldots 22$

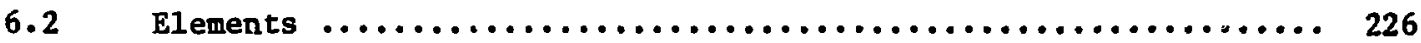

6.3 Coefficlents for Total Outprat and Major Components for

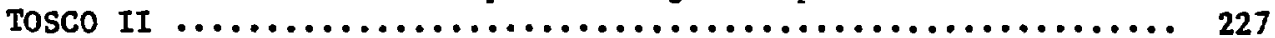

6.4 Coefficlents for Total Output and Major Components for Paraho .......................................... 227 


\section{TABLES (Cont.)}

6.5 Fractional Split of Trace Elements between Spent Shale and $011 \ldots \ldots \ldots \ldots \ldots \ldots \ldots \ldots \ldots \ldots \ldots \ldots \ldots \ldots \ldots \ldots \ldots \ldots \ldots \ldots \ldots \ldots \ldots \ldots$

$6 \mathrm{D} .1$ Input Characteristics of 011 shale .................... 236

7.1 Uranium Series Main Decay Chain (Minor Side Chains

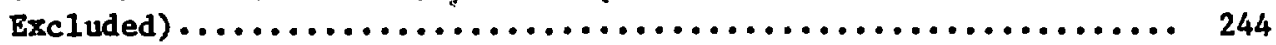

7.2 Actint un Series Main Decay Chain (Minor Side Chains

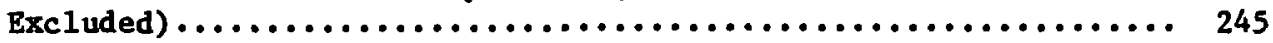

7.3 Thorium Series Main Decay Chain (Minor Side Chains Excluded)

\section{FIGURES}

$1.1 \quad$ Level 1 Preparation .................................. 10

1.2 Level 2 Preparation ................................ 12

$1.3 \quad$ Level 3 Preparation ................................ 16

1.4 Overall Coal Cleaning Module Design ..................... 21

2.1 Overall Conventional Combustion Module Design .............. 57

3.1 AFBC Conceptual Plant Design .......................... 120

3.2 Overall AFBC Module Design ............................ 125

4.1 Schematic Flow Diagram of a Coal Gasification Plant........... 153

5.1 Flow Diagram of a SRC-II Operation ..................... 188

5.2 Sources of Solid Wastes in SRC Systems..................... 192

6.1 Paraho Process .................................... 219

6.2 Tosco II Process ................................. 220

6.3 Overall 011 Shale Module Design ........................ 224 


\section{INTRODUCTION}

The Environmental Impacts Division, Office of Environmental Assessments, U.S. Department of Energy, has given Brookhaven National Laboratory the overall responsibility for developing a capability for assessing energy production solid waste problems and impacts. As part of this effort, the Biomedical and Environmental Assessment Division has developed six computer modules, in the form of FORTRAN subroutines, which can be used to estimate total solid waste and the composition of that waste for six fossil fuel technologies (coal combustion in a conventional boller, coal beneficlation, coal gasification, SRC-II process coal Iiquefaction, oil shale recovery, and atmospheric fluidized-bed combustion). These modules were written so that they could be used as individual programs for estimating solid waste in a single situation, or, could be included in a larger overall system of environmental assessment. In this report, each module is described and documented in detail. Computer codes and technical explanations of the calculations are appended to each section.

At present, in the Strategic Environmental Assessment System (SEAS), only the quantities of solld waste are calculated; no assessment is made of the composition of the waste either in terms of its major constituents or its trace element content. The composition of the waste is needed in order to determine disposal methods and potential environmental impacts. No estimation of the environmental impact of solid waste disposal is at present given in SEAS.

The Regional Studies Group at BNL is preparing an overall model to evaluate the impact of solid waste disposal from energy production. in 
important part of the model is the computation of the quantity and composition of the solid waste produced from different energy production processes. This w111 be achieved by a series of modules, each representing a specific technological process and producing information about the waste (amount and chemical composition) as a function of fuel input and, as needed, other information supplied exogenously to satisfy the requirements of the individual modules.

In an overall model framework such as these, the modules can be 1inked in series (e.g., coal beneficlation, coal combustion). Regulatory considerations are included in the main program; modules contain variables to simulate the technological response to changes in regulation. In an overall evaluation framework, regulatory and locai isnal considerations can be used in conjunction :. - h the coal input characteristics to specify emissions limits options in the technology modules. These considerations will also dictate the sequence of decisions which determines the management of the solid wastes (e.g., the regionally avallable method, need for full containment, etc.).

Since the modules will be used primarily in larger environmental assessment models such as those mentioned above, the individual modules used to compute the solid waste produced need to be mathematically simple so they may be called many times during a run of the overall program. Also, since at present the modules are data limited, they were written in such a way as to allow easy updating of coefficients when new data become available.

The modules are generally based on a mass balance approach and consist of one or more matrices of coefficients which, when multiplied by a vector of input fuel characteristics, results in a matrix describing the characteristics of one or more products and waste streams. The modules, however, remain a 
flexible means of coping with changes in air pollution control requirements, and in cases where there are various possible technologies (e.g., flue gas desulfurization (FGD) systems in conventional boiler coal combustion), they allow for a number of possible choices.

In many cases there is a linear relationship between the fuel characteristics and the residual characteristics for a specific technology. In those cases where this may not be the case, nonlinear functions are incorporated into the module.

Composition of the Solid Waste

The modules take run-of-mine (ROM) fossil fuel characterlstics and compute their fate during a combustion or conversion process. A choice had to be made as to which constituents should be considered.

For the major components, mass balances are calculated for sulfur, ash, and carbon. For the trace constituents, the trace elements listed by the EPA as toxic under the Clean Water Act were used (Federal Register, Vol. 44 , No. 191, Monday, October 1, 1979). In addition, 1ron, magnesium, and manganese were added.

The fui? 11st of trace elements considered is given below:

$\begin{array}{ll}\text { Antimony } & \text { Magnesium } \\ \text { Arsenic } & \text { Manganese } \\ \text { Beryllium } & \text { Mercury } \\ \text { Cadmium } & \text { Nickel } \\ \text { Chromium } & \text { Selenium } \\ \text { Copper } & \text { Silver }\end{array}$


Iron

Thallium

Lead

Zinc

Radionuclides are also important in describing solid waste, and the following were Included in the modules:

$\begin{array}{ll}\text { Uranium } & \text { Thorlum } \\ \text { Radium } & \text { Lead-210 }\end{array}$

The reasons for inclusion or exclusion of certain radionuclides are given in Section 7.

While the main purpose of the modules is to describe solid waste characteristics, the composition of product streams and air residuals is also Included in some of the modules.

Note: The results obtained by using the described computer modules should be considered only as good as the data used in determining the coefficients. As will be seen, data are often scarce and sometimes nonexistent. Some of the data used are suspect. Therefore, results should be regarded as only a general guideline to the actual composition of the solid waste from the fossil fuel technologies considered. In the future, it is hoped that more and better data will be collected so that the present coefficlents can be updated to improve the accuracy of estimation.

1 SOLID WASTE MODULE FOR PHYSICAL COAL CLEANING

\subsection{Introduction}

Physical coal preparation consists of the mechanical cleaning and sorting of particles of coal and its impurities. 


\subsubsection{Why Steam Coals Are Beneficiated}

Historically, only coals intended for metallurgical purposes were beneficlated to reduce their ash content. Steam coals were washed only when the raw coal, ROM, contained unacceptably high proportions of ash-forming minerals. Whereas power plants can often cope with ash contents of 20 percent or higher, some ROM coals contain up to 40 percent ash, and occasionally even more. When lower sulfur oxide emissions were mandated by the 1970 Clear Alr Act, coal beneficiation to reduce sulfur content gathered momentum. In light of the latest environmental developments, it is reasonable to expect ihat steam coal beneficlation will become increasingly important as; a major B\&CT (Best Available Control Technology) and will be used with flue gas cleanup systems to meet increasingly strict sulfur controls. In other cases, coal beneficiation willpay for itself because the enrichment of the shipped product reduces freight costs.

\subsubsection{Coal Beneficiation Principles}

With few exceptions, all washed coals are processed in water or water-based medla, using gravity methods which rely on the differences in specific gravity between the coal and minerals mixed therewith. Only extraneous impurities are separable from the coal proper, although the efficlency o? such separation varies with the coal's characteristics.

A jig, the most popular coal-washing device, uses differential setting or induced stratification to separate the lighter coal from the heavie: ash-forming minerals. Next in popularity is the heavy-uedia process. With this method, the coal is floated in a water-based medium of controlled specific gravity and the heavier minerais are permitted to sink and be removed 
as rejects. The concentrating table separates coal from rejects by stratification induced by vibration. Cyclones, either water-only or heavy-media types, supplement gravity by centrifugal force to make sharper separations than static vessels. Froth flotation, which is used with coal particles smallar than 28 mesh ( $1 / 2$ millimeter), uses chemical reagents to form air bubbles which selectively attach themselves to the coal while permitting the ash to settle to the bottom.

Because any coal particle contains both coal and ash, its spectfic gravity will depend on the relative percentages of each. Pure coal has a specific gravity slightly less than 1.3, whereas a dirty coal containing approximately $60 \%$ ash has a specific gravity of about 1.8. Most clean coals are produced with specific gravities between 1.4 and 1.6 and contain upward of $5 \%$ ash. The smaller the particle's size, the better the chance of separating the coal from its ash but also the higher the procesing costs. As pyritic sulfur is assoclated with ash and has an even greater specific gravity, sulfur reduction methods are essentially the same as those used for ash reduction and are subject to the sane limitations.

\subsubsection{Levels of Coal Preparation}

The extent of the work done on raw cual is determined by marketing considerations and by the results of float-sink tests called coal washability analyses. There are substantial differences in the degree to which any coal can be improved by beneficiation. In the past it was primarily the ash content of a coal which had to be limited, and the smallest amount of preparation to meet that criterion was used. Since the advent of the Clean Alr Act, more steam coal specifications call for quallty products achievable 
only through beneficiation. Costs associated with coal beneficiation reflect the level of preparation practiced. Obviously, crushing only to control top size is far less costly than beneficlation to reduce ash and sulfur content. Goal preparation can be classified according to the sizes of coal particles processed. The smaller the particles, the more rigorous the level of beneficiation, the more complex and costly the process, and the better the product.

Coal preparation processes are usually designed and operated for site specific applications. Plants can be loosely grouped as jig plants, table plants, and heavy media plants. As plants frequently use at least two, if not all three, of these methods simultaneously and at times flotation, this classification has limited usefulness. Professor H. Lovell of Pennsylvania State University defines four levels of preparation. At one end, level 1 employs no preparation at all, while at the other end, level 4 calls for multistage beneficiation. Gibbs and Hill Inc. $t r i$ a report prepared for EPRI 2 proposes that at least $\mathrm{six}$ levels are required to represent the most basic differences:

Level $0:$ Absence of preparation indicates that the coal is shipped as mined.

Leve1 1: Breaking for top size control only, with limited, if any, removal of coarse refuse and trash.

Level 2: Coarse beneficlation through washing of $>3 / 8-1$. material only: 3/8-in. $x$ fraction remains dry and is recombined with the clean coal prior to shipment. 
Level 3: Deliberate beneficlation through washing of all $>28$ mesh material; 28-mesh $\times 0$ material, depending on its quality, is either dewatered and shipped with clean coal or discarded with the refuse.

Leve1 4: Elaborate beneficiation through washing of all size fractions, including 28 mesh $\times 0$. Thermal drying of $1 / 4-1 n$. $x \quad 0$ sizes is generally required to limit moisture content.

Level 5: Full beneficiation implies the most rigorous coal beneficlation.

At present, levels 1 and 2 are used to clean steam coal and levels 4 and 5 are used for metallurgical coal.

Level 3 improves the quality of the coal over that of level 2 by cleaning the 1/4-in. $\times 28$-mesh size which normally contains large amounts of sulfur.

The present module will allow the calculation of solid waste for coal cleaned at levels 1 to 3 . If in the future it is felt the utilities nay use coal thrt has been beneficlated to metallurgical standards, levels 4 and 5 could be added. However, the module will become more complicated and da: $=$ restrictive as the level of cleaning increases, particularly since levels 4 and 5 would require thermal drying of the coals.

Each of the three levels to be employed in the module is discussed in greater detall below. 
Preparation Level 1 - Breaking Only

Block Diagram: Figure 1.1 .

Scope: Top size control through crushing only prior to storage and/or shipment. In this context, level 1 preparation does not include physical coal preparation processes such as crushing, grinding, classifying, slurrying and dewatering, compacting, and pelletizing.

Purpose and Benefits: Except for the relatively few mines able to ship ROM coal directly to the user, most mines must control the top size of the raw coal to facllitate handling and to suit customer requirements. Normally there is little 1mprovement in coal quality as a result of crushing the coal prior to shipment, except possibly in northern West Virginia, and in parts of Ohio, Pennsylvania, and Illinols, where large formations of pyritic sulfur are sometimes encountered. Unless removed by a rotary breaker, these very hard lumps can damage crushers. Wood and timber can also be removed from the ROM feed by a rotary breaker.

Ash Reduction: Negligible.

Suliur Reduction: Negliglbie.

Yleld - Welght Basis: 98 to $100 \%$

Recovery - Btu Basis: 99 to $100 \%$.

Major Circuits and Equipment Used: Size reduction is accomplished by means of crushers and/or rotary breakers. Scalping screens (coarse screens) are frequently used ahead of crushers and breakers either to remove large wood and timbers likely to plug the crushers or to bypass the crushers with coal particles already small enough. Breakers work 


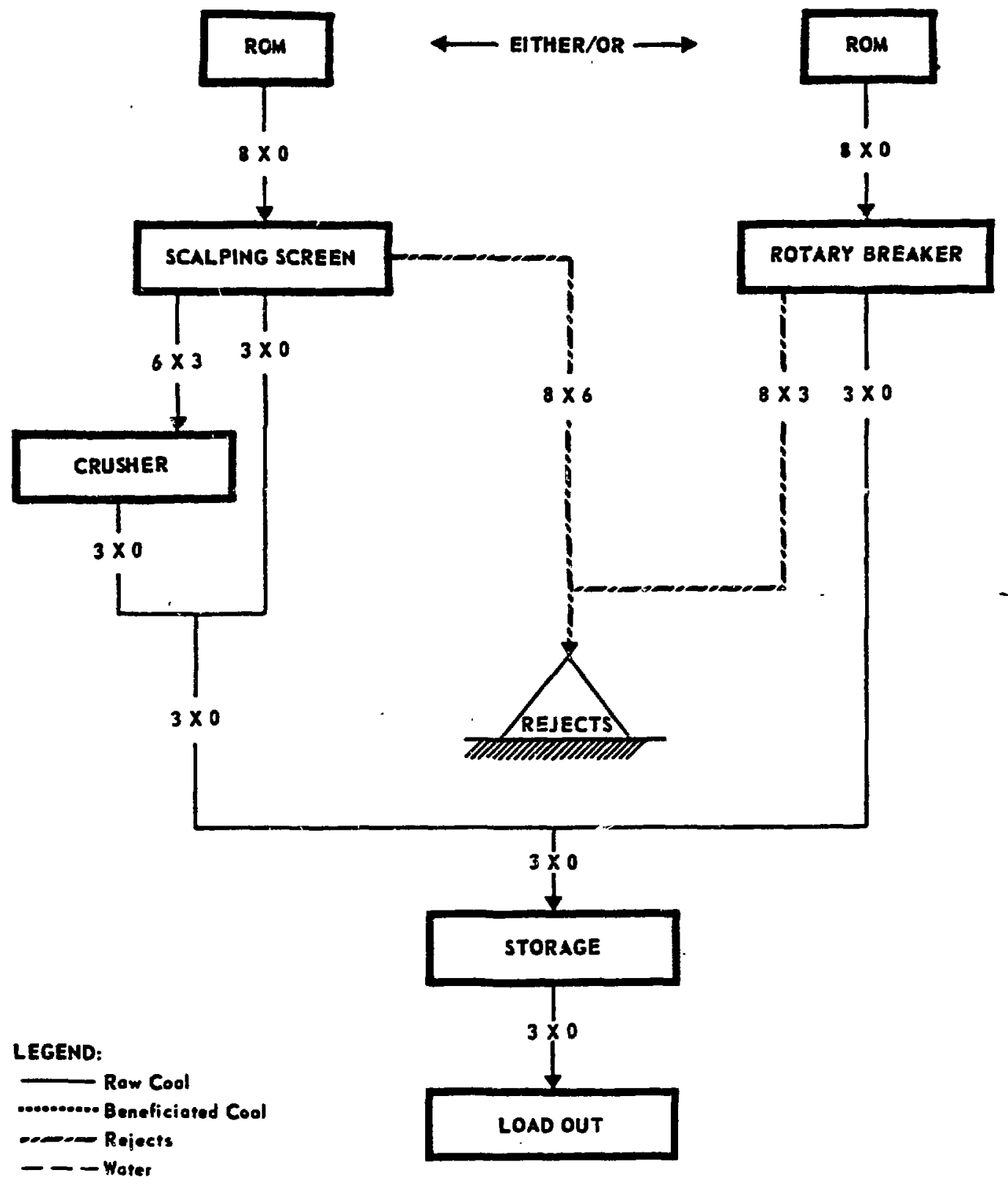

Figure 1.1. Level 1 preparation. (From Reference 2.) 
when the coal is soft and the rock is hard because they size and recover all coal and reject large rock, wood, timber, and trash.

When the coal is hard or tough, single or double roll crushers are used, preceded by scalping screens. Where ROM coal is relatively clean and where wood and timbers are no problem, rotary breakers are sometimes sealed, preventing discharge of rejects. In this way they act like single roll crushers but their maintenance costs are lower.

Strlp-rnined subbituminous coals and lignites are reduced in size by means of roll crushers when trash is not a problem. Breakers are used when seams are contaminated with rocks or petrified wood.

Rejects Processing and Disposal: Disposal is usually by truck to the mine refuse area where it is layered and compacted by a bulldozer at the head of the valley. This material is usually dry and coarse. Thus, drainage and seepage are not a problem nor is spontaneous combustion.

\section{Preparation Level 2 - Coarse Beneflctation}

Block Diagram: Figure 1.2.

Scope: After level 1 preparation, renove the 3/8-in. $x$ particles by dry screening. Wet beneficiate only the $>3 / 8-1 n$. coal, then dewater by mechanical means and ship after recombining with the unprocessed 3/8-in. $x$ raw coal fines. Where raw coals do not contain excess surface moisture (because of dust control sprays at mine face) likely to plug the screen openings, dry screening at $1 / 4$ in. is preferred.

Purpose and Benefits: Coarse beneficiation removes the coarse impurities (above $3 / 8$ in.) often found within coal seams, such as partings and the 


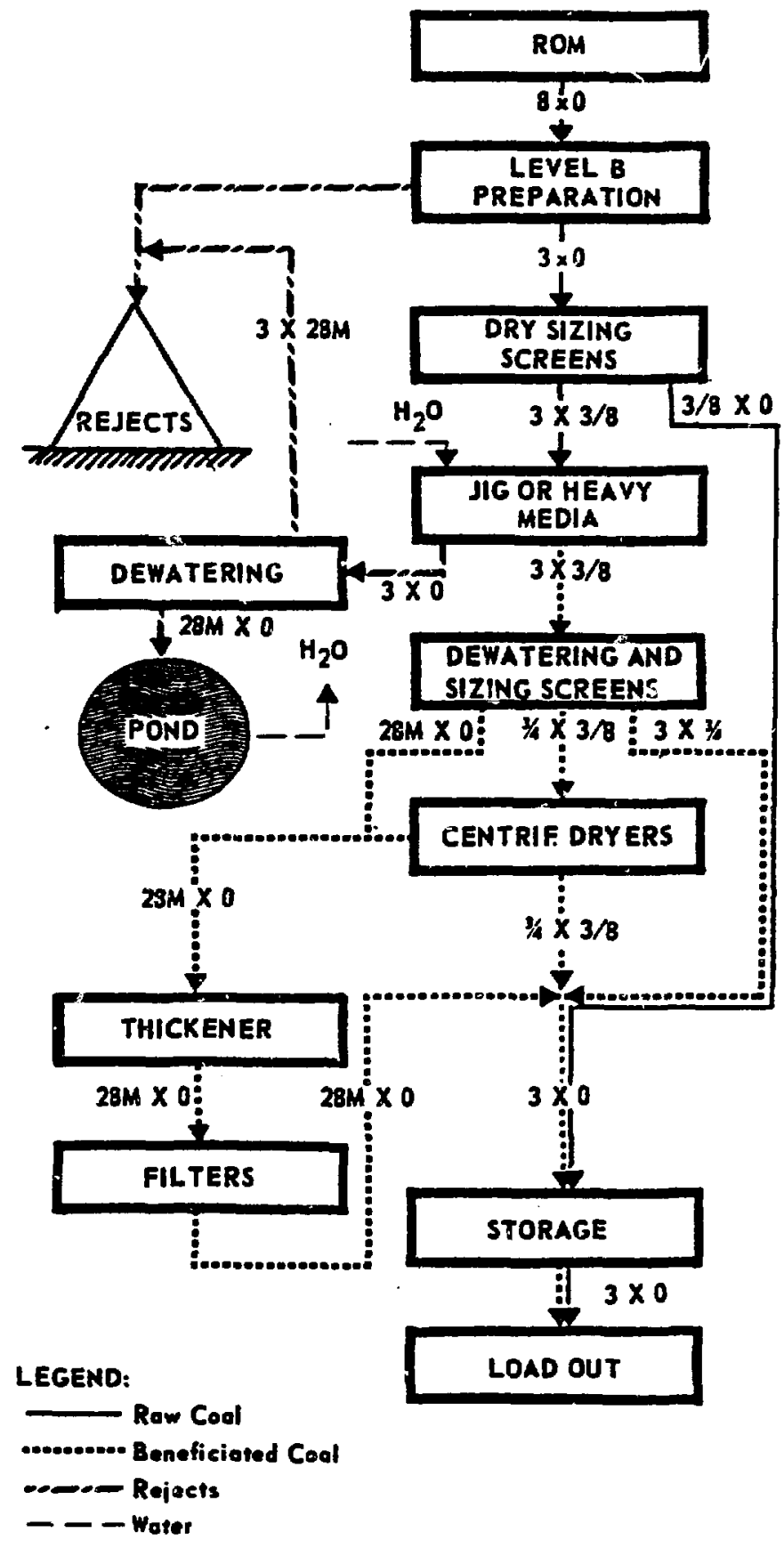

Figure 1.2. Leve1 2 preparation. (From Reference 2.) 
extraneous material (roof and bottom) extracted with the coal as a result of big production mining procedures. The $3 / 8-1 \mathrm{n}$. $x$ raw coal split remalns as mined and rejoins the clean coal stream prior to shipment. Although coarse beneficiation can remove substantial quantities of extraneous matter which would otherwise show up in ash analysis of the coals, substantial sulfur reduction should not be expected as sulfur particles are generajily not associated with the coarse rejects. Coarse beneficiation of steam coals is practiced on coals from Appalachia and Alabama which have excellent washability characteristics and where the ash content of the coal fines is not excessive. 28-mesh $x 0$ coal from an Appalachian seam, for example, contalns less than 22\%ash, whereas the same split from an Illinois seam might run up to $40 \%$ ash.

Ash Reduction: Fair to good; can compensate for poor quality control at the mine face,

Sulfur Reduction: Minor as the coarse rejects rarely contain much sulfur.

Iield - Weight Basis: 75 to $85 \%$.

Recovery - Btu Basis: 9n to 95\%; Btu recovery is good because few of the coarse rejects, except bone coal, contain many Btu.

Mifor Circults and Equipment Used: ROM coal is first reduced in a level 1 circuit to < $3 \mathrm{in.}$ ( $3 \mathrm{in}$. Is used as an example). Further reductions to $3 / 4 \mathrm{in}$, or less may be more deglrable, but each coal must be evaluated individually. Crushed coal is then dry screened at $3 / 8$ in. to remove the 
fines which bypass the beneficlation circults and eventually rejoln the washed coal.

The $>3 / 8$ in. fraction is beneflclated in jigs or heavy media vessels at a relatively high speciflc gravity ( 1.50 to 1.55$)$ to reduce the amount of coal included with the rejects (refuse). The clean coal fraction is then passed over dewatering and sizing screens. The coarsest fraction ( $>3 / 4$ 1n.) contains relatively little surface molsture and can be shipped without further treatment. The 3/4-in. x 3/8-in. split must be dewatered in mechanical dryers, while the limited amount of 28 -mesh $x 0$ washed from the clean coal discharges either to a thlckener and filters or to a settling pond. The clean coal, combining the 3/8-1n. $x$ dry screened fraction, the >3/8-in. washed fraction, and the 28-mesh $x \quad 0$ filter product may contain slightly more surface molstura than the ROM coal, but not enough to cause transportation or utilization problems.

Rejects Processirg and Disposal: The dry refuse from level 2 can be discarded as discussed earlier. The rejects from jigs or heavy-media vessels consist of wet, $>3 / 8-1$. refuse and a $<28-m e s h$ slurrz. The slurry is either discharged to a settling pond or reports to a thickener for water clarification and recovery. If a thickener is used, the underflow (water and suspended solids) might have to be ponded. Because of regulatory regtrictions on the use of ponds and impoundments, their use is decreasing in favor of centrifuging and filtering. The $>3 / 8$ in. refects may contain from 6 to $12 \%$ surface molsture, depending on top size. This refuse, which can represent 15 to $40 \%$ of the raw coal, must be transported tc, and confined within, a suitable disposal area 
constructed, operated, and malntalned in accordance with applicable regulations.

\section{Preparation Level 3 - Deliberate Beneficlation}

Block Diagram: Figure 1.3 .

Scope: After level 1 preparation, the 3/8-in. $x 0$ particles from the 31n. $x \quad 0$ feed are separated by wet screenting, followed by a second separation at 28 mesh. The $>3 / 8 \mathrm{in}$. coal is washed as in level 2 . The 3/8-1n. $x$ 28-mesh is beneficlated on concentrating tables or in heavymedia cyclones, followed by dewatering screens and centrifugal driers. The 28-mesh $x 0$ split is combined with the same size produst from other circuits and, although not beneficiated, is thickened and filtered prior to rejolning the clean coal stream for shipment.

Purpose and Benef1ts: Level 3 coal preparation further improves quality by beneficiating the 3/8-1n. x 28-mesh size which normally contalns large amounts of ash and sulfur. As this fraction may roughly constitute one third of the plant feed, the quality of the clean coal will favorably reflect the work done on the $3 / 8-1$. $x$ 28-mesh split.

Ash Reduction: Good to excellent.

Sulfur Reduction: Falr to good.

Yleld - Welght Basts: 60 to $80 \%$.

Recovery - Btu Basis: 80 to $90 \%$; as the finer coal sizes are nore difficult to beneficlate, the percentage recovery decreases in comparison with level 2 . 


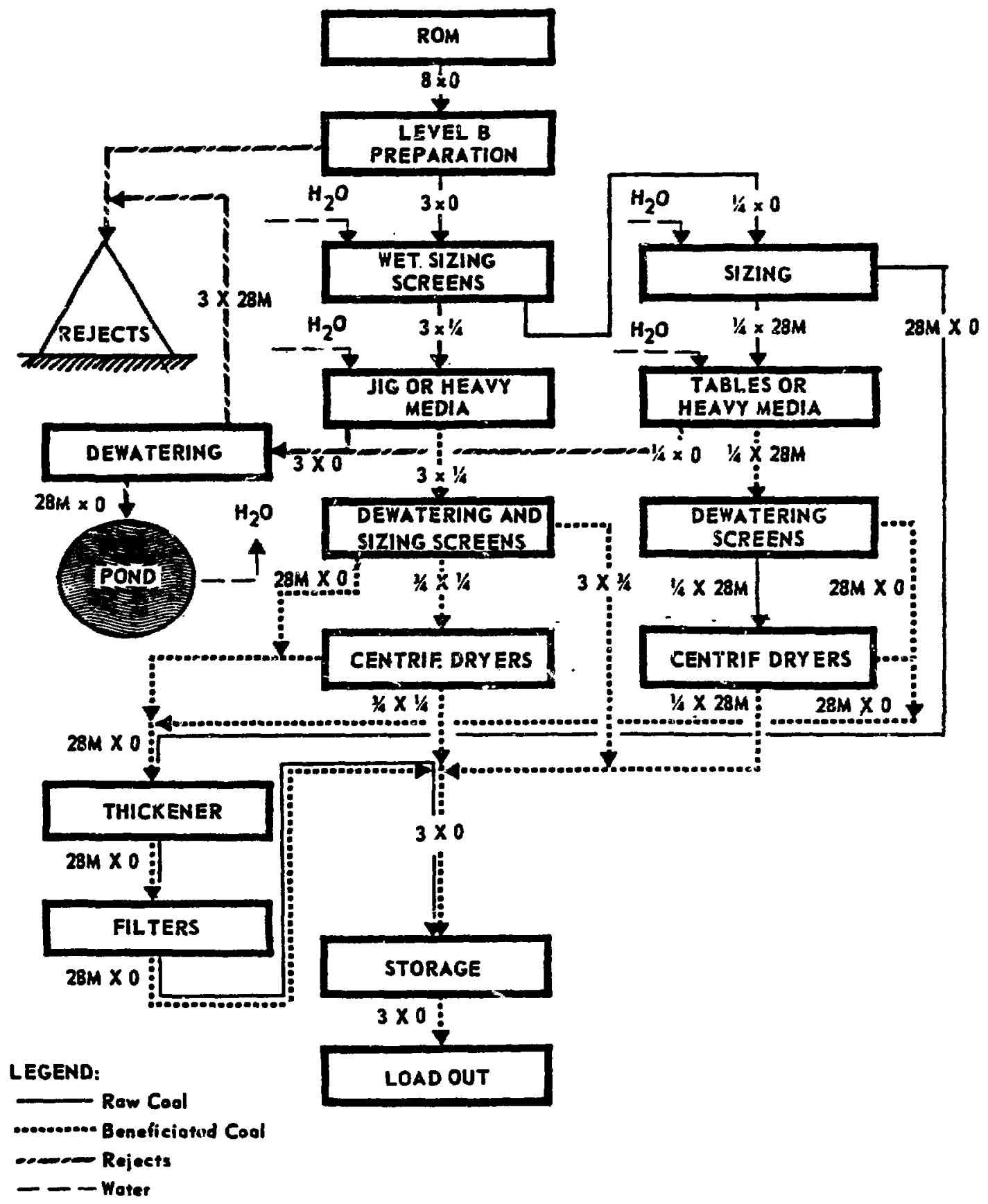

Figure 1.3 Leve1 3 preparation. (From Reference 2.) 
Major Circuits and Equipment Used: The circults are those required for a level 2 plant, plus those for beneficiating the $3 / 8-i n \cdot x 28$-mesh coal. Concentrating tables or heavy-media cyclones are suitable, followed by mechanical dewatering. Thickeners and filters, preceded by classifying cyclones, are used when the <28-mesh percentage is high and are used both for the clean coal and the rejects when ponding is unavallable.

Rejects Processing and Disposal: Problems encountered with rejects from level 2 plants are accentuated in level 3 plants which must dispose of even greater amounts of wetted fines, particularly the 28-mesh $x \quad 0$ fraction. When the $<28$ mesh slurry contains clay (southern Iilinols strip mines, for example), it must be pumped to impoundment areas, as filters cannot efficiently handle clays. Legal restrictions on such impoundments someitimes effectively prohibit their use or at least increase their construction costs. Dams costing several million dollars are not unheard of. In flat terrain, the problem may be practically insurmoutable because of the large quantities involved. The 3/8-in. $x$ 28-mesh refuse contains 17 to $22 \%$ moisture, depending on dewatering methods employed and the 28-mesh $x \quad 0$ fraction, after filtering, will contain 15 to $25 \%$ moisture. The $3 / 8-1 n$. $x$ rejects pose handling problems, not only during freezing temperatures but also at other times because such refuse is difficult to convey or truck without spills or leaks. Disposal is complicated by detalled regulations Including prohibition on effluent. 


\section{1 .4 Modeling Problems}

Coal preparation is very site specific; every plant is built differently because of the large variation in the washability of different coals. This causes a number of problems when trying to bulld a model which will have to deal with cleaning in a general manner.

A brief description of the major problems encountered and the methods used to overcome them is given below.

Pyritic Sulfur and Ash Removal. Given a specified level of cleaning, the amount of pyritic sulfur removed will vary with each coal sample (variations may be found even within the same coal bed). To a lesser degree, this is also true of ash removal.

The U.S. Bureau of Mines $^{3}$ has performed washability studies on 455 samples of coal. These results were used to determine if it was possible to correlate pyritic sulfur with ash removal, Btu loss, and overall material 1oss. Details are given in Appendix $1 \mathrm{~A}$.

Trace Metal Removal. As with pyritic sulfur, the removal of trace metals will also vary, depending on the coal type used.

Data from a number of float sink tests which looked at the fate of trace metals were used to determine if a function could be found which related trace metal removal with pyritic sulfur or ash removal. Details are given in Appendix 1B.

Size Distribution of the Coal. As can be seen from the block diagrams, the amount of coal cleaned at each level and hence the amount of solid waste will depend on the size distribution of the coal after crushing. 
Although the slze distribution is not a haphazard event, the equations used to calculate the distribution require constants which vary for each coal type and depend on such properties as the frlability of the coal. Distributions cannot be calculated in the module and therefore a number of typical size distributions were examined and the average taken (Table 1.1).

Table 1.1

Typical Size Distribution of Coals

\begin{tabular}{lccc}
\hline & $>3 / 8$ in. & $3 / 8$ 1n. -28 mesh & $<28$ mesh \\
\hline Reference 4 & 72.0 & 28.0 & \\
\hline Nat. ave. steam cleaning & 53.2 & 40.0 & 6.8 \\
Nat. ave. metallurgical cleaning & 56.0 & 44.0 & \\
Central region ave. & 72.0 & 28.0 & \\
Northern Appalacian region & & & 4.0 \\
Reference 5 & 77.0 & 34.0 & 6.0 \\
Freeport, Pennsylvania & 60.0 & 34.0 & 6.0 \\
Crushed Freeport, Pennsylvania & 70.0 & & \\
Roslyn bed, Washington & 60.0 & 23.0 & 7.0 \\
Alabama & & 27.8 & 6.0 \\
Reference 2 & 70.0 & & \\
Alabama & 65.6 & & \\
Average & & & \\
\hline
\end{tabular}

The module assunes the following split:

$$
\begin{array}{lr}
>3 / 8 \text { In. } & 66 \% \\
3 / 8 \text { 1n }-28 \text { mesh } & 28 \% \\
<28 \text { mesh } & 6 \%
\end{array}
$$

\subsection{Coal Cleaning Module Description}

\subsubsection{General Description}

The module computes the solid waste residuals and the clean coal characteristics which result from physical coal cleaning at three levels of intensity. 
The input to the module 1 s the quantity of coal and its composition in terms of sulfur (pyritic and organic), ash, trace elements, and Btu content.. The module employs a mass balance approach to compute the distribution of the sulfur, ash, and trace elements between the clean coal and the solld waste refuse. Figure 1.4 gives an overall view of the module.

For levels 2 and 3 , the equations used to compute the solld waste produced are valid only when the input ash content of the coal exceeds $6.25 \%$. This is thought to be reasonable since it is unlikely that it would be economical to try to clean a coal with a lower ash content. Iow ash coals normal1y have low sulfur contents.

Since thermal drying is not being considered, the only air emissions are fugitive dusts, which are difficult to quantify. No air emission estimates are therefore included.

The module is called as a subroutine with the following argunents:

Input vector of coai characteristics.

Output vector of clean coal composition.

Output vector of solid waste composition.

Input quantity of coal/output quantity of coal.

Level of coal preparation. Input integer number from 1 to 3 .

To facilitate computation, the first three arguments are vectors which :ontain the same number of elements. The elements are shown in Table 1.2. Since these vectors are constructed to be conformable to any of the solid waste modules which have been produced, there are presently some empty elements ( 48 to 50, not shown in Table 1.2) and some elements which are not applicable to this module and are disregarded (set to 0 ) in the output vectors and omitted in the output printout. 

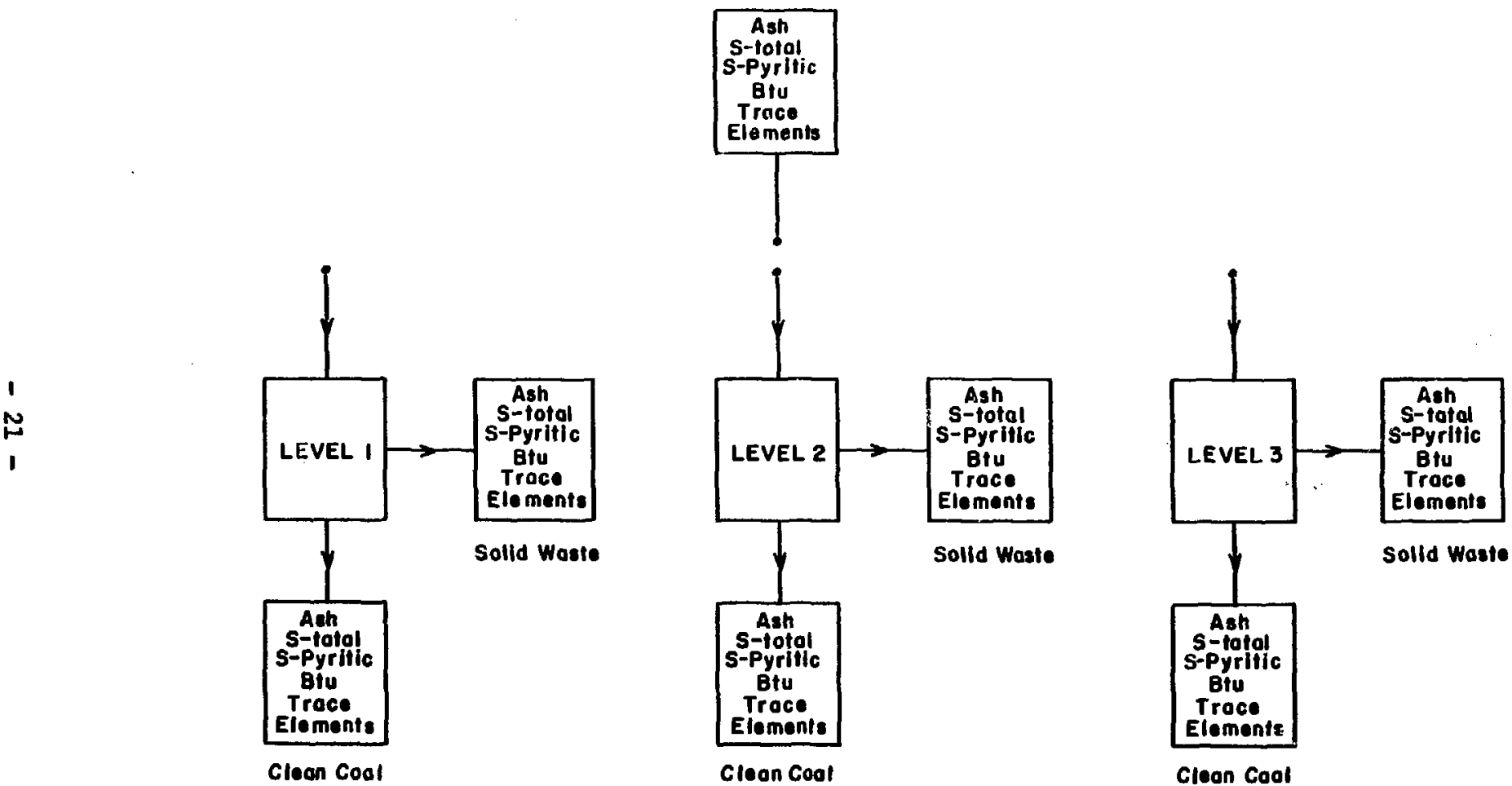

Figure 1.4. Overall coal cleaning module degign. 


\begin{tabular}{|c|c|c|c|}
\hline \multicolumn{4}{|c|}{$\begin{array}{l}\text { Table } 1.2 \\
\text { Elements }\end{array}$} \\
\hline Number & Type & Number & Type \\
\hline 1 & Ash & 24 & Hydrocarbons \\
\hline 2 & Sulfur (S) & 25 & Total solid waste \\
\hline 3 & Antimony (Sb) & 26 & Unreacted Iimestone \\
\hline 4 & Arsentc (As) & 27 & Calciun sulfite \\
\hline 5 & Beryll1um (Be) & 28 & Calcium sulfate \\
\hline 6 & Cadmi un (Cd) & 29 & Soda ash \\
\hline 7 & Chromiun (Cr) & 30 & Magnesiun sulfite \\
\hline 8 & Copper (Cu) & 31 & Magnesi un oxide \\
\hline 9 & Iron ( $\mathrm{Fe}$ ) & 32 & Sodiun bisulfite \\
\hline 10 & Lead ( $\mathrm{Pb})$ & 33 & Sodium sulfite \\
\hline 11 & Magnesi um (Mg) & 34 & Water \\
\hline 12 & Manganese (Mn) & 35 & Sulfur dioxide \\
\hline 13 & Mercury (Hg) & 36 & Nitrous oxides \\
\hline 14 & Nickel (Ni) & 37 & Carbon monoxide \\
\hline 15 & Selenitu (Se) & 38 & Methane \\
\hline 16 & Silver (Ag) & 39 & Pyritic sulfur \\
\hline 17 & Tha11 in (T1) & 40 & Carbon \\
\hline 18 & Zinc $(\mathrm{Zn})$ & 41 & Btu \\
\hline 19 & Uranium-238 (U) & 42 & Carbon dioxide \\
\hline 20 & Thori um-232 (Th) & 43 & Sodium bicarbonate \\
\hline 21 & Radium-226 (Ra) & 44 & Sodium carbonate \\
\hline 22 & Radi um-228 (Ra) & 45 & Sodfun sulfate \\
\hline \multirow[t]{2}{*}{23} & Lead-210 (Pb) & 46 & Calcium carbonate \\
\hline & & 47 & Calcium oxide \\
\hline
\end{tabular}


Data are, at present, only generally avallable for the input quantities of urantum and thor 1 um. However, the masses of radium-226 and lead-210 can be calculated from the mass of uranium-238 and the mass of radium-228 from thortum-232. The equations and assumptions used in the calculation are given In Section 7 .

It is assumed for each level of cleaning that the percentage carbon reduction is equivalent to the percentage Btu loss.

For each level of cleaning, there will be an output vector of clean coal characteristics and of solid waste quantity and composition. Also given is the output quantity of clean coal. The total Btu's in the clean coal are given In the output clean coal vector and therefore the new $\mathrm{Btu} / \mathrm{lb}$ can be calculated, if required, for further analysis.

\subsubsection{Leve1 1 Cleaning}

The module assumes a $99.5 \%$ Btu recovery and a $98 \%$ material recovery. These are average figures from References 2, 4, and 6 .

The solld waste will therefore contain $0.5 \%$ of the input carbon. The fraction of the ash removed can then be calculated using the following equation:

$$
\text { ASHREM }=(0.02 \times \text { COAL })-(0.005 \times \text { CARBON }) /(\text { COAL-CARBON }),
$$

where

$$
\begin{aligned}
& \text { ASHREM is the fraction of incoming ash removed, } \\
& \text { COAL is the total quantity of input coal, } \\
& \text { CARBON is the input quantity of carbon. }
\end{aligned}
$$

With the exception of sulfur, the same removal fraction as ash is used for the other trace elements. 
The pyritic sulfur is assumed to be reduced by the same amount as the ash, but the organic sulfur is removed at the same rate as the carbon. Organic sulfur is not given as a separate input element but is calculated as the difference between the total and pyritic sulfur.

There are two output vectors to describe the clean coal and solid waste composition. The total solid waste (element 25) is assumed to be a dry welght.

\subsubsection{Level 2 cleaning}

The module assumes an overall Btu recovery of $93 \%$ (average value from references 2,4 , and 6 ). However, only the $>3 / 8-1$. fraction of the coal is belng cleaned. This constitutes $66 \%$ of the input coal (see section 1.4 .4 ) and therefore the Btu recovery for the coal subject to cleaning is $89.4 \%$.

Major Components. The major components of the solid waste are carbon, sulfur, and ash.

Physical cleaning removes only pyritic sulfur. However, since there is some carbon removal it is assumed that there will also be a small reduction in organic sulfur.

The major components of the waste are calculated using the following equations. Those for total waste and pyritic sulfur were derived from the results of the washability studies performed by the Bureau of Mines.3 Details on how the equations were derived are given in Appendix 1A. These equations are applied to only $66 \%$ of the incoming coal.

$$
\begin{aligned}
\text { Total Solld Waste } & \text { (Dry Welght) } \\
\text { COALR } & =0.719 \times A+0.890 \times \text { BTUR }-3.698 \\
\text { TSW } & =\text { QCOAL } \times(\text { COALR } / 100),
\end{aligned}
$$


where

COALR is the percentage material removal,

A is the ash content of input coal (\%),

BTUR is the percentage Btu removal,

TSW is the total quantity of solld waste,

QCOAL Is the Input coal quantity.

Carbon Content of Solld Waste

where

$\mathrm{CSW}=\mathrm{QC} \times(\mathrm{BTUR} / 100)$,

CSW is the quantity of carbon in the waste,

QC is the input quantity of carbon.

Hydrogen, Oxygen and Nitrogen Content of the Solld Waste. Although hydrogen, oxygen, and nitrogen are not considered as elements in the module, their presence in the coal affects the amount of ash in the solid waste. They are assumed to be present in the solid waste in the same proportion as the carbon removal.

where

OHNSW $=(Q C O A L-Q C-Q A-Q S) \times(B T U R / 100)$,

OHNSW is the total quantity of hydrogen, nitrogen, and oxygen in the solid waste,

QA Is the input ash quantity,

QS is the input sulfur quantity.

Ash Content of Solid Waste

where

$A S W=T S W-$ CSW - OHNSW,

ASW is the amount of ash in the solid waste. 
Sulfur Content of Solid Waste

Organic Sulfur

where

OSSW $=$ QOS $\times($ BTUR/100),

OSSW is the quantity of organic sulfur in the solid waste,

QOS is the quantity of organic sulfur in the input coal.

\section{Pyritic Sulfur}

$$
\begin{aligned}
& \mathrm{PSR}=0.686 \mathrm{AR}+3.578 \mathrm{Ln}(\mathrm{PS})+2.499 \mathrm{BTUR} \\
& +127.286 \operatorname{Ln}(100-\text { COALR })-584.565 \text {, } \\
& \text { PSSW = QPS x (PSR/100), }
\end{aligned}
$$

\section{Total sulfur}

where

$$
\text { SSW }=\text { OSSW + PSSW tons, }
$$

SSW is the total quantity of sulfur in the solid waste.

Trace Components. A number of workers have performed float-sink tests on coal samples to determine the fate of trace elements during washirg.

H,J. Gluskoter and his colleagues have investigated the trace element content of coal for the Illinols State Geological Survey. In Fieference 7, nine coal samples were crushed to 3/8-in. top size and the 3/8-1n. x 28-mesh fraction was subjected to specific gravity separation. One set of samples had very poor mass balances and contalned some spurfous results; the data for one set were incomplete so the results from 7 samples were used in this analysis. 
C.T. Ford of the BItuminous Coal Research Institute has recently been studying the effect of washing on the trace element content of coal. Unfortunately, the only results now available are from a symposium held in $1977^{8}$, but a report is being compiled which will give more recent results. Reference 8 describes specific gravity separations performed on 8 samples using the $3 / 8-1$. $x 0$ size.

These two sets of experiments examined a large number of trace elements. Two further reports were used but in these only a limited range of trace elements were measured. J.A. Cavallaro and colleagues 9 at the Bureau of Mines reported on the results for specific gravity separation of 14-mesh top size samples of 10 coals; in another report 10 they look at 4 samples again crushed to 14-mesh top size:

The results were used to calculate the fraction of each trace element that remained with the clean coal. The fractions were normalized to assume a $100 \%$ coal recovery level. Details of how the fractionation factors were calculated are given in Appendix 1B.

These figures were used to determine whether there was any correlation between the recovery of a particular trace element and the recovery of pyritic sulfur or ash. In many cases, equations could be found which gave the recovery of a trace element as a function of the ash or pyritic sulfur recovery. In some cases, no correlation was found and an average value is used.

Table 1.3 gives the coefficients used to determine the recovery of trace elements; details of how they were obtained are given 1n Appendix 1B. Again, these coefficients are applied to $66 \%$ of the coal. 
Table 1.3

Coefficients Used To Determine Percentage Rscovery of Trace Elements

Element

Coefficlent (\% Recovery)

Antimony

85.0

Arsenic

A

Bery111 un

$4.641 \sqrt{\mathrm{A}}+49.713$

Cadmi un

Ln $($ Cd recovery $)=0.0065+3.952$

Chromi um

$10.370 \sqrt{\mathrm{A}}-3.125$

Copper

$11.138 \sqrt{\mathrm{A}}-10.918$

Iron

$\mathrm{S}$

Lead

A

Magnest un

70.0

Manganese

S

Mercury

A

Nickel

$41.362 \operatorname{Ln}(A)-89.674$

Selenium

$9.738 \sqrt{\mathrm{A}}$

Silver

$9.602 \sqrt{\mathrm{s}}$

Tha111 um

Zinc

S

Urani um-238

21.03 Ln $(A+1)$

Thor 1 um-232

$21.03 \operatorname{Ln}(A+1)$

Radi un-226

A

Radi un-228

A

Lead -210

A

$A=$ Percentage recovery of ash.

$S$ = Percentage recovery of sulfur. 
Output Vector of Clean Coal Characteristics. The quantity of each element eppearing in the output clean coal vector is given by the following equation:

where

$$
\mathrm{QO}=0.66 \mathrm{QI}-\mathrm{QSW}+0.34 \mathrm{QI} \text { tons, }
$$

QO Is the quantity in clean coal,

QI Is the quantity in the input coal,

QSW is the quantity in the solld waste.

The total quantity of clean coal, calculated as the Input amount less the dry total solid waste, is also given as a separate output.

\section{Output Vector of Solid Waste}

The solid waste consists of a wet $>3 / 8-i n$. refuse and a $<28$-mesh slurry. The two waste streams may have different disposal requirements. The $>3 / 8-1 n$. refuse contains 6 to 12\% moisture and can be disposed of in a landfill, whereas the <28 mesh slurry contains 15 to $25 \%$ moisture and may require separate ponding. 2

The solid waste is therefore split into two output streams; $2.5 \%$ of which Is assumed to be $<28$ mesh (from Reference 2) and contains $20 \%$ mo1sture, and the remainder to have a molsture content of $9 \%$. All the elements are evenly divided between the two streams.

The total solid waste (element 25) is a wet weight and the total quantity of water (element 34) is also given. The other elements which compose the solid waste are given as dry quantities.

\subsubsection{Level 3 Cleaning}

The module assumes an overall Btu recovery of $85 \%$ (from Reference 2). In this case, all coal $>28$-mesh size is being cleaned and this constitutes $94 \%$ of 
the input coal (see Section 1.1.4). The Btu recovery for the coal subject to cleaning is $84 \%$.

The same equations are used as for Level 2 cleaning to determine the amounts of the major and minor components of the solid waste. However, theremoval rates 111 be greater because of the greater Btu removal. Also, the equations are applied to $94 \%$ of the incoming coal.

Again, the solid waste is split into two streams to reflect the different moisture content. In this case the $>3 / 8-1$. streams constitute $65 \%$ of the solfd waste and have a molsture content of $9 \%$; the remainder is assumed to have a moisture content of $20 \%$.

\subsection{Computer Code}

The computer code used is described in Appendix 1C. In Appendix 1D, there is a copy of the code along with a sample input and output. 
1. H. L. Lovel1, Sulfur Reduction Technologies in Coal by Mechanical Beneficiation, prepared for the Commerce Technical Advisory Board Panel on $\mathrm{SO}_{2}$ Control Technology, Pennsylvania State University, unpublished, 1975.

2. Gibbs and Hill Inc., Coal Preparation for Combustion and Conversion, prepared for Electric Power Research Institute, EPRI AF-791, 1978.

3. U.S. Bureau of Mines, Sulfur Reduction Potential of the Coals of the United States, RI $8118,1976$.

4. Hittman Associates, Inc., Environmental Impacts, Efficiency and Cost of Energy Supply and End Use, Volume 1, HIT-593, 1974.

5. J. W. Leonard (ed.), Coal Preparation, The American Institute of Mining, Metallurgical and Petroleum Engineers, Inc., New York, 1968.

6. Memorandum from Teknekron Research, Inc., 1980.

7. H. J. Gluskoter, R. R. Ruch, W. G. Miller, R. A. Cahill, G. B. Dreher, and J. K. Kuhn, Trace Elements in Coal: Occurrence and Distribution, Illinois State Geological Survey, EPA-600/7-77-064, 1977.

8. C. T. Ford, Coal Cleaning to Remove Trace Elements Prior to Utilization, . Proceedings of the Fourth Symposium on Coal Utilization, National Coal Association, p. 146, CONF-7710110, 1977.

9. J. A. Cavallaro, A. W. Deurbrouck, H. Schultz, G. A. Gibbon, and E. A. Hattman, A Washability and Analytical Evaluation of Potentlal Pollution from Trace Elements in Coal, Pittsburgh Energy Research Center, EPA-600/7-78-038, Mar. 1978.

10. S.P. Babu (e...), Trace Elements in Fuel, Advances in Chemistry Series, 141, American Chemical Society, 1975.

11. N. H. Nie, C. H. Hull, J. G. Jenkins, K. Steinbrenner, and D. H. Bent, Statistical Package for the Social Sclences, Second Edition, McGraw Hill, 1975. 
EQUATIONS FOR REMOVAL RATES OF MAJOR COAL COMPONENTS (CARBON, ASH, SULFUR) IN COAL CLEANING, LEVELS 2 AND 3

In determining equations for use in estimating the removal rates of varlous components of coal, certain assumptions had to be made in regard to which variables were directly related, and in what form. These assumptions were restricted by ilmited avallable data and the desire to keep the model as simple as possible. The following assumptions were made in constructing the coal cleaning module:

1. For each level (2 and 3 ) of coal cleaning, the Btu removal rate (BTUREM) is fixed.

2. PCWASTE $=f(B T U R E M, P C A S H)$, where

PCWASTE $=\%$ total coal removal,

PCASH $=\%$ ash content of the raw coal.

3. \% removal of carbon $=$ BTUREM.

4. Other elements in the raw coal not accounted for (mainly oxygen and nitrogen $)=($ total coa 1$)-($ carbon content $)-($ ash content $)-$ (sulfur content).

5. \% removal rate of other elements = BTUREM.

6. Amount of ash removed $=$ (total coal removed) - (carbon removed) (other removed).

7. \% organic sulfur removal (ORGSREM) = BTUREM.

8. \% pyritic sulfur removal (PCPSREM) = f(PCASHR, PCPYRS, PCWASTE, BTUREM), 
where

PCPYRS $\approx \%$ pyritic sulfur content of the raw coal.

9. \% removal of trace metals $=\mathrm{f}$ (PCASHR or PCPSREM) (see Appendix $1 \mathrm{~B}$ ).

After the above assumptions were made, data were obtained from Reference 3 for 455 coal samples which were subjected to float-sink washability studies. The clean coal used was the Float-1.6 fraction. This is the approximate specific gravity used in coal cleaning plants, as it gives the best tradeoff between the amount of coal recovered and the sulfur and ash removal.

The following variables were obtained or calculated from Reference 3:

1. \% total coal removal (PCWASTE).

2. \% total Btu removal (BTUREM).

3. \% total ash content (PCASH).

4. \% total pyritic sulfur content (PCPYRS).

5. \% total ash removal (PCASHR).

6. \% total pyritic sulfur removal (PCPSREM).

Because of analytical error, typographical error, or a coal sample which seemed extremely uncharacteristic in terms of one or more of its components, certain of the coal samples were eliminated before deriving the removal rate equations. After elimination, there were 441 coal samples avallable for use in the estimation of the equations.

Using the SPSS ${ }^{11}$ regression program and the above assumptions, the following equations were obtained:

1. PCWASTE $=.719($ PCASH $)+.890($ BTUREM $)-3.698 \quad\left(R^{2}=.92\right)$

2. PCPSREM $=.686($ PCASHR $)+2.499($ BTUREM $)+127.286(\operatorname{Ln}(100-$ PCWASTE $))$

$+3.578(\operatorname{Ln}($ PCPYRS $))-584.565$

$\left(R^{2}=.47\right)$ 


\section{B.1 Calculation of Fractionation Factors for Trace Elements}

Using the results from the reports detalled in section 1.2.3, the fraction of each trace element which appeared in the clean coal was calculated on a whole coal basis.

An example of how the data were converted to fractionation factors is given in Table 1B.l.

Table 1B.1

Example of Calculation of Fractionation Factor Using Results for Nickel

\begin{tabular}{|c|c|c|c|c|}
\hline & $\begin{array}{c}\text { Concentration } \\
\text { ppm }\end{array}$ & $\begin{array}{l}\text { Weight } \\
\text { Fraction }\end{array}$ & $\begin{array}{l}\text { Weighted } \\
\text { Concen- } \\
\text { tration }\end{array}$ & $\begin{array}{l}\text { Weighted } \\
\begin{array}{l}\text { Concen- } \\
\text { tration }\end{array} \times \frac{11.0}{10.275}\end{array}$ \\
\hline $\begin{array}{l}\text { Float } 1.29 \\
\text { Float } 1.33 \\
\text { Float } 1.40 \\
\text { Float } 1.60 \\
\text { Sink } 1.60 \\
\text { Composite } \\
\text { Feed coal }\end{array}$ & $\begin{array}{c}8.0 \\
8.0 \\
10.0 \\
10.0 \\
27.0 \\
11.0\end{array}$ & $\begin{array}{l}0.343 \\
0.259 \\
0.186 \\
0.125 \\
0.087 \\
1.00\end{array}$ & $\begin{array}{r}2.744 \\
2.072 \\
1.860 \\
1.250 \\
2.349 \\
10.275 \\
11.00\end{array}$ & $\begin{array}{r}2.938 \\
.2 .218 \\
1.991 \\
1.338 \\
8.485\end{array}$ \\
\hline
\end{tabular}

Corrected concentration $=8.485 \times \frac{100}{91.3}=9.29$.

Fractionation factor to clean $\operatorname{coa} 1=\frac{9.29}{11.00}=0.8449$.

The determined concentrations were multiplied by the weight fraction of the total coal found in each specific gravity zone to obtain the weighted concentration values. These values were "normalized" so that their summation totals the determined concentration of the feed $(11.0 \mathrm{ppm}$ in the example given). This was done by multiplying each of the weighted concentration 
values by the feed value (11.00), and dividing by 10.275 , the summation of the weighted concentration values. The summation of these then equalled the feed value.

The total of these values for the "float" zones represents the weighted total concentration values in the four zones which are to represent the final cleaned coal. In this case these zones represented $91.3 \%$ of the total feed coal. To obtain the final concentration value for the cleaned coal, the value for $91.3 \%$ again had to be normalized to reflect $100 \%$. This was done by multiplying the 8.485 by 100 and dividing by 91.3 to obtain 9.29 as concentration in the clean coal.

The fractionation factor is then determined by dividing 9.29 by the original concentration in the coal (11.0) to give a factor of 0.8449 , which In this case represents the fraction of nickel remaining in the coal after washing.

Table 1B.2 gives the results and Table $1 \mathrm{~B} .3$ gives the key to the figures as to where the coal samples come from and which reference was used.

\section{B.2 Estimation of Trace Element Removal Rates}

While it is acknowledged that removal of trace elements is not a simple function and is subject to large variation, an effort was made to make the estimation of removal rates as simple as possible. This was accomplished by assuming that the removal rate of each trace element is a function of the removal rate of efther ash or pyritic sulfur.

The data for trace elements as described above were plotted vs the ash and pyritic sulfur data. (Note: the data above are expressed in terms of fraction recovery rate, 1.e., the proportion of the component which ends up in 
Table 1B. 2

Trace Hetal Coal Cleaning Data

Fraction to clean Coal

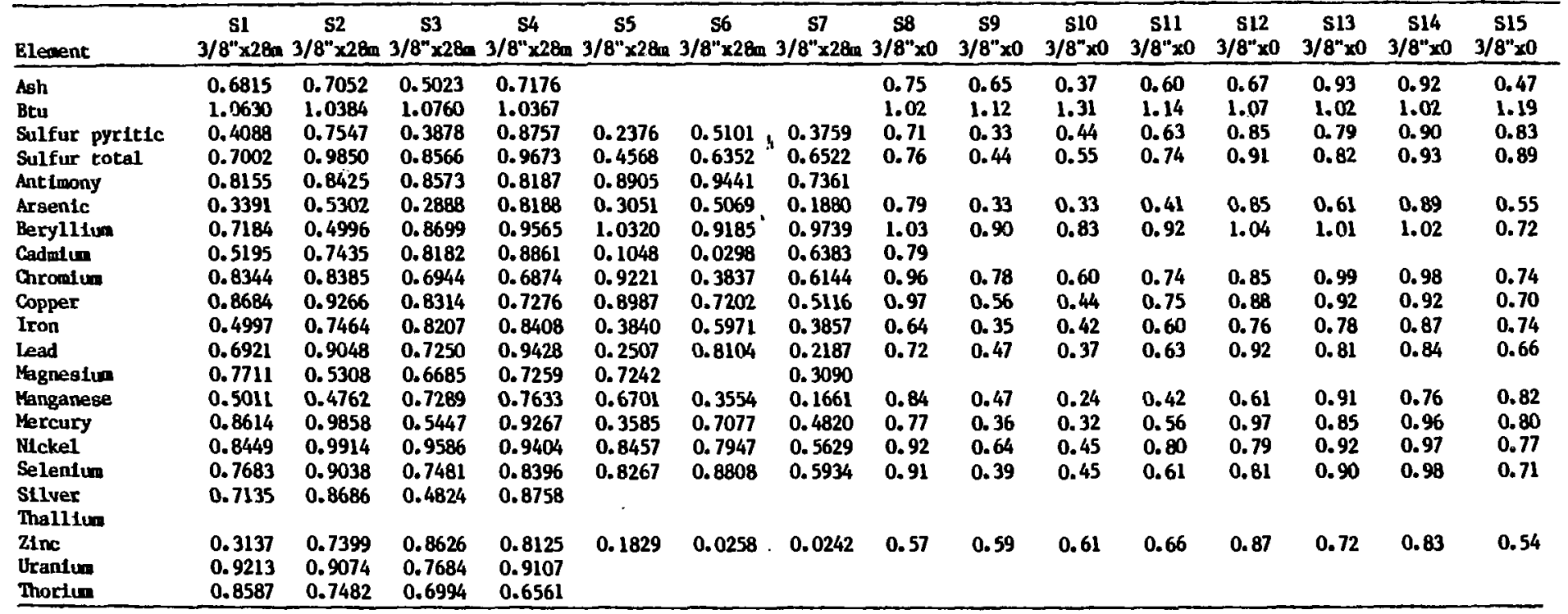




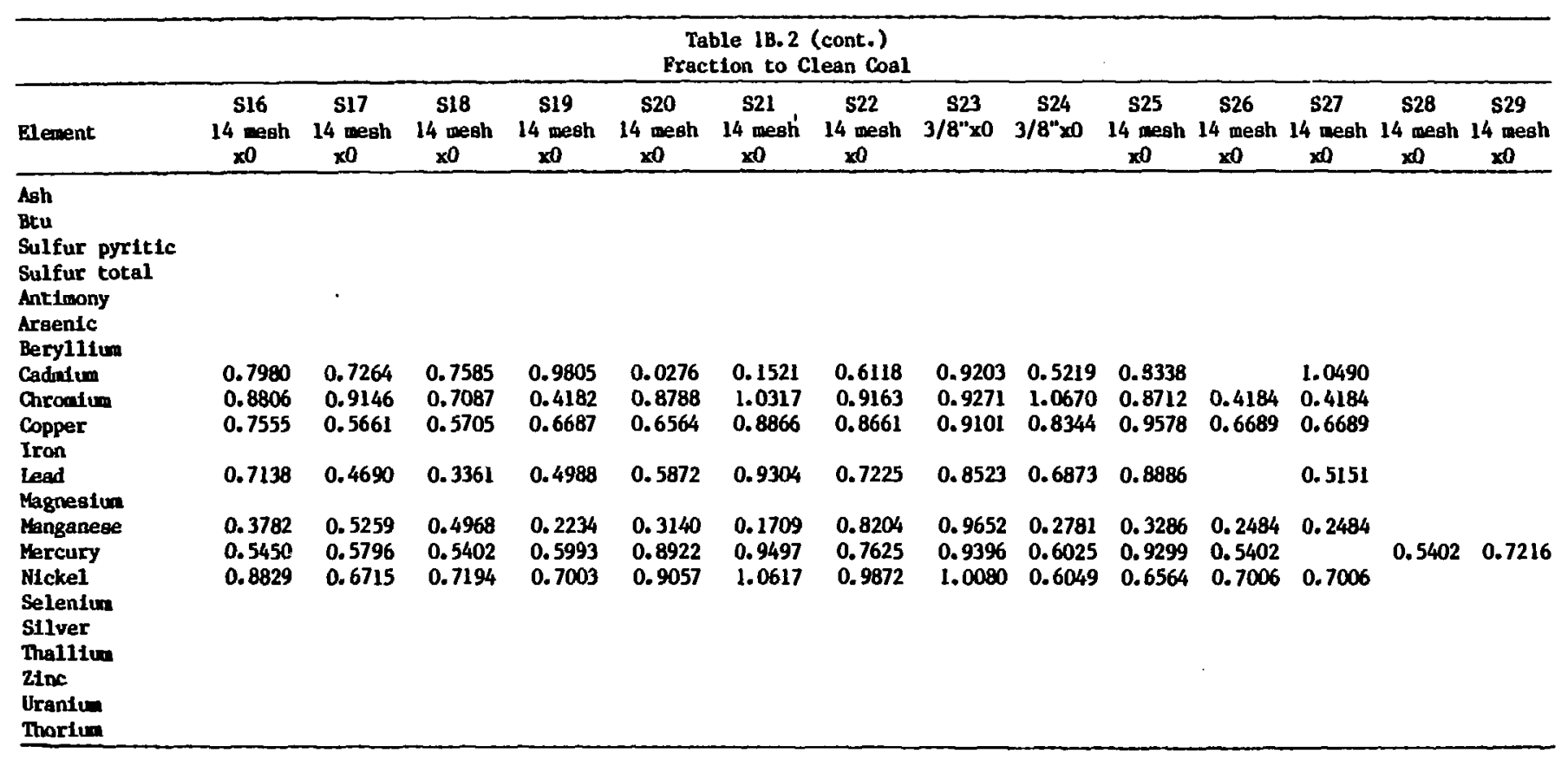


Table 1b,3

Key to Trace Metal Factors

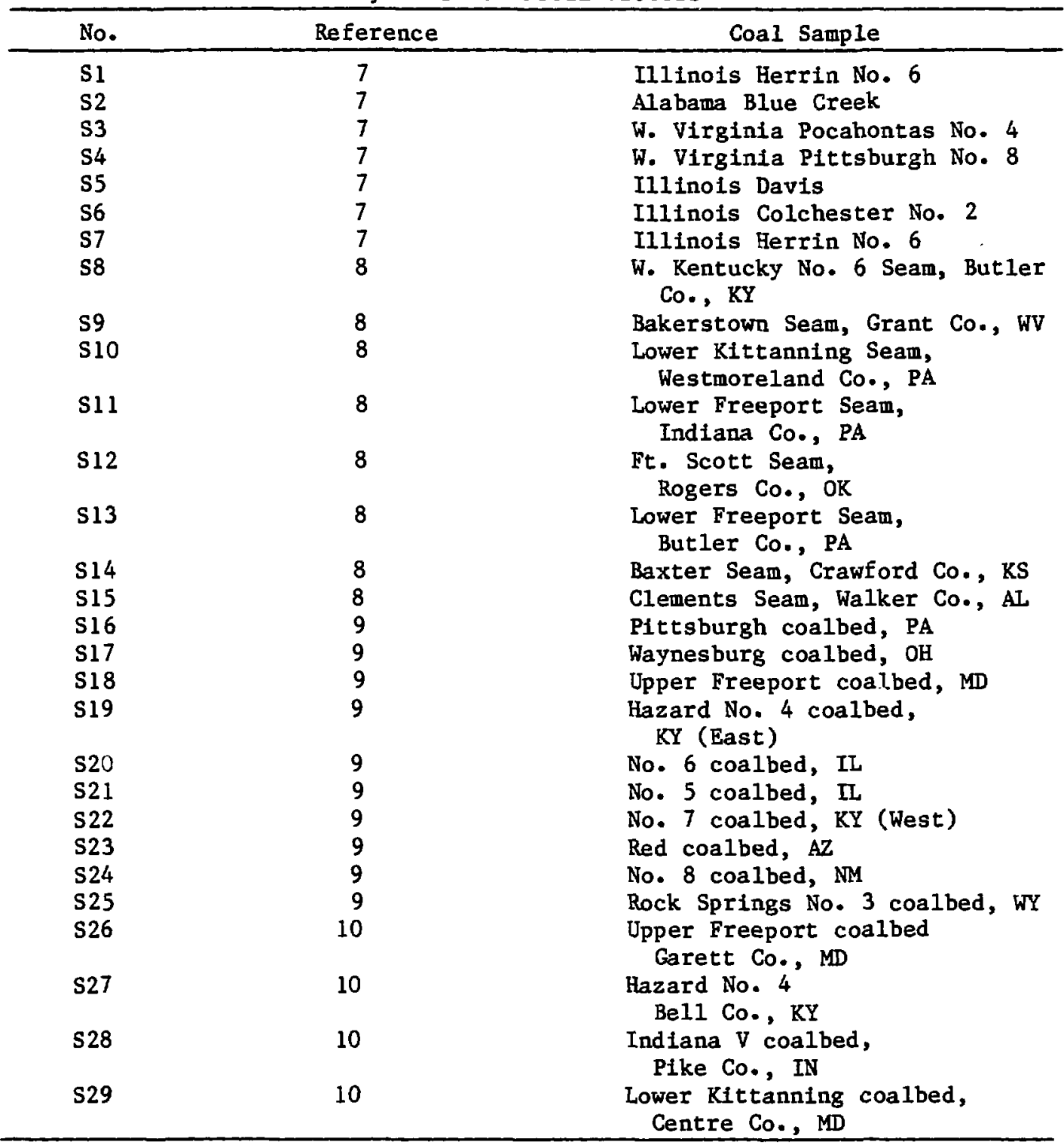


the clean coal. The functions derived below are given in terms of percentage recovery rate, $100 \times$ (proportion recovered). The fraction removal rate as calculated in the computer module is determined by

$$
F(E)=(100-R(E)) / 100 \text {, }
$$

where

$$
\begin{aligned}
& F(E)=\text { fraction removal of trace elrment } E, \\
& R(E)=\text { percent recovery rate of trace element } E,
\end{aligned}
$$

and $R(E)$ for all. trace elements are described below. The data supplied between four and twelve points per graph.

The graphs were then compared to sample graphs which showed the form for the linear, log, and square root functions. The best form for each element was chosen, and a line was fitted for each element according to Table 1.B4, using least squares regression. In some cases, data points which seemed to be outliers were eliminated before fitting a line (See comments, Table 1B.4). Some of the trace elements showed no pattern, but were grouped around a certain recovery rate, and were therefore assigned a constant (average) recovery rate. 
Table 1B. 4

Trace Element Recovery as a Function of Ash or Pyritic Sulfur Recovery

\begin{tabular}{|c|c|c|c|}
\hline $\begin{array}{c}\text { Trace } \\
\text { Element }\end{array}$ & $\begin{array}{c}\text { Functional } \\
\text { Form* }\end{array}$ & Equation** & Comments \\
\hline Antimony & Average & $R=85.0$ & $\begin{array}{l}\text { Deleted } s_{6}, s_{7}(\max \text { and } \\
\text { min values) }\end{array}$ \\
\hline Arsenic & Linear (A) & $R=A$ & - \\
\hline Beryllium & $\mathrm{Sq} \cdot \operatorname{root}(\mathrm{A})$ & $R=4.641 \sqrt{A}+49.713$ & \\
\hline Cadmium & Exponential(s) & $\operatorname{Ln}(R)=.006 \mathrm{~S}+3.952$ & Deleted $s_{5}, s_{6}$ \\
\hline Chromium & $S q \cdot \operatorname{root}(A)$ & $R=10.370 \sqrt{A}-3.125$ & - \\
\hline Copper & " " & $R=11.138 \sqrt{A}-10.918$ & $8-$ \\
\hline Iron & Linear (S) & $R=S$ & - \\
\hline Lead & Linear (A) & $R=A$ & $\begin{array}{l}\text { Assumed } \mathrm{Pb} 210 \text { rate is } \\
\text { same as lead }\end{array}$ \\
\hline Magnesium & Average & $R=70.0$ & Used approximate mode \\
\hline Manganese & Linear (S) & $\mathbf{R}=\mathbf{S}$ & - \\
\hline Mercury & Linear (A) & $R=A$ & $\begin{array}{l}\text { Regression line, when } \\
\text { forced through origin, } \\
\text { is } R=1.106 \mathrm{~A}\end{array}$ \\
\hline Nickel & $\log (A)$ & $\begin{aligned} R= & 41.362 \operatorname{Ln}(A) \\
& -89.674\end{aligned}$ & - \\
\hline Selenium & Sq. $\operatorname{root}(A)$ & $R=9.738 \sqrt{A}$ & $\begin{array}{l}\text { Deleted } \mathrm{S}_{9} \text {, forced line } \\
\text { through origin }\end{array}$ \\
\hline Silver & $S q \cdot \operatorname{root}(s)$ & $R=9.602 \sqrt{\mathrm{S}}$ & Forced line through origin \\
\hline Thallium & - & - & No data available, set $=0$ \\
\hline Zinc & Linear (S) & $\mathbf{R}=\mathbf{S}$ & - \\
\hline $\begin{array}{l}\text { Uranium and } \\
\text { Thorium }\end{array}$ & $\log (A)$ & $R=21.03 \operatorname{Ln}(A+1)$ & $\begin{array}{l}\text { Line estimated using } \\
\text { uranium data and forced } \\
\text { through origin }\end{array}$ \\
\hline $\begin{array}{l}\text { Radium-226 anc } \\
\text { Radium-228 }\end{array}$ & d Linear (A) & $\mathbf{R}=\mathbf{A}$ & - \\
\hline Lead-210 & Linear (A) & $R=A$ & Assumed same rates as lead \\
\hline $\begin{aligned} & * \quad \text { Functional } \\
& X=\quad S \\
& * * \quad=\text { trace } \\
& A=\text { ash rec } \\
& S=\text { pyritic }\end{aligned}$ & $\begin{array}{l}\text { form given as } F \\
\text { (ash recovery ra } \\
\text { (pyritic sulfur } \\
\text { element recovery } \\
\text { covery rate, } \\
\text { c sulfur recover }\end{array}$ & $\begin{array}{l}F(X) \text { where } F \text { is the } f \\
\text { ate or, } \\
\text { recovery rate). } \\
\text { rate, } \\
\text { ry rate. }\end{array}$ & Eunction and \\
\hline
\end{tabular}




\section{APPENDIX IC}

DESCRIPTION OF COMPUTER MODULE

The computer module for the coal cleaning process consists of four subroutines (CLEAN, TRACE, STRSPL, CPRINT). The module is operated by making a call to CLEAN,

Ca11 CLEAN (Q, LEVEL, COAL), where

Q $\quad=$ total amount of coal.

LEVEL = integer value, Indicates the level of coal cleaning desired. Acceptable values of LEVEL are 1, 2, or 3. Any other value will immediately return control to the calling program.

COAL = input vector of coal characteristics, dimension 50. On output it will contain the characteristics of the cleaned coal.

For LEVEL 1 cleaning (sizing), CLEAN will calculate all output characteristics directly. For other levels, it will set the Btu removal rate, the coal split for the cleaned and passed-through coal, and the split for the two solid waste output streams and calculate the percentage of ash and pyritic sulfur in the coal. It will then call subroutines TRACE and STRSPL to calculate the major component and trace metal removal rates and the solid waste split, respectively.

After the characteristics of the solid waste are determined, subroutine CPRINT is called to print out all inpu: and output vectors.

Subroutine TRACE

Using the Btu removal rate and the ash and pyritic sulfur content from subroutine CLEAN, the solid waste characteristics are calculated in TRACE as 
slown in Appendix 1A (ash, carbon, sulfur) and Appendix 1B (trace metals). The solid waste characteristics are placed in vector STREAMl.

The removal rates of all components, which were in percentages, are converted to proportions. Control is returned to subroutine CLEAN.

Subroutine STRSPL

After cleaning at level 2 or 3 , the solid waste is split into two streams for different levels of disposal. STRSPL converts the output solid waste calculated in TRACE to two output waste streams (which will contain water).

\section{Subroutine CPRINT}

Subroutine CPRINT prints out the input and output vectors used in the module. For each element, output consists of:

1. Fraction removed - this fraction is the fraction removed of only the coal which is cleaned (all for Level 1, appropriate amounts for 2 and 3).

2. Input coal components.

3. Clean coal components.

4. STREAM1 and STREAM2 - solid waste streams as determined for levels 2 and 3. For Level 1, STREAM1 will contain all of the solld waste, STREAM2 will be a zero vector.

\section{Special notes:}

1. If the $\mathrm{Ra}^{226}, \mathrm{Ra}^{228}$ and $\mathrm{Pb}^{210}$ elements of the input coal are zero, they w1ll be calculated from uranium and thorium (see Section 7) upon calling CLEAN even if LEVEL is a value other than 1,2 , or 3.

2. The input coal vector is saved in vector OCOAl within the subroutine CPRINT. 
3. For Levels 2 and 3 , a certain proportion of the coal is cleaned and a certain proportion is passed through to the output coal. After part is cleaned (by calls to subroutines TRACE and STRSPL), the cleaned and passed-through coal vectors are added together to give the characteristics of the total cleaned coal.

4. Common block REM (dimension 24) is used in storing removal rates which are printed in CPRINT.

5. Fraction of total sulfur removed on output is the fraction of organic sulfur removed, while all other values of total sulfur are of total sulfur (organic and pyritic). Total sulfur removed is calculated by Organic sulfur content $=$ Total sulfur content - pyritic sulfur content.

Total sulfur removed $=$ (fraction organic sulfur removed)

$$
\begin{aligned}
& \text { x (organic sulfur content) } \\
& + \text { (fraction pyritic sulfur removed) } \\
& \text { x (pyritic sulfur content) }
\end{aligned}
$$

6. Empty vector elements which are not used or are not applicable to the coal cleaning process are set to zero but are not printed.

7. No data were available for calculating fraction removed of thallium in Levels 2 and 3, and are set at zero.

8. Fraction removed of total solid waste is the fraction of the total coal removed by weight. 


\section{APPENDIX 1D}

COMPUTER CODE AND SAMPLE OUTPUT

This appendix sets out the computer code used for the coal-cleaning module with a sample input and tire resulting output. Table $1 D .1$ gives the coal characteristics used as input. The other input variables used were as follows:

Quantity of $\operatorname{coal}(Q)=100,000.0$ tons,

Level of cleaning $($ LEVEL $)=2$.

For total sulfur (element 2) the fraction removed in fact applies to. organic sulfur only, although the rest of the vectors give the data for total sulfur (pyritic and organic).

Table 1D. 1

Input Characteristics of Coal

\begin{tabular}{lc}
\hline \multicolumn{1}{c}{ Element } & Input Quantity (tons) \\
\hline Ash & 18700.00 \\
Sulfur & 3000.00 \\
Antimony & 0.07 \\
Arsenic & 2.70 \\
Berylitum & 0.50 \\
Cadmium & 0.125 \\
Chromium & 3.00 \\
Copper & 1.18 \\
Iron & 2700.00 \\
Lead & 1.14 \\
Magnesium & 118.00 \\
Manganese & 7.40 \\
Mercury & 0.017 \\
Nickel & 2.00 \\
Selenium & 0.02 \\
Silver & 0.01 \\
Zinc & 1.69 \\
Uranium & 0.07 \\
Thorium & 0.66 \\
Pyritic sulfur & 1870.00 \\
Carbon & 64100.00 \\
Btu & $2.3 \mathrm{E} 12$ \\
\hline
\end{tabular}


PROGRAM CLL (OUTPUT, TAPEZ=OUTPUT )

DIMENSION COAL (5D)

$\mathrm{Q}=100000$

$\operatorname{COAL}(1)=18700$.

$\operatorname{COAL}(2)=3000$

$\operatorname{COAL}(3)=.07$

$\operatorname{COAL}(4)=2.7$

$\operatorname{COAL}(5)=.5$

$\operatorname{COAL}(6)=.125$

$\operatorname{COAL}(7)=3$.

$\operatorname{COAL}(8)=1.18$

COAL $(9)=2700$

$\operatorname{COAL}(10)=1.14$

$\operatorname{COAL}(1 !)=118$.

$\operatorname{COAL}(12)=7,4$

$\operatorname{COAL}(13)=.017$

$\operatorname{COAL}(14)=2$.

$\operatorname{COAL}(15)=.02$

$\operatorname{COAL}(I 6)=.01$

$\operatorname{COAL}(17)=0$

$\operatorname{COAL}(18)=1.69$

$\operatorname{COAL}(19)=.07$

$\operatorname{COAL}(20)=.66$

DO $10 \quad I=21,38$

COAL (I) $=0$.

10 CONT INUE

$\operatorname{COAL}(39)=1870$.

$\operatorname{COAL}(40)=64100$

COAL $(41)=2.3 E 12$

DO $20[=42,50$

$\operatorname{COAL}($ I $)=0$.

20 CONTINUE

$\operatorname{COAL}(17)=1$

LEVEL $=2$

CALL CLEAN (Q,LEVEL, COAL)

STOP

END 
SUBROUT INE CLEAN(Q, LEVEL, COAL)

DIMENSION COAL (50), SCOAL (50), STREAM! (50), STREAM2 (50), OCOAL (50)

COMMON/REM/REMOV (24)

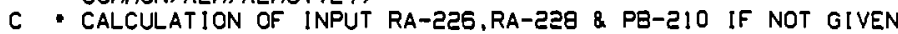

If (COAL (21) .EO. 0.) COAL $(21)=3.38 E-7 \cdot \operatorname{COAL}(19)$

IF (COAL (22) .EQ. O.) COAL $(22)=4,01 E-10 \cdot \operatorname{COAL}(20)$

IF $(\operatorname{COAL}(23)$.EQ. 0,$) \operatorname{COAL}(23)=4,37 E-9 * \operatorname{COAL}(19)$

DO $\quad I=1,50$

C * OCOAL USED TO STORE INPUT CHARACTERISTICS FOR PRINT OUT OCOAL ( I) = COAL (U)

1 CONT INUE

IF ILEVEL .EQ. 3)GO TO 100

IF ILEVEL .EO. ZIGO TO 100

C * LEVEL MUST BE AN INTEgER BeTWEeN 1 AND 3

1F (LEVEL . NE. 1)GO TO 5000

C * calculation of waste from level I Cleaning

C CALCULATION OF FRACTION OF INCOMING ASH REMOVED POTHER $=(.02 * 0-.005 *$ COAL (40))/(0-COAL (40))

C - CALCULATION OF INPUT AMOUNT OF ORGANIC SULFUR ORGS =COAL (2)-COAL (39)

C CALCULATION OF aMOUNT OF ORgANIC SULFUR REMOVEO ORGSREM=.005*ORGS

C calculation of aSH in waste and clean coal STREAM I ( ) =POTHER *COAL ( 1$)$ COAL ( 1$)=$ COAL (1)-STREAMI (1)

C * CalCulation of trace element sPlit betweEn waste and Clean coal DO 10 [ $=3,24$ STREAMI $(1)=$ POTHER *COAL ( I) COAL $(I)=\operatorname{COAL}([)-$ STREAMI (I)

10 CONTINUE

C calculation of water content of SOl ID waste STREAMI (25) $\times$. D2*0

C NON-APPL ICABLE ELEMENTS SET TO ZERO DO $20 \quad 1=26,38$ STREAMI $(l)=0$.

20 CONTINUE

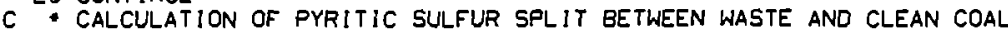
STREAM! (39) =POTHER • COAL ( 39 ) COAL (39) = COAL (39) -STREAMI (39)

C * calculation of total Sulfur split between waste and Clean coal STREAM! $(2)=$ STREAM! ( 39$)+$ ORGSREM $\operatorname{COAL}(2)=\operatorname{COAL}(2)-S T R E A M)(2)$

C SPL IT OF CARBon and bTUs between waste and Clean coal STREAMI $(40)=.005 \cdot \operatorname{COAL}(40)$ STREAMI $(41)=.005 *$ COAL $(4$ I) COAL $(40)=$ COAL $(40)-$ STREAMI $(40)$ $\operatorname{COAL}(41)=\operatorname{COAL}(41)-$ STREAM $1(41)$ DO $30 \quad[=42,50$

C NON-APPLICABLE ElEMENTS SET to ZERO STREAM $(1)=0$.

30 CONTINUE

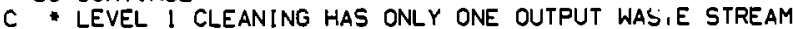
DO $40 \quad I=1,50$ STREAM2 $(1)=0$.

40 CONT INUE

C ouantity of Clean coal calculated OCLEAN=0-STREAMI (25)

c. FRaction of each Element Removed calculated for pRintout REMOV $(1)=.02$ REMOV $(2)=$ POTHER

REMOV $(3)=.005$

DO 50 I $\times 4,24$

REMOV (1)=POTHER 
50 CONT INUE BTUREM $=.005$ GO TO 500

C - Calculation of haste from level 2 and 3 cleaning

C - bTu Removal percentage set for levels 2 and 3

100 [F (LEVEL .EQ. Z) BTUREM $=10.6$ IF (LEVEL .EO. 3)BTUREM $=16.0$

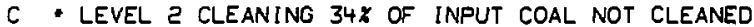

C * LEVEL 3 Cleaning $6 x$ OF INPUT COAL NOT CLEANED IF (LEVEL .EO. 2]SPL IT $=.34$ IF (LEVEL .EO. 3] SPLIT $=.06$

C LEVEL 2 WASTE STREAMS SPLIT $97.5 \%$ AND $2.5 \%$

C - LEVEL 3 haSTE STREAMS SPLIT 65X AND 35\% IF ILEVEL .EO. 2) S2SPL I T = .025 IF ILEVEL .EQ. 3) SZSPL I T $=.350$

C - CalCULATION OF PERCENTAGe of ash AND pyritic sulfur IN INPUT COAL PCASH $=100$. COAL 11$) / 0$ PCPYRS $=100 \cdot$ COAL (39)/0

C - INPUT ELEMENTS SPLIT BETWEEN COAL NOT SUBJECT to CLEANING AND

C - coal subject to cleaning DO $110 \quad I=1,24$

$\operatorname{SCOAL}(1)=S P L I T * \operatorname{COAL}(1)$

$\operatorname{COAL}([)=\operatorname{COAL}(1)-S \operatorname{COAL}([)$

110 CONT INUE

DO $120 \quad i=39,41$

SCOAL ( I) $=$ SPL I T $*$ COAL ( 1)

COAL $(1)=\operatorname{COAL}(1)-S C O A L($ I)

120 CONT INUE

c * calculation of ouantity of coal subject to cleaning OSPL I T $=0-S P L I T \cdot 0$

CALL TRACE (OSPLIT GTUREM,PCASH, PCPYRS, COAL , STREAMI)

CALL STRSPL (SESPL I T, STREAMI, STREAMZ)

C - CALCULATION OF TOTAL OUANTITY OF EACH ELEMENT IN OUTPUT COAL

C - Element in Clean coal + Element IN COAL not subject to cleaning DO $130 \quad I=1,24$

$\operatorname{COAL}(1)=\operatorname{COAL}(1)+S \operatorname{COAL}(1)$

130 CONT INUE

DO $140 \quad \mathrm{I}=39,41$

$\operatorname{COAL}(1)=\operatorname{COAL}(I)+5 \operatorname{COAL}(I)$

140 CONT INUE

C - calculation of total output quantity of coal

QCLEAN=OSPL IT+SPLIT*Q

500 CALL CPRINT (, , OCLEAN, BTUREM, COAL, STREAMI, STREAMZ, OCOAL)

5000 RETURN

END 
SUBROUT INE TRACE (O, BTUREM, PCASH, PCPYRS, COAL, STREAMI)

C - used to calculate tHe SPL IT beTWeEn haste and Clean coal

- FOR EACH ELEMENT

DIMENSI ON COAL (50), STREAMI (50)

REAL SBREC, SBREM, ASREC ASREM, BEREC , BEREM, CDREC, CDREM,

-CRREC, CRREM , CUREC, CUREM , FEREM, PBREM, MGREC, MGREM, MNREM,

- NIREC, NIREM, HGREM, SEREC, SEREM, AGREC, AGREM, ZNREM, UREC, UREM,

-THREM,PBZIOR

COMMON/REM/PCWASTE, PCASHR, PCOSREM, SBREM, ASREM, BEREM, CDREM, CRREM,

-CUREM, FEREM, PEREM, MGREM, MNREM, HGREM, NIREM, SEREM, AGREM,

-ZNREM, UREM, THREM, RAREM, PBZI OR, PCPSREM, TLREM

C - CALCULATION OF PERCENTAGE OF INPUT COAL REMOVED AS WASTE

PCWASTE $=.719 *$ PCASH+.890 -BTUREM-3.698

C - CALCULATION OF TOTAL DRY WASTE

WASTE $=$ PCWASTE $* 0 / 100$

C calculation of amount of carbon removeo CREM $=B$ TUREM $*$ COAL $(40) / 100$.

C calculation of O,N AND H in COAL OXNI T =O-COAL (1) -COAL (2) -COAL (4O)

C - CALCULATION OF ASH CONTENT OF WASTE ASHREM=WASTE-CREM-ETUREM"OXNI T/ 100.

C CALCULATION OF INPUT ORGANIC SULFUR ORGS=COAL (2) -COAL (39)

C * CalCulation of percentage of ash REMOVED PCASHRx 100. ASHREM/COAL (1)

C - CALCULATION OF PERCENTAGE OF PYRITIC SULFUR REMOVED PCPSREM $=.686$ *PCASHR+2. 499*BTUREM+127. 286*ALOG $(100 .-P C W A S T E)$

$-+3.579 \cdot A L O G$ (PCPYRS) -584.565

C CALCULATION OF OUANTITY OF EACH ELEMENT IN WASTE AND CLEAN COAL

C VARIABLE NAMES ENDING IN 'RC REFER TO $*$ RECOVERED IN CLEAN

C - COAL AND 'REM' REFERS TO $*$ REMOVED

ASH

PCASHRC $=100,-$ PCASHR

STREAMI $(1)=$ PCASHR*COAL $(1) / 100$.

COAL $(1)=\operatorname{COAL}(1)-$ STREAM $1(1)$

$\mathrm{C}$
$\mathrm{C}$

INORGANIC (PYRITIC) SULFUR

PCPSRC $=100 .-P C P S R E M$

STREAMI $(39)=$ PCPSREM+COAL $(39) / 100$

$c$
$C$

$\operatorname{COAL}(39)=\operatorname{COAL}(39)-$ STREAMI $(39)$

TOTAL SULFUR

ORGSREM $=9$ TUREM $M$ ORGS $/ 100$.

PCOSREM=ORGSREM $/$ ORGS

STREAMI ( 2 ) =STREAM] (39)+ORGSREM

$\operatorname{COAL}(2)=\operatorname{COAL}(2)-S T R E A M I(2)$

$\mathrm{C}$
$\mathrm{C}$

CARBON AND BTU

STREAMI $(40)=\theta$ TUREM $*$ COAL $(40) / 100$.

COAL $(40)=$ COAL $(40)-S T R E A M I(40)$

$\operatorname{COAL}(41)=\operatorname{COAL}(41)-\mathrm{BTUREM}+\operatorname{COAL}(4) 1) 100$

$\stackrel{c}{c}$

STREAMI $(41)=0$.

ANT IMONY

SBREC $=85,0$

SBREM $=(100 .-$ SEREC $) / 100$.

STREAMI ( 3$]=$ SBREM* COAL $(3)$ 


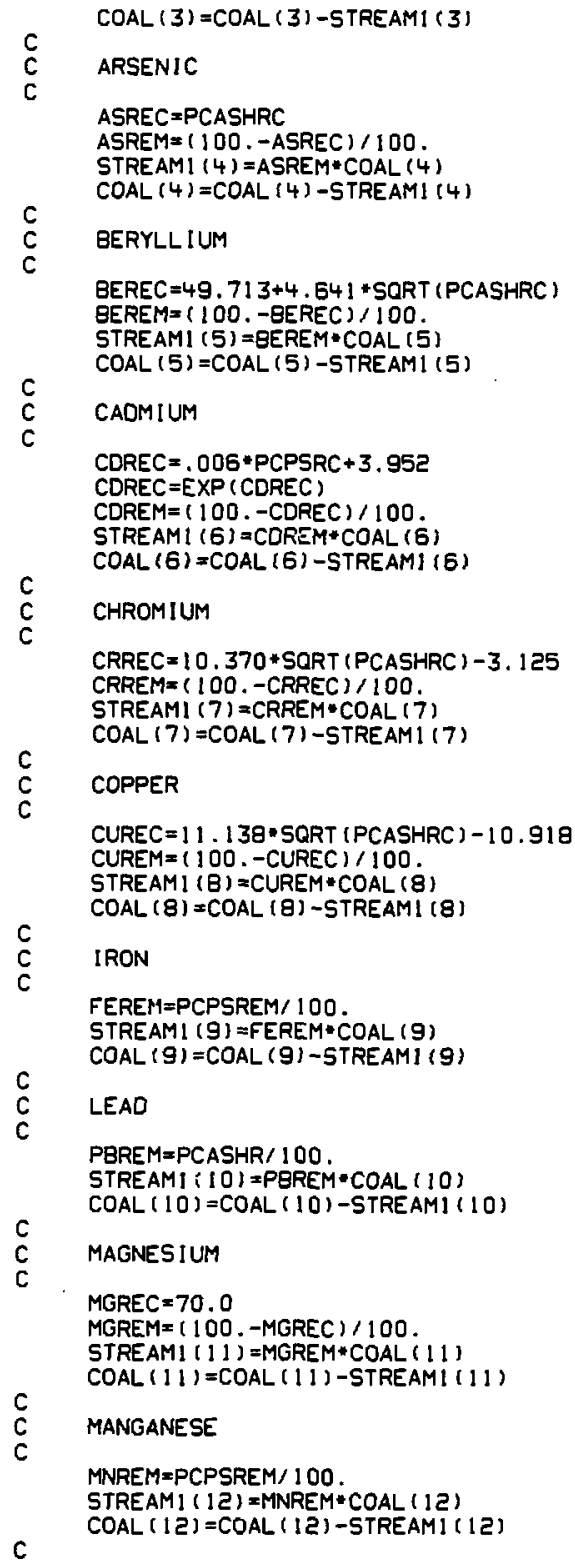




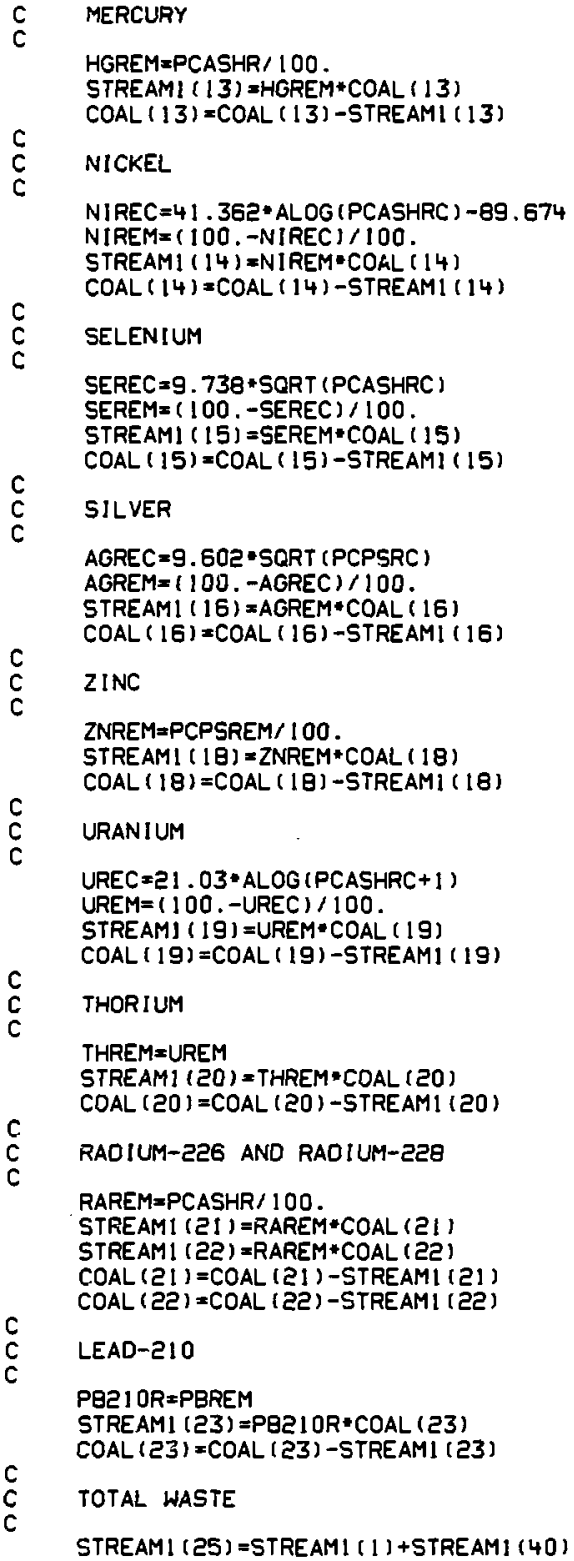


TLREM $=0$.

STREAM $1(17)=0$.

STREAM! $(24)=0$.

DO $10 \quad[=26,38$

STREAMI $(i)=0$.

10 CONT INUE

DO $20 \quad\{=42,50$

STREAMI $(I)=0$.

20 CONT INUE

C PERCENTAGe REMOVALS CONVERTED to FRACTIONS FOR PRINT OUT

PCASHR=PCASHR/100.

GTUREM=GTUREM/ 100 .

PCPSREM XPCPSREM/100.

PCWASTE =PCWASTE $/ 100$.

c calculation of QUANTity of clean coal

$Q=Q-P C W A S T E * Q$

RETURNGEND

SUBROUT INE STRSPL (SESPL I T , STREAMI , STREAME)

C - SPLITS WASTE INTO TWO STREAMS TO REFLECT OIFFERENT DISPOSAL PRACTISES DIMENSION STREAMI (50), STREAM2(50) DO $10 \quad[=1,50$

c aLL ELEMENTS SPLIT INTO 2 WASTE STREAMS, FRACTIONAL SPLIT

C * (SZSPL IT) DEF INED IN SUBROUT INE CLEAN STREAMZ (I) =SZSPL I T * STREAMI ( I) STREAM ( [ ] $=$ STREAMI ( I) -STREAM ( I)

10 CONTINUE

C - CAlCUlation of water content of tHe 2 waste streams STREAM! $(34)=.09 *$ STREAMI $(25)$ STREAME $(34)=.20$ - STREAM2 (25)

C - CalCULATION OF THE tOTAL hET WEIGHT OF THE 2 waste streams STREAMI (25) =STREAMI (25) +STREAM) (34) STREAM2 (25) =STREAM2 (25) +STREAM2 (34) RETURNSEND

SUBROUT INE CPRINT (Q, QCLEAN, BTUREM, COAL, STREAMI , STREAM2, OCOAL) DIMENSION COAL (50), STREAMI (50), STREAM2 (50), OCOAL (50) COMMON/REM/PCWASTE, PCASHR, ORGSREM, SBREM, ASREM, BEREM, CDREM, CRREM, - CUREM, FEREM, PBREM, MGREM, MNREM, HGREM, NI REM, SEREM, AGREM, -ZNREM, UREM. THREM, RAREM,PBZIOR, PCPSREM, TLREM

REAL SBREM, ASREM, BEREM, CDREM,CRREM, CUREM, FEREM, PBREM, MGREM, MNREM, -HGREM, NI REM. SEREM. AGREM, ZNREM. UREM, THREM, PBC IOR WRI TE $(2,2001) 0, P C W A S T E, O C L E A N$

2001 FORMAT $(1 X$, TOTAL INPUT COAL: * IX,EI2.5

- IOX. *FRACTION COAL REMOVAL: *, IX,FG.4, IOX."TOTAL CLEAN COAL.

$-,(X, E[2.5)$

WRI ITE ( 2,2002$)$

2002 FORMAT ( IX, "CONST ITUENT *, T20, "FRACT ION REMOVED*, T40. "INPUT COAL*, -T60, *CLEAN COAL * T80, "STREAMI* , TIO0, +STREAME*"

$-1 \mathrm{X}, \mathrm{i}(1+-*), \mathrm{T} 20,16(*-*), T 40,10(*-*), T 60,10(*+)$, TBO , $-7(*-1, T 100,7(*) / 1)$

WRI TE $(2,2004)$ PCASHR, OCOAL $(1), \operatorname{COAL}(1)$, STREAM) (1), STREAME ( 11 . -ORGSREM, OCOAL (2), COAL (2), STREAMI $(2)$, STREAM2 $(2)$,

-SBKEM. OCOAL ( 3 ), COAL (3), STREAM) (3), STREAMZ (3).

-ASREM, OCOAL ( 4 ), COAL (4), STREAM1 (4), STREAM2 (4) 
2004 FORMAT ( IX.*ASH* .T20,El2.5.T40,E!2.5,T60,E!2.5, T80,E!2.5. -T100,El2.5/1X. +TOTAL SULFUR - T20.E12.5, T40.E12.5. T60.E12.5.

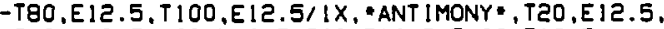
$-T 40, E 12.5, T 60 . E 12,5, T 80, E 12,5, T 100, E 12.51$ $-1 X, * A R S E N I C *, T 20, E J 2.5, T 40, E 12.5 . T 60, E I 2,5, T 80, E 12.5 . T 100, E 12.5$ $-1$

WR I TE ( 2,2005 I BEREM, OCOAL (5), COAL (5), STREAM1 (5), STREAM2 (5), -CDREM, OCOAL (6), COAL (6), STREAMI (6), STREAM2 (6), -CRREM, OCOAL $(7)$, COAL $(7)$, STREAMI $(7)$, STREAMZ (7). -CUREM OCOAL ( 8 ) COAL ( 8 ) STREAMI ( 8 ) STREAMZ $(8)$

2005 FORMAT IIX, *BERYLLIUM*, T20,EI2.5,4(8X,E 12.5$)$ )

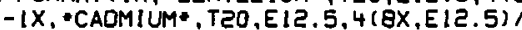

- IX, *CHROMIUM* T2D,E12.5,4(8X,E12.5)/

- (X, -COPPER*,T20,E $12.5,4(8 X, E 12.5)\}$

WRI TE (2.2006) FEREM,OCOAL ( 9 ), COAL ( 9 ), STREAMI ( 9 ), STREAM2 ( 9 ), -PBREM, OCOAL $(10)$, COAL $(10)$, STREAMI $(10)$, STREAM2 $(10)$. -MGREM, OCOAL $(11)$, COAL $(11)$, STREAMI $(11)$, STREAM2 $(11)$, -MNREM OCOAL (12), COAL ( 12 ) , STREAMI ( 12 ) STREAM2 ( 12 )

2006 FORMAT (IX.・IRON , T20.EI2.5.4(8X,EI2.5)

$-1 X, " L E A D *, T 20, E 12.5,4(8 X, E ! 2.5)$ )

- IX, -MAGNES [UM*, T20,EI2.5,4(8X,E12.5)/

- IX, -MANGANESE *,T20,EI2.5,4(8X,E) 2.5$)$ )

WRI TE (2, 2007) HGREM, OCOAL (13), COAL ( 13 ), STREAMI ( 13 ), STREAM2 ( 13 ). -NIREM, OCOAL (14), COAL ( 14), STREAMI (14), STREAM2 ( 14 ), -SEREM, OCOAL ( 15), COAL ( 15), STREAMI ( 15), STREAM2 (15). -AGREM, OCOAL (16), COAL (16), STREAMI (16), STREAMZ (16)

2007 FORMAT (IX, *MERCURY*,T20,E12.5,4(8X,EI2.5) )

$-1 X$, NICKEL*.T20,EI2.5,4(8X,E)2.5)/

-1X. SELENIUM*, T2O,EI2.5.4(BX,EI2,5)/

- IX,.SILVER*,T20,EI2.5,4(8X,EI2.5))

WR I TE (2.2018) TLREM.OCOAL ( 17), COAL (17), STREAM1 (17), STREAM2 (17), -ZNREM.OCOAL ( 18$),$ COAL $(18)$. STREAMI (18), STREAM2 (18). -UREM, OCOAL ( 19$)$, COAL (19), STREAMI ( 19$)$, STREAM2 ( 19 ).

-THREM, OCOAL (20), COAL (20), STREAMI (20), STREAM2 (20)

2018 FORMAT ( $1 X$, *THALLIUM*, T20,E12.5,4(8X,EI2.5)/

$-1 X,-Z I N C \cdot, T 20, E I 2.5,4(8 X, E 12.5) /$

-1X. -URANIUM*, T20,EI2.5,4(8X,EI2.5)/

$-1 X$. THOR IUM*,T20,E IZ.5,4(BX,EIZ.5))

WIRI TE ( 2,2008$)$ RAREM, OCOAL ( 21$),$ COAL (21) , STREAMI ( 21$)$, STREAM2 ( 21$)$. -RAREM, OCOAL (22), COAL (22), STREAMI (22), STREAM2 (22), -PB2 IOR, OCOAL (23), COAL (23), STREAMI (23), STREAM2 (23), -OCOAL (24), COAL (24), STREAMI (24), STREAM2 (24)

2008 FORMAT (1X, *RADIUM-226*,T20,E12.5.4(8X.E12.5)/

-IX.RADIUM-228*,T20,E12.5,4(8X,EI2.5)/

$-1 X$. LEAD-210*.T20,E12.5,4(8X,E12.5)1

- IX.*HYDROCARBONS . T40,EI2.5.3(BX.E12.5))

WRI TE (2, 2009) PCWASTE, OCOAL (25), COAL (25) , STREAMI (25), STREAM2 (25)

2009 FORMAT(IX. -TOTAL SOLID WASTE*, T20.EI2.5.4(8X,EI2.5)) $J=0$

C WRITE $(2,2010)(J, O C O A L(1), \operatorname{COAL}(1), \operatorname{STREAM} 1$ (1), STREAM2 (1), I =26, 33)

2010 FORMAT 11 . *NOT APPL ICABLE*, T20,E I2.5,4(8X,EI2.5)) WRI TE ( 2,2011 ) OCOAL (34), COAL (34) STREAMI (34) , STREAM2 ( 34 )

2011 FORMAT (IX. "WATER*, T40,E12.5,3(8X,E12.5))

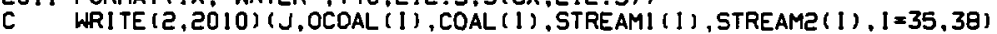
WR I TE (2, 20 12) PCPSREM, OCOAL ( 39 ), COAL (39), STREAMI ( 39 ), STREAM2 (39) - GTUREM, OCOAL (40), COAL (40), STREAMI ( 40 ), STREAM2 (40), -GTUREM, OCOAL $(41)$, COAL ( 41$)$, STREAMI $(41)$, STREAM2 $(41)$

2012 FORMAT (IX.*PYRITIC SULFUR*,T20,EI2,5,4(BX,EI2.5)/

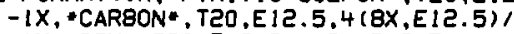

- (X, -QTU*, T20,EI2.5,4(BX,EI2.5)\}

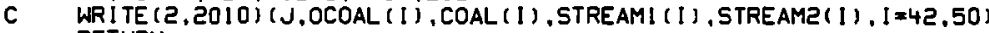
RETURN

END 


\begin{tabular}{|c|c|c|c|c|c|}
\hline $\begin{array}{l}\text { TOTAL INPUT COAL: } \\
\text { FRACTION } \\
\text { CONST I TUENT }\end{array}$ & $\begin{array}{l}\text { COOAOOE+06 } \\
\text { FOAL REMOVAL: } 1918 \\
\text { FRACIION REMOVED }\end{array}$ & INPUT COAL TOTAL & $\begin{array}{l}\text { CLEAN COAL } \\
\text { CLEAN COAL } \\
.873 \\
\end{array}$ & $\begin{array}{l}\text { +0E+05 } \\
\text { STREAMI }\end{array}$ & STREAME \\
\hline $\begin{array}{l}\text { ASH } \\
\text { TOTAL SULFUR } \\
\text { ANTIMONY } \\
\text { ARSENIC } \\
\text { BERYL IUM } \\
\text { CADMIUM } \\
\text { CHROMIUM } \\
\text { COPPER } \\
\text { IRON } \\
\text { LEAD } \\
\text { MAGNESIUM } \\
\text { MANGANESE } \\
\text { MERCURY } \\
\text { NICKEL } \\
\text { SELENIUM } \\
\text { SILVER } \\
\text { THALLIUM } \\
\text { ZINC } \\
\text { URANIUM } \\
\text { THORIUM } \\
\text { RADIUM-2Z6 } \\
\text { RAD:UM-2Z8 } \\
\text { LEAD-2IO } \\
\text { HYDROCARBONS } \\
\text { TOTAL SOL ID WASTE } \\
\text { WATER } \\
\text { PYRI TIC SULFUR } \\
\text { CAREON } \\
\text { BTU }\end{array}$ & $\begin{array}{l}.58190 E+00 \\
.10600 E+00 \\
.15000 E+00 \\
.58190 E+00 \\
.20278 E+00 \\
.26806 E+00 \\
.36072 E+00 \\
.39999 E+00 \\
.43149 E+00 \\
.58190 E+00 \\
.30000 E+00 \\
.43149 E+00 \\
.58190 E+00 \\
.35264 E+00 \\
.37033 E+00 \\
.27601 E+00 \\
0 . \\
.43149 E+00 \\
.20995 E+00 \\
.20995 E+00 \\
.58190 E+00 \\
.58190 E+00 \\
.58190 E+00 \\
.19181 E+00 \\
.43149 E+00 \\
.10600 E+00 \\
.10600 E+00\end{array}$ & $\begin{array}{l}18700 E+05 \\
.30000 E+04 \\
.70000 E-01 \\
.27000 E+01 \\
.50000 E+00 \\
.12500 E+00 \\
.30000 E+01 \\
.11800 E+01 \\
.27000 E+04 \\
.11400 E+01 \\
.11800 E+03 \\
.74000 E+01 \\
.17000 E-01 \\
.20000 E+01 \\
.20000 E-01 \\
.10000 E-01 \\
.10000 E+01 \\
.16900 E+01 \\
.70000 E-01 \\
.66000 E+00 \\
.23660 E-07 \\
.26466 E-09 \\
.30590 E-09 \\
0 . \\
0 . \\
0 . \\
.18700 E+04 \\
.64100 E+05 \\
.23000 E+13\end{array}$ & $\begin{array}{l}.11518 E+05 \\
.23884 E+04 \\
.63070 E-01 \\
.16531 E+01 \\
.43308 E+00 \\
.10298 E+00 \\
.22858 E+01 \\
.87706 E+00 \\
.19311 E+04 \\
.70218 E+00 \\
.94636 E+02 \\
.52926 E+01 \\
.10471 E-01 \\
.15345 E+01 \\
.15112 E-01 \\
.81783 E-02 \\
.10000 E+01 \\
.12087 E+01 \\
.60300 E-01 \\
.56855 E+00 \\
.14573 E-07 \\
.16302 E-09 \\
.18842 E-09 \\
0 . \\
0 . \\
0.13375 E+04 \\
.13375 E+04 \\
.59616 E+05 \\
.21391 E+13\end{array}$ & $\begin{array}{l}.70022 E+04 \\
.59631 E+03 \\
.67567 E-02 \\
.101110 E+01 \\
.65244 E-01 \\
.21562 E-01 \\
.69637 E+00 \\
.29537 E+00 \\
.74969 E+03 \\
.42687 E+00 \\
.22790 E+02 \\
.20547 E+01 \\
.63657 E-02 \\
.45385 E+00 \\
.47662 E-02 \\
.17761 E-02 \\
0.14925 E+00 \\
.46925 E+00 \\
.94572 E-02 \\
.89168 E-01 \\
.88595 E-08 \\
.99102 E-10 \\
.11454 E-09 \\
0 . \\
.12398 E+05 \\
.10237 E+04 \\
.51923 E+03 \\
.43723 E+04 \\
0 .\end{array}$ & $\begin{array}{r}.17954 E+03 \\
.15290 E+02 \\
.17325 E-03 \\
.25924 E-01 \\
.16729 E-02 \\
.55288 E-03 \\
.17856 E-01 \\
.75736 E-02 \\
.19223 E+02 \\
.10946 E-01 \\
.58410 E+00 \\
.52685 E-01 \\
16322 E-03 \\
.11637 E-01 \\
.12221 E-03 \\
.45542 E-04 \\
0 . \\
.12032 E-01 \\
.24249 E-03 \\
.22864 E-02 \\
.22717 E-09 \\
.25411 E-11 \\
.29370 E-11 \\
0.11 \\
.34999 E+03 \\
.58331 E+02 \\
.13314 E+02 \\
.112111 E+03 \\
0 .\end{array}$ \\
\hline
\end{tabular}


2 SOLID WASTE MODULE FOR COAL COMBUSTION IN A CONVENTIONAL BOILER

\subsection{Introduction}

The largest volume of solid waste from energy industries currently and expected in the near future comes from conventional coal combustion. Increasingly stringent air regulations will require all new coal-fired power plants to employ flue gas desulfurization (FGD) processes to remove $\mathrm{SO}_{2}$, and this will greatly increase the quantities of waste produced.

\subsection{General Description of Solid Waste from Coal Combustion}

Two types of ash are produced during combustion, fly ash consisting of the fine particles that are entrained in the flue gas stream, and bottom ash which is the coarser, heavier residue accumulated at the furnace bottom. The distribution of ash between bottom ash and fly ash fraction is a function of boller type (firing method). Stoker fuel units emit the smallest proportion of fly ash, $\sim 10 \%$. In cyclone units, $\sim 60 \%$ appears as fly ash; for other pulverized bollers (most commonly used by ut1lities) the split is $80 \%$ fly ash and $20 \%$ bottom ash.

In all cases utflity and industrial bollers employ some form of precipitator to collect a proportion of the fly ash. The efficlency of the collection device and hence the amount of fly ash solid waste is highly variable. Depending on air regulations governing a particular facility, an FGD system may be needed.

The removal of $\mathrm{SO}_{2}$ by means of scrubbers is accomplished by two general processes - throwaway and regenerable. The first type refers to those flue gas desulfurization scrubbers that produce a solld waste stream not presently 
marketable and requiring disposal. The most common example is a lime/limestone scrubber which uses calcium salts to absorb $\mathrm{SO}_{2}$ in solution.

Regenerable scrubber systems are those which, because of their specific chemical reactions, produce a marketable product of sulfur and regenerate the sorbent which can be reused. Some common examples of regenerable processes are the Wellman-Lord sulfite and the magnesiun oxide processes, both of which produce a usable sulfur product, such as solid elemental sulfur, 1iquid sulfuric acid, or highly concentrated $\mathrm{SO}_{2}$ gas.

The throwaway systems may be elther wet or dry. The wet scrubbing systems employ a slurry of either lime or limestone to remove the $\mathrm{SO}_{2}$ and produce a waste consisting of calcium sulfate, calcium sulfite, and unreacted 11mestone. The major dry systems are a spray drier or dry injection. In the spray drier, the flue gas is contacted with a calcium-based slurry or sodium solution such that the gas is evaporated to apparent dryness. The dry Injection system involves the introduction of a dry sorbent, the most promising being nahcolite (sodium bicarbonate), into the flue gas. The resulting waste, consisting of a dry mixture of sodiun or calciun sulfite and sulfate, is collected by a baghouse precipitator. A major difference between the dry and wet systems is that in the majority of wet systems, the ash is collected by a precipitator prior to the scrubber, whereas in the dry systems the ash and scrubbing waste are collected together.

The wet throwaway processes are at present preferred by the utillties for several reasons including lower capltal costs, avallability and ease of use of sorbent and relative simplicity. But they have the major disadvantage of producing large amounts of waste. No dry systems are operating now 
commercially. The dry systems do not at present achieve as high a degree of $\mathrm{SO}_{2}$ removal as do the wet systems.

\subsection{Overal1 Module Description}

The module computes the air and solid waste residuals which result from the combustion of coal in a conventional utility or Industrial boiler. The input to the module is the quantity of coal and its composition in terms of sulfur, ash, and trace element content. The module employs a mass balance approach to compute the distribution of the sulfur, ash, and trace elements in the coal between the air and solid waste residuals. Figure 2.1 gives an overall view of the module.

The module calculates the air and solld waste residuals for four types of boiler:

General pulverized utility and large industrial boiler $(>100 \mathrm{~m} \mathrm{Btu} / \mathrm{hr})$

Cyclone utility and large industrial boller ( $>100 \mathrm{~m} \mathrm{Btu/hr)}$

Large industrial pulverized boller (10 to $100 \mathrm{~m} \mathrm{Btu/hr)}$

Small industrlal stoker boller ( $<10 \mathrm{~m} \mathrm{Btu/hr)}$

An input variable determines which boller is to be used.

A chotce is then made as to the control mechanisms to be employed. A switch is set to determine whether the plant uses a precipitator to collect particulates efther alone or followed by a $\mathrm{FGD}$ system to remove $\mathrm{SO}_{2}$, or the plant employs only a FGD system to remove both $\mathrm{SO}_{2}$ and particulates. At present the module considers only one generic type of precipitator, as there are not enough data available to assess what effect different systems (e.g., electrostatic precipitator or baghouse) have on trace element removal. The module could easily be expanded to include different devices. Both 


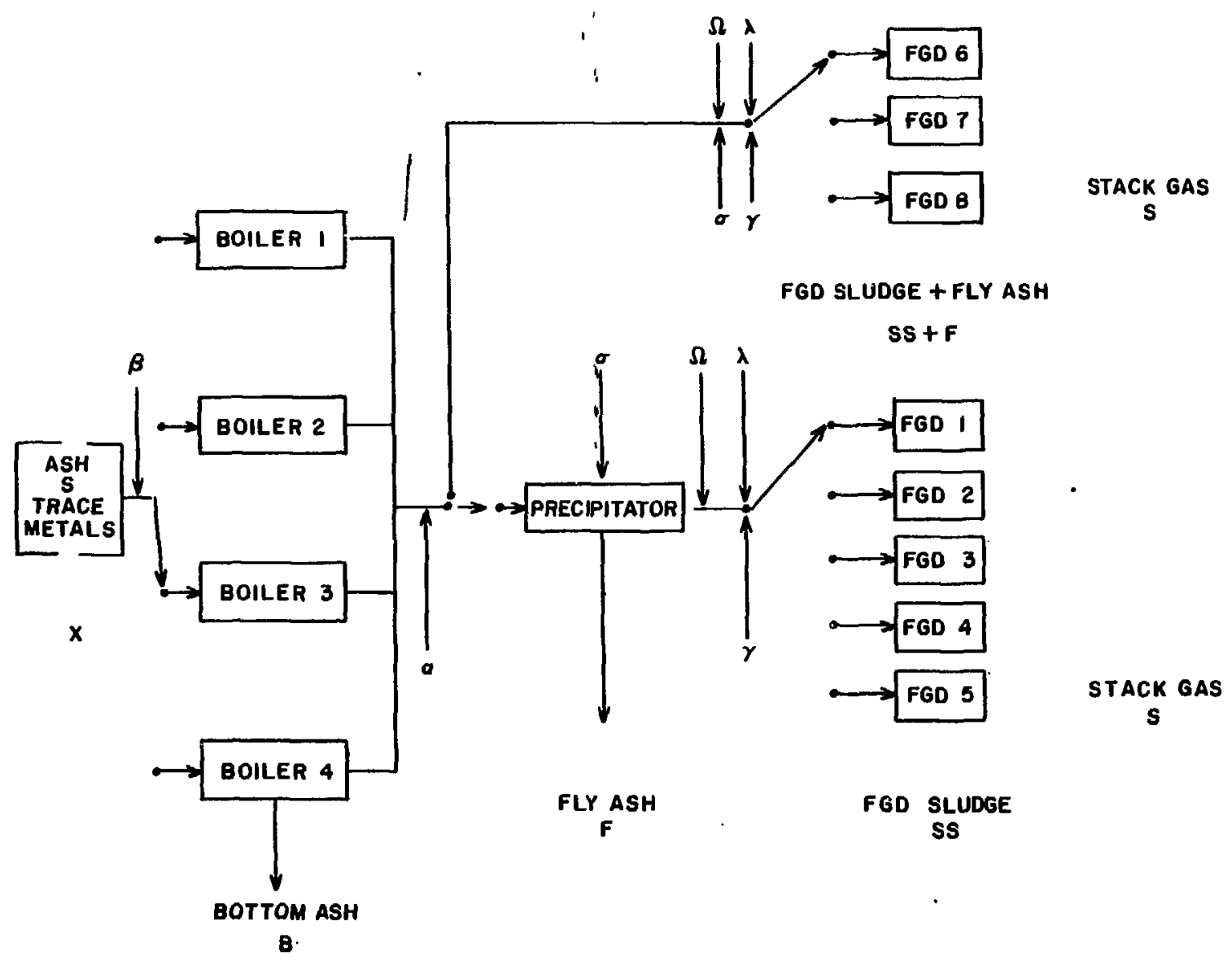

Figure 2.1. Overall conventional combustion module design. 


\section{Notation for Figure 2.1}

\section{Inputs}

X Coal characteristics

B Bo1ler type

a Removal equl pment used

a. Precipitator followed by an FGD system

b. FGD system only

$\sigma \quad$ Percentage removal of TSP

$\Omega \quad$ Percentage removal of $\mathrm{SO}_{2}$

$\lambda \quad$ Type of FGD system

$\gamma \quad$ Trace metal content of the scrubbing media

Outputs

B Amount and composition of bottom ash

F Amount and composition of fly ash

SS Amount and composition of FGD sludge

S Composition of stack gases 
particulate and trace metal removals are given as a function of the efficlency. of the precipitator. Any reasonable precipitator efficiency can be used; this Is specified as an input variable.

The module uses 3 wet and 1 dry nonregenerable systems and 2 regenerable processes. The dry system used is injection of nahcolite into the flue gas followed by baghouse collection. The particulates are also removed in. the baghouse.

Nonregenerable Systems:

Lime wet scrubbing.

Limestone wet scrubbing.

Double alkall wet scrubbing.

Dry sorbent injection.

\section{Regenersble Systems:}

Wellman-Lord sulfite scrubbing.

Magnesta slurry absorption.

If, however, a wet FGD system is to be used to remove both $\mathrm{SO}_{2}$ and particulates, only a wet lime or limestone scrubber is considered. The dry FGD system also removes $\mathrm{SO}_{2}$ and particulates. A switch is also set to determine the type of FGD system to be employed:

1. Precipitator followed by lime scrubber.

2. Precipitator followed by limestone scrubber.

3. Precipitator followed by double-alkali.

4. Precipitator followed by magnesium-oxide.

5. Precipitator followed by Wellman-Lord.

6. Lime scrubber only.

7. Limestone scrubber only.

8. Dry sorbent injection.

9. Precipitator only. No FGD system. 
The module is called as a subroutine with the following arguments:

Input vector of coal characteristics.

Output vector of bottom ash composition.

Output vector of fly ash composition.

Output vector of FGD sludge composition.

Output vector of stack gas composition.

Type of boiler. Input integer number from

1 to 4 corresponding to the type of bollers

given on page 57.

Is a precipitator used or not? Input integer

number, 1 or 0 respectively.

Type of FGD system. Input integer number from

1 to 9 corresponding to the types shown on page 60 .

Input real number giving percentage removal of $\mathrm{SO}_{2}$.

Input real number glving percentage removal of

particulates.

Input quantity of coal.

To facilitate computation, the first 5 arguments are vectors which contain the same number of elements. These elements are given in Table 2.1. In all cases the elements are given as quantitites. Depending on which vector is being considered, a number of the elements will have zero values.

For radionuclides, data are, at present, only generally avallable for the input quantities of uranium and thorium. However, the masses of radium-226 and lead-210 can be calculated from the mass of urantun-238 and the mass of raditm-228 from thortim-232. The equations and assumptions used in the calculation are glven in Section 7. 
Table 2.1

Elements

\begin{tabular}{|c|c|c|c|}
\hline Number & Type & Number & Type \\
\hline 1 & Ash & 24 & Hydrocarbons \\
\hline 2 & Sulfur (S) & 25 & Total solid waste \\
\hline 3 & Antimony (Sb) & 26 & Unreacted limestone \\
\hline 4 & Arsenic (As) & 27 & Calctum sulfite \\
\hline 5 & Beryllium (Be) & 28 & Calcium sulfate \\
\hline 6 & Cadmi un (Cd) & 29 & Soda-ash \\
\hline 7 & Chromi un (Cr) & 30 & Magnesi um sulfite \\
\hline 8 & Copper (Cu) & 31 & Magnestum oxide \\
\hline 9 & Iron (Fe) & 32 & Sodium bisulfite \\
\hline 10 & Lead $(\mathrm{Pb})$ & 33 & Sodtum sulfite \\
\hline 11 & Magnesi um (Mg) & 34 & Water \\
\hline 12 & Manganese (Mn) & 35 & Sulfur dioxide \\
\hline 13 & Mercury (Hg) & 36 & Nitrous oxides \\
\hline 14 & Nickel (Ni) & 37 & Carbon monoxide \\
\hline 15 & Selenium (Se) & 38 & Methane \\
\hline 16 & Silver (Ag) & 39 & Pyritic sulfur \\
\hline 17 & Thallium (T1) & 40 & Carbon \\
\hline 18 & Zinc (Zn) & 41 & Btu \\
\hline 19 & Urani um-238（U) & 42 & Carbon dioxide \\
\hline 20 & Thor 1 um-232 (Th) & 43 & Sodium bicarbonate \\
\hline 21 & Radium-226 (Ra) & 44 & Sudium carbonate \\
\hline 22 & Radi um-228（Ra） & 45 & Sodlum sulfate \\
\hline \multirow[t]{2}{*}{23} & Lead-210 (Pb) & 46 & Calciun carbonate \\
\hline & & 47 & Calcium oxide \\
\hline
\end{tabular}




\subsection{Description of Botler Residuals}

Depending on the type of boller used, the elements of the Input coal characteristics vector are multiplied by different sets of coefficlents to give the quantity of each element which goes up the stack in the flue gas or fly ash. Table 2.2 glves the coefficlents used. The coefficlents are contalned in external data files, and the values can therefore be easily changed as better data become avallable.

The flgures for ash and sulfur are taken from Reference 1, with the exception of the coefficient for ash for cyclone utility boilers, which comes from References 2 to 5. The figure for carbon is taken from Reference 14. A number of reports were studied to obtain coefficients for the trace elements.2-7 Reference 2 gives the results of trace metal distribution for two pulverized and one cyclone utility bollers. References 3 to 5 are all part of the same project undertaken by Oak RIdge National Laboratory to study the fate of trace elements at the Allen Plant which has a cyclone boiler. Figures from Reference 5 were used as this gives two sets of results for runs undertaken in 1972 and 1973. Reference 6 looked at trace element distribution at the Widows Creek Plant which has a pulverlzed boller. Unfortunately, the report contains some rather spurfous results for the split between bottom and fly ash, probably because there is a superheater, after the main boiler and before the precipitator, from which ash is collected. It was therefore decided not to include the results in the calculation of the coefficients. Reference 7 was a study of the Valmont Power Plant which uses a pulverized boiler. Again, the results could not be used in the calculation of the coefficients, because complete sets of results were avallable for only five of the trace elements and, of these, two had very poor mass balances. 
Table 2.2

Boiler Coefficients for Fraction of the Incoming Element which Goes Up the Stack

\begin{tabular}{|c|c|c|c|c|}
\hline Input Element & $\begin{array}{l}\text { Boiler } 1 \\
\text { Pulverized } \\
>100 \mathrm{~m} \\
\text { Bt u/hr }\end{array}$ & $\begin{array}{l}\text { Boiler } 2 \\
\text { Cyclone } \\
>100 \mathrm{~m} \\
\text { Btu/hr }\end{array}$ & $\begin{array}{l}\text { Boiler } 3 \\
\text { Pulverized } \\
10-100 \mathrm{~m} \\
\text { Bt u/hr }\end{array}$ & $\begin{array}{l}\text { Boller } 4 \\
\text { Stoker } \\
<10 \mathrm{~m} \\
\text { Btu/hr } \\
\end{array}$ \\
\hline Ash & 0.80 & 0.40 & 0.65 & 0.10 \\
\hline Sulfur & 0.95 & 0.95 & 0.95 & 0.95 \\
\hline Antimony & 0.9483 & 0.9166 & 0.9483 & 0.9166 \\
\hline Arsenic & 0.98 & 0.8271 & 0.98 & 0.8271 \\
\hline Bery11ium & 0.8371 & 0.418 & 0.8371 & 0.418 \\
\hline Cadmi um & 0.8818 & 0.8144 & 0.8818 & 0.8144 \\
\hline Chromi um & 0.878 & 0.5415 & 0.878 & 0.5415 \\
\hline Copper & 0.8745 & 0.6892 & 0.8745 & 0.6892 \\
\hline Iron & 0.7614 & 0.3946 & 0.7614 & 0.3946 \\
\hline Lead & 0.9435 & 0.9256 & 0.9435 & 0.9256 \\
\hline Magnesium & 0.8255 & 0.3786 & 0.8255 & 0.3786 \\
\hline Manganese & 0.8466 & 0.3722 & 0.8466 & 0.3722 \\
\hline Mercury & 0.9872 & 0.9877 & 0.9872 & 0.9877 \\
\hline Nickel & 0.8422 & 0.7377 & 0.8422 & 0.7377 \\
\hline Selenium & 0.9882 & 0.8066 & 0.9882 & 0.8066 \\
\hline Silver & 0.9449 & 0.78 & 0.9449 & 0.078 \\
\hline Thalliun & 0.8807 & 0.9739 & 0.8807 & 0.9739 \\
\hline Zinc & 0.8863 & 0.9288 & 0.8863 & 0.9288 \\
\hline Urani um-238 & 0.6997 & 0.5424 & 0.6997 & 0.5424 \\
\hline Thori um-232 & 0.8019 & 0.3874 & 0.8019 & 0.3874 \\
\hline Radilum-226 & 0.80 & 0.40 & 0.65 & 0.10 \\
\hline Radi um-228 & 0.80 & 0.40 & 0.65 & 0.10 \\
\hline Lead-210 & 0.9435 & 0.9256 & 0.9435 & 0.9256 \\
\hline Carbon & 0.98 & 0.98 & 0.98 & 0.98 \\
\hline
\end{tabular}


The coefficlents for pulverized bollers were calculated from two sets of figures given in Reference 2. In all the studies, there was variability between elements as to how good the total mass balances were. In general, considering the experimental difficulties that must have arisen, the results are not too bad and in many cases the overall mass balances were reasonably close to unity. In order to calculate coefficlents, the percentage splits between bottom and fly ash were normalized to give an overall mass balance of 100\%. A geometric mean was then taken of the two sets of figures to give overall coefficlents to calculate the fraction of the incoming element which goes up the stack in a pulverized boller.

For the cyclone boller, the two sets of results in Reference 5 and the figures for the cyclone boiler in Reference 2 were used. Again, the figures were normalized to give a mass balance of $100 \%$ and geometric means were taken.

Full detalls of the figures and calculations used are given in Appendix 2A. The figures clearly contalned some analytical errors. Also, for some elements there were large variations in the results obtained by different teams and, In the case of the Oak Ridge Profect, between different years. To produce good coefficlents, additional experimental work is needed and as data beccine available the figures should be reviewed.

For $\mathrm{Pb} 210$ the same coefficients are used as for the nonradioactive isotope. Reference 12 indicated that for radiun there is no significant enrichment or depletion in the bottom ash. It was therefore assumed that the split is the same as for the overall ash.

In particular, there were no avallable data on the trace metal distributions for medium and small industrial bollers. It was assumed that, 
based on the bottom to fly ash split, the medium-sized industrial boiler behaved more like the large pulverlzed boiler and the small industrlal boller like the cyclone boiler. The relevant sets of coefficients for trace elements were therefore used.

This is clearly unsatisfactory and the coefficients should be recalculated as soon as data become avallable.

The quantity of each element in the bottom ash is calculated by subtracting the quantity going up the stack from the original input quantity. This gives the output vector for bottom ash. The element named ash in this case refers to the total quantity of dry botton ash.

After the amounts of sulfur and carbon in the bottom ash have been calculated, the remaining sulfur in the stack gas is converted to $\mathrm{SO}_{2}$ by multiplying by 2 and the carbon to $\mathrm{CO}_{2}$ by multiplying by 3.67 . The output quantities then appear under element 35 , sulfur dioxide, and element 42 , carbon dioxide. Elements 35 to 37 are the gaseous pollutants, $\mathrm{NO}_{2}, \mathrm{CO}$, and $\mathrm{CH}_{4}$, which are formed in the combustion process and appear in the final stack gas. They are calculated by multiplying the quantity of input coal by a set of coefficients, which again depend on the boller type. The coefficients come from Reference 1 and are given in Table 2.3. This procedure does lead to a double counting of the carbon, but the fraction appearing as $\mathrm{CO}$ and $\mathrm{CH}_{4}$ is very small compared to the $\mathrm{CO}_{2}$ -

\subsection{Description of Precipitator Residuals}

The composition of the stack gas from the boiler is used as an input to the precipitator. The efficlency of the precipitator, as a percentage, is given as an input varlable. 
Table 2.3

Coefficients for Calculation of Air Emissions

\begin{tabular}{|c|c|c|c|c|}
\hline \multirow[b]{2}{*}{ Pollutant } & \multicolumn{4}{|c|}{ Emission Coefficients (tons/ton input coal) } \\
\hline & $\begin{array}{l}\text { Boiler } 1 \\
\text { Pulverized } \\
>100 \mathrm{~m} \text { Bt } \mathrm{u} / \mathrm{hr}\end{array}$ & $\begin{array}{l}\text { Boller } 2 \\
\text { Cyclone } \\
>100 \mathrm{~m} \text { Btu/hr }\end{array}$ & $\begin{array}{l}\text { Boller } 3 \\
\text { Pulverized } \\
\text { 10-100m Btu/hr }\end{array}$ & $\begin{array}{l}\text { Boller } 4 \\
\text { Stoker } \\
\text { <10m Btu/hr }\end{array}$ \\
\hline $\mathrm{NO}_{2}$ & $9.0 \times 10^{-3}$ & $2.75 \times 10^{-2}$ & $7.5 \times 10^{-3}$ & $3.0 \times 10^{-3}$ \\
\hline co & $5.0 \times 10^{-4}$ & $5.0 \times 10^{-4}$ & $1.0 \times 10^{-3}$ & $5.0 \times 10^{-3}$ \\
\hline $\mathrm{CH}_{4}$ & $1.5 \times 10^{-4}$ & $1.5 \times 10^{-4}$ & $5.0 \times 10^{-4}$ & $1.5 \times 10^{-3}$ \\
\hline
\end{tabular}

In other studies, the emission coefficients for trace metals have been calculated as being independent of the precipitator efficiency, which is clearly incorrect. In this module, attempts have been made to determine the quantity of each trace element passing through a precipitator as a function of the precipitator efficiency.

The measurements given in Reference 5 and stations II and III from Reference 2 were from bollers fitted with precipitators of differing efficlencles. For all results the percentage of the element passing through the precipitator was calculated. These figures could then be compared with the general pass-through of the fly ash. Table 2A.12, Appendix 2A, gives the results. In some cases the pass-through varied in a linear fashion with the Increasing precipitator efficiency (e.g., Iron and magnesium). In other cases a nonlinear function was found to better fit the points (e.g., arsenic, thorium). Table 2.4 gives the coefficients.

In some cases the coefficients are thought to be reasonably good (e.g., Iron and manganese). However, for others the data were either not available or appeared spurlous which leads to a low degree of confidence in the coefficient (e.8., lead, arsenic, and selenium). A full discussion of the 


\section{Table 2.4}

Coefficients to Calculate the Function of a Trace Element Passing Through a Precipitator

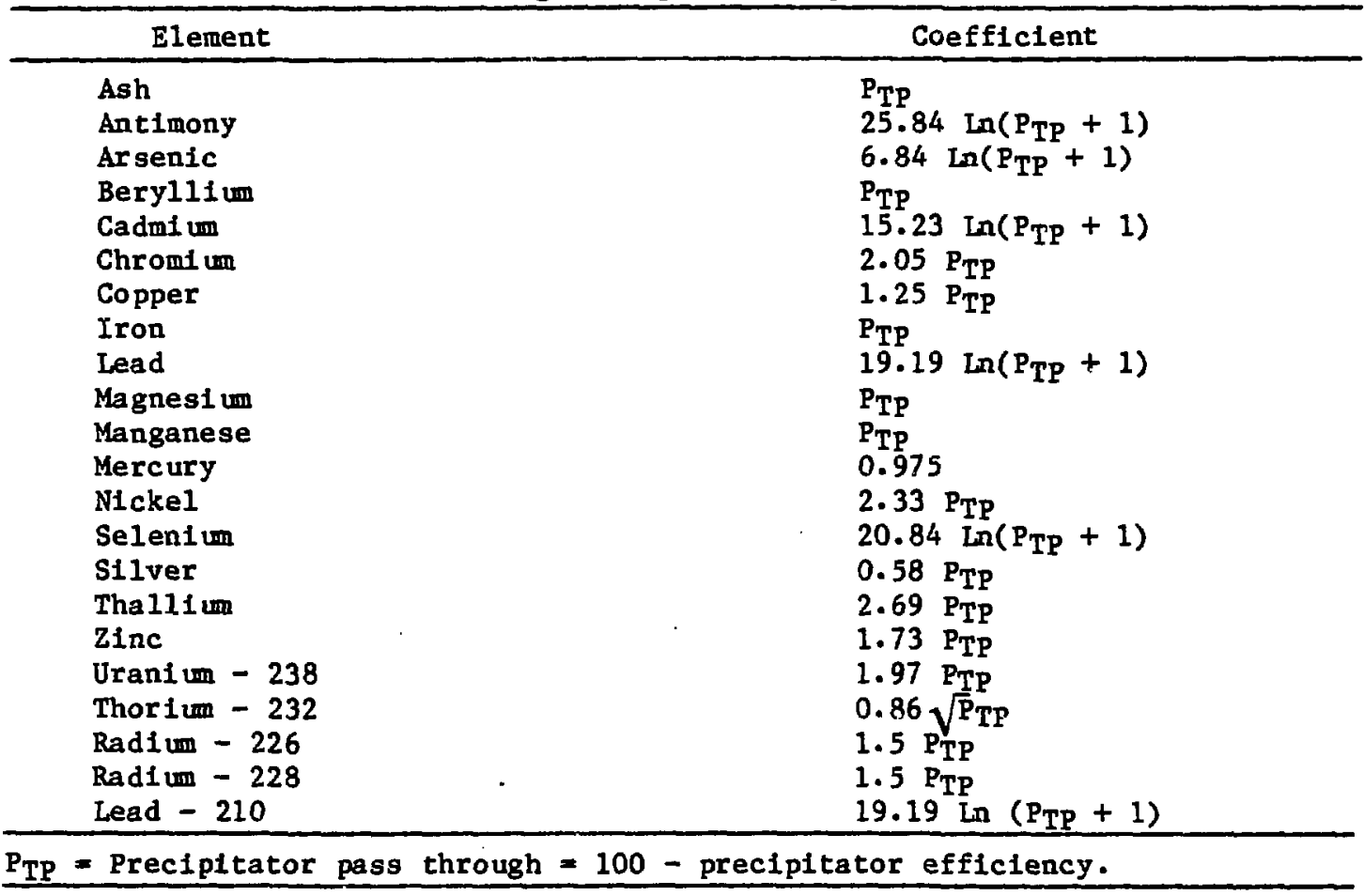

calculations and assumptions behind the coefficlents is given in Appendix $2 \mathrm{~A}$ together with a discussion of the degree of confidence in the accuracy of each coefficient. Clearly more data are required to enable the calculation of more reliable coefficients.

The quantity of each element in the fly ash is calculated by subtracting the quantity going out the stack after the precipitator from the input quantity into the precipitator. This gives the output vector for fly ash. The element named ash in this case refers to the total quantity of dry fly ash. 
2.6 Description of FGD Residuals when the FGD Follows a Precipitator

The composition of the stack gas from the precipitator is used as an input to the FGD system. The switch determining which particular type of FGD system and its efficlency in terms of $\mathrm{SO}_{2}$ removal are given as input variables.

Major Components. Although most of the particulates will have been removed prior to the FGD system, a small percentage will go into and be captured by the FGD unit. The total quantity of solid waste produced (element 25) Is therefore the total quantity of FGD sludge plus the captured fly ash. This is given as the wet quantity. The individual components which make up total solid waste, element 1 (ash) and elements 26 to 33 (FGD sludge compounds) are given as dry weights. Element 34 (water) is the total amount of water (in tons) that is included in the total iet solid waste. The quantities of FGD scrubber sludge vary even within the same type of FGD process because of differences in working conditions. The equations used inciude varlables which reflect these differences. At present, however, there are not many data available and default values have been substituted which reduces the equation to simple coefficients. The equations and assumptions used are given in Appendix 2B, and Table 2.5 sets out the coefficients used in the moduls.

Not many data were avallable to determine how much of the fly ash would be captured by the FGD system. From Reference 9 (pp. 4-45), figures were obtained which gave the percentage pass-through of fly ash as a function of Input concentration. This showed that the pass-through varted from $45 \%$ at very low input concentrations to $5 \%$ at very high input concentrations. 
Table 2.5

Coefficients to Calculate FGD Sludge and Its Major Components for Wet Scrubbing Systems

\begin{tabular}{|c|c|c|c|c|c|}
\hline \multirow[b]{2}{*}{ Component } & \multicolumn{5}{|c|}{ Coefficient } \\
\hline & $\begin{array}{l}\text { FGD1 } \\
\text { Lime }\end{array}$ & $\begin{array}{c}\text { FGD2 } \\
\text { Limestone }\end{array}$ & $\begin{array}{l}\text { FGD3 } \\
\text { Double- } \\
\text { Alkali }\end{array}$ & $\begin{array}{l}\text { FGD4 } \\
\text { Magnesium- } \\
\text { Oxide }\end{array}$ & $\begin{array}{c}\text { FGD5 } \\
\text { Wellman-Lord }\end{array}$ \\
\hline $\begin{array}{l}\text { Total FGD sludge (wet) } \\
\text { Unreacted IImestone (dry) } \\
\text { Calci un sulfate (dry) } \\
\text { Calciun sulfite (dry) } \\
\text { Magnesium oxide (dry) } \\
\text { Magnesium sulfite (dry) } \\
\text { Soda ash (dry) } \\
\text { Sodium bisulfite (dry) } \\
\text { Sodi un sulfite (dry) }\end{array}$ & $\begin{array}{l}4.728 \mathrm{SO}_{2} \\
0.174 \mathrm{SO}_{2} \\
0.674 \mathrm{SO}_{2} \\
1.516 \mathrm{SO}_{2} \\
\text { N/A } \\
\text { N/A } \\
\text { N/A } \\
\text { N/A } \\
\text { N/A }\end{array}$ & $\begin{array}{l}4.697 \mathrm{SO}_{2} \\
0.3525 \mathrm{SO}_{2} \\
0.631 \mathrm{SO}_{2} \\
1.365 \mathrm{SO}_{2} \\
\mathrm{~N} / \mathrm{A} \\
\mathrm{N} / \mathrm{A} \\
\mathrm{N} / \mathrm{A} \\
\mathrm{N} / \mathrm{A} \\
\mathrm{N} / \mathrm{A}\end{array}$ & $\begin{array}{l}4.6518 \mathrm{SO}_{2} \\
0.0829 \mathrm{SO}_{2} \\
0.675 \mathrm{SO}_{2} \\
1.518 \mathrm{SO}_{2} \\
\mathrm{~N} / \mathrm{A} \\
\mathrm{N} / \mathrm{A} \\
0.05 \mathrm{SO}_{2} \\
\mathrm{~N} / \mathrm{A} \\
\mathrm{N} / \mathrm{A}\end{array}$ & $\begin{array}{l}0.1539 \mathrm{SO}_{2} \\
\text { N/A } \\
\text { N/A } \\
\text { N/A } \\
0.01875 \mathrm{SO}_{2} \\
0.08125 \mathrm{SO}_{2} \\
\text { N/A } \\
\text { N/A } \\
\text { N/A }\end{array}$ & $\begin{array}{c}0.2158 \mathrm{SO}_{2} \\
\mathrm{~N} / \mathrm{A} \\
\mathrm{N} / \mathrm{A} \\
\mathrm{N} / \mathrm{A} \\
\mathrm{N} / \mathrm{A} \\
\mathrm{N} / \mathrm{A} \\
\mathrm{N} / \mathrm{A} \\
0.08125 \mathrm{SO}_{2} \\
0.059 \mathrm{SO}_{2}\end{array}$ \\
\hline $\begin{array}{ll}\mathrm{N} / \mathrm{A} & \text { Not appl } \\
\mathrm{SO}_{2} & \text { Quantity }\end{array}$ & $\begin{array}{l}\text { cable. } \\
\text { of captured }\end{array}$ & & & & \\
\hline
\end{tabular}

A plant having a prectpitator followed by an FGD system will be of recent construction and therefore will be subject to. high particulate controls. This will give a low concentration of fly ash into the FGD system. It was therefore decided that until better data become available, $65 \%$ of the incoming fly ash would be captured by the FGD system.

Outlet fly ash (dry) = Inlet fly ash $\cdot 0.65$.

This figure appears in the output vector as element 1 (ash). In the total solid waste (element 25), the quantity of wet fly ash is used.

Fly Ash $($ wet $)=$ Fly Ash (dry) $x \frac{100}{100-m}$,

where

m = molsture content. 
The value of $\mathrm{m}$ will be the same as for the FGD sludge:

$$
\begin{aligned}
& m=50 \% \text { for nonregenerable systems. } \\
& m=35 \% \text { for regenerable systems. }
\end{aligned}
$$

Total solld waste $=$ FGD sludge + fly ash (wet) .

Minor Components. Trace elements in the solid waste come from both the incoming combustion flue gas and the scrubbing media.

Trace Elements from Scrubblng Media. Table $2.6 \mathrm{glves}$ the average trace metal content of lime and limestone (welght fraction). These flgures are geometric averages of values given in References 8 and 10.

Table 2.6

Fraction of Trace Elements in Lime and Limestone

\begin{tabular}{lcc}
\hline Trace Element & Lime & Limestone \\
\hline Antimony & $\mathrm{N} / \mathrm{D}$ & $\mathrm{N} / \mathrm{D}$ \\
Arsenic & $1.5 \times 10^{-6}$ & $1.71 \times 10^{-6}$ \\
Beryllium & $1.8 \times 10^{-9}$ & $1.87 \times 10^{-7}$ \\
Cadmium & $3.372 \times 10^{-8}$ & $1.55 \times 10^{-7}$ \\
Chromium & $3.12 \times 10^{-6}$ & $8.14 \times 10^{-6}$ \\
Copper & $1.9 \times 10^{-6}$ & $1.69 \times 10^{-6}$ \\
Iron & $6.27 \times 10^{-8}$ & $6.27 \times 10^{-8}$ \\
Lead & $2.07 \times 10^{-7}$ & $1.29 \times 10^{-6}$ \\
Magnesium & $7.68 \times 10^{-3}$ & $7.68 \times 10^{-3}$ \\
Manganese & $1.55 \times 10^{-4}$ & $1.55 \times 10^{-4}$ \\
Mercury & $\mathrm{N} / \mathrm{D}$ & $\mathrm{N} / \mathrm{D}$ \\
Nickel & $\mathrm{N} / \mathrm{D}$ & $\mathrm{N} / \mathrm{D}$ \\
Seleni um & $1.74 \times 10^{-5}$ & $8.27 \times 10^{-7}$ \\
Silver & $\mathrm{N} / \mathrm{D}$ & $\mathrm{N} / \mathrm{D}$ \\
Thallium & $\mathrm{N} / \mathrm{D}$ & $\mathrm{N} / \mathrm{D}$ \\
Zinc & $1.96 \times 10^{-4}$ & $1.08 \times 10^{-4}$ \\
Cianium & $\mathrm{N} / \mathrm{D}$ & $\mathrm{N} / \mathrm{D}$ \\
Thorium & $\mathrm{N} / \mathrm{D}$ & $\mathrm{N} / \mathrm{D}$ \\
Radium-226 & $\mathrm{N} / \mathrm{D}$ & $\mathrm{N} / \mathrm{D}$ \\
Radium-228 & $\mathrm{N} / \mathrm{D}$ & $\mathrm{N} / \mathrm{D}$ \\
Lead-210 & $\mathrm{N} / \mathrm{D}$ & $\mathrm{N} / \mathrm{D}$ \\
\hline N/D No results available. & \\
\hline
\end{tabular}


No data were found for the trace metal content of the scrubbing media used in the regenerable processes. Since very little of the media ends up as W, solid waste, no account has been taken of its trace elements.

The total quantity of lime or limestone required depends on the amount of $\mathrm{SO}_{2}$ to be removed. The equations and default valuss used to compute the amount of scrubbing media are given in Appendix 2R. The resulting coefficients are as follows:

Lime. Quantity of 1 ime $=0.975 \mathrm{SO}_{2}$ tons.

Limestone. Quantity of limestone $=1.7625 \mathrm{SO}_{2}$.

Double Alkalf. Quantity of lime $=0.925 \mathrm{SO}_{2} \cdot$

In the above,

$\mathrm{SO}_{2}=$ quantity of $\mathrm{SO}_{2}$ captured.

The quantity of scrubbing media is multiplied by the coefficients in Table 2.6 to give the trace metals in the FGD sludge.

Trace Elements from Combustion Flue Gas. No reports were avallable which gave any data on the fate of trace elements in a plant where there is a high efficiency precipitator followed by a FGD system. Until data become avaflable it is assuned that for all elements, except mercury, the pass-through is the same as for fly ash (35\%). In fact there will be very little of each element entering the FGD system as most of it will have been removed in the fly ash. For mercury, a figure of $87 \%$ pass-through is used. This is the figure given in Reference 2 for a plant fitted with an FGD system to remove both particulates and $\mathrm{SO}_{2}$. Since such a small fraction of the mercury is removed by a precipitator, its presence before a FGD system w111 probably have very little effect on the removal of mercury by the FGD system. 
For the regenerable systems, only a small fraction of the scrubbing media appears as solid waste. The fate of the trace metals during the regeneration process is unknown at present. Most of the trace metals probably remain in the regenerated scrubbing media and a concentration will build up until an equilibrium is reached. However, there are no data avallable to say how much concentration there is. At present the module slmply assumes that $8 \%$ of the scrubbing media appears as solid waste and therefore $8 \%$ of the Incoming trace metals also come out in the solid waste. The quantities are in any case very smal1.

Total Trace Elements. The two sources of trace elements are added together. The output vector for FGD waste gives the total amount of dry trace elements.

\subsection{Description of FGD Residuals for an FGD System Only}

The composition of the stack gas from the boiler is used as an input to the FGD system. The switch determining which particular type of FGD system and its efflciency in terms of $\mathrm{SO}_{2}$ removal are given as input variables. The use of a lime or a limestone wet scrubber or a dry sorbent injection system was assumed.

Major Components. In this case all the captured particulates appear with the FGD waste. The quantity of fly ash w11 depend on the efficiency of the system and is calculated as follows:

$$
\mathrm{QFA}_{\mathrm{FA}}=\mathrm{QFAS}_{\mathrm{F}} \sigma / 100 \text {, }
$$

where

$$
\begin{aligned}
\text { QFAS } & =\text { quantity of fly ash entering FGD system. } \\
\sigma & =\text { percentage removal of particulates (given as an input variable). }
\end{aligned}
$$


This gives the dry quantity of ash which is shown in the output under element $1(\mathrm{ash})$. For wet FGD systems the total solid waste (element 25) is given as a wet quantity and includes the wet ash. Again the moisture content of the ash is assuned to be the same as for the overall FGD system. For dry sorbent infection, the total solid waste is a dry amount. There is no separate output vector to describe the fly ash.

For wet systems, the other major components are identical to those where the FGD system follows a precipitator.

Table 2.7 gives the coefficients used for the dry sorbent system. The equations and assumptions used are given in Appendix 2B. Since this system is not commercially operational, there are very few data on the varlables such as the stoichiometric ratio of $\mathrm{SO}_{2}$ to sorbent required to achieve a certain level of $\mathrm{SO}_{2}$ removal and the sorbent utilization. The coefficients should therefore be treated as tentative and should be updated as more data become available.

Minor Components. For wet systems the calculation of the trace metals from the scrubbing media is identical to that for $a$ FGD system following a precipitator. In the case of the trace metals from the flue gas, Reference 2 gives results for a plant where a FGD system is used to remove particulates and $\mathrm{SO}_{2}$. The results are given in Appendix 2A, Table 2A.17. However, in th:s case the amount of trace elements passing through the FGD system w11 depend on the removal rate for particulates. Unfortunately, as results are available for only one plant, relationships between fly" ash removal and trace metal removal cannot be established. Until more data become avallable it was decided to use the same coefficlents as for the preclpitator rather than to 
Table 2.7

Coefficients To Calculate FGD Waste and Its Ma jor Components for a Dry Sorbent Injection System

\begin{tabular}{ll}
\hline Component & Coefficient \\
\hline Total FGD solid waste & $3.075 \mathrm{SO}_{2}$ \\
Sodium bicarbonate & $0.046 \mathrm{SO}_{2}$ \\
Sodium carbonate & $0.781 \mathrm{SO}_{2}$ \\
Sodium sulfate & $1.605 \mathrm{SO}_{2}$ \\
Sodium sulfite & $0.643 \mathrm{SO}_{2}$ \\
\hline
\end{tabular}

give only one removal rate regardless of fly ash capture, which would have occuried had the results from Reference 2 been used.

The only exception to this is mercury. From Reference 2 it would appear that a FGD system removes more mercury than a precipitator and both are probably independent of the fly ash removal rate. A figure of $87 \%$ passthrough is therefore assumed.

For the dry sorbent injection system there are no trace element data available. Again the same coefficients are used as for a precipitator, which is a reasonable assumption since the ash is being collected in a baghouse precipitator. The trace elements from the sorbent should be added to those in the ash; however, at present there are no data for the trace element content of nahcolite.

\subsection{Description of Stack Gas Residuals}

A final output vector gives the composition of the stack gas. For elements 1 and 3 to 23 this is the remainder of the input which has not been captured in the bottom ash, fly ash, or FGD sludge. Element 2 (sulfur) and eilement 40 (carbon) will be zero and element 36 will give the quantity of $\mathrm{SO}_{2}$ not captured by the FGD system and element 42 the quantity of $\mathrm{CO}_{2}$ formed. 
Elements 36 to $38, \mathrm{NO}_{2}, \mathrm{CO}$, and $\mathrm{CH}_{4}$ are calculated from the coal input as botler residuals and the amounts are passed through unaltered to appear in the stack gas output.

\subsection{Computer Code}

A description of the computer code used is given in Appendix 2C. In Appendix 2D there is a copy of the code along with a sample input and output. 
REFERENCES

1. U.S. Environmental Protection Agency, Compilation of Air Pollutant Emission Factors (Third Ed.) Supplement 8, Office of Air and Waste Management, Pub. No. AP-42, Aug. 1977.

2. Radian Corporation, Coal Fired Power Plant Trace Element Study (Volume 1) PB-257 293, U.S. Environmental Protection Agency, Denver, Co, Region VIII, Sept. 1977.

3. D. H. Klein, A. W. Andren, J. A Carter, J. F. Emery, C. Feldman, W. Fulkersen, W. S. Lyon, J. C. Ogle, Y. Talmi, R. I. Van Hook, and N. Bolton, Pathways of thirty-seven trace elements through coal fired power plant, Environ. Sci. Technol. 9, 973, 1975.

4. N. F. Bolton, R. I. Van Hook, W. Fulkersen, W. S. Lyon, A. W. Andren, J. A. Carter, and J. F. Emery, Trace Element Measurements at the Cual Fired Allen Steam Plant - Progress Rep. June 1971 - January 1973, ORNL-NSF-EP-43, Oak RIdge National Laboratory, Mar. 1973.

5. W. S. Lynn, Trace Element Measurements at the Allentown Coa1-Fired Steam Plant, CRC Press, Cleveland, OH, 1977.

6. C. Cowherd, Jr., Hazardous Emission Characterization of Utility Boilers, EPA-650/2-75-066, U.S. Environmental Protection Agency, Office of Research and Development, Washington, DC, July 1975.

7. J. W. Kaakinen, R. M. Jorden, M. H. Lawasani, and R. E. West, Trace element behavior in coal-fired power plant, Environ. Sci. Tech. $\underline{9}, 862$, 1975.

8. J. Rossoff and P. P. Leo, Controlling $\mathrm{SO}_{2}$ Emissions from Coa1-Fired Steam-Electric Generators: Solld Waste Impact, EPA-600/7-78-044a and 044b, U.S. Environmental Protection Agency, Washington, DC, Mar. 1978.

9. U.S. Environmental Protection Agency, Electric Utility Steam Generating Units: Background Information for Proposed Particulate Matter Emission Standards, EPA-450/2-78-006a, Office of Air, Nolse and Radiation, Research Triangle Park, NC, July 1978.

10. Radian Corporation, Evaluation of Lime/Limestone Sludge Disposal Options, PB-232-022, U.S. Environmental Protection Agency, Research Triangle Park, NC, Nov. 1973.

11. R. L. Davison, D.F.S. Natusch, and J. R. Wallace, Trace elements in fly ash-dependence on particle size, Environ. Sci. Technol., 8, 1107, 1974.

12. D. G. Coles, R. C. Ragain1, and J. M. Ondov, The behavior of the natural radionuclides in Western coal-fired power plants, Environ. Sci. Technol., $12,442,1978$. 
13. TRW Inc., Evaluation of Dry Sorbents and Fabric Filtration for FGD, prepared for U.S. Environmental Protection Agency, EPA-600/7-79-005, Jan. 1979.

14. P.D. Moskowitz, S.C. Morris, and A.S. Albanese, The global carbon dioxide problem: Impacts of U.S. Synthetic fuel- and coal-fired electricity generating plants, J. Air Poll. Cont. Assoc., 30, 353, 1980. 
APPENDIX $2 \mathrm{~A}$

CALCULATION OF BOILER COEFFICIENTS

2A.1 Botton Ash

Utility Pulverized Boiler. Coefficlent. were calculated from Reference 2, which gives regults for two stations with pulverized bollers (station I and station II). In general, the mass balances obtalned were falrly close to unity, the major discrepancies being

Mercury Station II

Nickel Station II

Cadmu um Stations I and II

Lead Stations I and II

Thorium Station I and II

Thallium Station I and II

The results had already been normalized in the report to give mass balances of 100\%. Tables 2A.1, 2A.2, and $2 \mathrm{~A} .3$ give the results. An average figure for the percentage of an incoming trace element which remains in the bottom ash was calculated by taking the geometric mean of the figures for the two stations. The results are given in Table 2A.4. In order to produce coefficients for the module, a fraction rather than a percentage was used, and since the coefficients are for the amount going into the stack gas, the coefficlents are 1 minus the amount in the boller ash fraction.

Utility Cyclone Boiler. Coefficients were calculated from References 2 and 5. Reference 5 gave two sets of results for experiments conducted in 1972 and 1973. 
Table 2A. 1

Fraction of Elements Entering with Coal Discharged in Bottom Ash or Sluice Ash for Sampled Stations, Reference 2

\begin{tabular}{|c|c|c|c|}
\hline Element & $\begin{array}{c}\text { Station I } \\
\text { Bottom Ash } \\
(21.3 \%)\end{array}$ & $\begin{array}{c}\text { Station II } \\
\text { Sluice Ash } \\
(22.2 \%)\end{array}$ & $\begin{array}{c}\text { Station III } \\
\text { Bottom Ash } \\
(63.1 \%)\end{array}$ \\
\hline $\begin{array}{l}\text { Antimony } \\
\text { Arsenic } \\
\text { Beryllium } \\
\text { Cadmium } \\
\text { Chromium } \\
\text { Copper } \\
\text { Iron } \\
\text { Lead } \\
\text { Magnesium } \\
\text { Manganese } \\
\text { Mercury } \\
\text { Nickel } \\
\text { Selenium } \\
\text { Silver } \\
\text { Thalifum } \\
\text { Thorium } \\
\text { Uranium } \\
\text { Zinc }\end{array}$ & $\begin{array}{r}9.9 \\
5.0 \\
15.7 \\
8.9 \\
10.7 \\
12.4 \\
20.4 \\
3.1 \\
17.7 \\
13.5 \\
0.78 \\
18.3 \\
0.0 \\
9.5 \\
11.5 \\
14.3 \\
50.1 \\
4.4\end{array}$ & $\begin{array}{r}2.7 \\
0.8 \\
16.9 \\
<15.7 \\
13.9 \\
12.7 \\
27.9 \\
10.3 \\
17.2 \\
17.3 \\
2.1 \\
13.6 \\
1.4 \\
3.2 \\
12.33 \\
27.5 \\
18.0 \\
29.4\end{array}$ & $\begin{array}{l}15.9 \\
16.9 \\
58.2 \\
26.8 \\
44.2 \\
34.1 \\
61.8 \\
<7.8 \\
62.1 \\
62.5 \\
20.8 \\
22.7 \\
2.3 \\
22.0 \\
2.6 \\
72.2 \\
42.7 \\
13.3\end{array}$ \\
\hline
\end{tabular}

Table 2A. 2

Fraction of Elements Entering with Coal Discharged in Economizer Ash Plus Scrubber Slurry or Cyclone Ash or Preclpitator Ash for Sampled Stations, Reference 2

\begin{tabular}{|c|c|c|c|}
\hline E1ement & $\begin{array}{c}\text { Station I } \\
\text { Economizer Ash \& } \\
\text { Scrubber Slurry } \\
(78.5 \%)\end{array}$ & $\begin{array}{c}\text { Station II } \\
\text { Precipitator } \\
\text { Ash } \\
(77.1 \%)\end{array}$ & $\begin{array}{l}\text { Station III } \\
\text { Economizer Ash } \\
\& \text { Cyclone Ash } \\
(24.0 \%)\end{array}$ \\
\hline $\begin{array}{l}\text { Antimony } \\
\text { Arsenic } \\
\text { Berylilum } \\
\text { Cadmium } \\
\text { Chromium } \\
\text { Copper } \\
\text { Iron } \\
\text { Lead } \\
\text { Magnesium } \\
\text { Marganese } \\
\text { Mercury } \\
\text { Nickel } \\
\text { Selenium } \\
\text { Silver } \\
\text { Thalilum } \\
\text { Thorium } \\
\text { Uranium } \\
\text { Zinc }\end{array}$ & $\begin{array}{l}89.4 \\
87.6 \\
83.8 \\
84.2 \\
79.4 \\
87.0 \\
80.0 \\
94.9 \\
81.1 \\
85.9 \\
12.5 \\
77.6 \\
97.8 \\
86.1 \\
65.4 \\
85.6 \\
47.8 \\
93.0\end{array}$ & $\begin{array}{l}93.4 \\
99.1 \\
81.0 \\
80.5 \\
73.7 \\
86.5 \\
71.3 \\
82.2 \\
82.0 \\
81.5 \\
0.0 \\
68.2 \\
60.9 \\
95.5 \\
82.2 \\
72.4 \\
80.5 \\
68.0\end{array}$ & $\begin{array}{l}6.2 \\
62.6 \\
35.0 \\
32.5 \\
15.4 \\
37.2 \\
20.7 \\
27.7 \\
23.1 \\
25.2 \\
3.1 \\
14.3 \\
32.4 \\
62.2 \\
5.9 \\
26.3 \\
17.8 \\
34.2\end{array}$ \\
\hline
\end{tabular}




\begin{tabular}{|c|c|c|c|}
\hline \multicolumn{4}{|c|}{$\begin{array}{l}\text { Table } 2 \mathrm{~A} .3 \\
\text { Fraction of Elements Entering with Coal Discharged } \\
\text { in Flue Gas for Sampled Stations, Reference } 2\end{array}$} \\
\hline Element & $\begin{array}{l}\text { Station I } \\
\text { Flue Gas } \\
(0.3 \%)\end{array}$ & $\begin{array}{l}\text { Station II } \\
\text { Flue Gas } \\
(0.7 \%)\end{array}$ & $\begin{array}{l}\text { Station III } \\
\text { Flue Gas } \\
(12.9 \%)\end{array}$ \\
\hline $\begin{array}{l}\text { Ant imony } \\
\text { Arsenic } \\
\text { Berylilum } \\
\text { Cadmium } \\
\text { Chromium } \\
\text { Copper } \\
\text { Iron } \\
\text { Lead } \\
\text { Magnesium } \\
\text { Manganese } \\
\text { Mercury } \\
\text { Nickel } \\
\text { Selenium } \\
\text { Silver } \\
\text { Thallium } \\
\text { Thorium } \\
\text { Uranium } \\
\text { Zinc }\end{array}$ & $\begin{aligned} 0.61 \\
7.5 \\
0.65 \\
7.00 \\
9.9 \\
0.66 \\
0.63 \\
1.9 \\
1.2 \\
0.38 \\
86.8 \\
4.1 \\
2.2 \\
4.7 \\
23.0 \\
0.1 \\
2.0 \\
2.5\end{aligned}$ & $\begin{array}{r}3.9 \\
0.05 \\
<2.0 \\
<3.8 \\
12.4 \\
0.8 \\
0.8 \\
7.5 \\
0.8 \\
1.2 \\
97.9 \\
18.2 \\
27.7 \\
1.3 \\
5.5 \\
0.1 \\
1.5 \\
2.6\end{array}$ & $\begin{array}{l}77.9 \\
20.5 \\
6.5 \\
41.1 \\
40.3 \\
28.9 \\
17.5 \\
64.6 \\
14.8 \\
12.5 \\
96.1 \\
62.8 \\
65.4 \\
<15.9 \\
91.5 \\
1.5 \\
29.5 \\
52.7\end{array}$ \\
\hline
\end{tabular}

Table $2 A .4$

Calculation of Average Percentage of Trace Elements which Remain In the Bottom Ash In a Pulverized Utility Boller

\begin{tabular}{lccc}
\hline & $\begin{array}{c}\text { Station I } \\
\text { Bottom Ash (\%) }\end{array}$ & $\begin{array}{c}\text { Station II } \\
\text { Bottom Ash (\%) }\end{array}$ & $\begin{array}{c}\text { Geometric Mean } \\
\text { Bottom Ash }\end{array}$ \\
\hline Antimony & 9.9 & 2.7 & 5.17 \\
Arsenic & 5.0 & 0.8 & 2.0 \\
Beryilium & 15.7 & 16.9 & 16.29 \\
Cadmium & 8.9 & 15.7 & 11.82 \\
Chromium & 10.7 & 13.9 & 12.20 \\
Copper & 12.4 & 12.7 & 12.55 \\
Iron & 20.4 & 27.9 & 23.86 \\
Lead & 3.1 & 10.3 & 17.65 \\
Magnesium & 17.7 & 17.2 & 15.34 \\
Manganese & 13.5 & 2.3 & 1.28 \\
Mercury & 0.78 & 13.6 & 15.78 \\
Nicke1 & 18.3 & 1.4 & 1.18 \\
Selenium & 0.0 & 3.2 & 5.51 \\
Silver & 9.5 & 12.3 & 11.9 \\
Thallium & 11.5 & 27.5 & 19.8 \\
Thorium & 14.3 & 18.0 & 30.0 \\
Uranium & 50.1 & 29.4 & 11.37 \\
Zinc & 4.4 & & \\
\hline
\end{tabular}


Again, in most cases the mass balances were good, the exceptions being Antimony

Arsenic

Chromium

Copper (1972)

Mercury

The figures were recalculated to give overall mass balances of $100 \%$, assuming that any imbalance was evenly distributed between the three fractions. Tables $2 \mathrm{~A} .5$ and $2 \mathrm{~A} .6$ give the normalized figures.

Reference 2 gave one set of results (station III). These results gave very good mass balances, the only sertous imbalance being for mercury and thallium. The results had been normalized in the report and Tables 2A.1, 2A.2, and $2 A .3$ show the results obtained. An average figure for the percentage of an incoming trace element which remains in the bottom ash was calculated by taking the geometric mean of the 3 sets of results. Table $2 A .7$ gives the figures obtained. Again the coefficients were calculated as 1 minus the boiler fraction.

\section{A. 2 Fly Ash and Stack Gas.}

The figures giving the split between bottom, fly, and stack ash were recalculated for all 5 sets of results to reflect the average bottom ash content. Using the average bottom ash content for the boilers the figures for stack and $f l y$ ash were recalculated keeping their orfginal ratios to again give a mass balance of $100 \%$. Tables $2 \mathrm{~A} .8$ to $2 \mathrm{~A} .12$ give the results of these calculations. 
Tabie 2A. 5

Distribution of Trace Elements for a Cyclone Boller Normalized to Give a Mass Balance of $100 \%$, Reference 5 (1972)

\begin{tabular}{|c|c|c|c|}
\hline Trace Element & $\begin{array}{c}\text { Bottom Ash } \\
(\%)\end{array}$ & $\begin{array}{c}\text { Fly Ash } \\
(\%)\end{array}$ & $\begin{array}{c}\text { Stack } \\
(\%)\end{array}$ \\
\hline $\begin{array}{l}\text { Antimony } \\
\text { Arsenic } \\
\text { Beryilium } \\
\text { Cadmium } \\
\text { Chromium } \\
\text { Copper } \\
\text { Iron } \\
\text { Lead } \\
\text { Magnesium } \\
\text { Manganese } \\
\text { Mercury } \\
\text { Nicke1 } \\
\text { Selenium } \\
\text { Silyer } \\
\text { Thallium } \\
\text { Zinc } \\
\text { Uranium } \\
\text { Thorium }\end{array}$ & $\begin{array}{r}\text { N/D } \\
20.00 \\
\text { N/D } \\
\text { N/D } \\
59.22 \\
62.50 \\
70.15 \\
6.98 \\
67.63 \\
74: 87 \\
\text { N/D } \\
\text { N/D } \\
41.02 \\
\text { N/D } \\
\text { N/D } \\
3.62 \\
63.90 \\
68.88\end{array}$ & $\begin{array}{c}N / D \\
72.01 \\
N / D \\
N / D \\
39.10 \\
36.29 \\
28.91 \\
90.70 \\
29.95 \\
24.06 \\
N / D \\
N / D \\
33.34 \\
N / D \\
N / D \\
93.97 \\
35.14 \\
30.61\end{array}$ & $\begin{array}{l}\text { N/D } \\
7.99 \\
N / D \\
N / D \\
1.68 \\
1.21 \\
0.94 \\
2.32 \\
2.42 \\
1.07 \\
N / D \\
N / D \\
25.64 \\
N / D \\
N / D \\
2.41 \\
0.96 \\
0.51\end{array}$ \\
\hline
\end{tabular}

Table $2 A .6$

Distribution of Trace Elements for a Cyclone Boller Normalfzed to Give a Mass Balance of $100 \%$, Reference 5 (1973)

\begin{tabular}{|c|c|c|c|}
\hline Trace Element & $\begin{array}{l}\text { Bottom Ash } \\
(\%)\end{array}$ & $\begin{array}{c}\text { Fly Ash } \\
(\%)\end{array}$ & $\begin{array}{c}\text { Stack } \\
(\%)\end{array}$ \\
\hline $\begin{array}{l}\text { Antimony } \\
\text { Arsenic } \\
\text { Berylilum } \\
\text { Cadmium } \\
\text { Chromium } \\
\text { Copper } \\
\text { Iron } \\
\text { Lead } \\
\text { Magnesium } \\
\text { Manganese } \\
\text { Mercury } \\
\text { Nickel } \\
\text { Se1enium } \\
\text { Silver } \\
\text { Tha11ium } \\
\text { Zinc } \\
\text { Uranium } \\
\text { Thorium }\end{array}$ & $\begin{array}{c}4.38 \\
15: 30 \\
N / D \\
12.85 \\
36.83 \\
14.08 \\
51.19 \\
7.57 \\
57.14 \\
52.87 \\
1.89 \\
30.31 \\
76.68 \\
\text { N/D } \\
\text { N/D } \\
7.50 \\
35.89 \\
46.26\end{array}$ & $\begin{array}{c}78.08 \\
82.66 \\
N / D \\
84.29 \\
62.32 \\
85.34 \\
48.49 \\
89.40 \\
42.86 \\
46.71 \\
3.77 \\
69.30 \\
22.36 \\
N / D \\
N / D \\
90.83 \\
63.25 \\
53.58\end{array}$ & $\begin{array}{r}17.54 \\
2.04 \\
\text { N.D } \\
2.86 \\
0.85 \\
0.58 \\
0.32 \\
3.03 \\
0.00 \\
0.42 \\
94.34 \\
0.39 \\
0.96 \\
N / D \\
N / D \\
1.67 \\
0.86 \\
0.36\end{array}$ \\
\hline
\end{tabular}


Table 2A.7

Calculation of Average Percentage of Trace Elements which Remain in the Bottom Ash in a Cyclone Utility Boiler

\begin{tabular}{|c|c|c|c|c|}
\hline Trace Element & $\begin{array}{l}\text { Reference } 2 \\
\text { Station III } \\
\text { Bottom Ash (\%) }\end{array}$ & $\begin{array}{r}\text { Reference } 5 \\
1972 \\
\text { Bottom Ash (\%) }\end{array}$ & $\begin{array}{c}\text { Reference } 5 \\
1973 \\
\text { Bottom Ash (\%) }\end{array}$ & $\begin{array}{c}\text { Geometric } \\
\text { Mean } \\
\text { Bottom Ash (\%) }\end{array}$ \\
\hline Antimony & 15.9 & $\mathrm{~N} / \mathrm{D}$ & 4.38 & 8.345 \\
\hline Arsenic & 16.9 & 20.00 & 15.30 & 17.29 \\
\hline Beryllium & 58.2 & $\mathrm{~N} / \mathrm{D}$ & $\mathrm{N} / \mathrm{D}$ & 58.2 \\
\hline Cadmium & 26.8 & $N / D$ & 12.85 & 18.56 \\
\hline Chromium & 44.2 & 59.22 & 36.83 & 45.85 \\
\hline Copper & 34.1 & 62.50 & 14.08 & 31.08 \\
\hline Iron & 61.8 & 70.15 & 51.19 & 60.54 \\
\hline Lead & $<7.8$ & 6.98 & 7.57 & 7.44 \\
\hline Magnesium & 62.1 & 67.63 & 57.14 & 62.14 \\
\hline Manganese & 62.5 & 74.87 & 52.87 & 62.78 \\
\hline Mercury & $<0.8$ & $N / D$ & 1.89 & 1.23 \\
\hline Nickel & 22.7 & $\mathrm{~N} / \mathrm{D}$ & 30.31 & 26.23 \\
\hline Selenium & 2.3 & 41.02 & 76.68 & 19.34 \\
\hline Silver & 22.0 & $N / D$ & $\mathrm{~N} / \mathrm{D}$ & 22.0 \\
\hline Thallium & 2.61 & $\mathrm{~N} / \mathrm{D}$ & $\mathrm{N} / \mathrm{D}$ & 2.61 \\
\hline Zinc & 13.3 & 3.62 & 7.50 & 7.12 \\
\hline Uranium & 42.69 & 63.90 & 35.14 & 45.76 \\
\hline Thorium & 72.17 & 68.88 & 46.26 & 61.26 \\
\hline $\mathrm{N} / \mathrm{D}$ & a available. & & & \\
\hline
\end{tabular}

2A.2.1 Coefficients for a Boller Fitted With a Precipitator. The data from Reference 2, stations II and III, and Reference 5 are for bollers fitted with a precipitator for fily ash collection. The amount of most trace elements trapped in a precipitator will in some way depend on the precipitator efficiency. All four results came from plants using precipitators of differing efficiencles. The percentage of the total amount of each trace metal which passed through the precipitator into the stack gas was calculated. These figures could then be compared with the percentage pass-through of the fly ash, which are:

$\begin{array}{llr}\text { Reference } 2 & \text { Station II } & 0.9 \% \\ \text { Reference } 2 & \text { Station III } & 35.0 \%\end{array}$


Table 2A. 8

Distribution of Trace Elements, Pulverized Boiler, Station I, Reference 2, Using Average Boller Fraction and Recalculating Fly Ash and Stack Gas

\begin{tabular}{|c|c|c|c|}
\hline Trace Element & $\begin{array}{c}\text { Bottom Ash } \\
(\%)\end{array}$ & $\begin{array}{c}\text { Fly Ash } \\
(\%)\end{array}$ & $\begin{array}{c}\text { Stack } \\
(\%)\end{array}$ \\
\hline $\begin{array}{l}\text { Antimony } \\
\text { Arsenic } \\
\text { Berylifum } \\
\text { Cadmium } \\
\text { Chromium } \\
\text { Copper } \\
\text { Iron } \\
\text { Lead } \\
\text { Magnesium } \\
\text { Manganese } \\
\text { Mercury } \\
\text { Nickel } \\
\text { Selenium } \\
\text { Silyer } \\
\text { Thalitum } \\
\text { Zinc } \\
\text { Uranium } \\
\text { Thorium }\end{array}$ & $\begin{array}{r}5.17 \\
2.00 \\
16.29 \\
11.82 \\
12.20 \\
12.55 \\
23.86 \\
5.65 \\
17.45 \\
15.34 \\
1.28 \\
15.78 \\
1.18 \\
5.51 \\
11.93 \\
11.37 \\
30.03 \\
19.81\end{array}$ & $\begin{array}{l}94.185 \\
90.27 \\
83.07 \\
81.41 \\
78.06 \\
86.79 \\
75.55 \\
92.50 \\
81.34 \\
84.29 \\
12.43 \\
79.99 \\
96.65 \\
89.60 \\
65.15 \\
86.31 \\
67.16 \\
86.62\end{array}$ & $\begin{array}{r}0.645 \\
7.73 \\
0.64 \\
6.77 \\
9.74 \\
0.66 \\
0.59 \\
1.85 \\
1.21 \\
0.37 \\
86.29 \\
4.23 \\
2.17 \\
4.89 \\
22.92 \\
2.32 \\
2.83 \\
0.08\end{array}$ \\
\hline$N / D$ & vallable. & & \\
\hline
\end{tabular}

Table 2A. 9

Distribution of Trace Elements, Pulverized Boiler, Station II, Reference 2, Using Average Boller Fraction and Recalculating Fly Ash and Stack Gas

\begin{tabular}{lccr}
\hline & $\begin{array}{r}\text { Bottom Ash } \\
(\%)\end{array}$ & $\begin{array}{c}\text { Fly Ash } \\
(\%)\end{array}$ & $\begin{array}{c}\text { Stack } \\
(\%)\end{array}$ \\
\hline Arace Element & 5.17 & 91.03 & 3.80 \\
Artimony & 2.00 & 97.95 & 0.05 \\
Berylitum & 16.29 & 81.69 & 2.02 \\
Cadmium & 11.82 & 84.20 & 3.98 \\
Chromium & 12.20 & 75.16 & 12.64 \\
Copper & 12.55 & 86.65 & 0.80 \\
Iron & 23.86 & 75.29 & 0.85 \\
Lead & 5.65 & 86.46 & 7.89 \\
Magnesium & 17.45 & 81.74 & 0.81 \\
Manganese & 15.34 & 83.43 & 1.23 \\
Mercury & 15.28 & 0.00 & 98.72 \\
Nicke1 & 158 & 66.48 & 17.74 \\
Selenium & 1.18 & 67.93 & 30.89 \\
Silver & 5.51 & 93.22 & 1.27 \\
Thallium & 11.93 & 82.56 & 5.51 \\
Zinc & 11.37 & 85.37 & 3.26 \\
Uranium & 30.03 & 68.69 & 1.28 \\
Thorium & 19.81 & 86.54 & 0.16 \\
\hline \multicolumn{1}{c}{ N/D } & No data available. & & \\
\hline
\end{tabular}


Table 2A.10

Distribution of Trace Elements, Pulverłzed Boiler, Station III, Reference 2, Using Average Boiler Fraction and Recalculating Fly Ash and Stack Gas

\begin{tabular}{lccr}
\hline Trace Element & $\begin{array}{c}\text { Bottom Ash } \\
(\%)\end{array}$ & $\begin{array}{c}\text { Fly Ash } \\
(\%)\end{array}$ & $\begin{array}{c}\text { Stack } \\
(\%)\end{array}$ \\
\hline Antimony & 8.345 & 6.755 & 84.90 \\
Arsenic & 17.29 & 62.31 & 20.40 \\
Berylilum & 58.20 & 35.0 & 6.5 \\
Cadmium & 18.56 & 35.96 & 45.48 \\
Chromium & 45.85 & 14.97 & 39.18 \\
Copper & 31.08 & 38.79 & 30.13 \\
Iron & 60.54 & 21.38 & 18.08 \\
Lead & 7.44 & 27.78 & 64.78 \\
Magnesium & 62.14 & 23.08 & 14.78 \\
Manganese & 62.78 & 24.88 & 12.34 \\
Mercury & 1.23 & 35.09 & 60.09 \\
Nickel & 26.23 & 13.68 & 53.94 \\
Selenium & 19.34 & 26.72 & 15.88 \\
Silver & 22.00 & 62.12 & 91.46 \\
Thailium & 2.61 & 5.94 & 56.32 \\
Zinc & 7.12 & 36.56 & 37.43 \\
Uranium & 45.76 & 16.81 & 2.13 \\
Thorium & 61.26 & 36.61 & \\
\hline
\end{tabular}

N/D No data available.

Table 2A. 11

Distribution of Trace Elements, Reference 5 (1972), Using Average Boiler Fraction and Recalculating Fly Ash and Stack Gas.

\begin{tabular}{|c|c|c|c|}
\hline Trace Element & $\begin{array}{l}\text { Bottow Ash } \\
(\%)\end{array}$ & $\begin{array}{c}\text { Fly Ash } \\
(\%)\end{array}$ & $\begin{array}{c}\text { Stack } \\
(\%)\end{array}$ \\
\hline $\begin{array}{l}\text { Antimony } \\
\text { Arsenic } \\
\text { Beryliium } \\
\text { Cadmium } \\
\text { Chromium } \\
\text { Copper } \\
\text { Iron } \\
\text { Lead } \\
\text { Magnesium } \\
\text { Manganese } \\
\text { Mercury } \\
\text { Nickel } \\
\text { Selenium } \\
\text { Silver } \\
\text { Thallium } \\
\text { Zinc } \\
\text { Uranium } \\
\text { Thorium }\end{array}$ & $\begin{array}{c}N / D \\
17.29 \\
N / D \\
N / D \\
45.85 \\
31.08 \\
60.54 \\
7.44 \\
62.14 \\
62.78 \\
N / D \\
N / D \\
19.34 \\
N / D \\
N / D \\
7.12 \\
45.76 \\
61.26\end{array}$ & $\begin{array}{c}\mathrm{N} / \mathrm{D} \\
74.45 \\
\mathrm{~N} / \mathrm{D} \\
\mathrm{N} / \mathrm{D} \\
51.93 \\
66.69 \\
38.22 \\
90.25 \\
35.03 \\
35.63 \\
\mathrm{~N} / \mathrm{D} \\
\mathrm{N} / \mathrm{D} \\
45.60 \\
\mathrm{~N} / \mathrm{D} \\
\mathrm{N} / \mathrm{D} \\
90.56 \\
52.80 \\
38.1\end{array}$ & $\begin{array}{l}\text { N/D } \\
8.26 \\
\text { N/D } \\
\text { N/D } \\
2.22 \\
2.23 \\
1.24 \\
2.31 \\
2.83 \\
1.59 \\
N / D \\
N / D \\
35.06 \\
N / D \\
N / D \\
2.32 \\
1.44 \\
0.64\end{array}$ \\
\hline $\mathrm{N} / \mathrm{D}$ & ailable. & & \\
\hline
\end{tabular}


Table 2A. 12

Distribution of Trace Elements, Reference 5 (1973), Using Average Boiler Fraction and Recalculating Fly Ash and Stack Gas

\begin{tabular}{lccc}
\hline Trace Element & $\begin{array}{c}\text { Bot tom Ash } \\
(\%)\end{array}$ & $\begin{array}{c}\text { Fly Ash } \\
(\%)\end{array}$ & $\begin{array}{c}\text { Stack } \\
(\%)\end{array}$ \\
\hline Antimony & 8.345 & 74.845 & 16.81 \\
Arsenic & 17.29 & 80.72 & 1.99 \\
Beryliium & $\mathrm{N} / \mathrm{D}$ & $\mathrm{N} / \mathrm{D}$ & $\mathrm{N} / \mathrm{D}$ \\
Cadmium & 18.56 & 78.77 & 2.67 \\
Chromium & 45.85 & 53.42 & 0.73 \\
Copper & 31.08 & 68.45 & 0.47 \\
Iron & 60.54 & 39.20 & 0.26 \\
Lead & 7.44 & 89.52 & 3.04 \\
Magnesium & 62.14 & 37.86 & 0.00 \\
Manganese & 62.78 & 36.89 & 0.33 \\
Mercury & 1.23 & 3.79 & 94.98 \\
Nickel & 26.23 & 73.36 & 0.41 \\
Selenium & 19.34 & 77.3 & 3.29 \\
Silver & $\mathrm{N} / \mathrm{D}$ & $\mathrm{N} / \mathrm{D}$ & $\mathrm{N} / \mathrm{D}$ \\
Thallium & $\mathrm{N} / \mathrm{D}$ & $\mathrm{N} / \mathrm{D}$ & $\mathrm{N} / \mathrm{D}$ \\
Zinc & 7.12 & 91.20 & 1.68 \\
Uranium & 45.76 & 53.51 & 0.73 \\
Thorium & 61.26 & 38.48 & 0.26 \\
\hline
\end{tabular}

N/D No data available.

$\begin{array}{lcc}\text { Reference } 5 & 1972 & 3.5 \% \\ \text { Reference } 5 & 1973 & 0.5 \%\end{array}$

The results, given in Table $2 \mathrm{~A} .13$, were used in an attempt to derive a function for the percent pass-through $\left(P_{X}\right)$ of each trace element ( $x$ ) based on the percentage age pass-through $\left(P_{\mathrm{TP}}\right)$ of the fly ash, where

$$
P_{T P}=100-(\text { efficiency of precipitator). }
$$

Other research was also used to assist in deriving these functions. Two steps were used in arriving at these functions:

a) determination of functional relationship (i.e., linear, exponential, etc.),

b) calculation of a coefficient for that relationship. 
Determination of Functional Relationships. Past studies 2,5 indicate that some trace metals are enriched after the flue gas passes through a prectpitator and some are not, i.e., those that are enriched are in a higher proportion to the total mass output of the ash than they are to the total mass input to the precipitator.

The elements that are not enriched were assumed to be a linear function of $\mathrm{P}_{\mathrm{TP}}$ with a coefficient of 1 . Table $2 \mathrm{~A} .14$ shows the elements that are and are not enriched.

Trace elements that are enriched may be a linear or nonlinear function of $\mathrm{P}_{\mathrm{TP}}$. For these elements, the percent pass-through at the four power plants In Table 2A.13 were examined. For each element, the proportion

$$
P_{x}\left(p_{1}\right) / P_{x}\left(p_{j}\right)
$$

was calculated, where $P_{x}\left(P_{1}\right)=$ percentage pass-through of trace element $x$ for a power plant with precipitator efficiency $p_{1}, i=1,2,3,4$ and $p_{1}=.5, .9,3.5$, 35. These proportions for the enriched trace elements are shown in Table 2A. 15.

These results were then compared to proportions which would exist if $P_{x}$ were various functions of $P_{T P}$, under the assumption that if

$$
P_{x}\left(P_{1}\right)=C \cdot f\left(P_{T P}\left(P_{1}\right)\right)
$$

where $C$ is some coefficient, then

$$
\frac{P_{X}\left(p_{1}\right)}{P_{X}\left(p_{j}\right)}=\frac{c \cdot f\left(P_{T P}\left(p_{1}\right)\right)}{C \cdot f\left(P_{T P}\left(p_{j}\right)\right)}=\frac{f\left(P_{T P}\left(p_{1}\right)\right)}{f\left(P_{T P}\left(p_{j}\right)\right)} .
$$

The proportions for the various functions examined are in Table 2A.16.

When a trace element falled to resemble any theoretical function, possible spurious values were eliminated from Table 2A.13 and another comparison was made using only the remaining values. 


\begin{tabular}{|c|c|c|c|c|}
\hline \multicolumn{5}{|c|}{$\begin{array}{l}\text { Table 2A.13 } \\
\text { Percentage Pass-Through of Trace Elements } \\
\text { for Preclpitators of Varying Efflciency }\end{array}$} \\
\hline Trace Element & $\begin{array}{c}\text { Reference } 5 \\
(1972) \\
{[0.5 \%] 1} \\
\end{array}$ & $\begin{array}{c}\text { Reference } 2 \\
\text { Station II } \\
{[0.9 \%]^{1}} \\
\end{array}$ & $\begin{array}{c}\text { Reference } 5 \\
(1973) \\
{[3.5 \%] 1} \\
\end{array}$ & $\begin{array}{l}\text { Reference } 2 \\
\text { Station III } \\
{[35 \%]^{1}}\end{array}$ \\
\hline $\begin{array}{l}\text { Antimony } \\
\text { Arsenlc } \\
\text { Beryllium } \\
\text { Cadmium } \\
\text { Chronium } \\
\text { Copper } \\
\text { Iron } \\
\text { Lead } \\
\text { Magnesium } \\
\text { Manganese } \\
\text { Mercury } \\
\text { Nickel } \\
\text { Selentum } \\
\text { S1lver } \\
\text { Thallium } \\
\text { Z1nc } \\
\text { Uranium } \\
\text { Thorium } \\
\text { Radium }\end{array}$ & $\begin{array}{c}18.34 \\
2.41 \\
N / D \\
3.28 \\
1.35 \\
0.68 \\
0.66 \\
3.28 \\
0.00 \\
0.88 \\
96.16 \\
0.55 \\
4.08 \\
N / D \\
N / D \\
1.81 \\
1.34 \\
0.67 \\
N / D \\
\end{array}$ & $\begin{array}{c}4.01 \\
0.05 \\
2.41 \\
4.51 \\
14.40 \\
0.92 \\
1.12 \\
8.36 \\
0.98 \\
1.45 \\
100.00 \\
21.1 \\
31.26 \\
1.34 \\
6.25 \\
3.67 \\
1.83 \\
0.18 \\
\text { N/D }\end{array}$ & $\begin{array}{l}N / D \\
9.99 \\
N / D \\
N / D \\
4.1 \\
3.24 \\
3.14 \\
2.50 \\
7.47 \\
4.27 \\
N / D \\
N / D \\
43.5 \\
N / D \\
N / D \\
2.49 \\
2.65 \\
1.65 \\
N / D\end{array}$ & $\begin{array}{l}92.63 \\
24.66 \\
15.66 \\
55.84 \\
72.35 \\
43.72 \\
45.82 \\
70.00 \\
39.04 \\
33.17 \\
96.87 \\
81.45 \\
66.87 \\
20.36 \\
93.9 \\
60.65 \\
69.0 \\
5.5 \\
\text { N/D }\end{array}$ \\
\hline $\begin{array}{l}N / D \quad \text { No } \\
\mathrm{l}_{\text {Percenta }}\end{array}$ & $\begin{array}{l}\text { ava1lable. } \\
\text { ss-through }\end{array}$ & fly ash. & & \\
\hline
\end{tabular}

Table 2A.14

Enrichment of Trace Elements upon Passing through Preclpitator

\begin{tabular}{lll}
\hline Enriched & Not Enriched \\
\hline Antimony & Beryllium \\
Arsenic & Iron \\
Cadmium & Magnesium \\
Chromium & Manganese \\
Copper & \\
Lead & \\
Mercury & \\
Nickel & \\
Selenium & \\
Silver & \\
Thallium & \\
Zinc & \\
\hline
\end{tabular}


Table 2A.15

Ratios of Pass-Through of Trace Elements at Four Power Plants

\begin{tabular}{|c|c|c|c|c|c|c|}
\hline Rat1o & $\frac{P_{x}(.5)}{P_{x}(.9)}$ & $\frac{P_{x}(.5)}{P_{x}(3.5)}$ & $\frac{P_{x}(.5)}{P_{x}(35 .)}$ & $\frac{P_{x}(.9)}{P_{x}(3.5)}$ & $\frac{P_{x}(.9)}{P_{x}(35 .)}$ & $\frac{P_{x}(3.5)}{P_{x}(35)}$ \\
\hline Ratio & (1) & (2) & (3) & (4) & (5) & $(6)$ \\
\hline $\begin{array}{l}\text { Antimony } \\
\text { Arsentc } \\
\text { Cadmium } \\
\text { Chromf um } \\
\text { Copper } \\
\text { Lead } \\
\text { Mercury } \\
\text { Nickel } \\
\text { Selentum } \\
\text { Silver } \\
\text { Thallium } \\
\text { Zinc } \\
\text { Urantum } \\
\text { Thorium } \\
\text { Radium }\end{array}$ & $\begin{array}{l}4.57 \\
48.2 \\
0.727 \\
0.094 \\
0.745 \\
0.392 \\
0.962 \\
0.026 \\
0.131 \\
\text { N/D } \\
\text { N/D } \\
0.493 \\
0.732 \\
3.72 \\
\text { N/D }\end{array}$ & $\begin{array}{c}N / D \\
0.241 \\
N / D \\
0.329 \\
0.211 \\
1.132 \\
N / D \\
N / D \\
0.094 \\
N / D \\
N / D \\
0.727 \\
0.506 \\
0.406 \\
N / D\end{array}$ & $\begin{array}{c}0.198 \\
0.098 \\
0.059 \\
0.019 \\
0.016 \\
0.047 \\
0.993 \\
0.007 \\
0.061 \\
N / D \\
N / D \\
0.030 \\
0.019 \\
0.122 \\
N / D\end{array}$ & $\begin{array}{c}N / D \\
0.005 \\
N / D \\
3.512 \\
0.284 \\
3.344 \\
N / D \\
N / D \\
0.719 \\
N / D \\
N / D \\
0.180 \\
0.691 \\
0.109 \\
N / D\end{array}$ & $\begin{array}{c}0.043 \\
0.002 \\
0.081 \\
0.199 \\
0.021 \\
0.119 \\
1.032 \\
0.259 \\
0.467 \\
0.066 \\
0.067 \\
0.061 \\
0.027 \\
0.033 \\
N / D\end{array}$ & $\begin{array}{c}N / D \\
0.405 \\
N / D \\
0.057 \\
0.074 \\
0.036 \\
N / D \\
N / D \\
0.651 \\
N / D \\
N / D \\
0.041 \\
0.038 \\
0.300 \\
N / D\end{array}$ \\
\hline
\end{tabular}

N/D - No data avallable.

Table 2A.16

Theoretical Proportions of Trace Metal Pass-Through for Given Functions of Fly Ash Pass-Through

\begin{tabular}{rlllllll}
\hline Function & $\begin{array}{l}f(.5) / \\
f(.9)\end{array}$ & $\begin{array}{l}f(.5) / \\
f(3.5)\end{array}$ & $\begin{array}{l}f(.5) / \\
f(35 .)\end{array}$ & $\begin{array}{l}f(.9) / \\
f(3.5)\end{array}$ & $\begin{array}{l}f(.9) / \\
f(35)\end{array}$ & $\begin{array}{l}f(3.5) / \\
f(35)\end{array}$ \\
\hline$f\left(P_{T P}\right)$ & $=1$ & 1.0 & 1.0 & 1.0 & 1.0 & 1.0 & 1.0 \\
& $=P_{T P}$ & 0.556 & 0.143 & 0.014 & 0.257 & 0.026 & 0.100 \\
& $=P_{T P}$ & 0.309 & 0.020 & 0.0002 & 0.066 & 0.001 & 0.010 \\
& $=\sqrt{P_{T P}}$ & 0.745 & 0.378 & 0.120 & 0.507 & 0.160 & 0.316 \\
& $\left.=\log _{\mathrm{TP}}+1\right)$ & 0.632 & 0.270 & 0.114 & 0.427 & 0.181 & 0.423 \\
& $=\sqrt{P_{T P}+1}$ & 0.889 & 0.577 & 0.207 & 0.650 & 0.233 & 0.359 \\
& $=\left(\mathrm{P}_{\mathrm{TP}}+1\right)^{2}$ & 0.623 & 0.111 & 0.002 & 0.178 & 0.003 & 0.016 \\
\hline
\end{tabular}

If a trace element still falled to conform to a specific function, it was compared to elements with "known" functlonal relationships for olmilar characteristics (e.g., preferential adhecence to various-sized particles in 
the flue gas 11 ) and given the same function as those elements that were similar.

The determined function for each of the enriched elements is as follows:

Arsentc: Assuming that $\mathrm{P}_{\mathrm{As}}(.9)=0.5 \mathrm{is}$ an analytic error, the proportions for As are similar to those for $f\left(P_{T P}\right)=\log \left(P_{T P}+1\right)$, 1.e., started $\log$ of $\mathrm{P}_{\mathrm{TP}}$.

Antimony, Cadmium, Selentum. These elements falled to conform to any function, but had similar particle-size adherence preferences to As (Reference 11). They were therefore assumed to be functions of the started $\log$ of PTP.

Chromium, Nickel: These metals did not favorably compare to any one function of $P_{T P}$. However, they seemed concentrated evenly over different sized particles.11 They were therefore assumed to be related to $P_{T P}$ by a linear function.

Copper: Except for the proportion $\mathrm{P}_{\mathrm{Cu}}(.5) / \mathrm{P}_{\mathrm{Cu}}(.9)$, a linear trend is indicated.

Lead: Assuning that the value of $\mathrm{P}_{\mathrm{Pb}}(3.5)$ is an error, $\mathrm{Pb}$ seems more 1ike a function of the started $10 \mathrm{~g}$ of $\mathrm{P}_{\mathrm{TP}}$, although the pioportions are highly var Lable.

Mercury: Proportions Indicate almost 100\% pass-through.

S1lver: The proportion of Ag looks linear, and the actual values of the two silver measurements resemble those for Mn and Be. Although there are not many data, a Iinear relationship is assumed between $\mathrm{P}_{\mathrm{Ag}}$ and $\mathrm{P}_{\mathrm{TP}}$. 
ZInc: The value of $P_{\mathrm{Zn}_{\mathrm{n}}}(3.5)$ appears to be too small. All proportions not involving $P_{T P}=3.5$ indicate a linear trend.

Thallium: There are only two data points for thallium. Their ratio falls between the linear and square root ratio. Since the ratio in Table 2A.15 looks similar to silver and zinc (which are linear in $P_{\text {TP }}$ ) the linear relation was chosen.

Radiun: No data was available for radium. A linear relationship with coefficient 1.5 was chosen based on information in Reference 12.

Thorium: Thorium has a very low value for $\mathrm{P}_{\mathrm{TP}}=.9$. All ratios not involving this value indicate that thorium has a square root relation with $\mathbf{P}_{\mathbf{T P}}$.

Uranium: The uranium ratios are simflar to efther the linear or square root ratios. However, since the data are very similar to that of zinc, the Iinear relationship was chosen.

Calculation of Coefficlents. After having decided upon the functional relations to be used, a coefficlent was then calculated by doing a least squares regression on the values for each trace metal, using values which were not considered spurious, and forcing the line to go through the origin.

Table $2 A .17$ gives the coefficient, functional relationship, and coments for all trace elements which become enriched upon passing through the precipitator.

2A.2.2 Coefficlents for a Boiler Fitted with a FGD System. Reference 2, station I, gives resulta for a boller followed by a scrubber for fly ash 
Table 2A.17

Relation of Particulate Pass-Through to Enriched Trace Element PasgThrough for Enriched Trace Elements.

\begin{tabular}{|c|c|c|c|c|}
\hline Trace Element & Coefficient & $f\left(P_{T P}\right)$ & Comments & \\
\hline Antimony & 25.84 & started $\log$ & used values at $P_{T P}=.9,35$ & \\
\hline Arsentc & 6.84 & started $\log$ & used values at $P_{T P}=.5,3.5,35$ & \\
\hline Cadmium & 15.23 & started $\log$ & used all avallable data points & \\
\hline Chromium & 2.05 & linear & used values at $P_{T P}=.5,3.5,35$ & \\
\hline Copper & 1.25 & Iinear & used all values & \\
\hline Lead & 19.19 & started $\log$ & used values at $\mathrm{P}_{\mathrm{TP}}=.5, .9,35$ & \\
\hline Mercury & .975 & constant & assume constant pass-through & $97.5 \%$ \\
\hline Nickel & 2.33 & IInear & used values at $P_{T P}=.5,35$ & \\
\hline Selenfum & 20.84 & started $\log$ & used all values & \\
\hline Silver & .58 & 11near & used all avallable data & \\
\hline Thallium & 2.69 & linear & used all avallable data & \\
\hline Zinc & 1.73 & IInear & used values at $P_{T P}=.5, .9,35$ & \\
\hline Uranfum & 1.97 & IInear & used all values & \\
\hline Thorfum & 0.86 & square root & used values at $P_{\mathrm{TP}} 0.5,3.5,35$ & \\
\hline Radium-226 & 1.5 & IInear & assumed from Reference 12 & \\
\hline Rad1 um-228 & 1.5 & linear & assumed from Reference 12 & \\
\hline Lead-210 & 19.19 & started 108 & assumed same as nonradioactive & lead \\
\hline
\end{tabular}

collection. The figures taken from the results from plants fitted wth precipltators were reworked to give the percentage of the total trace metal going into the FGD scrubber which passes through into the stack gas. This can be compared to the overall pass-through of the fly ash. Table $2 A .18$ gives the results. Unfortunately, since this was the only set of results, coefficlents similar to those for passage through a precipitator could not be calculated. 


\section{Table 2A.18}

Percentage Pass-Through of Trace Elements as Compared to the Pass-Through of Fly Ash for a Scrubber (Figures Taken from Reference 2, Station I

Trace Element Reference 2, Station I Antimony $(0.4 \%)^{1}$

Arsenic 0.68

Bery11ium 7.89

Cadmium

0.76

Chromium

7.68

Copper

11.10

Iron

0.75

Lead

0.77

Magnesium

1.96

Manganese

1.46

Mercury

0.44

Nickel

87.4

Selentum

5.02

Silver

2.20

Thallium

5.17

Zinc

26.02

Thorium

2.62

4.04

Uranium

0.09

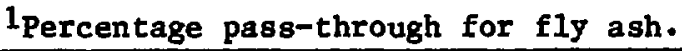


2B.1 Equations Used To Calculate Quantity of FGD Sludge and Its Major Components for Wet Scrubbing Systems.

The equations were developed using a mass balance approach and the assumptions given in Reference 8. The default values are also taken from Reference 8 . The equations are given below and the default values substituted into the equations are given in Table 2B.1. Table 2B.2 gives the chemical formulae and molecular wefghts used.

2B.1.1 Quantity of $\mathrm{SO}_{2}$ Captured (tons)

$$
\mathrm{SO}_{2}=\mathrm{SO}_{2} \mathrm{FG} \cdot \Omega / 100,
$$

where

$$
\begin{aligned}
\mathrm{SO}_{2} \mathrm{FG} & =\text { quantity of } \mathrm{SO}_{2} \text { entering } \mathrm{FGD} \text { system, } \\
\Omega & =\text { percentage of removal of } \mathrm{SO}_{2}, \text { given as an input variable. }
\end{aligned}
$$

\section{B.1.2 Lime Scrubber}

Quantity of Lime Required ( $Q_{11 m a}$ ) (tons)

$$
\begin{aligned}
& Q_{\text {1ime }}=\mathrm{SO}_{2}(1-U)+\mathrm{SO}_{2} \cdot \frac{\text { MW lime }}{\text { MW SO} 2}, \\
& Q_{\text {1Ime }}=0.975 \mathrm{SO}_{2} .
\end{aligned}
$$

where

$$
\begin{aligned}
\mathrm{SO}_{2} & =\text { quantity of } \mathrm{SO}_{2} \text { captured (tons) } \\
\mathrm{U} & =\text { absorbent utilization (fraction) molar basis, } \\
\mathrm{MW} & =\text { molecular welght }
\end{aligned}
$$


Table 2B. 1

Default Values for Calculation of FGD Solid Waste

\begin{tabular}{|c|c|c|c|c|c|}
\hline Variable & Lime & Limestone & $\begin{array}{l}\text { Double- } \\
\text { Alkali }\end{array}$ & $\begin{array}{l}\text { Magnesium } \\
\text { Oxide }\end{array}$ & $\begin{array}{l}\text { Wellman- } \\
\text { Lord }\end{array}$ \\
\hline $\begin{array}{l}\text { Absorbent utilization } \\
\text { U } \\
\text { Sulfite: sulfate ratio } \\
X \\
Y \\
\text { Soda-ash makeup } \\
\text { SA } \\
\text { Moisture content (M) } \\
\text { Absorbent makeup } \\
\text { AB } \\
\text { Separation loss } \\
\text { SL }\end{array}$ & $\begin{array}{l}90 \times(36) \\
0.9 \\
3.1(26) \\
3 \\
1 \\
\text { N/A } \\
\text { N/A } \\
50 \\
\text { N/A } \\
\text { N/A } \\
\text { N/A } \\
\text { N/A }\end{array}$ & $\begin{array}{l}80 x(36) \\
0.8 \\
3.1(26) \\
3 \\
1 \\
\text { N/A } \\
\text { N/A } \\
50 \\
\text { N/A } \\
\text { N/A } \\
\text { N/A } \\
\text { N/A }\end{array}$ & $\begin{array}{l}95 \%(36) \\
0.95 \\
3.1(26) \\
3 \\
1 \\
3 \%(36) \\
0.03 \\
50 \\
\text { N/A } \\
\text { N/A } \\
\text { N/A } \\
\text { N/A }\end{array}$ & $\begin{array}{l}\text { N/A } \\
\text { N/A } \\
\text { N/A } \\
\text { N/A } \\
\text { N/A } \\
\text { N/A } \\
N / A \\
35 \\
3 \approx(36) \\
0.03 \\
5 \approx(36) \\
0.05\end{array}$ & $\begin{array}{l}\text { N/A } \\
\text { N/A } \\
\text { N/A } \\
\text { N/A } \\
\text { N/A } \\
\text { N/A } \\
\text { N/A } \\
35 \\
3 \approx(36) \\
0.03 \\
5 \approx(36) \\
0.05\end{array}$ \\
\hline
\end{tabular}

N/A Not applicable.

Figures in parenthesis refer to the appropriate page number In Reference 8.

Table 2B. 2

Molecuar Welghts of Compounds Used in FGD Systems

\begin{tabular}{llc}
\hline \multicolumn{1}{c}{ Compound } & Chemical Formulae & Molecular Weight \\
\hline Sulfur dioxide & $\mathrm{SO}_{2}$ & 64 \\
Lime & $\mathrm{CaO}$ & 56 \\
Limestone & $\mathrm{CaCO}_{3}$ & 100 \\
Calcium sulfite & $\mathrm{CaSO}_{3} \cdot 1 / 2 \mathrm{H}_{2} \mathrm{O}$ & 129 \\
Calcium sulfate (gypsum) & $\mathrm{CaSO}_{4} \cdot 2_{2} \mathrm{H}_{2} \mathrm{O}^{\circ}$ & 172 \\
Sodium carbonate (soda-ash) & $\mathrm{Na}_{2} \mathrm{CO}_{3}$ & 106 \\
Magnesium oxide & $\mathrm{MgO}_{3}$ & 40 \\
Magnesium sulfite & $\mathrm{MgSO}_{3}$ & 104 \\
Sodium sulfite & $\mathrm{Na}_{2} \mathrm{SO}_{3}$ & 126 \\
Sodium bisulfite & $\mathrm{NaHSO}_{3}$ & 104 \\
Sodium bicarbonate & $\mathrm{NaCO}_{3}$ & 84 \\
Sodium carbonate & $\mathrm{Na}_{2} \mathrm{CO}_{3}$ & 106 \\
Sodium sulfate & $\mathrm{Na}_{2} \mathrm{SO}_{4}$ & 142 \\
\hline
\end{tabular}

Sludge Solld Waste. The sludge solids consist of: (1) unreacter. lime in the form of limestone, (2) calcium sulfite [x parts], and (3) calcium sulfate [y parts]. 
Unreacted I.imestone ( $Q_{u r i \text { limestone }}$ (tons)

$Q_{u r l i m e s t o n e}=Q_{\text {lime }}(1-U) \cdot \frac{\text { MW limestone }}{\text { MN lime }}$.

Qurlimestone $=0.174 \mathrm{SO}_{2}$.

Calcium Sulfite ( $Q_{\text {calcium sulfite }}$ (tons)

$Q_{\text {calcium sulfite }}=Q_{\text {lime }}-\left(Q_{\text {lime }} \cdot(1-U) \cdot \frac{x}{(x+y)} \cdot \frac{\text { MW calcium sulfite }}{\text { MW lime }}\right.$

Qcalcium sulfite $=1.516 \mathrm{SO}_{2} \cdot$

Calcium Sulfate (Qcalcium sulfate $)$ (tons)

$Q_{\text {calcium sulfate }}=Q_{1 \text { Ime }}-\left(Q_{\text {lime }} \cdot(1-U) \cdot \frac{y}{(y+x)} \cdot \frac{M W \text { calclum sulfate }}{\text { MW IIme }}\right.$

$Q_{\text {calcium sulfate }}=0.674 \mathrm{SO}_{2}$.

Total Sludge Solid Waste ( $Q_{T S W}$ ) (tons)

$Q_{\text {TSW }}(\mathrm{dry})=Q_{\text {urlimestone }}+Q_{\text {calcium sulfite }}+Q_{\text {calcium sulfate }}$

$\mathrm{Q}_{\mathrm{TSW}}(\mathrm{dry})=2.364 \mathrm{SO}_{2}$ tons.

$Q_{\mathrm{TSW}}($ wet $)=Q_{\mathrm{TSW}}(\mathrm{dry}) \cdot \frac{100}{(100-\mathrm{m})}$,

where

$m=$ molsture content of FGD sludge,

$\mathrm{Q}_{\mathrm{TSW}}$ (wet) $=4.728 \mathrm{SO}_{2}$. 


\section{B.1.3 Limestone Scrubber}

Quantity of Limestone Required $\left(Q_{1 \text { imestone }}\right)$ (tons)

$$
\begin{aligned}
& Q_{\text {1imestone }}=\mathrm{SO}_{2} \cdot(1-\mathrm{U})+\mathrm{sO}_{2} \cdot \frac{\mathrm{MW} \text { limestone }}{\mathrm{MW} \mathrm{s0} 2}, \\
& \mathrm{Q}_{\text {1imestone }}=1.7625 \mathrm{SO}_{2} \cdot
\end{aligned}
$$

where

$$
\begin{aligned}
\mathrm{SO}_{2} & =\text { quantity of } \mathrm{SO}_{2} \text { captured, } \\
\mathrm{U} & =\text { absorbent utilization (fraction) molar basis. }
\end{aligned}
$$

Sludge Solid Waste. The sludge solids consist of: (1) unreacted

limestone, (2) calcium sulfite [x parts], and (3) calcium sulfate [y parts].

Unreacted Limestone ( $\left.Q_{\text {urlimestone }}\right)$ (tons)

$$
\begin{aligned}
& Q_{u r l i m e s t o n e}=Q_{1 \text { imestone }} \cdot(1-\mathrm{U}), \\
& Q_{\mathrm{urlimestone}}=0.3525 \mathrm{SO}_{2} .
\end{aligned}
$$

Calcium Sulfite (Qcalcium sulfite) (tons)

$$
Q_{\text {calcium sulfite }}=\left(Q_{\text {limestone }}-Q_{u r l i m e s t o n e}\right) \cdot \frac{x}{(x+y)} \cdot \frac{M W \text { calcium sulfite }}{\text { MW limestone }} \text {, }
$$$$
Q_{\text {calcium sulfite }}=1.365 \mathrm{sO}_{2}
$$

\section{Calcium Sulfate ( $\left.Q_{\text {calclum sulfate }}\right)$ (tons)}

$$
\begin{gathered}
Q_{\text {calcium sulfate }}=\left(Q_{1 \text { imestone }}-Q_{\text {urlimestone }}\right) \cdot \frac{y}{(x+y)} \cdot \frac{M W \text { calcium sulfate }}{\text { MN 1imestone }}, \\
Q_{\text {calcium sulfate }}=0.631 \mathrm{sO}_{2} \cdot
\end{gathered}
$$




\section{Total Sludge Solid Waste (QTSW)(tons)}

$$
\begin{aligned}
& Q_{\mathrm{TSW}}(\mathrm{dry})=Q_{u r l i m e s t o n e}+Q_{\text {calcium sulfite }}+Q_{\text {calcium sulfate }} \\
& Q_{\mathrm{TSW}}(\mathrm{dry})=2.3485 \mathrm{SO}_{2}, \\
& Q_{\mathrm{TSW}}(\text { wet })=Q_{\mathrm{TSW}}(\mathrm{dry}) \cdot \frac{100}{(100-\mathrm{m})}, \\
& Q_{\mathrm{TSW}}(\text { wet })=4.697 \mathrm{SO}_{2} .
\end{aligned}
$$

where

$$
m=\text { moisture content of solid waste ( }) \text {, }
$$

2B.1.4 Double Alkali wet Scrubbing. The equations are 1dentical to the lime scrubber, but there is an additional amount of solid waste due to sodaash makeup to the absorbent. The absorbent utilization also differs and so the jefficients are as follows:

$$
\begin{array}{ll}
Q_{\text {Iime }} & =0.925 \mathrm{sO}_{2}, \\
Q_{\text {urlimestone }} & =0.0829 \mathrm{sO}_{2}, \\
Q_{\text {calcfum sulfite }} & =1.518 \mathrm{sO}_{2}, \\
Q_{\text {calcium sulfate }} & =0.675 \mathrm{sO}_{2} . \\
\text { Soda Ash Makeup } & \left(Q_{\text {soda_ash }}\right. \text { (tons) }
\end{array}
$$$$
\mathrm{Q}_{\text {soda-ash }}=\mathrm{SO}_{2} \cdot \mathrm{SA} \cdot \frac{\mathrm{MW} \mathrm{soda-ash}}{\mathrm{MW} \mathrm{SO} \mathrm{SO}_{2}},
$$

where

$$
\begin{aligned}
& \mathrm{SA}=\text { Soda-ash makeup (fraction) molar basis, } \\
& \mathrm{Q}_{\text {soda-ash }}=0.05 \mathrm{SO}_{2} \text { tons. }
\end{aligned}
$$


Total Sludge: $\therefore$ d Waste (QTSW) (cons)

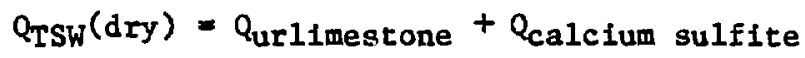

$$
\begin{aligned}
& +Q_{\text {calcium sulfate }}+Q_{\text {soda-ash }} \text {, } \\
& Q_{T S W}(d r y)=2.3259 \mathrm{SO}_{2} \text {, } \\
& Q_{\mathrm{TSW}}(\text { wat })=Q_{\mathrm{TSW}}(\mathrm{dry}) \cdot \frac{100}{(100-\mathrm{m})}, \\
& Q_{\text {TSW }}(\text { wet })=4.6518 \mathrm{sO}_{2} \text {. }
\end{aligned}
$$

2B.1.5 Magnesium 0xide. Solid waste comes from absorbent makeup (process solid waste) and from the loss in separation (regeneration solid waste).

Process Solid Waste ( $\left.Q_{\text {magnesium_oxide }}\right)$ (tons)

$$
\begin{aligned}
& \text { Qmagnesium oxide }=\mathrm{SO}_{2} \cdot \mathrm{AB} \cdot \frac{\mathrm{MW} \text { magnesium oxide }}{\mathrm{MW} \mathrm{SO} 2} \text { tons, } \\
& \mathrm{Q}_{\text {magnesium oxide }}=0.01875 \mathrm{SO}_{2} .
\end{aligned}
$$

where

$$
\begin{aligned}
& \mathrm{SO}_{2}=\text { quantity of } \mathrm{SC}: \text { iptured (tons), } \\
& \mathrm{AB}=\text { absorbent makeup (fraction) molar basis. } \\
& \text { Regeneration Solid Waste }\left(\mathrm{Q}_{\text {magnegium sulfite }}\right. \text { (tons) } \\
& \mathrm{Q}_{\text {magnesium sulfite }}=\mathrm{SO}_{2} \cdot \mathrm{SL} \cdot \frac{\mathrm{MN} \text { magnesium sulfite, }}{\mathrm{MN}_{2}} \\
& \mathrm{Q}_{\text {magnesium sulfite }}=0.08125 \mathrm{SO}_{2} .
\end{aligned}
$$

where

SL = separation loss. 


\title{
Total Sludge Solid Waste (QTSW) (tons)
}

$$
\begin{aligned}
& Q_{\text {TSW }}(d r y)=Q_{\text {magnesium oxide }}+Q_{\text {magnesium sulfite }} \\
& Q_{\text {TSW }}(d r y)=0.01 \mathrm{SO}_{2}, \\
& Q_{\text {TSW }}(\text { wet })=Q_{\text {TSW }}(\text { wet }) \cdot \frac{100}{(100-\mathrm{m})}, \\
& Q_{\mathrm{TSW}}(\text { Het })=0.1539 \mathrm{SO}_{2} .
\end{aligned}
$$

where

$m$ m moisture content of solid waste (\%).

2B.1.6 Wellman-Lord. The equations are the same as for magnesium oxide except that sodium sulfite $\left(\mathrm{Na}_{2} \mathrm{SO}_{3}\right)$ is used as the absorbent and sodium bisulfite $\left(\mathrm{NaHSO}_{3}\right)$ is produced.

\author{
Process Solid Waste (Qsodium sulfice) (tons) \\ $Q_{\text {sodium sulfite }}=\mathrm{SO}_{2} \cdot \mathrm{AB} \cdot \frac{\mathrm{MW} \text { sodium sulfite, }}{\mathrm{MW} \mathrm{S0_{2 }}}$ \\ $Q_{\text {sodium sulfite }}=0.059 \mathrm{sO}_{2}$. \\ Regeneration Solid Waste (Qsodium bisulfite) (tons) \\ $\mathrm{Q}_{\text {sodium bisulfite }}=\mathrm{SO}_{2}$. SL . MW sodium bisulfite, \\ $\mathrm{MW} \mathrm{SO}_{2}$ \\ $=0.08125 \mathrm{SO}_{2}$

\section{Total Sludge Solid Waste (QTSH) (tons)} \\ $Q_{T S W}(d r y)=Q_{\text {sodium sulfite }}+Q_{\text {sodium bisulfite }}$ \\ $Q_{\text {TSW }}(d r y)=0.14025 \mathrm{SO}_{2}$,
}




$$
\begin{aligned}
& Q_{\mathrm{TSW}}(\text { wet })=Q_{\mathrm{TSW}}(\mathrm{dry}) \cdot \frac{100}{(100-\mathrm{m})}, \\
& Q_{\mathrm{TSW}}(\text { wet })=0.2158 \mathrm{SO}_{2} \cdot
\end{aligned}
$$

where

$$
m=\text { molsture content of solid waste }(x) \text {, }
$$

2B. 2 Equations Used To Calculate Quantity of FGD Sludge and Its Major Components for Dry Sorbent Injection

All assumptions and equations are from Reference 13. Table 2B.2 sets out the chemical formulae and molecular. weights used. The desulfurization occurs via four reactions.

$2 \mathrm{NaHCO}_{3}+\mathrm{SO}_{2} \rightleftharpoons \mathrm{Na}_{2} \mathrm{SO}_{3}+\mathrm{CO}_{2}+\mathrm{H}_{2} \mathrm{O}+\mathrm{O}_{2}$

$2 \mathrm{NaHCO}_{3} \rightleftharpoons \mathrm{Na}_{2} \mathrm{CO}_{3}+\mathrm{H}_{2} \mathrm{O}+\mathrm{CO}_{2}$

$$
\begin{aligned}
& \mathrm{Na}_{2} \mathrm{CO}_{3}+\mathrm{SO}_{2} \longrightarrow \mathrm{Na}_{2} \mathrm{SO}_{3}+\mathrm{CO}_{2} \\
& \mathrm{Na}_{2} \mathrm{SO}_{3}+1 / 2 \mathrm{O}_{2} \longrightarrow \mathrm{Na}_{2} \mathrm{SO}_{4}
\end{aligned}
$$

2B.2.1 Quantity of Sodium Bicarbonate (Nahcolite) Required

From the equations, 2 moles of $\mathrm{NaHCO}_{3}$ are required to react with one mole of $\mathrm{SO}_{2}$

$$
\begin{aligned}
& Q_{\text {nahcollte }}=\mathrm{SO}_{2} \cdot \mathrm{R} \cdot 2 \frac{1}{\mathrm{~V}} \cdot \frac{\mathrm{MNNaHCO}_{3}}{\mathrm{MWSO}_{2}} \\
& \mathrm{Q}_{\text {nahcolite }}=3.75 \mathrm{SO}_{2} \cdot
\end{aligned}
$$

where

$$
\begin{aligned}
\mathrm{SO}_{2}= & \text { quantity of } \mathrm{SO}_{2} \text { captured (tons) (see Section } 2 \mathrm{~B} 1.1 \text { ), } \\
\mathrm{R}= & \text { stoichiometric ratio: moles } \mathrm{SO}_{2} \text { :moles nahcolite (assumed to } \\
& \text { be } 1: 1 \text { ), } \\
U= & \text { absorbent utilization (fraction) molar basis (assumed to be } \\
& 0: 70 \text { ). }
\end{aligned}
$$




\section{B.2.2 Solld Waste Produced}

The spent nahcolite in fact weighs less than the original sorbent because of the evolution of $\mathrm{CO}_{2}$ and $\mathrm{H}_{2} \mathrm{O}$ during the reaction with $\mathrm{SO}_{2}$. The reduction 1s about 18\%. The total solid waste $\left(Q_{\text {TSW }}\right)$ is, therefore,

$Q_{\mathrm{TSW}}=3.075 \mathrm{SO}_{2} \cdot$

The solid waste is made up of approximately $1.5 \%$ sodium bicarbonate, 25.47 sodium carbonate, 52.27 sodiu sulfite, and 20.97 sodiu sulfate.

The coefficlents are therefore:

Sodium blcarbonate $\quad 0.046 \mathrm{sO}_{2}$

Sodiun carbonate $\quad 0.781 \mathrm{sO}_{2}$

Sodium sulfite $\quad 1.605 \mathrm{SO}_{2}$

Sodium sulfate $\quad 0.643 \mathrm{SO}_{2}$ 


\section{APPENDIX 2C \\ DESCRIPTION OF COMPUTER MODULE}

The coal-fired power plant computer module consists of a series of five subroutines:BURN, PRECIP, FGDS, OPRINT, and ERRCH. The first three of these are subroutines for each of the three stages in a power plant system - the burner (boiler), precipitator, and FGD systems. The last two are used for output printing and error checks. The module is set to work by a call to subroutine BURN,

CALL BURN (C, BOT, FA, SLUD, GAS, IBLR, IPREC, IFGD, PREFF, SO2EFF, Q), where

C - vector of size 50 with input characteristics of the coal, used for input only (not overwritten);

BOT, FA,

SLUD, GAS = vectors of size 50 with the output characteristics

of the bottom ash, fly ash, FGD sludge, and stack gas, respectively. These vectors are used for output only;

IBLR = boiler type;

IPREC = precipitator indicator. I means there is a precipitator before the FGD system (if any), IPREC = 0 means the FGD system is used as a precipitator to collect $f l y$ ash;

PREFF = the efficiency of the precipitator in removing fly ash, in percent;

SO2EFF = the efficiency of the FGD system in removing $\mathrm{SO}_{2}$;

$Q=$ quantity of coal. 
After calling BURN, the other subroutines will be called internally.

The module has one common block, CBURN, of size 255, which is in all of the subroutines.

A11 of the systems' coefficlents (except for 11me and 1imestone In FGDS, below) are in terms of amount of materlal passing through the respective system, although in the module sometimes the amount of material captured is calculated first. Almost all of the coefficients are read in from a data file, except those that are dependent upon some input value. These w11 be noted in the description of each subroutine, below.

Subrout fne BURN

BURN first sends the calling parameters to ERRCH to check for input errors. It then reads the input coal characteristics into the first 50 elements of CBURN. The composition of the bottom ash and pass-through of all relevant materials are then calculated using the coefficients for the appropriate boller from the data file. BURN then calls PRECIP, FGDS, and OPRINT.

Spec1al Notes:

1) All sulfur not in the bottom ash is assumed to change to $\mathrm{SO}_{2}$ on output (array element 35 (AE35)).

2) All carbon not in the bottom ash is assumed to change to $\mathrm{CO}_{2}$ on output (AE42).

3) $\mathrm{AE} 36$ to $\mathrm{AE} 38\left(\mathrm{NO}_{2}, \mathrm{CO}, \mathrm{CH}_{4}\right)$ are calculated using the total input quantity of coal.

4) The array STACK contalns the emissions from the bollex not including the bottom ash. Hereafter, STACK will be the laput to and output 
from the other system subroutines. Upon output from FGDS, whatever is in STACK is what is considered to go up the power plant stack. BASH contains the bottom ash output from the bofler.

Subroutine PRECIP

PRECIP has all of its pass-through coefficients for ash and trace elements calculated on the basis of precipitator efficiency input. AE36 to $A E 38$ and $A E 42$ are assumed to pass through the prectpitator untouched and have a coefficient of 1 . Sulfur and sludge components are disregarded at this time and have coefficient values of 0 .

\section{Spectal Notes:}

1) PRECIP is called even if IPREC $=0$. If this is the case, the fly ash components are brought into FGDS and used as the respective entries in the sludge output vector.

2) FLY is the fly ash output vector from the precipitator.

Subroutine FGDS

FGDS calculates the amount of ash, trace elements, $\mathrm{SO}_{2}$, and sludge components output from the FGD system.

\section{Speclal Notes:}

1) If there is no precipitator before the FGD system, the values for ash and the trace elements are taken to be the amount calculated in PRECIP. Therefore, the elements in FGD (the sludge output vector) are equated with the respective elements of FLY, and those elements of FLY are set to 0 . 
2) Sludge components ( $\mathrm{AE} 25$ to $\mathrm{AE} 33$ and $\mathrm{AE} 43$ to $\mathrm{AE} 45$ ) are calculated using the amount of $\mathrm{SO}_{2}$ captured in the system.

3) The captured $\mathrm{SO}_{2}$ is determined by SO2EFF, the input FGD system efficiency.

4) No coefficients are avallable for the amounts of some of the trace elements contained in the FGD system lime and 1imestone. These elements are given a coefficient of 0 in LIME or LIMES, and are noted in the output.

Subroutine OPRINT

OPRINT is used to print the output.

Subroutine ERRCH

ERRCH checks that all calling parameters for subroutine BURN are within their correct range and that the sum of the input coal characteristics is not greater than the total quantity of coal. If there are any errors, no calculations are done and control is returned to the calling program.

After all calculations have been made, the output vectors BASH, FLY, FGD, and STACK (which are all within common block CBURN) are equated with other vectors not in the block (BOT, FA, SLUD, and GAS, respectively), and these vectors are passed back to the calling program. 


\section{APPENDIX 2D}

COMPUTER CODE AND SAMPLE OUTPUT

This section sets out the computer code used for the coal combustion module with a sample input and the resulting output. Table 2D.1 gives the coal characteristics used as input. The other input variables used were as follows:

$$
\begin{aligned}
& \text { Quantity of coal }(Q)=100,000.0 \text { tons } \\
& \text { Precipitator efficiency (PREFF) }=99.0 \% \\
& \mathrm{SO}_{2} \text { removal (SO2EFF) }=85.0 \% \\
& \text { Lime wet scrubbing system (IFGD) }=1 \\
& \text { Precipltator employed (IPREC) }=1 \\
& \text { Large pulverized boller (IBLR) }=1
\end{aligned}
$$

The calling program of the code is used only to set the Input variables. In some cases data may be missing and so the output is incomplete.

\begin{tabular}{|c|c|c|c|}
\hline Element & $\begin{array}{c}\text { Input Quantity } \\
\text { (tons) }\end{array}$ & Element & $\begin{array}{c}\text { Input Quantity } \\
\text { (tons) }\end{array}$ \\
\hline $\begin{array}{l}\text { Ash } \\
\text { Sulfur } \\
\text { Antimony } \\
\text { Arsenic } \\
\text { Bery11ium } \\
\text { Cadmium } \\
\text { Chromium } \\
\text { Copper } \\
\text { Iron } \\
\text { Lead } \\
\text { Magnesium }\end{array}$ & $\begin{array}{r}9200.0 \\
1600.0 \\
0.08 \\
1.1 \\
0.2 \\
0.03 \\
1.5 \\
1.6 \\
1000.0 \\
1.09 \\
52.0\end{array}$ & $\begin{array}{l}\text { Manganese } \\
\text { Mercury } \\
\text { Nickel } \\
\text { Selentum } \\
\text { Silver } \\
\text { Thallium } \\
\text { Zinc } \\
\text { Uranium } \\
\text { Thorium } \\
\text { Carbon }\end{array}$ & $\begin{array}{c}20.0 \\
0.014 \\
1.5 \\
0.35 \\
0.02 \\
0.02 \\
1.28 \\
0.11 \\
0.28 \\
72,000.0\end{array}$ \\
\hline
\end{tabular}
An asterisk is used to indicate cases where there were no data on the quantity of an element in the scrubbing media. This means that the amount of the trace element in the FGD sludge may be understated.

Table 2D. 1

Input Characteristics of Coal 
PROGRAM CT ( INPUT, OUTPUT, TAPEI, TAPE9=OUTPUT )

DIMENSION COAL (5O), BASH(50),FLY $(50), S T A C K(50), F G D(50)$

$0=100000.00$

PREFF $\approx 99$.

SOEEFF $=85$.

IFGD $=1$

IPREC $=1$

[BLR=!

$\operatorname{COAL}(1)=9200$.

$\operatorname{COAL}(2)=1600$

$\operatorname{COAL}(3)=0.08$

$\operatorname{COAL}(4)=1.1$

$\operatorname{COAL}(5)=0.2$

$\operatorname{COAL}(6)=0.03$

$\operatorname{COAL}(7)=1.5$

$\operatorname{COAL}(\theta)=1.6$

$\operatorname{COAL}(9)=1000.0$

COAL $(10)=1.09$

$\operatorname{COAL}(1 ;)=52.0$

$\operatorname{COAL}(1 \geq)=20.0$

$\operatorname{COAL}(13)=0.014$

$\operatorname{COAL}(14)=1.5$

$\operatorname{COAL}(15)=0.35$

$\operatorname{COAL}(16)=0.02$

$\operatorname{COAL}(17)=0.02$

$\operatorname{COAL}(18)=1.28$

$\operatorname{COAL}(19)=0$.

$\operatorname{COAL}(20)=0.28$

$\operatorname{COAL}(21)=0$

$\operatorname{COAL}(22)=0$

COAL $(23)=0$

DO $6 \quad 1=24,38$

$\operatorname{COAL}(1)=0$.

6 CONTINUE

COAL $(39)=800$

COAL $(40)=72000$.

$\operatorname{COAL}(4 \mid)=8000000$

DO $7 \quad 1=42.50$

$\operatorname{COAL}(1)=0$.

7 CONT INUE

CALL BURN ICOAL, BASH, FLY, FGD, STACK, IBLR, IPREC, IFGD, PREFF, SOZEFF, Q) STOP

END 
SUBROUT INE BURN(C, BOT , FA, SLUD, GAS, IBLR, IPREC, IFGD, PREFF, SOZEFF, O) COMMON/CBURN/COAL (50), FLY (50), BASH (50), FGD(50), STACK (50), -STAR (3,23)

REAL BCHAR $(4,50), C(50), B O T(50), F A(50), S L U D(50), G A S(50)$

C - COEFF ICIENTS READ IN TO GIVE SPLIT BETWEEEN BOTTOM ASH

- AND FLY ASH READ $(1,1001)((\operatorname{BCHAR}(1, J), J=1,50), 1=1,4)$

1001 FORMAT ( $10 F 7.5)$

C - USED TO STORE COAL CHARACTERISTICS FOR WRITING ON OUTPUT DO $30 \quad I=1,50$ COAL $(1)=C(1)$

30 CONTINHE

C CALCULATION OF RA-226,RA-228 PB-210 IF NOT GIVEN as INPUT DATA IF (COAL (21) .EQ. 0.)COAL $(21)=(3.3 \mathrm{BE}-7)$ "COAL $(19)$

IF (COAL $(22)$.EQ. 0.) COAL $(22)=(4.01 E-10) \cdot \operatorname{COAL}(20)$

IF (COAL (23) .EO. 0.) COAL $(23)=(4.37 E-9)=\operatorname{COAL}(19)$

CALL ERRCH (IELR, IPREC, IFGD, PREFF, SOEEFF, ICHECK, Q)

IF (ICHECK .EQ. 1 JGO TO 500

C - CALCULATION OF ELEMENT SPLit BETHEEN BOTTOM ANO FLy ASH

DO $10 \quad[=1,34$

$\operatorname{STACK}(1)=\operatorname{BCHAR}(I B L R,[)=\operatorname{COAL}(1)$

BASH $(1)=$ COAL ( 1$)-S T A C K(1)$

10 CONT INUE

C CONVERSION OF SULFUR IN STACK GAS TO SOZ

STACK $(35)=B C H A R($ IBLR, 35) *STACK (2)

$\operatorname{STACK}(2)=0$.

C calculation of noe,co ch4 in stack gas

DO $20 \mathrm{~J}=36,38$

STACK $(J)=0 \cdot$ GCHAR (IBLR,J)

$\operatorname{BASH}(J)=0$.

20 CONTINUE

C - CalCULATION OF PYRITIC SUlFuR IN BOTTOM ASH

STACK (39) =BCHAR ( IBLR, 39)*COAL (39)

BASH (39) =COAL $\{39\}-S T A C K(39)$

$\operatorname{STACK}(39)=0$.

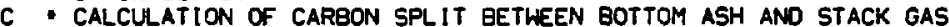

STACK (40) =BCHAR (IBLR, 40) - COAL (40)

BASH $(40)=$ COAL $(40)-S T A C K(40)$

C BTU OUTPUT. SET TO ZERO

STACK $(41)=0$.

BASH $(41)=0$.

C - Conversion of carbon IN STACK gas to cor

STACK $(42)=B C H A R(I B L R, 42) \cdot S T A C K(40)$

$B A S H(42)=0$.

$\operatorname{STACK}(40)=0$.

BASH $(35)=0$.

DO $50 \quad[=43,50$

BASH( 1$)=0$.

STACK ( 1$)=$ BCHAR $(1$ (BLR, 1$) \cdot \operatorname{COAL}(1)$

50 CONTINUE

CALL PRECIP (IPREC, PREFF)

CALL FGDS (IPREC. IFGD, SOZEFF)

CALL OPRINT

DO $40 \quad 1=1,50$

BOT (I) =BASH ( I)

$F A(I)=F L Y(1)$

SLUD (1) =FGD( I)

GAS (1)=STACK (1)

40 CONT INUE

500 RETUPN

END 


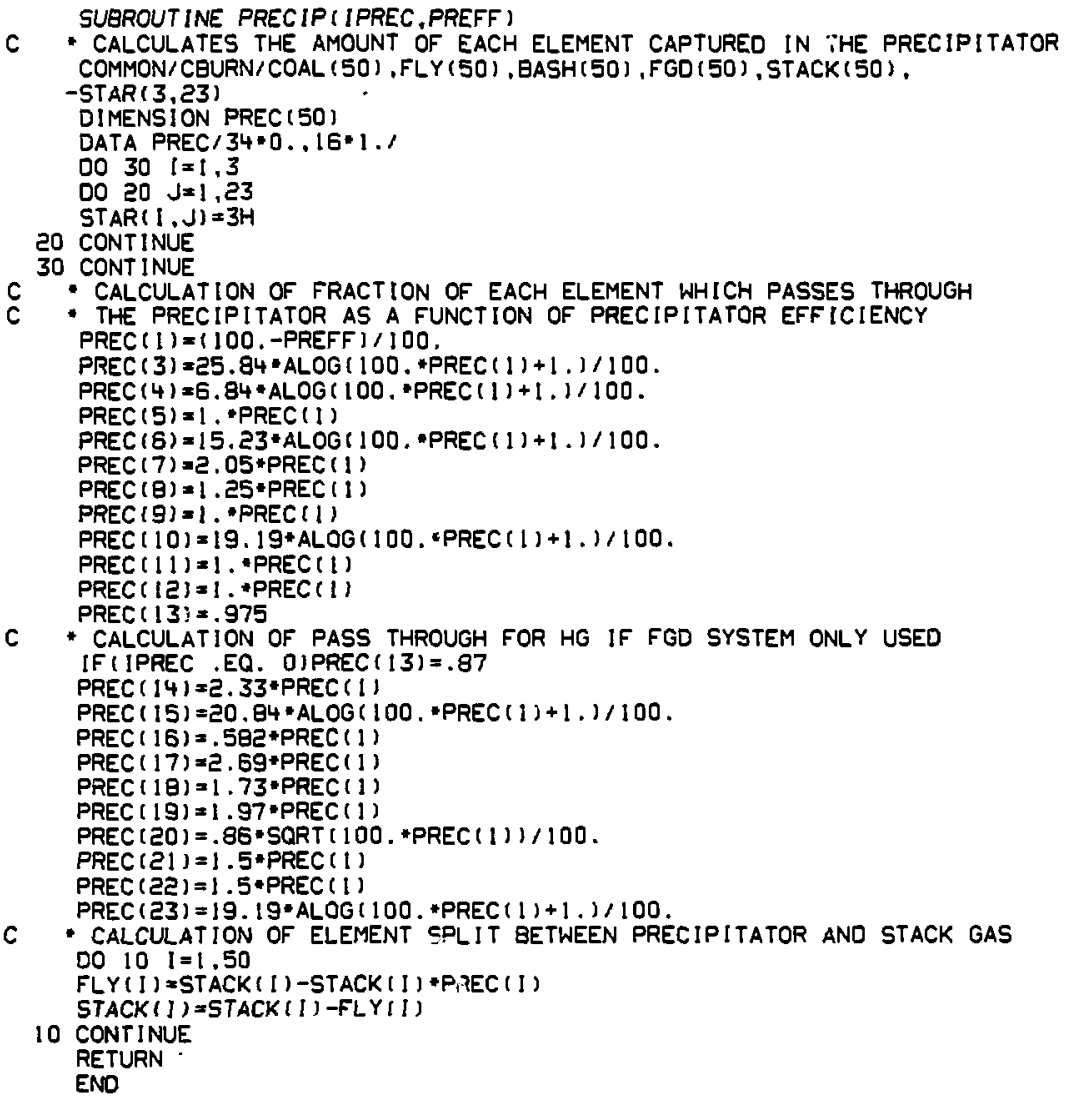


SUBROUT INE FGDS ( IPREC, IF GD, SOZEFF)

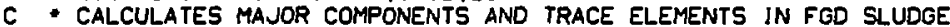
COMMON/CBURN/COAL (50), FLY (50), BASH $(50)$, FGD (50), STACK (50), -STAR (3,23)

REAL FGDC (9,50), LIME (23), LIMES (23)

C READS FROM DATA FILE INPUTT FRACTIONS OF TRACE ELEMENTS

C * IN LIME AND LIMESTONE RESPECTIVELY

READ (1,1001) (LIME (1), I=1,23), (LIMES (I), $1=1,23$ )

c READS IN COEFFICIENTS TO Calculate tHe amount of Each

- ELEMENT IN SLUDGE FOR EACH TYPE OF FGD SYSTEM READ $(1,1002)$ ( (FGOC $(1, J), J=1,50), I=1,9)$

1001 FORMAT (7E 10.3/7E10.3/7E10.3/2E10.31

1002 FORMAT ( 1 OF 7.5 ) IF ( IFGD .EQ. 9) SOEEFF $=0$. FGDC ( IFGD, 35) = SOEEFF $/ 100$ IF I IFREC .EQ. I)GO TO 5

C - if FGo also used as PRECIPITATOR, the saMe fRACTION OF

C EACH ELEMENT AS WOULD BE CAPTURED IN A PRECIPITATOR IS

C ASSUMED CAPTURED IN THE FGD SYSTEM AND APPEARS IN THE SLUDGE DO $4 \quad 1=1,24$ FGD (1)=FLY( I) $F L Y(1)=0$.

4 CONTINUE 60 TO 6

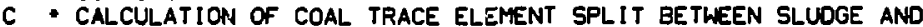

C STACK GAS WHEN A PRECIPITATOR IS USED PRIOR TO THE FGD SYSTEM

5 DO $10 \quad l=1.24$

FGD (I) =STACK (l)-STACK (l)*FGDC (IFGD, !)

STACK (I) $=S T A C K(I)-F G D(I)$

IF I I EO. I) GO TO 10

C - for RegenERABLe SCRUBgers the waSte CONSISTS ONLY OF

C AN 8X REGENERATION LOSS IF (IFGD. EQ. 4 .OR. IFGD .EQ. 5]FGD(I)=.08*FGD(I)

10 CONT INUE

C CALCULATION OF SO2 SPLIT BETHEEN SLUDGE AND STACK GAS

6 FGD $(35)=S T A C K(35) * F G O C$ ( IFGD, 35)

STACK $(35)=S T A C K(35)-F G D(35)$

IF (IFGD. EO. 9)GO TO 7

IF I IFGD .EO. BIGO TO 7

IF IIFGD .EQ. 4 .OR. IFGD .EQ. 5 IGO TO 7

IF IIFGD .EO. 2 .OR. IFGD .EO. 7)GO TO 8

C - Calculation of cuantity of lime REQUiREd for double alkal I IF ( IFGD .EQ. 3)OL IME =.925*FGD (35)

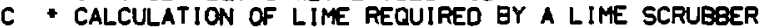
IF IIFGD .EO. I .OR. IFGD .EQ. E)QL IME = .975•FGD(35)

c calculation of tRace ELEMENTS IN SLUDGE FROM LiME

C * If no data aVaIlaBle outPut PRINTS ** DO $9 \mathrm{I}=3,23$ FGD $(1)=F G D(1)+Q L$ IME LLIME (I) IF (LIME II) .EQ. O.JSTAR $(2, I)=3 \mathrm{H}^{*}$

9 CONTINUE GO TO 7

C - CALCULATION OF QUANITY OF LIMESTONE USED IN LIMESTONE

C SCRUBgER AND TRACE ELEMENTS FROM LIMESTONE IN SLUDGE

8 OLIMES $=1.7625 \cdot F G D(35)$

DO 1 I $[=3,23$

$F G O($ I ) $=F G D(I)+Q L$ IMES * LIMES (I)

IF (LIMES (I) .EQ. O.) STAR (2, I ) =3H*

11 CONTINUE

C - CALCULATION OF MAJOR COMPONENTS OF THE FGD SLUDGE

7 DO $20 \quad I=25,33$

FGD (] ) =FGD (35) * FGOC ( IFGD, I)

C - calculation of total waste- het ash + hET SLUDGe 
IF (1 .EQ. 25) FGD (1) =FGD (35) *FGDC ( $[F G D, 1)+2 . * F G D(1)$

C calcllation of total haste het ash + het sludge for

C Regenerable scrubeers

IF (I .EQ. 25 .AND. (IFGD .EQ. 4 .OR. IFGD .EQ. 5) )FGD(I)=

$-F G D(35) * F G D C($ IFGD, 1$)+1.35 * F G D(1)$

C - CalCULATION OF TOTAL WASTE FOR DRY SCUBBer - DRY SLUDGe

C * DRY ASH

IF (I .EQ. 25 .AND. IFGD .EQ, 8)FGD(I)=FGD(35) *FGDC (IFGD, I)+ $-F G D(1)$

20 CONTINUE

C CALCULATION OF WATER IN FGD WASTE

$F G D(34) * F G D(35) * F G D C([F G D, 34)+F G D(1)$

[F( IFGD .EQ. 4 .OR. IFGD .EQ. 5)FGD (34) =FGD(35) \#FGDC (IFGD, 34)+ $-.35 * F G D(1)$

IF(IFGD.EQ. B] FGD (34)=0

DO $30 \quad I=36,38$

$F G D(1)=0$.

30 CONTINUE

DO $40 \quad 1=39,50$

$F G D(1)=F G O C(1 F G D, 1) * F G D(35)$

40 CONTINUE

RETURN

END

SUBROUT INE OPRINT

COMMON/CEURN/COAL (50), FLY (50), BASH(50), FGD(50), STACK (50),

-STAR (3,23)

WRI TE $(9,910)(\operatorname{COAL}(1), \operatorname{BASH}(1), \operatorname{FLY}(1), \operatorname{STAR}(1,1)$,

-FGO(1),STAR(2, 1), STACK(1),STAR(3,1), $1=1,12)$

WRI TE $(9,914)$ (COAL $(1)$, BASH $(1)$.FLY $(1)$,STAR $(1,1), F G D(1)$,

-STAR(2. I) STACK ( 1$), \operatorname{STAR}(3,1), 1=13,23)$

WRI TE ( 9,913$)($ COAL ( I) , BASH (I) , FLY $(1), F G D(I), S T A C K(I), I=24,30)$

WRITE $(9,911)(C O A L(1), B A S H(1), F L Y(1), F G D(1)$, STACK $(1), 1=31,38)$

WRITE $(9,915)$ (COAL ( 1$), B A S H(1), F L Y(1), F G O(1)$, STACK $(1), 1=39,45)$

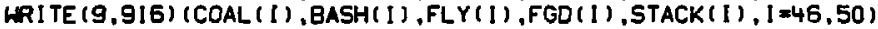
WRI TE $(9.912)$

910 FORMAT(IX. *OMPONENT *T30. INPUT COAL * T45, *BOTTOM ASH*, T6O -FLY A

$-S H *, T 75, * F G D$ SLUDGE*,T90,*STACK GAS*/1X,12(*-*),T30.12(**),T45,

$-12(*-1), T 60,12(*)$, T75, i2 (*), T90,12(*-*),

$-\mid X, * A S H *, T 30,2(E) 12,3,3 X), 3(E 12,3, A 3) /$

$-1 X$. SULFUR*,T30, $2(E \mid 2.3,3 X), 3(E) 2.3, A 3)$

$-1 X, * A N T I M O N Y *, T 30,2(E I 2,3,3 X), 3(E 12,3, A 3) /$

$-1 X,-A R S E N I C *, T 30,2(E I 2,3,3 X), 3(E I 2: 3, A 3) \prime$

- IX, -BERYLLIUM-, T30,2(E) $2.3,3 X), 3(E), 3, A 3) /$

$-1 X$. CADMIUM* T30,2(E12.3,3X), 3(E12.3,A3)/

-1X, CHROMIUM , T30,2(E12.3,3x;,3(E12.3,A3)/

-1X." COPPER*,T30.2(El2.3.3X).3(El2.3,A3)/

$-1 X$-IRON , T30.2(EI2.3, 3X), 3(EI2.3,A3)/

$-1 X$, "LEAD., T30,2(EI2, 3,3X), 3(EI2, 3,A3)/

- $\mid X$. MAGNESIUM*.T30,2(E12.3,3X),3(E12.3,A3)/

$-\mid X$. MANGANESE*, T30, $2(E 12.3,3 X), 3(E 12.3, A 3))$ 
914 FORMAT ( IX, MERCURY* T30,2(E12.3.3X),3(E12.3.A3)/

$-1 X$.NICKEL , T30,2(E) $2,3,3 X), 3(E \backslash 2,3, A 3) /$

$-1 X$. .SELENIUM*.T30, $2(E), 2,3,3 X), 3(E) 2,3, A 3) /$

-IX. SILVER*, T30, $2(E \mid 2,3,3 X), 3(E) 2,3, A 3) /$

$-1 X$. THALLIUM*, T30,2(E) $2,3,3 X), 3(E, 2,3, A 3) /$

$-\{X, \cdot Z I N C *, T 30,2(E) 2.3,3 X), 3(E I 2.3, A 3)$,

- $\mid X$, URANIUM-23日", T30, $2(E) 2.3,3 X), 3(E) 2.3, A 3)$,

$-1 X_{1} \cdot$ THORIUM-232", T30,2(EI2.3,3X),3(EI2.3,A3)।

$-(X, \cdot R A D I U M-226 *, T 30,2(E) 2.3 .3 X), 3(E \mid 2.3, A 3) /$

$-\{X, * R A D I U M-228 *, T 30,2(E I 2.3,3 X), 3(E) 2.3, A 3\} /$

$-1 X$, LEAD-210* T30,2(E12.3,3X), 3(E12.3,A3))

913 FORMAT $11 X$, "HYDROCARBONS*.

$-T 30,5(E 12,3,3 X) / 1 X$, TOTAL FGD SLUDGE*,T30,5(E12,3,3X)/1X,

- +UNREACTED L IMESTONE *.

$-T 30,5(E 12.3,3 X) / 1 X, * C A L C I U M$ SULFITE , T30, 5(EIZ.3

$-, 3 X) / 1 X$. "CALC IUM SULFATE*,T30,5(EI2.3,3X)/1X,*SODA-ASH*, T30,

$-5(E 12.3,3 X) /(X$. MAGNESIUM SULF $I T E \cdot T 30,5(E 12.3,3 X))$

911 FORMAT $(I X$.MAGNESIUM OXIDE T T30, $12.3,3 X)$

$-\mid X$, SODIUM BISULF:TE.T30.5(E) $2.3,3 x) /$

$-\{X$, .SODIUM SULFITE*.T30,5(E) $12,3,3 x\}$

$-\mid X, \bullet$ WATER*, T30,5(EI2,3,3X)।

$-\mid X$, SULFUR DIOXIDE*.T30,5(E) $12,3,3 X) \mid$

$-\mid X$. -NITROUS OXIDES*.T30,5(E) $2.3,3 X) /$

$-1 X$, .CARBON MONOXIDE*,T30.5(E) $2.3,3 X) /$

- IX, - ME:THANE* T30,5(E) $2.3,3 X)\}$

915 FORMAT (1X, *PYRITIC SULFUR*,T30,5(E) $2.3,3 X)$

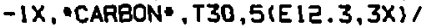

- $1 X$, , BTU CONTENT , T30,5(E) $12,3,3 X) /$

-1X. "CARBON DIOXIDE*,T30,5(EIL.3,3X)

-IX. "SOOIUM BICARBONATE",T30,5(E⿰氵).3,3X)/

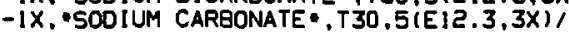

$-1 X$. SOOIUM SULFATE*.T30.5(E12.3.3X)

916 FORMAT ( $[X$, "EMPTY , T30,5(EI2. $3,3 x)$ )

-IX. EMPTY",T30, $5(E 12,3,3 X) /$

$-\mid X$. "EMPTY", T30.5(E) $2,3,3 X)$,

-IX. "ЕMPTY.,T30.5(E!2.3,3X)1

- IX. EMPTY ,T30,5(E) $2.3,3 X) / 1)$

912 FORMAT(IX, IH*, ACTUAL OUANTITY UNCERTAIN DUE TO UNKNOWN AMOUNT ADD -ED FROM LIME/LIMESTONE IN FGD SCRUBBER. "/)

RETURN

END 
SUBROUT INE ERRCH [ IBLR, IPREC, IFGD, PREFF, SOEEFF, ICHECK, Q]

C USED TO ENSURE INPUT DATA WITHIN CORRECT BOUNDS COMMON/CBURN/COAL \{50\}

ICHECK=0

C - BOILER TYPE MUST BE AN INTEGER FIGURE BETWEEN 1 AND 4 DO $10 \quad l=1,4$

IF (IBLR.EO. I)GO TO 20

10 CONTINUE

ICHECK $=1$

WRI TE $(9,901)$ I BLR

C - IPREC FLAG IS EITHER O FOR NO PRECIPITATOR OR 1 FOR PRECIPITATOR

20 IF IIPREC .EO. O .OR. IPREC .EO. I)GO TO 40 ICHECK $=1$

WRI IE (9,902) IPREC

C + FGD SYSTEM INPUT INTEGER BETWEEN 1 AND 9 AND MUST $B E$

C COMPATIELE WITH PRECIPITATOR OR NO PRECIPITATOR

40 DO $60 \quad i=1,9$

IF (IFGD . NE. I)60 TO 60

IF I IFGD .LE. 5 . AND. IPREC .EQ. IIGO TO 50

IFIIFCD .EO. 9 .AND. IPREC .EQ. 1$) G 0$ TO 50

IF IIFGD .GE. 6 .AND. IPREC .EQ. OJGO TO 50

60 CONTINUE

ICHECK $=1$

WRI TE $(9,904)$

C - PRECIPITATOR EFFICIENCY MUST BE BETWEEN O AND $100 x$

50 IF (PREFF. GE, 0 . . AND. PREFF .LE. 100.)G0 TO 70 ICHECK $=1$

WRI TE $(9,905)$

C * SOZ REMDVAL RATE MUST BE BETHEEN D AND 100X

70 IFISOZEFF .GE. O. .AND. SOZEFF. LE. 100.1G0 TO 80 ICHECK $=$ I

WRI TE $(9,906)$

C - SUM OF ELEMENTS IN COAL CANNOT BE GREATER tHAN TOTAL

C DUANTITY OF COAL

80 CSUM $=0$.

DO $90 \quad i=1,24$

CSUM $=$ CSUM+COAL (1)

90 CONTINUE

IF $(Q$. GE. CSUM)GO TO 100

ICHECK $=1$

WR I TE $(9,907)$

C IF iCHECK=I No Calculations made and erRor message printed

901 FORMAT(1X,*THERE IS NO BOILER TYPE* $13 / 1)$

902 FORMATIIX, $13,1 \mathrm{X}$, IS NOT A VALID PRECIPITATOR PARAMETER IONLY 0 OR $-1) * 11\}$

904 FORMAT (IX, YYO HAVE ENTERED AN INCORRECT FGD TYPE OR AN INCORRECT -PRECIPITATOR/FGO PARAMETER MATCHUP* $/ 1$

905 FORMAT (IX, PRECIPITATOR EFFICIENCY IS NOT IN THE INTERVAL $(0,100)$. $-* / 1)$

906 FORMAT (1X. -FGD SYSTEM SOZ REMOVAL EFFICIENCY IS NOT IN THE INTERVA $-L(0,100)+11)$

907 FORMAT ( $1 X_{*}$ *THE SUM OF THE CHARACTERISTICS OF THE INPUT COAL IS GRE -ATER THAN THE TOTAL INPUT COAL. $* / 1)$

100 RETURN

END 


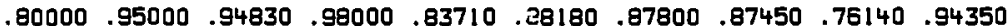
$\begin{array}{llllllll}.82550 .84660 & .98720 & .84220 .98820 & .94490 .88070 .88630 & .69970 .80190\end{array}$ .80000 .80000 .943501 .000001 .000001 .000001 .000001 .000001 .000001 .00000 1.000001 .000001 .000001 .090002 .00000 .00900 .00050 .00015 .95000 .98000

1.000003.670000.000000.000000.000000.000000.000000.000000.000000.00000 $\begin{array}{llllllll}.40000 & .95000 & .91660 & .82710 .41800 & .81440 & .54150 .68920 & .39460 & .92560\end{array}$ $\begin{array}{llllll}.37860 .37220 & .98770 .73770 .80660 .78000 & .97390 & .92880 .54240 .38740\end{array}$ .40000 .40000 .925601 .000001 .000001 .000001 .000001 .000001 .000001 .00000 1.000001 .000001 .000001 .000002 .00000 .02750 .00050 .00015 .95000 .98000

1.000003.670000.000000.000000.000000.000000.000000.000000.000000.00000 $\begin{array}{ll}.65000 .95000 .94830 .98000 .83710 .88180 & .87800 .87450 .76140 .94350\end{array}$ $\begin{array}{llllll}.82550 .84660 & .98720 .84220 .98820 & .94490 .88070 .88630 .69970 .80190\end{array}$ .65000 .65000 .943501 .000001 .000001 .000001 .000001 .000001 .000001 .00000 1.000001 .000001 .000001 .000002 .00000 .00750 .00100 .00500 .95000 .98000

1.000003 .670000 .000000 .000000 .000000 .000000 .000000 .000000 .000000 .00000

.10000 .95000 .91650 .82710 .41800 .31440 .54150 .69920 .39460 .92560 $\begin{array}{llllll}.37860 & .37220 & .98770 .73770 .80660 & .78000 .97390 & .92880 & .54240 .38740\end{array}$ .10000 .10000 .925601 .000001 .000001 .000001 .000001 .000001 .000001 .00000 1.000001 .000001 .000001 .000002 .00000 .00300 .00500 .00150 .95000 .98000 1.000003.670000.000000.000000.000000.000000.000000.000000.000000.00000 0 0.0 $190 E-05$ 174E-04 0 . 0 . 0 . 0 . 0 .

.169E-05 827E-06 0 .

0.0

0 . $.627 E-07$ 0 . $.150 E-05$ $.180 E-08 \quad .337 E-07$ 3iटE-05

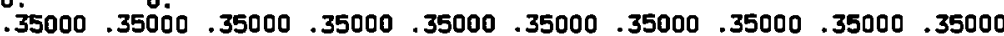

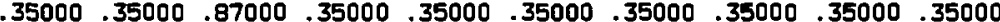
.35000 .35000 .350000 .000004 .72800 .174001 .51600 .674000 .000000 .00000 0.000000 .000000 .000002 .364000 .000000 .000000 .000000 .000000 .000000 .00000

0.000000 .000000 .000000 .000000 .000000 .000000 .000000 .000000 .000000 .00000 .35000 .35000 .35000 .35000 .35000 .35000 .35000 .35000 .35000 .35000 .35000 .35000 .87000 .35000 .35000 .35000 .35000 .35000 .35000 .35000 .35000 .35000 .350000 .000004 .69700 .352501 .36500 .631000 .000000 .00000

0.000000 .000000 .000002 .348500 .000000 .000000 .000000 .000000 .000000 .00000

0.000000 .000000 .000000 .000000 .000000 .000000 .000000 .000000 .000000 .00000

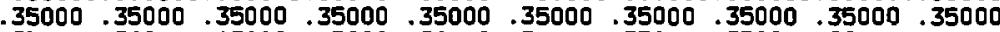
.35000 .35000 .87000 .35000 .35000 .35000 .35000 .35000 .35000 .35000 .35000 .35000 .350000 .000004 .65180 .082901 .51800 .67500 .050000 .00000

0.000000 .000000 .000002 .325900 .000000 .000000 .000000 .000000 .000000 .00000

0.000000 .000000 .000000 .000000 .000000 .000000 .000000 .000000 .000000 .00000 .35000 .35000 .35000 .35000 .35000 .35000 .35000 .35000 .35000 .35000 .35000 .35000 .87000 .35000 .35000 .35000 .35000 .35000 .35000 .35000 .35000 .35000 .350000 .00000 .153900 .000000 .000000 .000000 .00000 .08125 .018790 .000000 .00000 .053870 .000000 .000000 .000000 .000000 .000000 .00000 0.000000 .000000 .000000 .000000 .000000 .000000 .000000 .000000 .000000 .00000 .35000 .35000 .35000 .35000 .35000 .35000 .35000 .35000 .35000 .35000 .35000 .35000 .87000 .35000 .35000 .35000 .35000 .35000 .35000 .35000 .35000 .35000 .350000 .00000 .215800 .000000 .000000 .000000 .000000 .00000 
0.00000 .08125 .05902 .075530 .000000 .000000 .000000 .000000 .000000 .00000 0.000000 .000000 .000000 .000000 .000000 .000000 .000000 .000000 .000000 .00000 $0.000000 .000000 .000000 .000000 .000000 .000000,000000.000000 .000000 .00000$ 0.000000 .000000 .000000 .000000 .000000 .000000 .000000 .000000 .000000 .00000 0.000000 .000000 .000000 .000004 .72800 .174001 .51600 .674000 .000000 .00000 $0.000000 .000000 .000002 .364000 .000000 .000000,000000.000000 .000000 .00000$ 0.000000 .000000 .000000 .000000 .000000 .000600 .000000 .000000 .000000 .00000 0.000000 .000000 .000000 .000000 .000000 .000000 .000000 .000000 .000000 .00000 0.000000 .000000 .000000 .000000 .000000 .000000 .000000 .000000 .000000 .00000 0.000000 .000000 .000000 .000004 .69700 .352501 .36500 .631000 .000000 .00000 0.000000 .000000 .000002 .348500 .000000 .000000 .000000 .000000 .000000 .00000 0.000000 .000000 .000000 .000000 .000000 .000000 .000000 .000000 .000000 .00000 0.000000 .000000 .000000 .000000 .000000 .000000 .000000 .000000 .000000 .00000 0.000000 .000000 .000000 .000000 .000000 .000000 .000000 .000000 .000000 .00000 0.000000 .000000 .000000 .000003 .075000 .000000 .000000 .000000 .000000 .00000 0.000000 .00000 .643000 .000000 .000000 .000000 .000000 .000000 .000000 .00000 0.000000 .00000 .04600 .781001 .605000 .000000 .000000 .000000 .000000 .00000 1.000001 .000001 .000001 .000001 .000001 .000001 .000001 .000001 .000001 .00000 1.000001 .000001 .000001 .000001 .000001 .000001 .000001 .000001 .000001 .00000 1.000001 .000001 .000001 .000000 .000000 .000000 .000000 .000000 .000000 .00000 0.000000 .000000 .000000 .000000 .000000 .000000 .000000 .000000 .000000 .00000 0.000000 .000000 .000000 .000000 .000000 .000000 .000000 .000000 .000000 .00000 


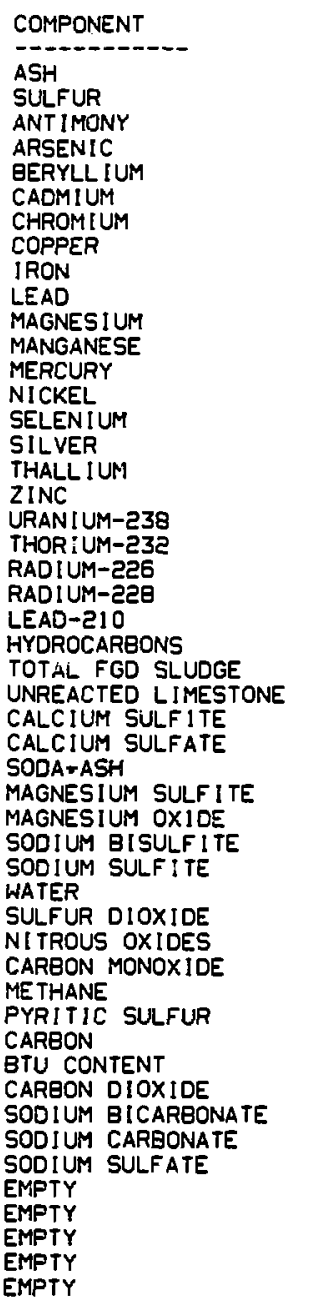

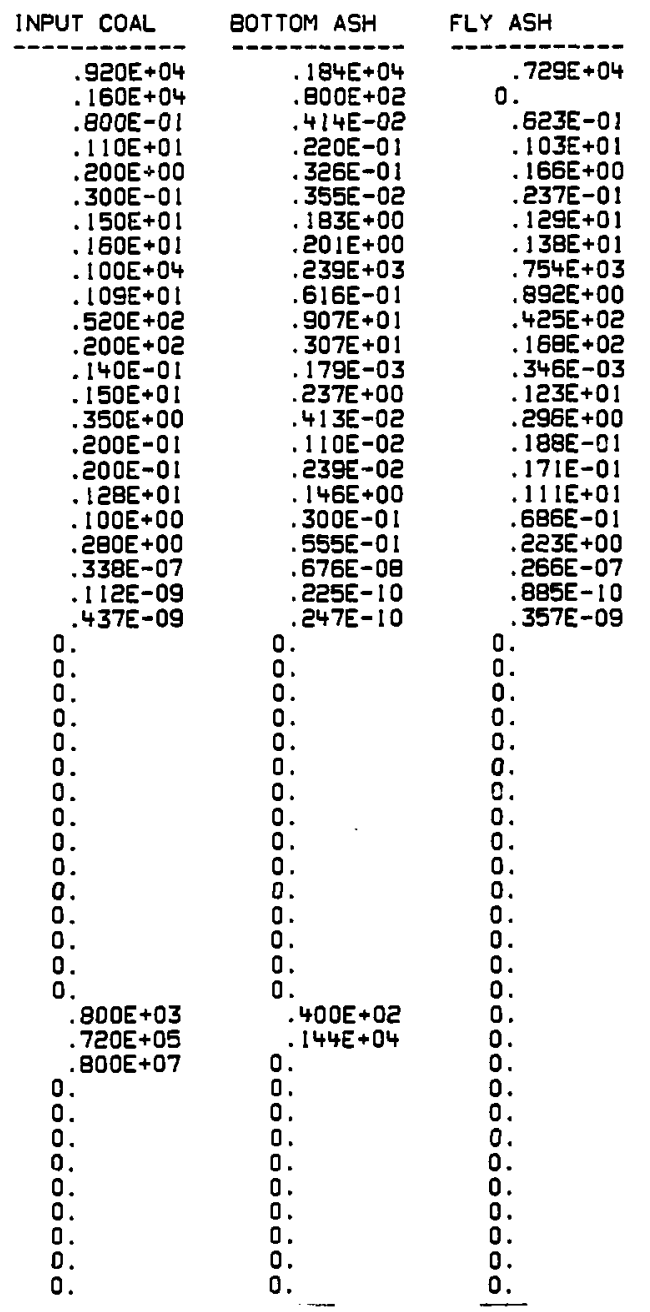

FGD SLUDGE

$.893 E-02 *$

370E-01

$.109 E-02$

$.190 \mathrm{E}-02$

$.254 E-01$

$.162 E-01$

$495 \mathrm{E}+01$

$.894 E-01$

$196 E+02$

$501 E+00$

$.175 E-02 *$

19IE-0I.

763E-0I

$.715 E-04 *$

308E-03.

$.507 E+00$

$.896 \mathrm{E}-03$.

$126 E-02$.

.264E-09.

876E- 12 .

0 .

$356 E-10$.

$.123 E+05$

$450 E+03$

उ92E+04

$.174 E+04$

0 .

0 .

0.

$.616 E+04$

$.258 E+04$

0.
0.
0.
0.
0.
0.
0.
0.
0.
0.
0.
0.
0.
0.
0.
STACK GAS

$.476 E-02$

$179 E-01$

.586E-03

$.977 E-03$

$.945 E-02$

. $612 E-02$

. $266 E+01$

479E- 01

$.150 E+00$

593E-01

. $\mid 17 E-01$

$.103 E-01$

$.175 E-01$

$.385 E-04$

$166 E-03$

.6B7E-02

.482E-03

676E-03

$.142 E-09$

$.472 E-12$

$.192 E-10$

0 .

0.

0.

0.

0.

0 .

$.456 E+03$

$900 E+03$

$.500 E+02$

0 .

$150 E+02$

0 .

$.259 E+06$

0.

0 .

0 .

0 .

0.

0 .

*aCtUAL QUANTITY UNCERTAIN DUE to UNKNOWN AR:OUNT ADDED FROM LIME/LIMESTONE IN FGD SCRUBBER. 
3 SOLID WASTE MODULE FOR ATMOSPHERIC FLUIDIZED BED COMBUSTION

\subsection{Introduction}

Atmospheric fluidized-bed combustion (AFBC) is an advanced conbustion technique in which crushed coal burns in the presence of crushed limestone while held in suspension by upward-flowing combustion air. The technique has several advantages. Rapid heat transfer and high heat-release rates at a reduced temperature can be obtained, so that boiler tubes can be embedded in the combustion zone, resulting in smaller boilers. Fluidized-bed boilers can be fired with all grades of coal without serious modification. Further, the limestone acts as a sorbent to chemically remove $\mathrm{SO}_{2}$ directly from the combustion zone, thus making AFBC an alternative to conventional combustion with FGD in order to comply with the stringent new $\mathrm{SO}_{2}$ regulations.

Despite the advantages of the AFBC process, there are no commercial units now in operation. Industry representatives consider the bollers a high risk because their rellabllity and cost effectiveness for heavy loads have not been demonstrated.

\section{2 General Description of a Utility AFBC Process}

The DOE is sponsoring a program to develop conceptual designs for a nominal 600-MW utility AFBC steam generating plant in order to obtain the design information necessary for a demonstration effort. Three conceptual designs are being developed under this program by the following teams:

Burns and Roe/Combustion Engineering

Stone and Webster/Foster Wheeler Energy Corporation

Stone and Webster/Babcock and Wilcox 
Although there are major differences between the three plans in the engineering details, the overall designs are very similar for the purpose of calculating the solid waste produced. Figure 3.1 is a schematic diagran of the AFBC boller system used in the module.

The combustion of coal is carried out in two stages. The first stage is the main fluidized bed where most of the carbon is burned. The second stage is called the carbon burnup cell ( $C B C)$. The elutrlated particles from the main bed are removed from the flue gas by the primary cyclone and returned to the $\mathrm{CBC}$, where the combustion of the carbon present in these particles can take place. The elutrlated particles can also be returned to the main bed. However, it is more difficult to obtain the same efficlency as with two stage combustion. All the proposed designs use a $\mathrm{CBC}^{1}$.

The heat released by the burning of the feed coal is transferred to water/steam in tubes surrounding and submerged in the bed.

The flue gas streams from the main bed and CBC, after passing through cyclones, pass through an air heater where the input air to the main bed and CBC is heated to $600^{\circ} \mathrm{F}$. The flue gas, after being cooled to about $250^{\circ} \mathrm{F}$, passes through a baghouse filter for final cleaning.

This is the cleanup system proposed by Combustion Engineering and Foster Wheeler; at present, Babcock and Wilcox propose using electrostatic preclpitators. Although this would help protect the air heater, it is an unproven ESP application. The collection could be hampered by the presence of calclum-based particulate components and also by low $\mathrm{SO}_{2}$ concentrations in the flue gas ${ }^{1}$. 


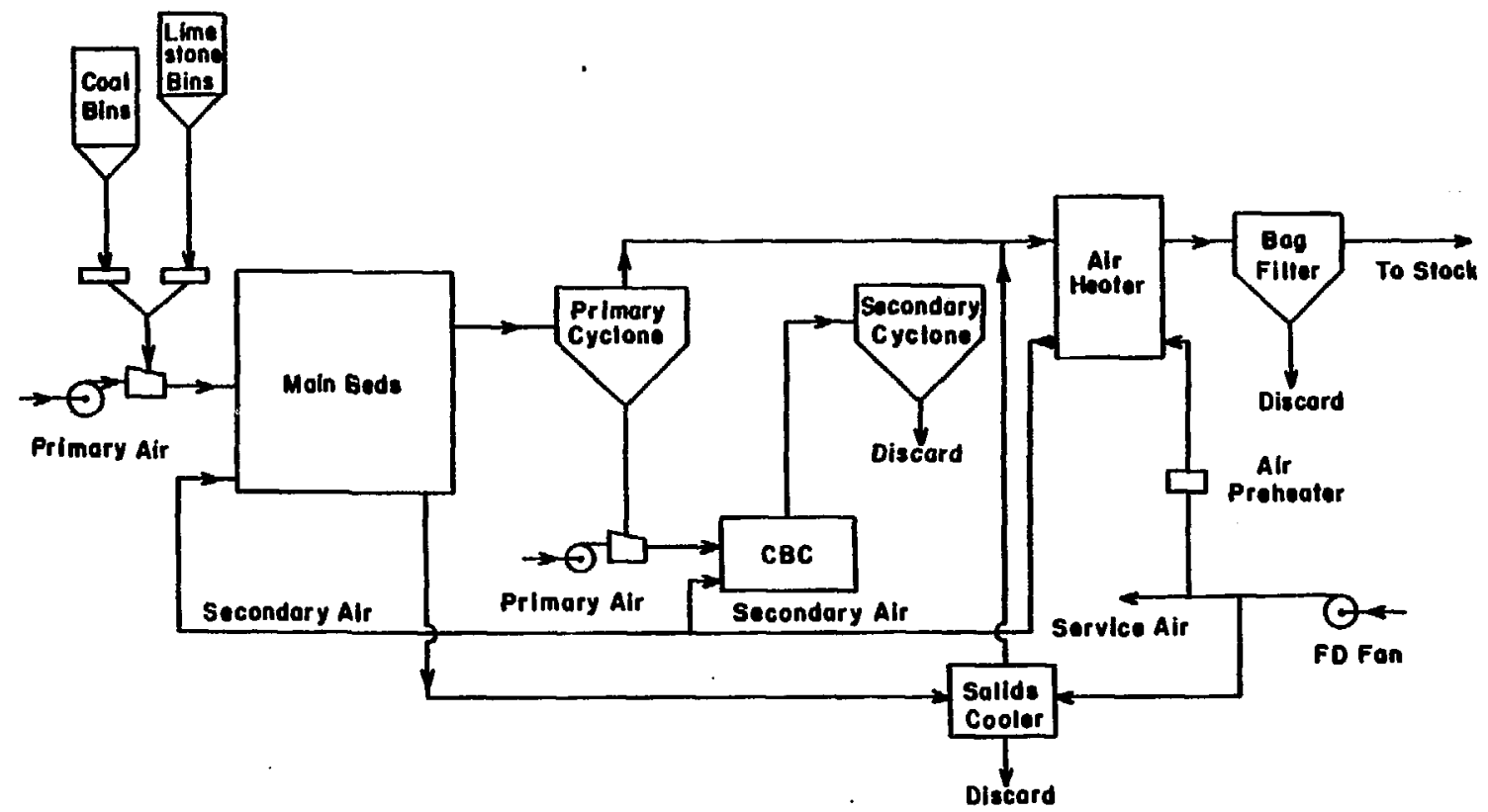

Figure 3.1 AFBC Conceptual Plant Design 
The solids discharged from the main bed are discarded after recovering some of their sensible heat by cooling them with air. The solids obtained from the secondary cyclone and baghouse are also discarded.

The operating conditions of an AFBC process can vary widely and have a significant Influence on the amount of solid waste produced. One influential variable is bed temperature, however, all three proposed designs assume $1550^{\circ} \mathrm{F}$ and $2000^{\circ} \mathrm{F}$ in the main bed and $\mathrm{CBC}$, respectively ${ }^{1}$.

The superficlal velocity and bed height, or in other words the residence time, are critical as far as sulfur capture and limestone consumption are concerned. For the same sulfur removal the limestone requirement increases with increasing superficial velocity. In addition, the carbon consumption efficiency may decrease with increasing velocity. However, the bed area would be smaller if the velocity were larger. This would result in a smaller number of feeding points and possibly some saving in boiler cost.

\section{3 Solid Waste Production}

Fluldized-bed combustion produces two distinct types of solid waste, the elutrlated fines that are captured by the particulate equipment and the coarser materlal that is extracted directly from the main bed drains. The spent bed materlal is expected to be composed mainly of $\mathrm{CaSO}_{4}, \mathrm{CaO}$, and inert mineral impurities in the 1imestone. The elutriated fines consist of ash, unburnt carbon, and spent bed material. There will be trace metals in all waste streams originating from both the coal and the limestone.

The total quantity of ash in the solid waste depends on the ash content. of the coal and the efficiency of the precipitators, which is dictated by air 
pollution regulations. The amount of spent sorbent material depends on a mach greater number of factors, including:

Fuel sulfur

Sulfur reduction required

Reactivity of the limestone

Particle size of the limestone

Bed temperature

Bed height

Bed velocity

A number of these factors can be "lumped" into a single operating parameter, the calclum to sulfur feed ratio ( $\mathrm{Ca} / \mathrm{s})$, which greatly simplifies the calculation of the quantity of waste generated. At present, the only simple equation avallable, developed by IR\&T ${ }^{2}$, takes into account only sulfur removal rate, bed height, and bed velocity. Bed temperature is not included as a variable. However, this is expected to be reasonably constant amongst utility-sized AFBCs. The greatest weakness in the equation is that it is based on experiments conducted using only one type of limestone, and therefore differences in limestone reactivity are not taken into account. This can vary widely and will affect the $\mathrm{Ca} / \mathrm{S}$ ratio. At present, however, there is no explanation as to why one limestone is more reactive than another, and no methods to predict reactivity have been developed 4 . Therefore, even with its limitations the equation would appear to be the best avallable.

The rate of elutriation of the waste from the main bed will vary depending on the operating conditions of the AFBC. For the module, the assumptions given in the Combustion Engineering design are used ${ }^{3}$. 
$100 \%$ input coal ash

$40 \%$ spent bed material

$10 \%$ Input coal carbon

An elutriation rate of $40 \%$ for the spent material is assumed for all present designs ${ }^{1}$. Combustion Engineering and Foster Wheeler both assume $100 \%$ elutriation of the ash; Babcock and Wilcox assumes $75 x^{1}$.

The quantity of the elutriated waste captured will depend on the efficlency of the collection devices. In the module the two cyclones will have pre-set removal rates of $90 \%$ and $80 \%$ respectively. These are the figures used in Combustion Engineering's design ${ }^{3}$. The material collected in the first cyclone goes to the $C B C$, while that from the second cyclone is discarded as waste. The final baghouse collector will be of varying efficiency. The efficlency will be set internally in the module depending on the loading and the final allowable emissions to comply with air regulations. The allowable emissions w1l be given as an input.

The carbon balance depends on the combustion efficiency and the module assumes $90 \%$ efficlency in both the main bed and the CBC. These figures are from the Combustion Engineering design ${ }^{3}$.

The solid waste streams will contain trace metals from both the coal and the limestone. However, no complete data are yet avallable on the distribution of the trace metals between the different waste streams. Little work has been done concerning the fate of trace metals during AFB combustion, and no satisfactory estimate of the constituents of the AFB waste can be projected 5 . A survey was made of the National Technical Inforamtion Service (NTIS) abstracts for the last three years, and very few reports were found which addressed the problem. Swift and Vogel of ANL have looked at the fate 
of trace elements during fluidized-bed combustion using a pressurized system ${ }^{6}$. Trace element measurements have been made by members of the Lovelace Research Institute using the Morgantown Energy Research atmospheric fluidized bed, 7 but only the concentrations of trace elements are given. Dr. Kovach and $\mathrm{Dr}$. Abel of the Morgantown facility sent backup data, but these were not detailed enough to calculate mass balances for the trace elements. A further report is being prepared which may contain additional data to enable mass balances to be determined. Therefore, at present, no attempt has been made to distribute the trace metals between the various output waste streams. The module is set up so that coefficients can easily be added when data become available.

\subsection{AFBC Module Description}

The module computes the air and solid waste residuals which result from the combustion of coal in a utility AFBC boiler. Figure 3.2 gives the overall view of the module design. The module is called with the following arguments.

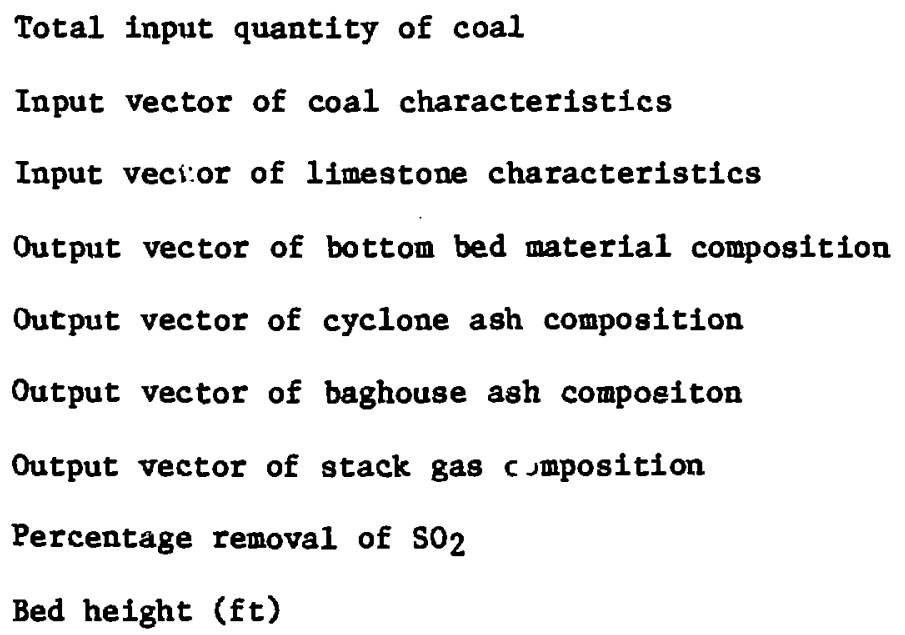




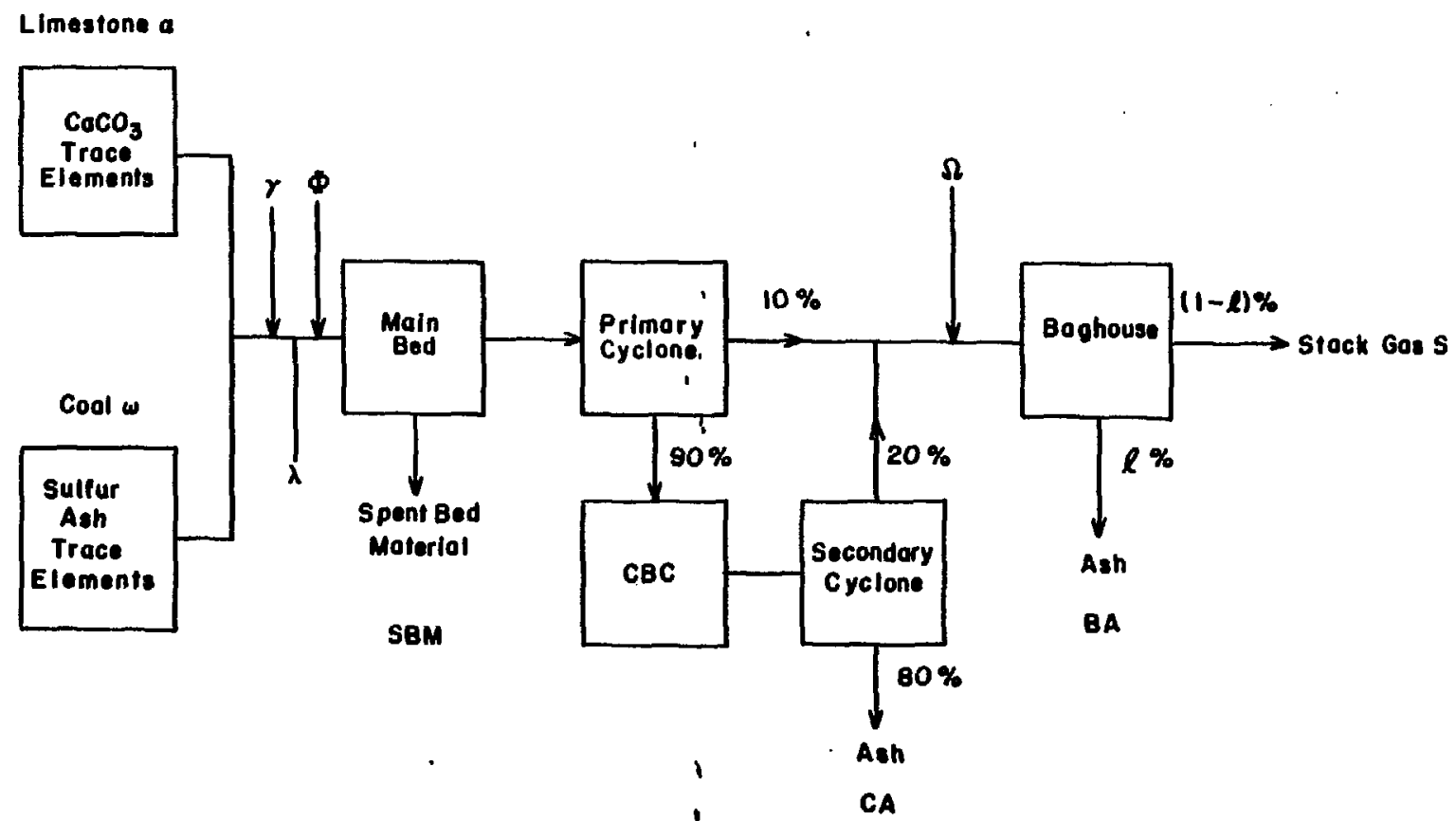

Figure 3.2 Overall AFBC Module Design 
Notation for F1gure $\mathbf{3 . 2}$

INPUTS

$\omega \quad$ Coal characteristics (expressed as tons)

a. Iimestone characteristics (expressed as percentages)

$\lambda$ Percentage removal of $\mathrm{SO}_{2}$

$\gamma \quad$ Bed height ( $f t$ )

$\Phi$. Bed velocity (ft/sec)

$\Omega$ Allowable particulates enissions (tons/1012 Btu)

\section{OUTPUTS}

$\ell$ Percentage removal of particulates

SBM Amount and composition of spent bed material

CA Amount and composition of the particulates captured by the secondary cyclone

BA Amount and composition of the particulates captured by the baghouse

S Composition of stack gas 
Bed velocity (ft/sec)

Allovable particulate emissions (tons/1012 Btu input)

The Input and output vectors each contain 50 elements (Table 3.1). Since these vectors are constructed to be conformable to any of the solid waste modules which have been produced, there are presently some empty elements (48 to 50, not shown in Table 3.1) and some elements not applicable to this module, which are disregarded (set to 0 ) in the output vectors and omitted in the output printout.

The input and output vectors give the amount of each element in tons, the exception being the Input Ifmestone vector. In this case the elements are given in terms of percentage composition because the total quantity of limestone is calculated internally in the module.

The module first calculates the $\mathrm{Ca} / \mathrm{S}$ ratio using the following equation:

$$
\mathrm{Ca} / \mathrm{S}=\frac{0.3782 \mathrm{e}^{2.14 \eta \mathrm{SO}}{ }_{2}}{\sqrt{(\mathrm{B} / \mathrm{V})}},
$$

where

$$
\begin{aligned}
\mathrm{SO}_{2} & =\text { removal percentage } \mathrm{SO}_{2}, \\
\mathrm{~B} & =\text { bed helght }(\mathrm{ft}), \\
\mathrm{V} & =\text { superfictal velocity }(\mathrm{ft} / \mathrm{sec}) .
\end{aligned}
$$

From this, the total quantity of limestone required can be computed using the equation given in Table 3.2. The amount of each element in the Iimestone can then be computed. The $\mathrm{CaCO}_{3}$ in the limestone reacts with the $\mathrm{SO}_{2}$ according to the reactions given below.

$$
\begin{gathered}
\mathrm{CaCO}_{3} \longrightarrow \mathrm{CaO}+\mathrm{CO}_{2} \\
\mathrm{CaO}+\mathrm{SO}_{2}+\stackrel{1}{-} \mathrm{O}_{2} \longrightarrow \mathrm{CaSO}_{4}
\end{gathered}
$$




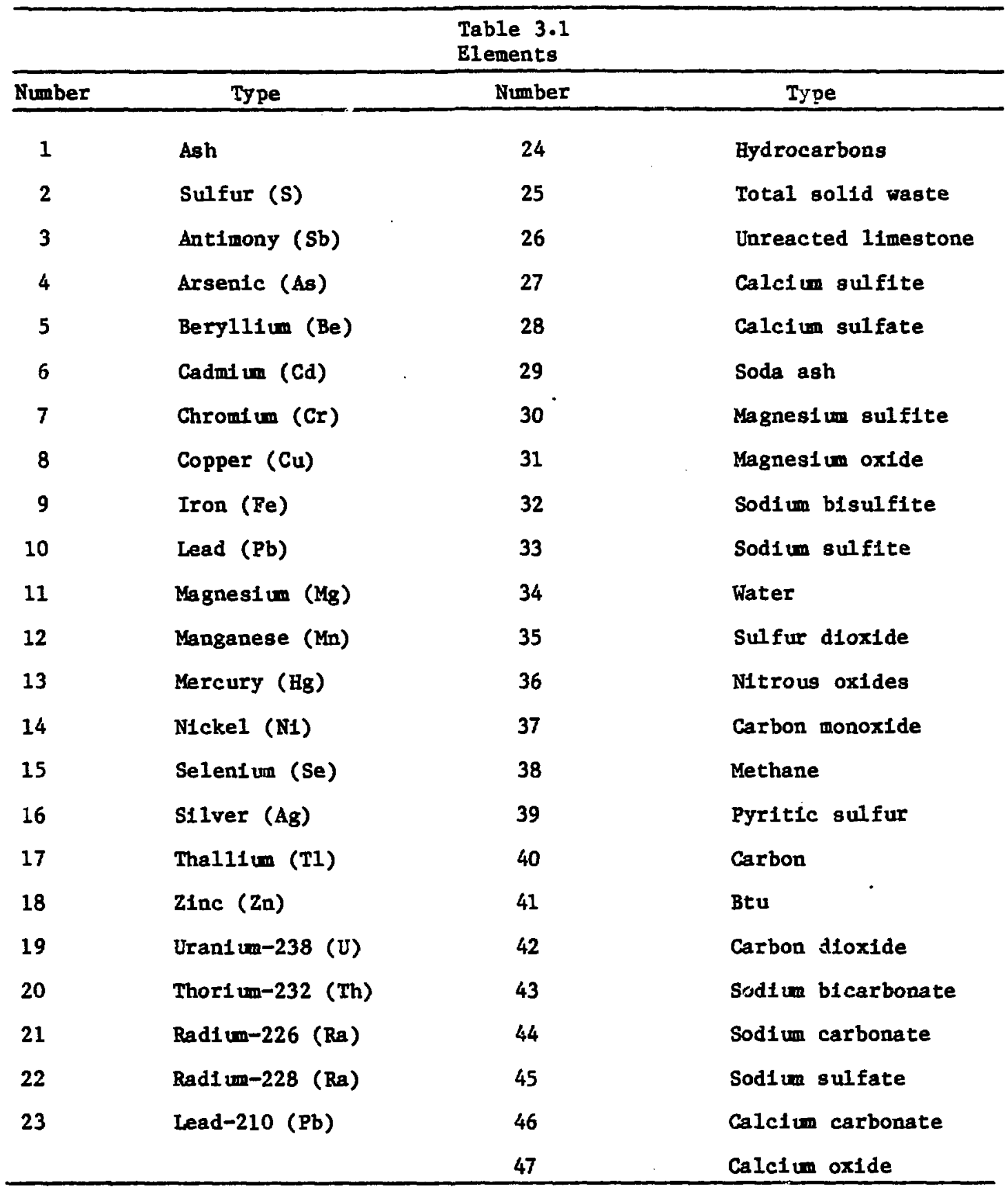


Table 3.2

Composition of Spent Sorbent Material

\begin{tabular}{|c|c|}
\hline Component & Equation \\
\hline Ifmestone (QLS) & $(3.125 \times \mathrm{S} \times \mathrm{R}) / \mathrm{LS}_{\mathrm{CaCO}_{3}}$ \\
\hline $\begin{array}{l}\text { Calcium oxide } \\
\text { (unreacted) (CaO) }\end{array}$ & $\left(0.56 \times \mathrm{LS}_{\mathrm{CaCO}_{3}} \times \mathrm{QLS}_{\mathrm{LS}}-\left(1.75 \times \mathrm{s} \times \mathrm{SO}_{\mathrm{x}}\right)\right.$ \\
\hline $\begin{array}{l}\left.\text { Calcium sulfate ( } \mathrm{CaSO}_{4}\right) \\
\text { Inert material (QI) }\end{array}$ & $\begin{array}{l}4.25 \times \mathrm{SO}_{\mathrm{x}} \times \mathrm{s} \\
\mathrm{Q}_{\mathrm{LS}}-\left(\mathrm{Q}_{\mathrm{LS}} \times \mathrm{LS}_{\mathrm{CaCO}}\right)\end{array}$ \\
\hline $\begin{aligned} \mathrm{S} & =\text { Input sulfur. } \\
\mathrm{R} & =\mathrm{Ca} / \mathrm{S} \text { rat1o. } \\
\mathrm{LS}_{\mathrm{CaCO}_{3}} & =\text { Percentage of } \\
\mathrm{SO}_{\mathrm{X}} & =\text { Percentage ren }\end{aligned}$ & $\begin{array}{l}\text { In the Iimestone. } \\
\text { if } \mathrm{SO}_{2} \text {. }\end{array}$ \\
\hline
\end{tabular}

Table 3.3

Total Solid Weste Distribution

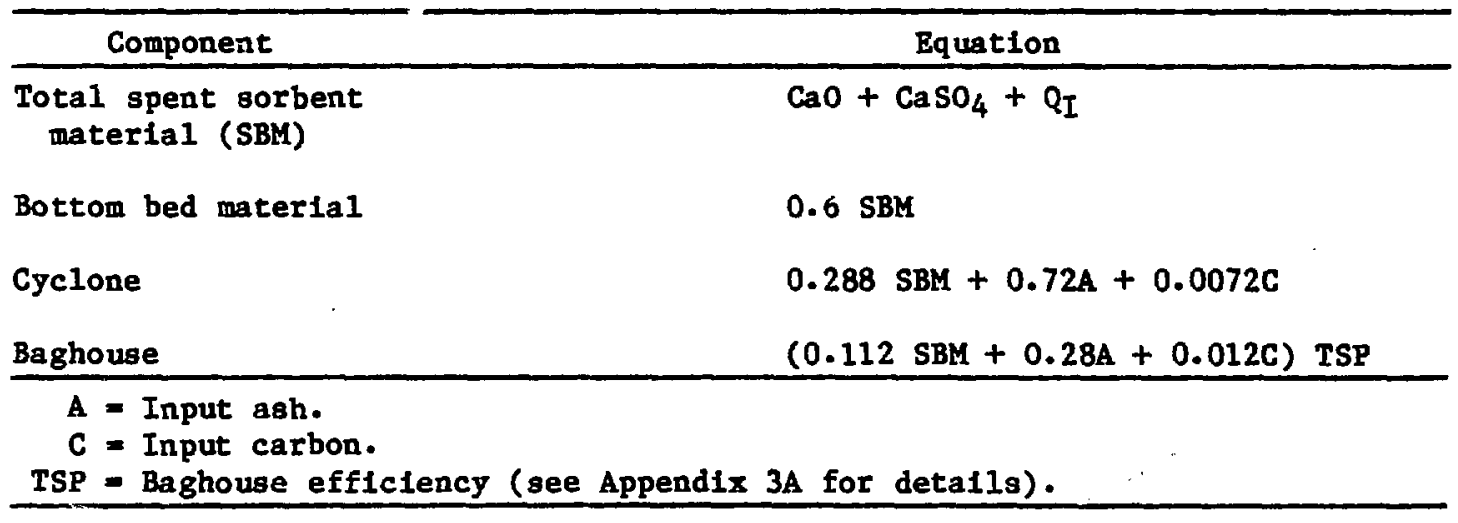

The spent sorbent material therefore consists of $\mathrm{CaSO}_{4}$, unreacted CaO, and Inert mineral impurities in the 1inestone. Table 3.2 gives the equations used to calculate these components. In addition, the solid waste contains coal ash and unburnt carbon. Table 3.3 gives the equations used to calculate the total solid waste from the bottom bed drains, the secondary cyclone, and the baghous filter. The small quantity of particulate matter in the stack gas is conputed 
by subtracting the solld waste from the three collection points from the total waste formed. A mass balance approach is then employed to distribute the elements between the bed, cyclone, baghouse, and stack gas. Table 3.4 gives the coefficients used.

The coefficients for the trace metals are at present zero. When data become available it will be a simple job to change the zeros in the data file to the new coefficlents.

For sulfur, the fraction of the input amount not captured by the limestone is assumed to be converted to $\mathrm{SO}_{2}$ and appears in the output stack gas vector under element 35. The $\mathrm{CO}_{2}$ In the stack gas (element 42) comes from both the combustion of carbon and the conversion of $\mathrm{CaCO}_{3}$ to $\mathrm{CaO}$.

The appendices give further Information on the source of the coefficlents and detalls of the computer code.

Table 3.4

Coefficients for the Distribution of Elements Between Output Streams

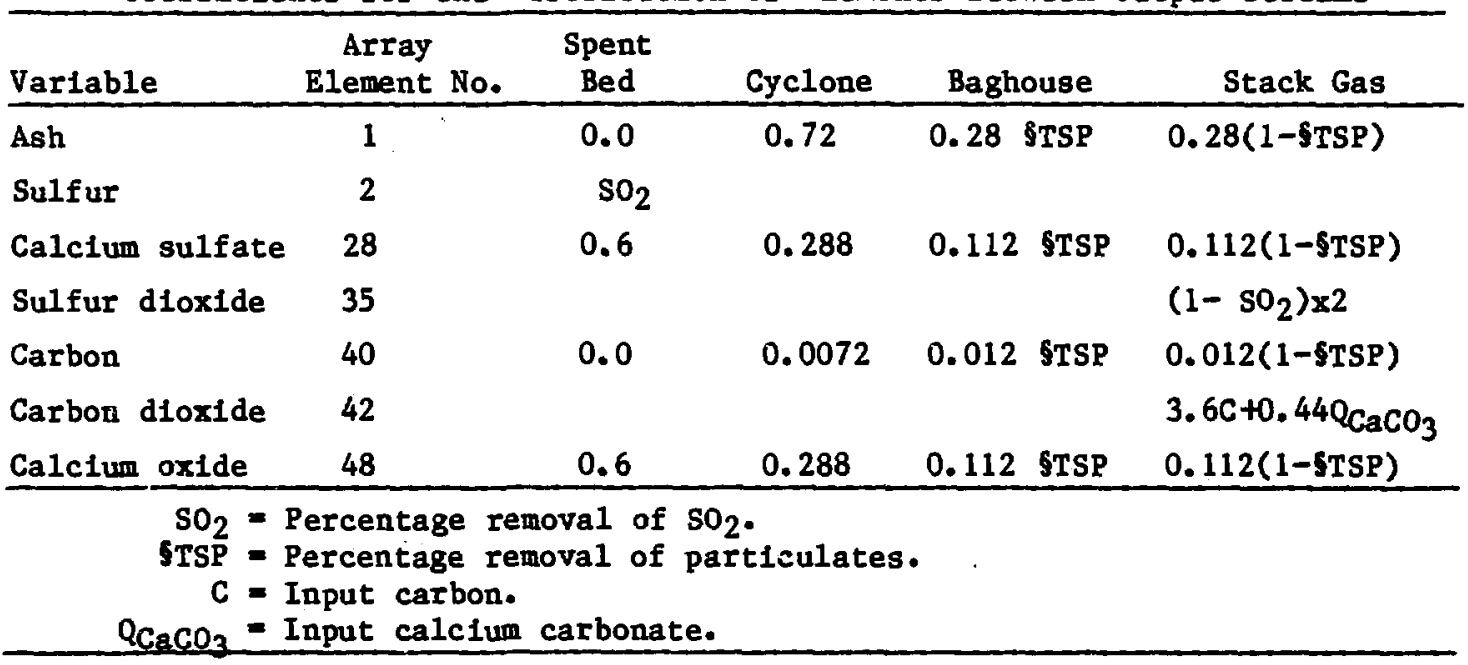




\section{REFERENCES}

1. D.N. Garner, P.S. Dzierlenga and D.N. Garner, A comparison of selected design aspects of three atmospheric fluidized bed combustion conceptual power plant designs, Proc. 5th Int. Conf: Fluidized Combust., Washington, DC, 1977.

2. D.S. Son1, Matertals-Process-Product-Model, IR\&T, McLean, VA.

3. Burns \& Roe, Inc., Conceptual Destgn of an Atmospheric Fluidized Bed Combustion Electric Power Generating Plant, Volumes 1 and III, HCP/T2455-15/1 and 3, prepared for U.S. Department of Energy, Wash1ngton, DC, 1978.

4. Babcock \& Wilcox Co., Summary Evaluation of Atmospheric Pressure Fluidized Bed Combustion Applied to Electric Utility Large Steam Generators, Volumes 1 and II, EPRI FP-308, prepared for Electric Power Research Institute, Palo Alto, CA, 1976.

5. U.S. Nationa1 Committee for Geochemistry, Trace Element Geochemistry of Coal Resource Development Related to Environmental Quality and Health, National Academy Press, Washington, DC, 1980.

6. W.M. Swlft, G.J. Vogel, and A.F. Panck, Potentlal of fluldized-bed combustion for reducing trace - element emissions, Paper 75-46-3 at the 68th Annual Meeting of the APCA, Boston, 1975.

7. R.I. Carpenter, S.H. Welssman, G.J. Newton, R.I. Hanson, E. R. Peele, M.H. Mazza, J.J. Kovach, D.A. Green, and U. Grimm, Characterizations of Aerosols Produced by an Experimental Fluidized Bed Coal Combustor Operated with Sub-Bituminous Coa1, LF-57, Inhalation Toxicology Research Institute, Lovelace Blomedical and Envirohnmental Research Institute, Albuerquerque, NM, and Morgantown Energy Research Center, Morgantown, WV, 1978. 


\section{A.1 Ca/S Molar Ratio (R)}

The equation used was developed by IR $\mu \mathrm{T}$ using data from a model developed by Babcock and Wilcox in their conceptual studies of AFB bollers ${ }^{2}$.

whera

$$
R=\frac{0.3782 \mathrm{e}^{2.147 \eta \mathrm{SO}_{\mathrm{x}}}}{\sqrt{\mathrm{H} / \mathrm{V}}}
$$

$$
\begin{aligned}
\mathrm{SO}_{\mathrm{X}} & =\text { removal percentage for } \mathrm{SO}_{2}, \\
\mathrm{H} & =\text { bed helght }(\mathrm{ft}), \\
\mathrm{V} & =\text { superflclal veloclty }(\mathrm{ft} / \mathrm{sec})
\end{aligned}
$$

3A.2 Amount of Limestone Required

$$
\text { Input ton atoms of sulfur }=\frac{S}{M W \text { sulfur }} \text {, }
$$

where

$$
S \text { = input quantity of sulfur. }
$$

MW = molecular weight.

$$
\text { Moles } \mathrm{CaCO}_{3} \text { required }=\frac{\mathrm{S} \times \mathrm{R}}{\text { MW sulfur }} \text {. }
$$

$$
\text { Quantity of } \begin{aligned}
\mathrm{CaCO}_{3} \text {. required } & =\frac{\mathrm{S} \times \mathrm{R} \times \mathrm{MN} \mathrm{CaCO}}{3 \mathrm{Sulfur}} \text { tons. } \\
& =\frac{\mathrm{S} \times \mathrm{R} \times 100}{32}=3.125 \times \mathrm{R} \times \mathrm{S} \text { tons. }
\end{aligned}
$$

Quantity of linestone required (QIS)

where

$$
Q_{\text {LS }}=\frac{3.125 \times S \times R}{L_{\mathrm{CaCO}_{3}}} \text { tons, }
$$

$$
\begin{gathered}
\mathrm{LS}_{\mathrm{CaCO}_{3}}=\text { the fraction of the limestone which is } \\
\text { composed of } \mathrm{CaCO}_{3} \text {. }
\end{gathered}
$$


3A.3 Spent Sorbent Material

$\mathrm{CaCO}_{3}$ reacts with $\mathrm{SO}_{2}$ according to the following equations:

$\mathrm{CaCO}_{3} \longrightarrow \mathrm{CaO}+\mathrm{CO}_{2}$

$\mathrm{CaO}+\mathrm{SO}_{2}+\frac{1}{2} \mathrm{O}_{2} \longrightarrow \mathrm{CaSO}_{4}$

The spent sorbent material is composed of unreacted $\mathrm{CaO}, \mathrm{CaSO}_{4}$ and Inert mineral matter in the limestone.

Calcium Oxide Formed $\left(\mathrm{CaO}_{\mathrm{f}}\right)$

$$
\begin{aligned}
\mathrm{CaO}_{\mathrm{f}} & =\mathrm{QCaCO}_{3} \times \frac{\mathrm{MHCaO}}{\mathrm{MWCaCO}} 3 \\
& =Q_{\mathrm{CaCO}_{3}} \times \frac{56}{100}=0.56 \mathrm{QCaCO}_{3} .
\end{aligned}
$$

Calcium Oxide Consumed During Reaction With $\mathrm{SO}_{2}\left(\mathrm{CaO}_{\mathrm{c}}\right)$

$$
\begin{aligned}
\mathrm{CaO}_{c} & =\frac{\mathrm{MW} \mathrm{CaO}}{M W \text { sulfur }} \times \mathrm{S} \times \mathrm{SO} \cdot \\
& =\frac{56}{32} \times \mathrm{S} \times \quad \mathrm{SO}_{\mathrm{x}}=1.75 \times \quad \mathrm{SO}_{\mathrm{x}} .
\end{aligned}
$$

Unreacted Calcium Oxide ( $\left.\mathrm{CaO}_{\mathrm{UR}}\right)$

$$
\mathrm{CaO}_{\mathrm{UR}}=\left(0.56 \mathrm{QCaCO}_{3}\right)-\left(\begin{array}{lll}
1.75 \times \mathrm{S} \times & \mathrm{sO}_{\mathrm{x}}
\end{array}\right) .
$$

Calcium Sulfate Formed $\left(\mathrm{CaSO}_{4}\right)$

$$
\begin{aligned}
\mathrm{CaSO}_{4} & =\frac{\mathrm{MW} \mathrm{CaSO}_{4}}{\mathrm{CaO}} \times \mathrm{CaO}_{\mathrm{c}} \text { tons. } \\
& =\frac{136}{56} \times 1.75 \times \mathrm{S} \times \quad \mathrm{SO}_{\mathrm{x}} \\
& =4.25 \times \mathrm{S} \times \quad \mathrm{SO}_{\mathrm{x}} .
\end{aligned}
$$


Inert Mineral Matter $\left(Q_{I}\right)$

$$
Q_{I}=Q_{L S}-\left(Q_{L S} \times \mathrm{LS}_{\mathrm{CaCO}_{3}}\right) \text {. }
$$

Total Spent Sorbent (SS)

$$
\mathrm{SS}=\mathrm{CaO}_{\mathrm{UR}}+\mathrm{CaSO}_{4}+\mathrm{Q}_{\mathrm{I}} \text {. }
$$

\section{$3 A .4$ Bottom Bed Solid Waste}

The module assumes that the bottom bed solid waste consists of $60 \%$ of the spent sorbent material 1,3 .

Total Solld Waste $=0.60 \times$ SS tons.

BB CaO (element 47) $=0.6 \times$ CaOUR tons.

BB $\mathrm{CaSO}_{4}$ (element 28) $=0.60 \times \mathrm{CaSO}_{4}$ tons.

\section{A.5 Solid Waste from Secondary Cyclone}

The module assumes the following elutriation rates ${ }^{3}$ :

$40 \%$ of the spent sorbent material,

$100 \%$ of the input ash,

$10 \%$ of the input carbon.

This waste is collected in the primary cyclone where $90 \%$ is captured, the remaining $10 \%$ going to the baghouse. The captured materlal goes to the CBC. Here $90 \%$ of the carbon is consumed, the remalning $10 \%$ and all the input ash and spent sorbent aterial going to the secondary cyclone. $80 \%$ of the material Into the secondary cyclone ts captured and appears as solid waste, the remaining 207 goes to.the baghouse.

\section{Spent Sorbent}

$$
\begin{aligned}
\text { Total Spent Sorbent }\left(C_{S S}\right) & =0.4 \times \text { SS } \times 0.9 \times 0.8, \\
& =0.288 \mathrm{ss},
\end{aligned}
$$


Likewlse

$$
\begin{aligned}
\mathrm{C}_{\mathrm{CaO}} & =0.288 \mathrm{CaO}_{\mathrm{UR}}, \\
\mathrm{C}_{\mathrm{CaSO}_{4}} & =0.288 \mathrm{CaSO}_{4} .
\end{aligned}
$$

Ash

where

$$
\begin{aligned}
C_{\text {ASH }} & =\text { ASH } \times 0.9 \times 0.8 \text { tons, } \\
& =0.72 \text { ASH, }
\end{aligned}
$$

ASH = total input ash.

Carbon

Carbon into $\mathrm{CBC}=0.1 \mathrm{C} \times 0.9$ tons. If $90 \%$ of carbon is consumed in the $\mathrm{CBC}, 10 \%$ goes to secondary cyclone.

$$
\begin{aligned}
C_{\text {Carbon }} & =0.1 \mathrm{C} \times 0.9 \times 0.1 \times 0.8, \\
& =0.0072 \mathrm{C} .
\end{aligned}
$$

where

$$
C=\text { total Input carbon to AFB. }
$$

Total Cyclone Solid Waste

$$
\begin{aligned}
c_{\text {SW }} & =c_{\text {SS }}+c_{\text {ASH }}+c_{\text {Carbon, }} \\
& =0.288 \text { SS }+0.72 \text { ASH }+0.0072 C \text { tons. }
\end{aligned}
$$

3A.6 Solld Waste from Baghouse

Total Loading for Baghouse

Spent Sorbent. The Input to the baghouse is the quantity elutriated from the main bed less that captured in the secondary cyclone.

$$
\begin{aligned}
I_{S S} & =0.4 S S-0.288 S S \\
& =0.112 \mathrm{SS} .
\end{aligned}
$$


Ash. Again the Input is the amount elutrlated from the main bed less that captured in the secondary cyclone.

$$
\begin{aligned}
I_{\text {ASH }} & =\text { ASH }-0.72 \mathrm{ASH} \\
& =0.28 \mathrm{ASH} .
\end{aligned}
$$

Carbon. The Input carbon to the baghouse is the carbon elutriated from the main bed less that captured In the cyclone, less that consumed in the CBC.

$$
\begin{aligned}
I_{\text {Carbon }} & =0.1 \mathrm{C}-0.0072 \mathrm{C}-0.081 \mathrm{C}, \\
& =0.012 \mathrm{C} .
\end{aligned}
$$

Total Solid Waste into Baghouse

$$
{ }^{I B} \text { SW }=0.122 S S+0.28 A S B+0.012 C \text {. }
$$

Allowable Emissions from Baghouse. The allowable particuiate emissions from the AFB bollers (TSP) are given as an input in terms of tons particulates/1012 Btu Input. Also given as elenent 41 of the Input coal characteristic vector is the total Btu value of the coal (B). From this, the total allowable emissions (ETSP) for the input quantity of coal can be calculated:

$$
\mathrm{E}_{\mathrm{TSP}}=\frac{\mathrm{TSP} \times \mathrm{H}}{10^{12}} \text {. }
$$

The efficlency of the baghouse required to produce the allowable entssions can be calculated as follows:

$$
\delta T S P=\frac{I B_{S W}-E_{T S P}}{I B_{S W}} .
$$

Solid Waste from Baghouse. This is given simply as the input to the baghouse multiplied by the efflclency of the baghouse. 


$$
\begin{aligned}
& \mathrm{B}_{\mathrm{SW}}=\mathrm{IB}_{\mathrm{SW}} \times \delta \mathrm{TSP}, \\
& \mathrm{B}_{\mathrm{CaO}}=0.112 \mathrm{CaO}_{\mathrm{UR}} \times \delta \mathrm{TSP}, \\
& \mathrm{B}_{\mathrm{CaSO}_{4}}=0.112 \mathrm{CaSO}_{4} \times \delta \mathrm{TSP}, \\
& \mathrm{B}_{\mathrm{ASH}}=0.28 \mathrm{ASH} \times \delta \mathrm{TSP} \text { tons, } \\
& \mathrm{B}_{\mathrm{Carbon}}=0.012 \mathrm{C} \times \delta \mathrm{TSP} \text { tons. }
\end{aligned}
$$

\section{A.7 Carbon Dioxide Produced}

$\mathrm{CO}_{2}$ from Carbon Combustion. Carbon is combusted to form $\mathrm{CO}_{2}$ In the main bed and CBC. The module assumes $90 \%$ combustion in the main bed. The remaining $10 \%$ goes to the primary cyclone where $90 \%$ is captured and sent to the $\mathrm{CBC}$, where a further $90 \%$ is combusted ${ }^{3}$.

$$
\begin{aligned}
\mathrm{C}_{\mathrm{CO}_{2}} & =\frac{\mathrm{MW} \mathrm{CO}}{\mathrm{MW} \text { carbon }}(0.9 \mathrm{C}+(0.1 \mathrm{C} \times 0.9 \times 0.9)), \\
& =\frac{44}{12}(0.9 \mathrm{C}+0.081 \mathrm{C}), \\
& =3.6 \mathrm{C} \text { tons. }
\end{aligned}
$$

$\mathrm{CO}_{2}$ from Limestone. When limestone reacts with $\mathrm{SO}_{2}, \mathrm{CO}_{2}$ is formed (see equations in Section 3A.3):

$$
\begin{aligned}
\mathrm{LS}_{\mathrm{CO}_{2}} & =\mathrm{QCaCO}_{3} \times \frac{\mathrm{MW} \mathrm{CO}}{\mathrm{MW} \mathrm{CaCO}}, \\
& =\mathrm{QCaCO}_{3} \times \frac{44}{100}=0.44 \mathrm{QCaCO}_{3} .
\end{aligned}
$$

Total $\mathrm{CO}_{2}$ Produced

$$
\mathrm{CO}_{2}=3.60 \mathrm{C}+0.44 \mathrm{QCaCO}_{3}{ }^{\circ}
$$


$3 \mathrm{~A} .8 \mathrm{SO}_{2}$ Produced

Captured sulfur (CS) $=S \times \delta \mathrm{SO}_{2}$.

$$
\begin{aligned}
\mathrm{SO}_{2} & =(\mathrm{S}-\mathrm{CS}) \times \frac{\mathrm{MW} \mathrm{SO}_{2}}{\mathrm{MW} \mathrm{sulfur}} \\
& =\left(\mathrm{S}-\left(\mathrm{S} \times \delta \mathrm{SO}_{2}\right) \times \frac{64}{32}\right. \\
& =2 \mathrm{~S}\left(1-\delta \mathrm{SO}_{2}\right) \text { tons. }
\end{aligned}
$$


APPENDIX 3B

DESCRIPTION OF COMPUTER MODULE

The AFBC solid waste module consists of one subroutine and a data file containing the fraction of the input components that are removed to the different output streams. The module is set in motion by a call to AFBC:

CALL AFBC (Q, COAL, LIMEST, BED, CYCL, BAG, STACK, SO2EFF, BEDHT, BEDV, TSPEM),

where

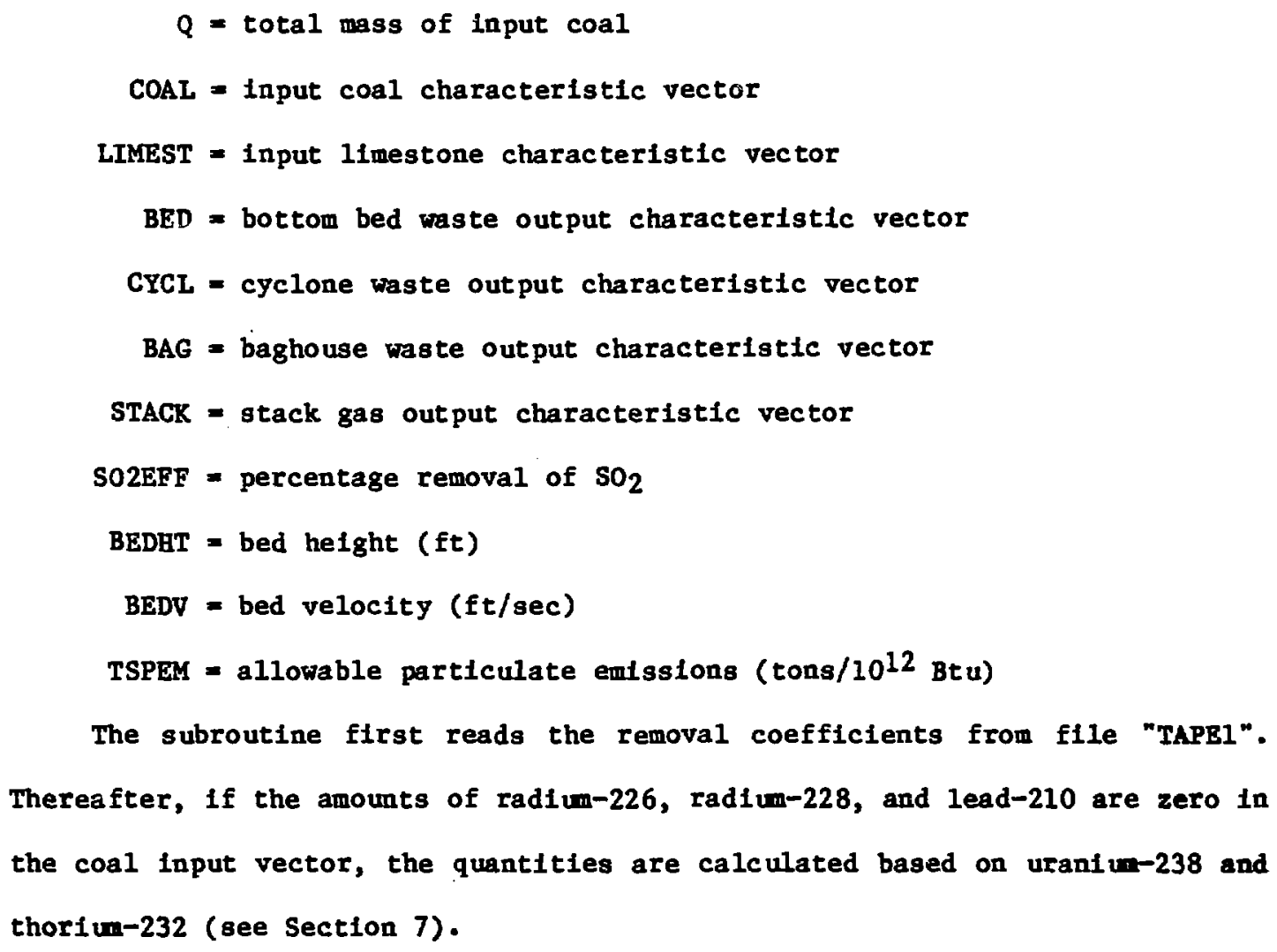
the coal input vector, the quantities are calculated based on uranim-238 and thoriun-232 (see Section 7).

The total amount of limestone (QLS) required in the AFB process is then computed as a function of the $\mathrm{Ca} / \mathrm{S}$ ratio (CASRAT), sulfur renoval efficiency 
(SO2EFF), the bed height and velocity (BEDHT, BEDV), and the amount of sulfur In the Input coal (see Appendix 3A). From this amount the total spent bed material (SBM) is calculated from its estimated components: calcium oxide (CAO), calcium sulfate (CASO4) and total Inert materials (QI). The amounts of the Individual components are then calculated by nultiplying QLS by the fraction of each of the components of the Input limestone (the original entries of the input limestone vector). These quantities replace the fractions in the 1imestone vector. (As before, if the radium and lead entries are zero, they are calculated as in Section 7.)

The total amounts of solld waste from the bed, cyclone and baghouse are then calculated as described in Appendix 3A.

A "DO" loop then multiplies the removal coefficlents by the input coal vector to obtain the amount of each component which is contained in each of the solid waste output vectors. As mentioned previously, there are presently no data for trace metal removal, and consequently all coefficients for these are zero.

Speclal Calculations Not Performed in "Do" Loop 1. Total solid waste (output array elenent 25 (AE25)) for each of the vectors was calculated previously and is therefore bypassed in the "DO" loop. 2. Certain elements are affected by the TSP removal efficlency (NTSP) which is calculated in the program to estimate total solid waste from the baghouse. These elements must be multiplied by NTSP (or 1-NTSP) after having been multiplied by the removal coefficients. These elements are ash (AE1), carbon (AE40), and calcium sulfate and oxide (AE28 and AE47 - see below). 
3. The amount of sulfur in the bottom bed waste 1 s a function of the $\mathrm{SO}_{2}$ efficiency. This is calculated by multiplying input sulfur by SO2EFF. 4. The output quantities of calcium sulfate and calcium oxide are a function of the amounts of each, respectively, that are in the input 1imestone. The output quantities are calculated by multiplying the respective removal rates by $\mathrm{CASO}_{4}$ and $\mathrm{CAO}$. The amounts removed by the baghouse, which are a function of NTSP, are calculated accordingly (see 2, above).

5. The amount of carbon dioxide ( $A E 42$ ) which goes up the stack is a function of the input carbon in the coal and the calcium carbonate in the limestone, and 18 calculated as discussed in Appendix $3 A$. 


\section{APPENDIX 3C \\ COMPUTER CODE AND SAMPLE OUTPUT}

This section gives the computer code used for the AFBC module and the data file of coefficlents, with a sample lnput and the resulting output. Tables 3C.1 and 3C.2 give the coal and limestone characteristics used as input. The other Input varlables are as follows:

$$
\begin{aligned}
\text { Quantity of coal }(Q) & =100,000.0 \text { tons. } \\
\mathrm{SO}_{2} \text { removal }(\mathrm{SO} 2 \mathrm{EFF}) & =85.0 \% \\
\text { Bed helght }(\mathrm{BEDHT}) & =3 \mathrm{ft} . \\
\text { Bed velocity }(B E D V) & =12 \mathrm{ft} / \mathrm{sec}
\end{aligned}
$$$$
\text { Particulate emissions (TSPEM) }=15 \text { tons/1012 Btu input. }
$$

The main program of the code is used only to set the input vartables. 
Table 3C.1

Input Coal Characteristics

\begin{tabular}{lclc}
\hline Element & Input Quantity (tons) & Element & Input Quantity (tons) \\
\hline Ash & 9200.0 & Manganese & 20.0 \\
Sulfur & 2500.0 & Mercury & 0.014 \\
Antimony & 0.08 & Nlckel & 1.5 \\
Arsenic & 1.1 & Selentum & 0.35 \\
Beryli1um & 0.2 & Silver & 0.02 \\
Cadmium & 0.03 & Thallium & 0.02 \\
Chromi um & 1.5 & Zinc & 1.28 \\
Copper & 1.6 & Uranium & 0.1 \\
Iron & 1000.0 & Thorium & 0.28 \\
Lead & 1.09 & Pyritic sulfur & 1870.0 \\
Magnesium & 52.0 & Carbon & 64100.0 \\
& & Btu & $2.3 \times 1012$ \\
\hline
\end{tabular}

Table 3C. 2

Input Limestone Characteristics

\begin{tabular}{lclc}
\hline Element & Fractional Composition & Element & Fractional Composition \\
\hline Ash & 0.0 & Magnesium & 0.01 \\
Sulfur & 0.0 & Manganese & $60.0 \times 10^{-6}$ \\
Antimony & $0.3 \times 10^{-6}$ & Mercury & 0.0 \\
Arsenic & $6.0 \times 10^{-6}$ & Nlckel & $6.0 \times 10^{-6}$ \\
Beryllium & $2.0 \times 10^{-6}$ & Selentum & $3.0 \times 10^{-6}$ \\
Cadmium & $0.3 \times 10^{-6}$ & Silver & $0.1 \times 10^{-6}$ \\
Chromi um & $20.0 \times 10^{-6}$ & Thallium & $0.1 \times 10^{-6}$ \\
Copper & $2.0 \times 10^{-6}$ & Zinc & $30.0 \times 10^{-6}$ \\
Iron & $1.0 \times 10^{-3}$ & Uranium & $2.7 \times 10^{-6}$ \\
Lead & $3.0 \times 10^{-6}$ & Thorium & $3.4 \times 10^{-6}$ \\
& & Calcium carbonate & 0.90 \\
\hline
\end{tabular}


PROGRAM FLUIDIOUTPUT , TAPEI . TAPEC=OUTPUT )

DIMENSION COAL $(50)$, BED (50), CYCL $(50)$, BAG $(50), 5 T A C K(50)$

REAL L IMEST ( 50 )

$0=100000.00$

SOZEFF $=85$.

BEDHT $=3$.

$B E D V=12$.

TSPEM $=15$.

$\operatorname{COAL}(1)=9200$.

$\operatorname{COAL}(2)=2500$.

$\operatorname{COAL}(3)=0.08$

$\operatorname{COAL}(4)=1.1$

$\operatorname{COAL}(5)=0.2$

$\operatorname{COAL}(6)=0.03$

$\operatorname{COAL}(7)=1.5$

$\operatorname{COAL}(8)=1.6$

$\operatorname{COAL}(9)=1000.0$

COAL $(10)=1.09$

COAL $(11)=52.0$

$\operatorname{COAL}(12)=20.0$

$\operatorname{COAL}(13)=0.014$

$\operatorname{COAL}(14)=1.5$

$\operatorname{COAL}(15)=0.35$

$\operatorname{COAL}(16)=0.02$

COAL $(17)=0.02$

$\operatorname{COAL}(18)=1.28$

$\operatorname{COAL}(19)=0.1$

$\operatorname{COAL}(20)=0.28$

DO $10 \quad I=21.38$

10 CONTINUE

COAL (I) $=0$.

COAL $(39)=1870$

$\operatorname{COAL}(40)=64100$

COAL $(41)=2$. 3E I 2

DO $20 \quad I=42,50$

20 CONTINUE

$\operatorname{COAL}(J)=0$.

LIMEST $(1)=0$.

LIMEST $(2)=0$.

LIMEST $(3)=0.3 E-6$

LIMEST $(4)=6 . E-5$

LIMEST $(5)=2$. E-S

LIMEST $(6)=.3 E-6$

LIMEST $(7)=20 . E-6$

LIMEST $(8)=2 . E-6$

$\operatorname{LIMEST}(9)=1 . E-3$

LIMEST $(10)=3 . E-6$

LIMEST $(11)=0.01$

L IMEST $(1$ ( $)=60 . E-6$

LIMEST $(13)=0.0$

LIMEST $(14)=6 . E-6$ 


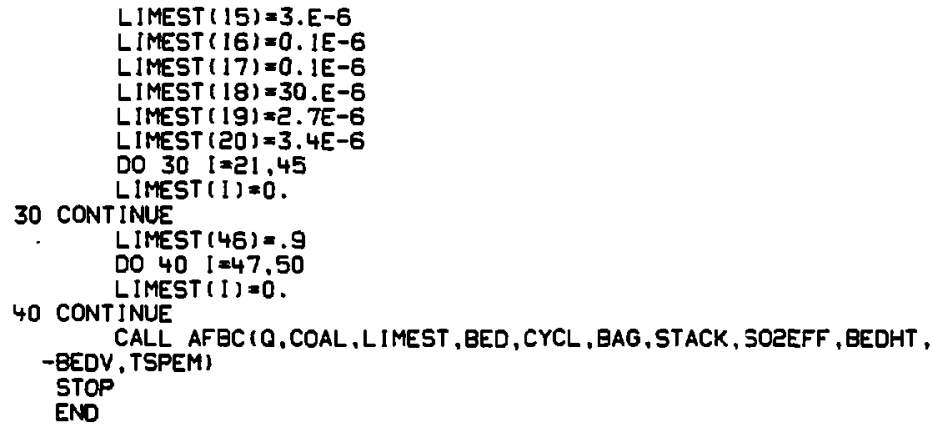

SUBROUT INE AFBC $Q$ Q, COAL, LIMEST, BED, CYCL, BAG, STACK, SOZEFF, BEDHT, -BEDV. TSPEMI

DIMENSION COAL (50), BED (50), CYCL (50), BAG(50), STACK (50),

-BEDC (50), CYCLC (50), BAGC (50), STACKC (50)

REAL LIMEST (50), NTSP, IBSW

C * Removal coefFic ients read in from data fille *

REAO $(1,1000)(B E D C(1), C Y C L C(1), B A G C(1), \operatorname{STACKC}(1), I=1,50)$

C CALCULATION OF RA-226,RA-228 \&PB-210 IN COAL IF NOT GIVEN AS INPUT

IF (COAL (2I) .EQ. 0.) COAL (2I) $=3.38 E-7 * \operatorname{COAL}(19)$

IF (COAL (22) .EQ. 0. ICOAL $(22)=4.01 E-10 \cdot \operatorname{COAL}(20)$

IF (COAL (23) EO. 0. ICOAL (23) $=4.37 E-9 \cdot \operatorname{COAL}(19)$

1000 FORMAT $(4 F) 10.5)$

SOZEFF $=$ SOEEFF $/ 100$

C - CALCULATION OF CA/S MOLAR RATIO

CASRAT $\approx .3782$ *EXP (2.14*SO2EFF) / SORT (BEDHT/BEDV)

C * CALCULATION OF QUANTITY OF LIMESTONE REOUIRED

QLS $=3.125 *$ COAL (2) * CASRAT / IIMEST (46)

C - CALCULATION OF CAO,CASO4 AND INERT MATERIAL IN SPENT BED MATERIaL CAO $=.56 \cdot L$ IMEST (46) *QLS- $1.75 * C O A L(2) *$ SO2EFF CASO4 $=4$. $25+C O A L(2)=$ SOEEFF OI =OAS-OLS*LL IMEST (46)

C - calculation of total spent bed material $S B M=C A O+C A S O 4+Q I$

C * QUANTITIES OF INPUT ELEMENTS IN LIMESTONE CALCULATEO DO $10 \quad 1=1,50$ LIMEST ( I ) $=$ OLS - L IMEST (I)

10 CONTINUE

C CALCULATION OF RA-226,RA-22B \& PB-210 IN LIMESTONE IF (LIMEST (2I) , EO.0.)LIMEST (2I ) =3.38E-7-LIMEST ( 19 ) IF (LIMEST (22) . EO. 0.) LLIMEST $(22)=4.0 E-10 \cdot \operatorname{LIMEST}(20)$ IF (LIMEST (23) . EQ. O. )LIMEST (23) $=4.37 E-9$ - LIMEST (19)

C CALCULATION OF TOTAL BotTOM BED MATERIAL BED (25) =. .

C - calculation of total cyclone solid haste CYCL $(25)=.288 * 58 M+.72 * C O A L(1)+.0072 * \operatorname{COAL}(40)$

C calculation of allohable tSP emissions ETSP $=$ TSPEM $=$ COAL $(4) / 1$.EI2

C - CALCULATION OF INPUT LOADING TO BAGHOUSE IBSH $=.112 * S B M+.28 * \operatorname{COAL}(1)+.012 * \operatorname{COAL}(40)$ 
C - calculation of requtred baghouse efficicency NTSP $=($ IBSW-ETSP) / IBSW

C CALCULATION OF TOTAL Baghouse SOlid WASTE

BAG $(25)=(.112 * S B M+.28 * \operatorname{COAL}(1)+.012 * \operatorname{COAL}(40)) \cdot N T S P$

C - CALCULATION OF OUANTITY OF EACH ELEMENT IN EACH WASTE STREAM DO $20 \quad I=1,50$

C - I=25 IS THE TOTAL SOLID WASTE WHICH HAS ALREADY BEEN CALCULATED IF (I .EQ. 25)GO TO 20 $\operatorname{BED}(1)=\operatorname{COAL}(1) * \operatorname{BEDC}(1)$ $C Y C L(1)=C O A L(I) \cdot C Y C L C(I)$ BAG (I) $=$ COAL ( I) BAGC (I)

STACK( [ ) =COAL ( [)*STACKC ( I)

20 CONTINUE

$\operatorname{STACK}(25)=0$.

C - CALCULATION OF AMOUNT OF TSP IN BAGHOUSE AND STACK GAS BAG (1) =BAG (1) $*$ NTSP

STACK (1) =STACK $(1) *(1$-NTSP)

C - CALCULATION OF AMOUNT OF SULFUR IN BOTTOM 8ED material BED $(2)=$ COAL $(2)$ - SOZEFF

C CALCULATION OG THE AMOUNT OF CASO4 IN EACH WASTE STREAM BED (2B) =CASO4-BEDC (2B) CYCL (2B) $=\mathrm{CASO} 4 * \mathrm{CYCLC}(29)$ $B A G(28)=C A S O 4 \cdot B A G C(2 B) * N T S P$ STACK $(28)=C A S O 4 * S T A C K C(2 B) *(1 .-N T S P)$

C *ALCULATION OF AMOUNT OF SOz IN STACK GAS STACK $(35)=$ COAL $(2)+2 *(1,-$ SOEEFF $)$

C - CALCLLATION OF AMOUNT OF CARBON IN BAGHOUSE AND STACK GAS BAG $(40)=B A G(40) * N T S P$ STACK $(40)=S T A C K(40) *(1 .-N T S P)$

C - CALCULATION OF AMOUNT OF COZ IN STACK GAS STACK $(42)=3.6 \cdot \operatorname{COAL}(40)+.44 \cdot$ L IMEST $(46)$

c calculation of amount of CAO IN EACH haste stream BED $(47)=C A O=B E D C(47)$ CYCL (47) =CAO*CYCLC (47) $B A G(47)=C A O=B A G C(47) * N T S P$ STACK $(47)=$ CAO + STACKC $(47) *(1,-N T S P)$ HRITE $(2,100)$

100 FORMAT $(1 \mathrm{H})$

WRI TE (2, 2000)0,QLS, (COAL (I),LIMEST (I),BED (I), CYCL ( I), BAG ( I). $-\operatorname{STACK}(1), I=1,4)$

2000 FORMAT ( $1 X$.TOTAL INPUT COAL: * T31,EI2.5/1X, "TOTAL LIMESTONE REQUIR -ED: *,T31, E12.5/11X, *ELEMENT *, T21, "INPUT COAL*, T36, "L IMESTONE* T51. - SPENT BED MAT. * TG6, "CYCLONE*, TBI "BAGHOUSE* TSE, *STACK* 1

$-1 X, 106(*-) / 1 X, * A S H *, T 20, E 12.5,5(3 X, E 12.5) \%$

$-1 X$, *SULFUR*,T20,E $12.5,5(3 X, E 12.5) /$

$-1 X$. ANTIMONY , T2O,EI2.5,5(3X,E12.5)

-IX. ARSENIC*, T20,E12.5,5(3X,E12.5))

WRITE (2,2001) (COAL (1),LIMEST (I),BED (1),CYCL (I),BAG (I), STACK (I), $-[=5,8]$

2001 FORMAT ( $1 X,+B E R Y L L I U M *, T 20, E 12.5 .5(3 X, E 12.5) /$

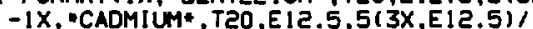

$-1 X$. "CHROMILM , T2D,E12.5.5(3X,E12.5)/

$-1 X$, "COPPER*, T20,E I2.5,5 (3X,Ele.5))

WRI TE (2,2002) (COAL (I) ,LIMEST ( I),BED (I),CYCL (I),BAG (I), STACK (I), $-[=9,12]$ 
2002 FORMAT ( $1 X, *$ IRON*,T20,E12.5,5(3X,E-12.5)/

$-1 X$, "LEAD*, T20,EI2.5,5(3X,EI2.5)/

$-1 X$. "MAGNESIUM", T20.E12.5,5(3X,E 12.5$) /$

$-1 X$. MANGANESE*,T20,E12.5,5(3X,E12.5))

WRI TE (2,2003) (COAL ( 1$), L I M E S T(1), \operatorname{BED}(1), \operatorname{CYCL}(1), \mathrm{BAG}(1), 5 T A C K(I)$, $-1=(3,16)$

2003 FORMAT ( $1 X, *$ MERCURY*,T20,EI2, 5,5(3X,EI2.5)/

$-1 X, *$ NICKEL *,T20,E12.5,5(3X,EI2.5)/

-1X. SELENIUM*,T20,E12.5,5(3X,E12.5)

$-1 X$ * *SILVER*,T20,E12.5,5(3X,E12.5)\}

WRI TE $(2,2004)(\operatorname{COAL}(i), L$ IMEST ( [)$, \operatorname{BEO}(1), \operatorname{CYCL}(1), \operatorname{BAG}([), \operatorname{STACK}(1)$, $-1=17,20)$

2004 FORMAT (1X, *THALLIUM*, T20,El2.5,5(3X,El2.5)/

$-1 X,-Z$ INC. T20.El2.5,5(3X,El2.5)/

-IX, -URANIUM-238*,T20,EI2.5,5(3X,EI2.5)/

- IX.*THORIUM-232*,T2N,EI2.5,5(3X,Ele.5)

WRI TE ( 2,2005 ) (COAL (1), L IMEST ( I), BED (I), CYCL (1), BAG ( ) , STACK (I), $-[=2 !, 23)$,

-COAL (25), L IMEST (25), BED(25), CYCL (25), BAG(25), STACK(25).

-COAL (2B), L IMEST (28), BED (28), CYCL (28),BAG(2B), STACK (28)

2005 FORMATIIX, RADIUM-2Z6*, T20.EI2.5,5(3X,EI2.5)/

$-1 X,+R A D I U M-22 B *, T 20, E 12,5,5(3 X, E I 2,5))$

$-1 X, * L E A D-210 *, T 20, E I 2.5,5(3 X, E I 2.5) /$

- IX, +TOTAL SOL ID WASTE , T20,Ei2.5,5(3X,E12.5)/

$-1 X, *$ CALCIUM SULFATE*,T20,E $12.5,5(3 x, E 12.5))$

WRI TE (2,2006) COAL (35), L IMEST ( 35 ), BED ( 35 ), CYCL (35), BAG (35), -STACK (35).

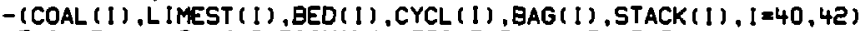

2006 FORMAT (IX, "SULFUR DIOXIOE*,T20,E12,5,5(3X,EI2.5)/

- 1 X. CAREON*,T20,E12.5,5(3X,EI2.5)

- IX, *ETU*.T20.E12.5.5(3X,E12.5)i

- IX."CARBON DIOXIDE*,T20,EI2.5,5(3X,EI2.5))

WRI TE (2,2007) (COAL (I), LIMEST (I), BED (I),CYCL (I), BAG (I), -STACK (I), I $=46.47)$

2007 FORMAT (IX, CALCIUM CARBONATE , T20,EI2.5,5(3X,EI2.5)/

- IX. •CALCIUM OXIDE*.T20,EI2.5,5(3X,EI2.5)

RETURN

END 


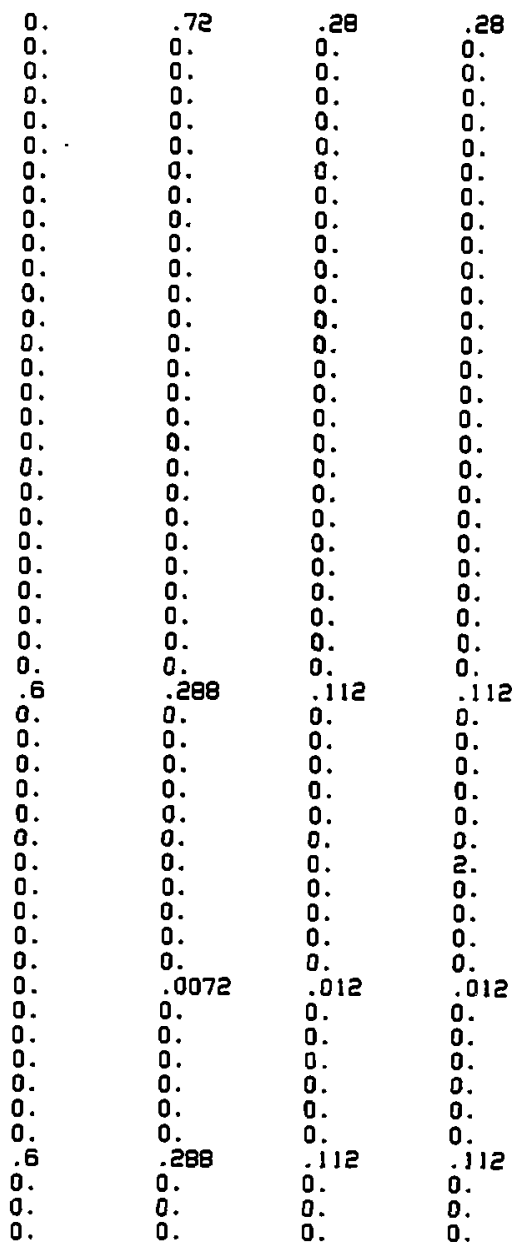




\begin{tabular}{|c|c|c|c|c|c|c|}
\hline ELEMENT & INPUT COAL & LIIAESTONE & SPENT BED MAT. & CYCLONE & BAGHOUSE & STACK \\
\hline $\begin{array}{l}\text { ASH } \\
\text { SULFUR } \\
\text { ANTIMONY } \\
\text { ARSENIC } \\
\text { EERYLLIUM } \\
\text { CADMIUM } \\
\text { CHROMIUM } \\
\text { COPPER } \\
\text { IRON } \\
\text { LEAD } \\
\text { MAGNESIUM } \\
\text { MANGANESE } \\
\text { MERCURY } \\
\text { NICKEL } \\
\text { SELENIUM } \\
\text { SILVER } \\
\text { THALLIUM } \\
\text { ZINC } \\
\text { URANIUM-23B } \\
\text { THORIUM-232 } \\
\text { RADIUM-226 } \\
\text { RADIUM-Z2B } \\
\text { LEAD-2ID } \\
\text { TOTAL SOLID WASTE } \\
\text { CALCIUM SULFATE } \\
\text { SULFUR DIOXIDE } \\
\text { CARBON } \\
\text { BTU } \\
\text { CARBON OIOXIDE } \\
\text { CALCIUM CARSONATE } \\
\text { CALCIUM OXIDE }\end{array}$ & $\begin{array}{l}.92000 E+04 \\
.25000 E+04 \\
.80000 E-01 \\
.11000 E+01 \\
.20000 E+00 \\
.30000 E-01 \\
.15000 E+01 \\
.16000 E+01 \\
.10000 E+04 \\
.10900 E+01 \\
.52000 E+02 \\
.20000 E+02 \\
.14000 E-01 \\
.15000 E+01 \\
.35000 E+00 \\
.20000 E-01 \\
.20000 E-01 \\
.12800 E+01 \\
.10000 E+00 \\
.28000 E+00 \\
.33800 E-07 \\
.11228 E-09 \\
.43700 E-09 \\
0 . \\
0 . \\
0 . \\
.64100 E+05 \\
.23000 E+13 \\
0 .\end{array}$ & $\begin{array}{l}0 . \\
0 . \\
.12145 E-01 \\
.24290 E+00 \\
.80967 E-01 \\
.12145 E-01 \\
.80967 E+00 \\
.80967 E-01 \\
.40484 E+02 \\
.12145 E+00 \\
.40484 E+03 \\
.24290 E+01 \\
0.24290 E+00 \\
.24290 E+00 \\
.12145 E+00 \\
.40484 E-02 \\
.40484 E-02 \\
.12145 E+01 \\
.10931 E+00 \\
.13764 E+00 \\
.36945 E-07 \\
.55058 E-10 \\
.47767 E-09 \\
0 . \\
0 . \\
0 . \\
0 . \\
0 . \\
0 . \\
.36435 E+05 \\
0 .\end{array}$ & $\begin{array}{l}0 . \\
.21250 E+04 \\
0 . \\
0 . \\
0 . \\
0 . \\
0 . \\
0 . \\
0 . \\
0 . \\
0 . \\
0 . \\
0 . \\
0 . \\
0 . \\
0 . \\
0 . \\
0 . \\
0 . \\
0 . \\
0 . \\
0 . \\
0 . \\
.17859 E+05 \\
.54189 E+04 \\
0 . \\
0 . \\
0 . \\
0 . \\
0 . \\
.10011 E+05\end{array}$ & $\begin{array}{l}.66240 E+04 \\
0 . \\
0 . \\
0 . \\
0 . \\
0 . \\
0 . \\
0 . \\
0 . \\
0 . \\
0 . \\
0 . \\
0 . \\
0 . \\
0 . \\
0 . \\
0 . \\
0 . \\
0 . \\
0 . \\
0 . \\
0 . \\
0 . \\
.15658 E+05 \\
0.26010 E+04 \\
0.46152 E+03 \\
0 . \\
0 . \\
0 . \\
.48053 E+04\end{array}$ & $\begin{array}{l}.25627 E+04 \\
0 . \\
0 . \\
0 . \\
0 . \\
0 . \\
0 . \\
0 . \\
0 . \\
0 . \\
0 . \\
0 . \\
0 . \\
0 . \\
0 . \\
0 . \\
0 . \\
0 . \\
0 . \\
0 . \\
0 . \\
0 . \\
0 . \\
.66443 E+04 \\
.10063 E+04 \\
0 . \\
.76523 E+03 \\
0 . \\
0 . \\
0 . \\
.18591 E+04\end{array}$ & $\begin{array}{l}.13305 E+02 \\
0 . \\
0 . \\
0 . \\
0 . \\
0 . \\
0 . \\
0 . \\
0 . \\
0 . \\
0 . \\
0 . \\
0 . \\
0 . \\
0 . \\
0 . \\
0 . \\
0 . \\
0 . \\
0 . \\
0 . \\
0 . \\
0 . \\
0 . \\
.52250 E+01 \\
.75000 E+03 \\
.39734 E+01 \\
0.24679 E+05 \\
0 . \\
.96530 E+01\end{array}$ \\
\hline
\end{tabular}




\section{SOLID WASTE MODULE FOR LURGI PROCESS COAL GASIFICATION}

\subsection{Introduction}

Increased demand for liquid and gaseous fuels, coupled with decreasing domestic supply, has led to an incressing interest in the synthetic production of fuel oils and gases from coal. The coal supplies of the U.S. are sufficiently abundant to supply the country with energy for decades. While many existing large facilities could convert directly from oll and natural gas to coal, other fuel-consuning activities, e.g., residential heating, could not change over to coal without enormous costs in modification of present equipnent and addition of pollution control devices to prevent adverse environmental effects. Production of synthetic fuels from coal would, in effect, eliminate the need to modify existing equipment. In particular, coal gasification is capable of creating a high Btu synthetic natural gas (SNG) which can be used as a direct substitute for natural gas and as such can use existing storage and transportation facilities (pipelines and rail and truck distribution systems). Low and medium Btu gas can also be produced from coal.

\subsubsection{Lurg1 Gasifiers}

Techniques for coal gasification have been in existence for many years. Modern techniques of gasification had their origin in Germany, and the first commerclal coal gasifier was bullt in Hirschfelde, Germany, in 1936. The process used in this first plant is known as the Lurgi process. While there are other types of gasifiers (e.8., Synthane, Hygas, etc.), most commerclal gasification plants are Lurgi. To date, there are eighteen foreign low and nedium Btu commercial Lurgi gasification facilities. There are five commercial low'Btu gasifiers in the U.S. that are in production or near 
completion. While there are no commerclal high Btu gasifiers in existence, there are several ongoing DOE-sponsored demonstration projects.

All solid waste estimates in this module are based on Lurgi gasifier data. While there is no reason to belleve that the solid waste streans fron all types of gasification w11 be similar in composition to that generated by the Lurgl process, use of Lurgl data as a basis for estination. is an acceptable compromise in determining the composition of solid waste for several reasons:

- very little data on solld waste are avallable for other types of gasification;

- solid waste from some other processes (e.g., ash fron the Synthane process) is not expected to be significantly different frou Lurg $1^{1}$ (although Synthane produces little or no tar and oll condensates as does Lurg1);

- since Lurgl gasifiers are already used comercially it is reasonable to assume that wany new commerclal gasifiers will also be Lurgi;

- present solid waste data for Lurgl are so variable that the "noise" from errors in the data may cover any difference between gasifier types.

While most of the basic processes described below pertain to all types of gasiflers, the discussion w11 center around the Lurgi dry ash process. Only low and high Btu gas production processes w11 be considered, although solid waste generation will be the same for all types (see Section 4.3). 


\subsection{Gasification Principles}

In general, the actual gasification of coal consists of three basic steps: coal preparation, coal gasification, and gas purification. For SNG production, there is a fourth step, gas upgrading. In addition to the actual conversion of coal to gas, the following supportive (utility and pollution contro1) processes may be required: steam and power generation, air pollution control, water treatment, and sulfur recovery. Figure 4.1 gives a flow diagram of a "typlcal" Lurgl gasifler for both low Btu gas and SNG.

\subsubsection{Coal Preparation}

Preparation. For Lurgi applications, preparation of coal is very seldom more than breaking and sizing the coal to the .32 to 3.5 -cm-dianeter size necessary for the feed stream. Except for coal with a high moisture content ( $>36 \%)$, drying and pretreatment to prevent caking are unnecessary.

Solid Waste from Coal Preparation. Solid waste from drying and pretreatment of coal is not considered here, as these processes are rarely used. Waste from breaking and sizing is considered elsewhere (Section 1) and can be estimated using the solid waste module for physical coal cleaning.

\subsubsection{Coal Gasification}

Gasification. Coal is fed in through the top of the gasifier. It passes through four zones of increasing temperature in the gasification chamber before what remains exits through the bottom as ash. The four zones are, in order of entry, drying, devolatilization, gasification, and combution. The product gas rises, counter to the coal feed, and exits near 


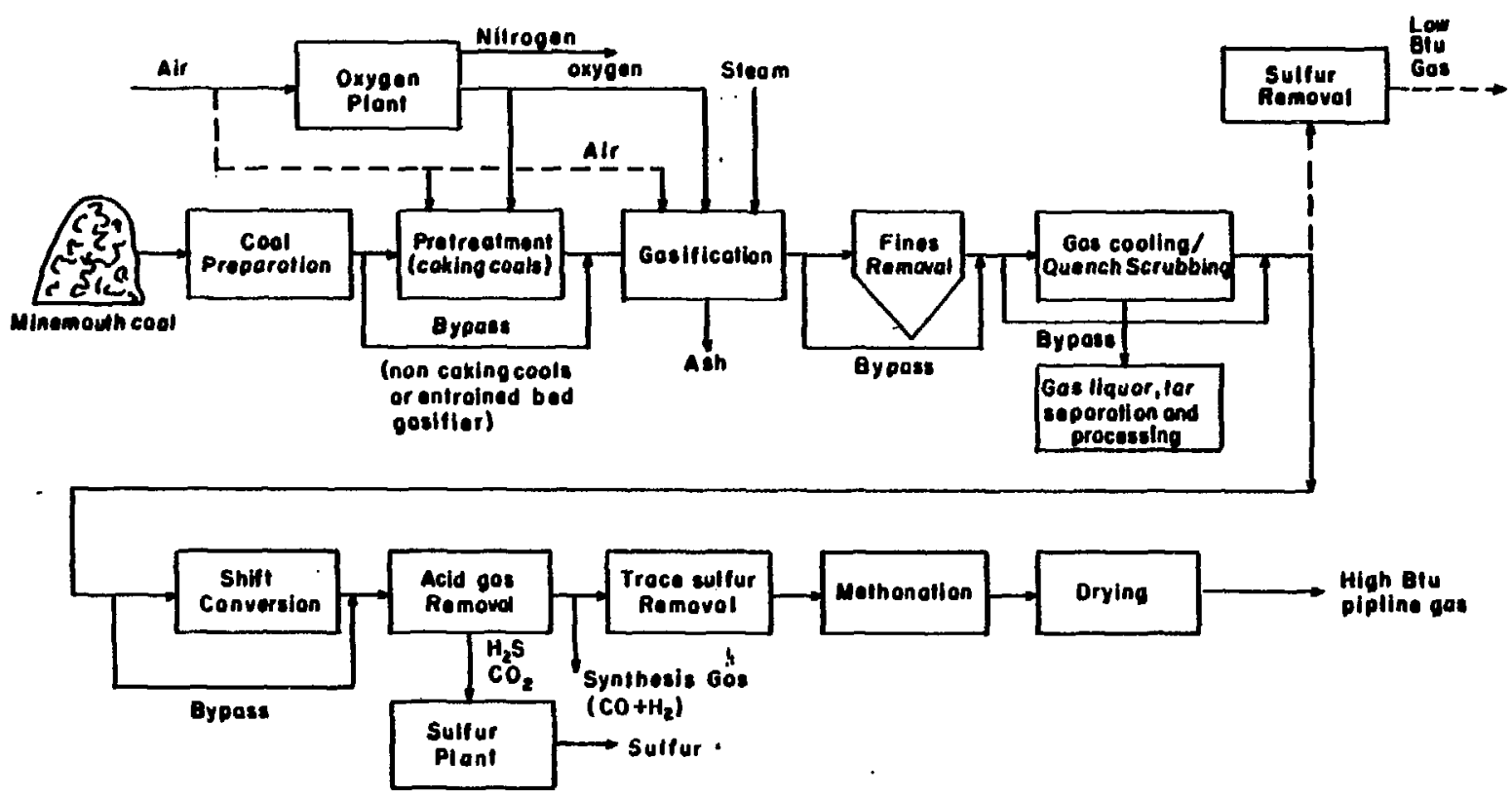

Figure 4.1 Schematic Flow Diagran of a Coal Gasiflcation Plant (From Reference 8) 
the top of the gasifler. The ash is discharged to an ash lockhopper through the bottom of the gasifier.

Solid Waste from Gasification. Solid waste from the gasification process consists of bottom ash, including some carbon, sulfur, and trace elements, along with quench water used to facilitate handling of the hot ash.

It is recognized that most of the ash and nonvolatile trace elements in the Input coal are captured in the botton ash. Highly volatile trace components (e.g., mercury, selentum, and arsentc) escape in large part with the raw product gas 2,3 .

\subsubsection{Gas Purification}

\section{Gas Purification Processes}

Gas Cooling. Cooling the product gas after it leaves the gasification chamber results in the removal of condensable components of the raw gas and temperature reduction of the gas for further processing (In the case of SNG production). The gas is first put through a primary cooler. For production of SNG, some of this cooled gas is sent to shift reaction (see Section 4.2.4) and all of the gas is put through a secondary cooling process. As the gas cools, moisture, tars, olls, and other components of the raw gas condense and are channeled into a gas liquor strean.

Acid Gas Removal (SNG Production). For SNG production, the cooled gas must be purifled of hydrogen sulfide and sulfur trace compounds. Carbon dioxide must also be removed to increase the heating value of the product gas. Lurgi systems use the Rectisol process to remove acid gas. This process Is based on the absorption of $\mathrm{CO}_{2}, \mathrm{H}_{2} \mathrm{~S}$, and other compounds in cold methanol. 
The acid gas is then usuliy sent through a sulfur recovery process to produce marketable sulfur.

Methanation Guards (SNG Prodiction). Further removal of trace sulfur compounds is sometimes necessary to prevent contamination of the methanation catalyst (see Section 4.2.4). Methanation guards are flxed beds of adsorbents over which the product gas passes after acid gas removal. The methanation guard beds are generally of four types:

1) metal (zinc, Iron or nickel) oxide

2) metal oxide - impregnated activated carbon

3) activated carbon

4) molecular sleve

Solld Waste from Gas Purification

Solid waste from gas purification falls into three basic categorles: gas liquor (Including separated tar and oll), recovered sulfur, and spent catalyst.

Gas Liquor from Cooling. After primary and secondary cooling, the resulting gas liquor streams are sent through tar/oll separation processes. The three output solid waste streams from these processes (separated gas 11quor, tar, and o11) w11l contain virtually all of the remaining inorganic trace elements (except for some of the more volatile elements - see section 4.3). They will also contain some of the noncombusted cirbon and sulfur.

Solid Waste from Acld Gas Removal. Solld waste from the removal of acid gas will result only from the sulfur recovery process. 
Catalysts fron Methanation Guard. The methanation guard contributes to solid waste generally only in spent sorbent material. The periodicity of purging or removal of the sorbent material is not yet completely known, although time estimates of catalyst removal are from 6 months to two years 4 . Trace elenent constituents of the material contributed by the product gas are believed to be small enough to be disregarded. Constituents of the sorbent material itself may contribute significant concentrations of trace elements to solid waste.

\subsubsection{Gas Upgrading (SNG Production). Gas upgrading consists of shift} conversion of some of the (primary) cooled gas before secondary cooling, and methanation and drying of the product gas after acid gas and trace sulfur removal.

\section{Gas Upgrading Processes}

Shift Conversion. While a large part of the methane is produced in the gasification chamber, conversion of product gas to SNG which is pipeline quality requires conversion of hydrogen and carbon monoxide to methane. This In turn requires that, prior to methanation (see below), the raw gas have a 3:1 $\mathrm{H}_{2} / \mathrm{CO}$ ratio. After prinary cooling of the gasifier exit gas, some of the cooled gas (usually about 50\%) is sent to shift conversion to achieve this rat1o. The shift converter is usually a cobalt molybdate-based catalyst through which the gas flows.

Methanation and Drying. Methanation and drying ere the final steps in producing SNG. Methanation is the catalytic reaction of carbon oxides and lygdrogen to form methane and water. A nickel-based catalyst is usually used. 
Drying is accomplished by condensation (for removal of most of the noisture created in methanation) and sorption (for residual moisture removal).

\section{Solid Wastes from Gas Upgrading}

Solid wastes from gas upgrading consist of the spent catalysts Involved. Although data are 11mited, contributions of trace elements from the gas are thought to be negligible, since almost all trace elements are removed In gasifler bottom ash and gas liquor streams (see Sections 4.2.2 and 4.2.3). Contributions from the spent catalyste may be significant, although catalyst Iife for the methanation process is estimated to be 2 to 5 years 1 .

4.2.5 Supportive Processes in Coal Gasificetion. Supportive processes to the gasification of coal include steam and power generation, air pollution control, water treatment, and sulfur recovery.

\section{Supportive Processes}

Steam and Power Generation. Most gasification facilities w11 have on-site plants for generating the steam and power needed for gasification. Fuels for this factlity can include gas, oil, coai, and gasification by-products.

Alr Pollution Control. Alr pollution control devices, for control of emissions from gasification and supportive processes, w11 generally be similar to those found in conventional utility boilers, such as electrostatic precipitators and FGD systems.

Water Treatment. Water treatment processes include treatment of separated gas liquor and ash quench water. 
Sulfur Recovery. Marketable sulfur can be recovered from removed acid gas.

Solid Waste from Supportive Processes

Solid waste from supportive processes generally consists only of ash from power generation, ash and sludge from air pollution control, and recovered sulfur. Westes from power generation and alr pollution control devices have been described elsewhere (Section 2); the recovered sulfur can be assumed to be almost pure (although some trace compounds may exist ${ }^{5}$ ) and can be marketed, even though here it is characterized as a waste product.

\subsection{Modeling Ass umptions}

As mentioned before, data on solid waste, especlally the trace constituents of that waste, are few and variable. Most data relate to Lurg1 gasifiers and as such this module assumes the shape of a "typlcal" Lurg1 gasifier.

Almost all data on gasifier wastes are limited to four waste streams: bottom ash, oil, tar, and separated gas 1iquor. No data were found on any trace elements in either recovered sulfur or spent catalysts. Since it is recognized that virtually all inorganic trace metals, ash, and noncombusted free carbon have been removed from the coal and gas by the gasification and cooling steps, it was decided to assume that all trace elements (except mercury and selentum) were found in these waste streams. Some mercury and most of the selenium are unsccounted for and are assumed to have been lost in fugltive gas emissions. Recovered sulfur is assumed to be pure sulfur with no trace contamination. 
Since catalysts involved in the gasification procedures are renoved or purged intermittently and their constituency is unknown, it was decided to disregard them as components of solid waste. This decision is also warranted by the fact that wany of the catalyats can be recycled ${ }^{\text {. Inclusion of theae }}$ In the module when and if data become avallable would be a simple task.

Solid wastes from coal preparation, power generation, and air pollution control have been characterized In other solid waste modules (Sections 1, 2); these wastes can be estimated, if necessary, by the appropriate solid waste module (or subroutine).

Because of the varlability of the data, it was impossible to obtain estimates of trace element removal rates which would be a function of some characteristic of the Input coal (such as trace element content). Therefore each process was assumed to remove a fixed percentage of the total mass of the Input coal content of an element, for each element. These percentages are given in the next section.

The Lurgi process can produce low, mediun, or high Btu product gas, the only differences being more gas purification and upgrading steps as one Increases the Btu content. Production of all grades of gas include the gasification and cooling steps; since these are the only steps assumed to produce solid waste, solid wastes for all gas grades can be characterized by the module.

4.4. Cosi Gasification Kodule Description 


\subsubsection{Seneral Description}

The gasification module assumes constant removal rates for each of the input elements in each of the processes which are assumed to generate all of the solid waste. The module is called with the following arguments:

- total mass of coal

- Input coal characteristics vector

o output solid waste characteristics vectors

The input and output vectors each contain 50 elements. These elements are shown in Table 4.1. Since these vectors are constructed to be conformable to any of the solid waste modules which have been produced, there are presently some empty elements ( 48 to 50 , not shown in Table 4.1) and some elements which are not applicable to this module, and as such are disregarded (set to 0) in the output vectors and ouitted in the output printout.

Table 4.2 gives the coefficients which determine the amount of each element that goes to each solid waste stream. Note that most of the elements' coefficients sum to 1 , reflecting the assumption of total removal in these streams. Table 4.3 gives the calculation of water and total waste for each stream. It should be noted here that, given the data, some of these coefficients are little more than conjecture as to the "true" removal rates. Future acquisition of more and better data is definitely indicated.

The appendices show how the choice of coefficients was made and give more Information on the computer module. 


\begin{tabular}{|c|c|c|c|}
\hline \multicolumn{4}{|c|}{$\begin{array}{l}\text { Table } 4.1 \\
\text { Elements }\end{array}$} \\
\hline Number & Type & Number & Type \\
\hline 1 & Ash & 24 & Hydrocarbons \\
\hline 2 & Sulfur (S) & 25 & Total solid waste \\
\hline 3 & Antimony (Sb) & 26 & Unreacted 11mestone \\
\hline 4 & Arsenic (As) & 27 & Calcium sulfite \\
\hline 5 & Beryllium (Be) & 28 & Calcium sulfate \\
\hline 6 & Cadmium (Cd) & 29 & Soda ash \\
\hline 7 & Chromi um (Cr) & 30 & Magnesi ur sulfite \\
\hline 8 & Copper (Cu) & 31 & Magnesiun oxide \\
\hline 9 & Iron (Fe) & 32 & Sodium bisulfite \\
\hline 10 & Lead $(\mathrm{Pb})$ & 33 & Sodiun sulfite \\
\hline 11 & Magnesi un (Mg) & 34 & Water \\
\hline 12 & Manganese (Mn) & 35 & Sulfur dioxide \\
\hline 13 & Mercury（Hg） & 36 & Nitrous oxides \\
\hline 14 & N1ckel (N1) & 37 & Carbon monoxide \\
\hline 15 & Selentum (Se) & 38 & Methane \\
\hline 16 & Silver (Ag) & 39 & Pyritic sulfur \\
\hline 17 & Thal11um (T1) & 40 & Carbon \\
\hline 18 & Zinc (Zn) & 41 & Btu \\
\hline 19 & Uranium-238(U) & 42 & Carbon dioxide \\
\hline 20 & Thoriun-232 (Th) & 43 & Sodium bicarbonate \\
\hline 21 & Radium-226 (Ra) & 44 & Sodium carbonate \\
\hline 22 & Radi um-228 (Ra) & 45 & Sodiun sulfate \\
\hline \multirow[t]{2}{*}{23} & Lead-210 (Pb) & 46 & Calcium carbonate \\
\hline & & 47 & Calciun oxide \\
\hline
\end{tabular}




\begin{tabular}{|c|c|c|c|c|c|c|c|}
\hline \multirow{2}{*}{$\begin{array}{l}\text { Fractions } \\
\text { Lable }\end{array}$} & \multicolumn{2}{|c|}{ (Coefficients) } & \multicolumn{2}{|c|}{$\begin{array}{c}\text { Table } 4.2 \\
\text { of Array Elements } \\
\end{array}$} & \multirow{2}{*}{$\begin{array}{l}\text { Golng to } \\
\text { Gas } \\
\text { Liquor }\end{array}$} & Solld Haste & \multirow{2}{*}{$\begin{array}{l}\text { Streams } \\
\text { aaccounted } \\
\text { for }\end{array}$} \\
\hline & $\begin{array}{c}\text { Array } \\
\text { Element } \\
\text { Ho. }\end{array}$ & $\begin{array}{l}\text { Bottom } \\
\text { Ash }\end{array}$ & 011 & Tar & & $\begin{array}{l}\text { Sulfur } \\
\text { Recovery }\end{array}$ & \\
\hline Ash & 1 & 0.9924 & 0.0025 & 0.005 & 0.0001 & 0.0 & 0.0 \\
\hline Total sulfur & 2 & 0.0025 & 0.005 & 0.015 & 0.0001 & 0.96 & 0.0174 \\
\hline Antimony & 3 & 0.50 & 0.01 & 0.04 & 0.45 & 0.0 & 0.0 \\
\hline Arsentc & 4 & 0.45 & 0.05 & 0.05 & 0.45 & 0.0 & 0.0 \\
\hline Berg111 um & 5 & 0.93 & 0.01 & 0.03 & 0.03 & 0.0 & 0.0 \\
\hline Cadmi un & 6 & 0.59 & 0.03 & 0.03 & 0.35 & 0.0 & 0.0 \\
\hline Chromi um & 7 & 0.93 & 0.01 & 0.05 & 0.01 & 0.0 & 0.0 \\
\hline Copper & 8 & 0.96 & 0.01 & 0.02 & $0.0 i$ & 0.0 & 0.0 \\
\hline Iron & 9 & 0.98 & 0.0005 & 0.019 & 0.0005 & 0.0 & 0.0 \\
\hline Lead & 10 & 0.87 & 0.01 & 0.11 & 0.01 & 0.0 & 0.0 \\
\hline Magnesi um & 11 & 0.98 & 0.0005 & 0.019 & 0.0005 & 0.0 & 0.0 \\
\hline Manganese & 12 & 0.98 & 0.001 & 0.016 & 0.003 & 0.0 & 0.0 \\
\hline Mercury & 13 & 0.03 & 0.05 & 0.55 & 0.35 & 0.0 & 0.02 \\
\hline Nickel & 14 & 0.95 & 0.01 & 0.03 & 0.01 & 0.0 & 0.0 \\
\hline Selent um & 15 & 0.10 & 0.01 & 0.01 & 0.01 & 0.0 & 0.87 \\
\hline Silver & 16 & 0.97 & 0.01 & 0.01 & 0.01 & 0.0 & 0.0 \\
\hline Thallium & 17 & 0.98 & 0.005 & 0.01 & 0.005 & 0.0 & 0.0 \\
\hline Zinc & 18 & 0.91 & 0.02 & 0.04 & 0.03 & 0.0 & 0.0 \\
\hline Uranl un-238 & 19 & 0.80 & 0.03 & 0.10 & 0.07 & 0.0 & 0.0 \\
\hline Thori um-232 & 20 & 0.80 & 0.03 & 0.10 & 0.07 & 0.0 & 0.0 \\
\hline Radium-226 & 21 & 0.80 & 0.03 & 0.10 & 0.07 & 0.0 & 0.0 \\
\hline Rad1 um -228 & 22 & 0.80 & 0.03 & 0.10 & 0.07 & 0.0 & 0.0 \\
\hline Lead-210 & 23 & $0.87^{\circ}$ & 0.01 & 0.11 & 0.01 & 0.0 & 0.0 \\
\hline $\begin{array}{l}\text { Total } \\
\text { solid waste }\end{array}$ & 25 & & See App & endix $4 A$ & $A$ and Table & le 4.3 & \\
\hline Water & 34 & & & & & & \\
\hline Pyritic sulfur & 39 & 0.0025 & 0.005 & 0.015 & 0.0001 & 0.96 & 0.0174 \\
\hline Carbon & 40 & 0.008 & 0.01 & 0.03 & 0.0001 & 0.0 & 0.0 \\
\hline
\end{tabular}


Table 4.3

Estimation of Water and Total

Solid Waste

\begin{tabular}{|c|c|c|}
\hline Haste Stream & Water & Total Waste \\
\hline Bottom ash & $\begin{array}{c}0.20 \text { (ash + carbon } \\
+ \text { sulfur) }\end{array}$ & $\begin{array}{l}\text { Ash }+ \text { carbon + sulfur } \\
+ \text { water }\end{array}$ \\
\hline 011 & 0.12 (total waste) & 0.0065 (total input coal) \\
\hline Tar & 0.20 (total waste) & 0.025 (total Input coal) \\
\hline Gas liquor & $\begin{array}{l}\text { Total waste - ash } \\
\text { - carbon - sulfur }\end{array}$ & 1.5 (total input coal) \\
\hline
\end{tabular}




\section{REFERENCES}

1. U.S. Environmental Protection Agency, Evaluation of Background Data Relating to New Source Performance Standards for Lurgt Gasification, EPA-600/7-77-057, June 1977.

2. R.G. Oldham and R. G. Wetherold, Assessment, Selection and Development of Procedures for Determining the Environmental Acceptability of Synthetic Fuel Plants based on Coal, Appendix 1, Radian Corp., FE-1795-3 (Pt. 1), revised May 1977.

3. D. W. Koppenal, Trace Element Studies on Coal Gasification Process Streams, Ph.D. dissertation, University of Missouri-Columbia, TID-29022, Sept. 1978.

4. U.S. Environmental Protection Agency, Environmental Assessment Data Base for B1gh-Btu Gasification Technology, Vol. 1-3, EPA-600/7-78-186a, Sept. 1978.

5. C. F. Blazek, N. R. Baker, and R. R. Tison, High-Btu Coal Gasification Processes, ANL/CES/TE 79-2, Jan. 1979.

6. U.S. Environmental Protection Agency, Environmental Assessment Report: Lurg1 Coal Gasification Systems for SNG, EPA-600/7-79-120, May 1979.

7. M. H. Somerville, J. L. Elder, and R. G. Todd, Trace Elements: Analygis of Their Potential Impact from a Coal Gasification Facility, from Technology and Use of Lignite, symposium sponsored by U.S. ERDA, GFERC/1C-77/1, May 1977 .

8. J. Antizzo, Background Material for the Workshop on Health and Environmental Effects of Coal Gasification and IIquefaction Technologies, M78-58, MITRE Corporation, McLean, VA, 1978. 
APPENDIX 4A

DETERMINATION OF SOLID WASTE CHARACTERISTICS:

TOTAL SOLID WASTE, WATER, CARBON, SULEUR, ASH

Descriptions of the estimation of the solid waste streams of 1nterest and thelr non-trace components (water, carbon, sulfur, and ash) are glven below. In most cases, it was determined that the quantity involved is best described as 3 fraction of the input quantity of the element or of the total coal. In this appendix, the "ash" in the coal will be differentlated from the "ash" remaining in the gasifier after gasification by referring to the lateer as "bottom ash."

\section{A.1 Total Sol1d Waste}

Bottom Ash (wet). The bottom ash in this module is calculated as the sum of its major components, 1.e.,

BOTTOM ASH = ASH + CARBON + SULFUR + WATER.

011. Table 4A.1 shows the input coal characteristics and waste production information for several types of coal. The oll produced is seen to range from 0.45 to 1.96 tons per 100 tons of the input coal type (1.e., the amount of oll produced is equal to 0.45 to $1.96 \%$ of the amount of input coal). Since most of these range from 0.45 to 0.76 , the total oil produced was taken to be 0.657 of the Input coa1, $1 . e$. ,

Total $011=0.0065 \cdot Q$

where $Q=$ total input coal. 
Table 44.1

Coal Characteristics, Total Waste Streems, Water Content*

\begin{tabular}{|c|c|c|c|c|c|c|c|}
\hline & \multicolumn{7}{|c|}{ 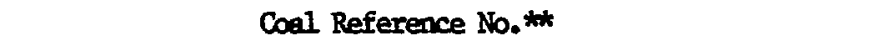 } \\
\hline & 1 & 2 & 3 & 4 & 5 & 6 & 9 \\
\hline Carban content of input coal & 50.56 & 64.15 & 64.11 & 74.15 & 48.21 & 45.74 & 39.05 \\
\hline Ash content of input coal & 9.71 & 9.07 & 8.10 & 7.73 & 29.07 & 4.75 & 4.20 \\
\hline Sulfir content of input coal & 1.092 & 2.810 & 3.135 & 2.519 & 0.396 & 0.807 & 0.799 \\
\hline Bottom ash production ratetstk & 12.0 & 10.0 & 9.2 & 8.1 & 31.0 & 10.0 & - \\
\hline Bottom ash produced (dry) & 9.036 & 8.977 & 8.102 & 7.729 & 28.52 & 6.402 & - \\
\hline Oil production rate & 2.6 & 0.5 & $0.6^{\circ}$ & 0.8 & 0.8 & 0.8 & 0.8 \\
\hline Oil produced & 1.958 & 0.449 & 0.528 & 0.763 & 0.736 & 0.512 & 0.492 \\
\hline \% Water & 22.3 & 4.3 & 5.4 & 15.4 & - & - & - \\
\hline Tar production rate & 2.6 & 2.7 & 3.5 & 3.8 & 1.5 & 1.5 & 1.5 \\
\hline Tar produced & 1.958 & 2.424 & 3.082 & 3.626 & 1.380 & 0.960 & 0.922 \\
\hline \% Water & 30.0 & 26.7 & 10.4 & 11.9 & - & - & - \\
\hline Cas Hquor production & 93.0 & 211.0 & 177.0 & 260.0 & 106.0 & 153.0 & 153.0 \\
\hline Gas Itquor produced & 70.03 & 189.41 & 155.87 & 248.09 & 97.52 & 97.95 & 94.00 \\
\hline
\end{tabular}

*All quantittes in tons/100 tons raw input coll unless otherwise noted.

* Data calculated fron References 4 and 6.

***Production rates given as percentage of amount of input coal (dry besis).

Tar. Table 4A.1 shows that tar production is from 0.92 to $3.6 \%$ of theinput coal. A "good" estimate of tar production is taken as $2.5 \%$ of the Inpucoal,

TOTAL TAR $=0.025 \cdot Q$.

Gas Liquor. Gas liquor production ranges from about 0.7 to 2.5 times the amount of total input coal. A rough average was taken to be 1.5 times the Input coal quantity,

TOTAL GAS LIQUOR $=1.5 \cdot \mathrm{Q}$.

\section{A.2 Water}

Bottom Ash. Water retained in the bottom ash waste stream is equal toapproximately one-fifth of the dry weight of the bottom ash ${ }^{2}$ :

$$
\text { WATER }=0.20 \cdot(\text { ASH + CARBON + SULFUR }) \text {. }
$$


011. The amount of water in the o1l ranges from 4.3 to $22.3 \%$. An average of $12 \%$ is taken as "typical":

WATER $=0.12 \cdot 011$

Tar. Water content of tar ranges from 10 to $30 \%$. The median of $20 \%$ was taken as a "good" estimate:

WATER $=0.20 \cdot$ Tar.

Gas Liquor. Since gas liquor is basically water, water content is assumed to be the total gas liquor produced minus its major dry components, WATER = GAS LIQUOR - ASH - CARBON - SULFUR.

\section{A.3 Carbon}

Table 4A.2 gives the distribution of carbon over three of the waste streams. Usable data are not available on the carbon content of gas 1iquor.

Table 4A.2

Carbon Distribution*

\begin{tabular}{lcccc}
\hline & \multicolumn{2}{c}{ Coal Reference No.** } & \multicolumn{1}{c}{ Re } \\
Component & 1 & 2 & 3 & 4 \\
\hline Carbon content of input raw coal & 50.56 & 64.15 & 64.11 & 74.15 \\
Carbon - \% of bottom ash & 6.5 & 4.3 & 2.9 & 7.6 \\
Carbon in bottom ash & 0.587 & 0.386 & 0.235 & 0.587 \\
\% of input carbon in bottom ash & 1.16 & 0.60 & 0.37 & 0.79 \\
Carbon - \% of oil (water-free basis) & 81.3 & 84.8 & 84.9 & 87.3 \\
Carbon in oil & 1.237 & 0.365 & 0.424 & 0.564 \\
\% of input carbon in oll & 2.45 & 0.57 & 0.66 & 0.76 \\
Carbon - of tar (dry basis) & 83.06 & 85.48 & 85.85 & 88.51 \\
Carbon in tar & 1.138 & 1.519 & 2.371 & 2.827 \\
\% of input carbon in tar & 2.25 & 2.37 & 3.70 & 3.81 \\
\hline *All quantities given in tons/100 tons raw input coal unless otherwise \\
noted. \\
**Data calculated from Reference 4.
\end{tabular}


Botton Ash. Bottom ash carbon content ranges from 0.37 to 1.16 percent of the input carbon. Carbon captured in bottom ash is assumed to be approximately 0.87 of the input carbon,

CARBON $=0.008 \cdot$ INPUT CARBON.

011. An estimate of $1 \%$ of the Input carbon gets captured in the o11 was assuned after Inspection of Table 4A.2,

CARBON $=0.01 \cdot$ INPUT CARBON.

Tar. An average of $3 \%$ of the Input carbon seems to get captured in the tar,

CARBON $=0.03 \cdot$ INPUT CARBON.

Gas Liquor. No usable data are evailable on carbon in gas 11quor; a token estimate of $0.01 \%$ is assumed since almost al1 carbon is probably removed in tar and oil separation.

\section{A. 4 sulfur}

Table 4A.3 gives the sulfur distribution across three of the solid waste streams. No usable data are available on the sulfur content of gas liquor. 2. 26\% of the sulfur is captured in the solid waste streams. About $96 \%$ is recovered in the sulfur process (Reference 1). The rest is assumed to escape with product and emission gases. Pyritic (inorganic) sulfur is assumed to follow the same distribution as total sulfur.

Bottom Agh. About $0.25 \%$ of the input sulfur is indicated as captured in the bottom ash, 1.e.,

$$
\text { SULFUR }=0.0025 \cdot \text { INPUT SULFUR }
$$




\section{Table 4 A.3}

Sulfur Distribution*

\begin{tabular}{|c|c|c|c|c|}
\hline Component & $1^{\text {Coal }}$ & $\begin{array}{c}\text { eference } \\
2 \\
\end{array}$ & $\begin{array}{c}0 . * * \\
3 \\
\end{array}$ & 4 \\
\hline $\begin{array}{l}\text { Sulfur content of input raw coal } \\
\text { Sulfur - } \% \text { of bottom ash } \\
\text { Sulfur in bottom ash } \\
\text { \% of input sulfur in bottom ash } \\
\text { Sulfur - \% of oil (water free basis) } \\
\text { Sulfur in oil } \\
\text { \% of input sulfur in oil } \\
\text { Sulfur - \% of tar (dry basis) } \\
\text { Sulfur in tar } \\
\text { \% of input sulfur in tar }\end{array}$ & $\begin{array}{l}1.092 \\
0.061 \\
0.0055 \\
0.50 \\
0.5 \\
0.0076 \\
0.70 \\
0.28 \\
0.0038 \\
0.35\end{array}$ & $\begin{array}{l}2.810 \\
0.054 \\
0.0048 \\
0.17 \\
2.4 \\
0.0103 \\
0.37 \\
1.7 \\
0.0302 \\
1.07\end{array}$ & $\begin{array}{l}3.135 \\
0.029 \\
0.0023 \\
0.07 \\
2.3 \\
0.0115 \\
0.37 \\
2.4 \\
0.0663 \\
2.11\end{array}$ & $\begin{array}{l}2.519 \\
0.029 \\
0.0022 \\
0.09 \\
1.5 \\
0.0097 \\
0.39 \\
1.5 \\
0.0579 \\
1.90\end{array}$ \\
\hline
\end{tabular}

*All quantities given in tons/100 tons raw input coal unless otherwlse noted **Data calculated. from Reference 4.

011. Inspection of Table $4 \mathrm{~A} .3$ seems to Indicate that $0.5 \%$ of the lnput sulfur is captured in the ofl.

SULFUR $=0.005$ - INPUT SULFUR.

Tar. The range of sulfur contained in the tar seems to show that $1.5 \%$ of the input amount of sulfur may be captured in the tar.

SULFUR $=0.015 \cdot$ INPUT SULFUR.

Gas Liquor. As with the amount of carbon in the gas liquor, sulfur is given a token fraction that is assumed captured in the gas liquor.

SULFUR $=0.0001 \cdot$ INPUT SULFUR.

4A. 5. Ash

Table 4A.4 gives the distribution of the ash content of coal through the bottom ash, tar, and ofl streams. No data are available on the ash content of gas 1lquor; as with carbon and sulfur, the gas liquor is assigned a tokee negligible amount of captured ash. Since the total amount of ash found in the 
Table 4 A. 4

Ash Distribution*

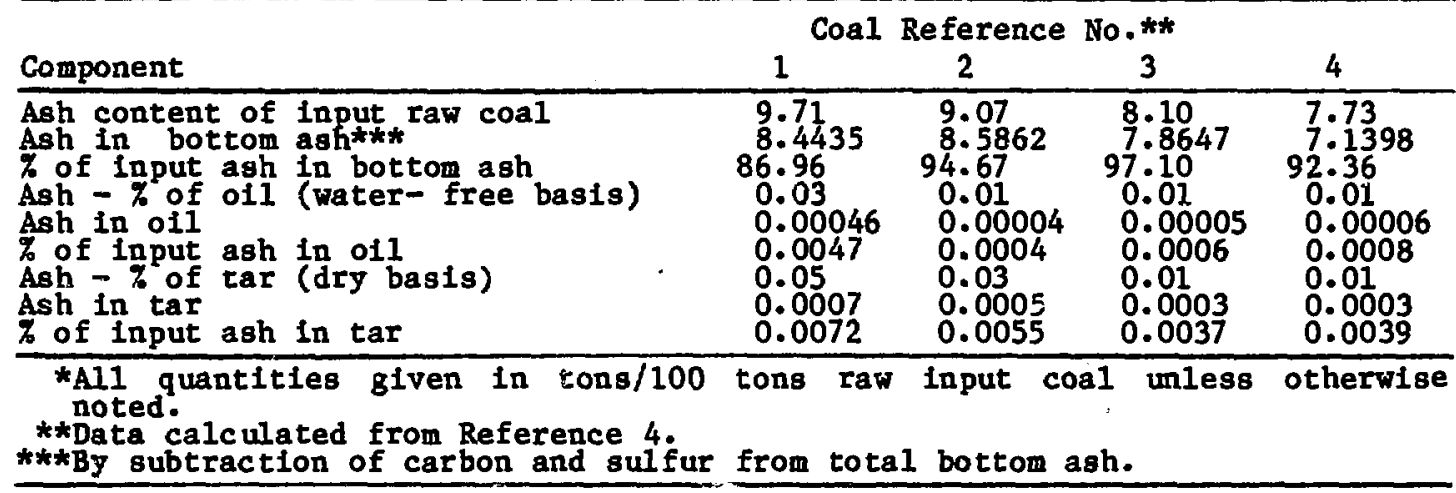

data is always several percent below $100 \%$ of the coal ash content, the numbers had to be Increased slightly from what the data indicate is the "true" amount of captured ash in the waste streams. The following are the estimates for ash retention:

$\begin{array}{ll}\text { BOTTOM ASH: } & \text { ASH }=0.9924 \cdot \text { INPUT ASH } \\ \text { OIL: } & \text { ASH }=0.0025 \cdot \text { INPUT ASH } \\ \text { TAR } & \text { ASH }=0.005 \cdot \text { INPUT ASH } \\ \text { GAS LIQUOR: } & \text { ASH }=0.0001 \cdot \text { INPUT ASH }\end{array}$

4A.6. Sulfur Recovery

Although marketable sulfur is usually produced through the sulfur recovery process, and therefore the sulfur cannot really be considered a waste stream, it is included in this module as such. It is assumed that the stream Is pure sulfur; therefore the total solid waste vector element will be equal to the total. sulfur element. As mentioned before, $96 \%$ of the input coal sulfur content is assumed to be recovered in this process. All other elements In the stream are 0. 
AF PENDIX 4B

DETERMINATION OF SOLID WASTE CHARACTERISTICS:

FRACTIONATION FACTORS OF TRACE ELEMENTS

As mentioned previously, data on trace elements are highly variable. Some attempts have been made to follow the paths of the trace elements as they go through the gasification process; however, because of analytic measurement error, poor sampling procedures (from a strict testing standpoint), or unknown factors, recovered mass balances of trace elements of from 10 to over 2000 percent are not unknown (or uncommon).

An attempt is made here to split the trace elements so that their total mass balance is accounted for in the solid waste streams. Although some of the trace elements are probably lost to catalysts (in shift reaction and methanation) and some to fugitive air emissions, these amounts are assumed to be negliglble and, as far as this moáule is concerned, nonexistent. This assumption is not without precedent, as it has been made in other analyses (Reference 1, p. 36; Reference 7, Table 5; Reference 4, Append1x 4A).

While varying amounts of the total mass of the trace elements in the Input coal have been found, mercury and selenlum are consistently short of a total mass balance. Therefore, these two are assumed to have lost some amount to unknown processes and are not completely accounted for in the solld waste streams. All other elements have been normalized so that $100 \%$ of the input mass has come out in the solid waste streams.

Table 4B.1 gives the input coal content of trace elements for which trace element distributions have been calculated. Tables 4B.2 to 4 B.5 give the amounts of the elements (as fraction of input element) In the solid waste 
Table 4B.1

Coal Content of Trace Elements (ppm)

Corl Reference No.

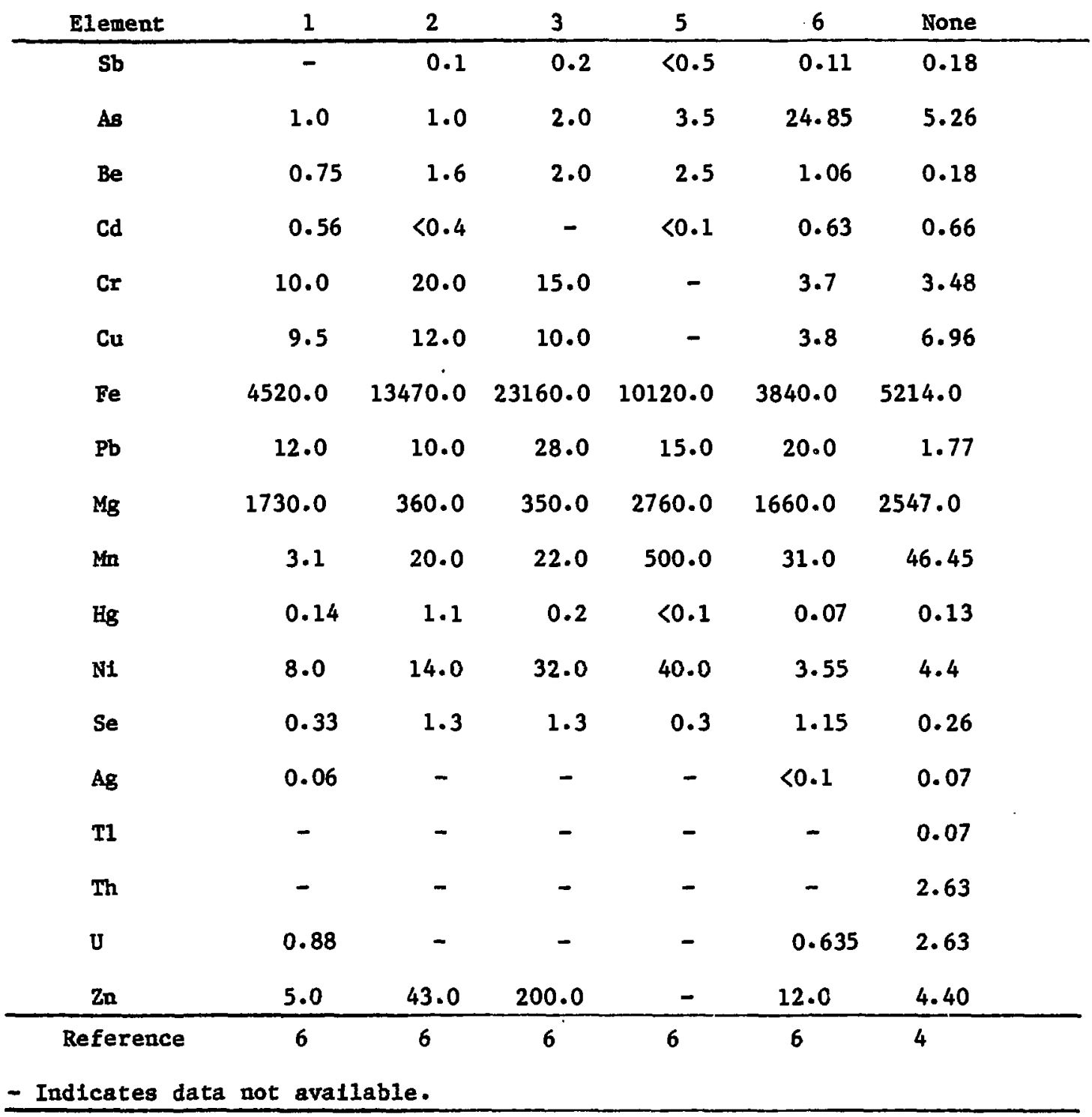


Table $4 \mathrm{~B} .2$

Fraction of Input Trace Elements in Bottom Ash

\begin{tabular}{|c|c|c|c|c|c|c|c|c|c|c|}
\hline \multirow[b]{2}{*}{ Element } & \multicolumn{10}{|c|}{ Coel Reference $\mathrm{No} . *$} \\
\hline & 1 & 2 & 2 & 3 & 5 & 6 & 6 & None & Honet*k & Nonekst \\
\hline $\mathbf{s b}$ & - & 0.18 & $3 . \pi$ & 7.70 & 0.29 & 0.58 & 19.21 & 0.10 & $0.40(0.50)$ & $1.63(1.00)$ \\
\hline As & 1.96 & 0.01 & 0.27 & 0.01 & $0.08-0.16$ & 0.15 & 0.19 & 0.01 & $0.36(0.27)$ & $1.02(0.91)$ \\
\hline $\mathrm{Be}$ & 0.34 & 0.79 & 0.67 & 0.81 & 0.006 & 0.30 & 0.36 & 0.80 & $0.01(0.33)$ & $2.46(0.99)$ \\
\hline $\mathrm{cd}$ & 0.39 & 0.07 & 0.36 & - & 0.29 & 0.10 & 0.05 & - & $0.40(0.52)$ & $0.06(0.15)$ \\
\hline Gr & 3.98 & 3.37 & 0.95 & 3.20 & - & 0.69 & 2.42 & 3.00 & - & $2.93(0.98)$ \\
\hline $\mathrm{Cu}$ & 1.24 & 1.79 & 0.43 & 2.21 & - & 0.84 & 0.45 & 2.00 & - & $0.28(0.94)$ \\
\hline $\mathrm{Fe}$ & 1.57 & 0.80 & 0.9 & 0.48 & 0.99 & - & 1.28 & - & - & $1.10(0.99)$ \\
\hline $\mathrm{Fb}$ & 0.30 & 0.86 & 0.40 & 0.58 & 0.95 & 0.64 & 0.19 & 0.80 & $1.80(0.94)$ & $2.35(0.88)$ \\
\hline $\mathrm{Mg}$ & 1.22 & 1.50 & 0.90 & 0.97 & 1.05 & - & 1.62 & - & - & $1.29(0.99)$ \\
\hline $\mathbf{M n}$ & 23.03 & 0.90 & 8.34 & 1.12 & 1.14 & - & 1.57 & 0.90 & $1.54(0.99)$ & $1.10(0.99)$ \\
\hline $\mathrm{Hg}$ & 0.02 & 0.003 & 0.004 & 0.01 & - & 0.09 & 0.05 & 0.01 & $0.40(0.52)$ & $0.03(0.01)$ \\
\hline $\mathbf{N H}$ & 2.26 & 2.92 & 0.57 & 1.14 & $1.07-1.43$ & 0.45 & 0.45 & 1.25 & $1.54(0.994)$ & $0.42(0.93)$ \\
\hline Se & 0.60 & - & 0.07 & - & - & 0.08 & 0.03 & - & - & $0.14(0.14)$ \\
\hline A & 0.35 & - & - & - & - & 0.45 & 0.64 & - & - & $1.10(1.00)$ \\
\hline $\mathrm{TI}$ & - & - & $=$ & - & - & - & - & - & - & $5.50(1.00)$ \\
\hline Th & - & - & - & - & - & - & - & - & - & $1.24(0.99)$ \\
\hline $\mathbf{U}$ & 1.33 & - & - & - & - & 0.60 & 0.71 & - & - & $0.19(0.94)$ \\
\hline $\mathbf{Z n}$ & 0.58 & 0.98 & 0.84 & 0.65 & - & 0.00 & 20.05 & 0.90 & $-(1.00)$ & $0.17(0.75)$ \\
\hline $\begin{array}{l}\text { Referenc } \\
\text { - Indic } \\
\text { * Coals } \\
\text { * Numbe }\end{array}$ & $\begin{array}{l}\text { ce } \\
\text { cates } \\
\mathrm{s} \mathrm{No} .2 \\
\text { ers in }\end{array}$ & $\begin{array}{l}6 \\
\text { a not } \\
\text { and tho. } \\
\text { renthe }\end{array}$ & $\begin{array}{l}\text { vallabl } \\
6 \text { each } \\
\text { is are }\end{array}$ & $\begin{array}{l}\quad 6 \\
\text { e. } \\
\text { had two } \\
\text { fractio }\end{array}$ & 6 & Dill & 6 & 20 & 4 & 3 \\
\hline
\end{tabular}


Table 4B.3

Fraction of Input Trace Elements in 011

Coal Reference No.

\begin{tabular}{|c|c|c|c|c|c|c|c|}
\hline Element & 5 & 6 & 9 & & ne* & None & \\
\hline $\mathbf{S b}$ & 0.49 & - & 0.002 & 0.005 & $(0.006)$ & 0 & $(0)$ \\
\hline As & $0.221-0.553$ & $0.024-0.036$ & 0.005 & 0.052 & $(0.039)$ & 0.036 & $(0.032)$ \\
\hline $\mathrm{Be}$ & $0.0002-0.0003$ & $0.0005-0.008$ & 0.001 & 0.0001 & $(0.003)$ & 0 & $(0)$ \\
\hline $\mathrm{Cd}$ & 0.191 & 0.035 & 0.020 & 0.011 & $(0.014)$ & 0.006 & $(0.016)$ \\
\hline$C r$ & - & $0.024-0.105$ & 0.0003 & & - & 0.009 & $(0.003)$ \\
\hline $\mathrm{Cu}$ & - & $0.014-0.076$ & 0.004 & & - & 0.002 & $(0.007)$ \\
\hline $\mathrm{Fe}$ & - & 0.0007 & - & & - & 0.0002 & $(0.0002)$ \\
\hline $\mathrm{Pb}$ & $0.004-0.008$ & $0.012-0.347$ & 0.0002 & 0.0002 & $(0.001)$ & 0.0003 & $(0.007)$ \\
\hline $\mathrm{Mg}$ & - & 0.0001 & - & & - & 0.0001 & $(0.0001)$ \\
\hline Mn & NG & $0.0005-0.002$ & - & & NG & 0.0001 & $(0.0001)$ \\
\hline $\mathrm{Hg}$ & 0.099 & $0.123-0.221$ & 0.033 & 0.005 & $(0.006)$ & 0.011 & $(0.005)$ \\
\hline N1 & $0.002-0.003$ & $0.015-0.076$ & 0.005 & 0.0001 & (NG) & 0.003 & $(0.007)$ \\
\hline Se & - & $0.008-0.009$ & 0.0003 & & - & 0.005 & $(0.013)$ \\
\hline $\mathrm{Ag}$ & - & - & 1.720 & & - & 0 & $(0)$ \\
\hline $\mathrm{T} 1$ & - & - & - & & - & 0 & $(0)$ \\
\hline Th & - & - & - & & - & 0 & $(0)$ \\
\hline $\mathrm{U}$ & - & - & 0.03 & & - & 0 & $(0)$ \\
\hline $\mathrm{Zn}$ & - & $0.006-0.122$ & 0.001 & - & - & 0.004 & $(0.016)$ \\
\hline Reference & 6 & 6 & 6 & 4 & 4 & 3 & \\
\hline $\begin{array}{l}\text { NG Indic: } \\
\text { - Indice } \\
\text { * Numbe } \\
\text { across }\end{array}$ & $\begin{array}{l}\text { ates negligible } \\
\text { ates data not a } \\
\text { Is in parenthes } \\
3 \text { the four wast }\end{array}$ & $\begin{array}{l}\text { amount }(<.000 \\
\text { vallable. } \\
1 \text { s are fract } \\
\text { streams. }\end{array}$ & which & have & been nor & lallzed & to $100 \%$ \\
\hline
\end{tabular}


Table 4B.4

Fraction of Input Trace Elements in Tar

Coal Reference No.

\begin{tabular}{|c|c|c|c|c|c|c|c|}
\hline Element & 5 & 6 & 9 & Nor & $n e^{*}$ & & one* \\
\hline $\mathbf{S b}$ & 0.128 & - & 0.009 & 0.03 & $(0.38)$ & 0 & $(0)$ \\
\hline As & $0.056-0.139$ & 0.014 & 0.009 & 0.025 & $(0.019)$ & 0.048 & $(0.043)$ \\
\hline $\mathrm{Be}$ & 0.071 & - & 0.005 & 0.005 & $(0.17)$ & 0.022 & $(0.009)$ \\
\hline $\mathrm{Cd}$ & 0.052 & 0.034 & 0.033 & 0.005 & $(0.006)$ & 0.017 & $(0.045)$ \\
\hline $\mathrm{Cr}$ & - & $0.05-0.214$ & 0.0009 & - & & 0.054 & $(0.018)$ \\
\hline $\mathrm{Cu}$ & - & $0.035-0.186$ & 0.0003 & - & & 0.016 & $(0.053)$ \\
\hline $\mathrm{Fe}$ & - & 0.016 & - & - & & 0.011 & $(0.010)$ \\
\hline $\mathrm{Pb}$ & 0.454 & $0.007-0.203$ & 0.003 & 0.082 & $(0.043)$ & 0.291 & $(0.109)$ \\
\hline $\mathrm{Mg}$ & - & 0.004 & - & - & & 0.011 & $(0.009)$ \\
\hline Mn & 0.0004 & $0.013-0.056$ & - & NG & & 0.008 & $(0.007)$ \\
\hline $\mathrm{Hg}$ & 0.649 & $3.64-6.55$ & 0.054 & 0.049 & (NG) & 0.821 & $(0.382)$ \\
\hline N1 & 0.007 & $0.038-0.186$ & 0.06 & 0.0005 & $(0.0003)$ & 0.026 & $(0.057)$ \\
\hline Se & - & $0.006-0.008$ & 0.009 & - & & 0.011 & $(0.028)$ \\
\hline$A B$ & - & - & 0.562 & - & & 0 & $(0)$ \\
\hline T1 & - & - & - & - & & 0 & $(0)$ \\
\hline Th & - & - & - & - & & 0.008 & $(0.034)$ \\
\hline $\mathbf{u}$ & - & $0.142-0.526$ & 0.253 & - & & 0.013 & $(0.062)$ \\
\hline $\mathbf{2 n}$ & - & $0.004-0.089$ & 0.031 & - & & 0.014 & $(0.011)$ \\
\hline Reference & 6 & 6 & 6 & 4 & & 3 & \\
\hline $\begin{array}{l}\text { NG Indice } \\
\text { - Indice } \\
\text { * Numbe } \\
\text { across }\end{array}$ & $\begin{array}{l}\text { ates negligib] } \\
\text { ates data not } \\
\text { rg in parenth } \\
s \text { the four was }\end{array}$ & $\begin{array}{l}\text { amount ( }<.000 \\
\text { vallable. } \\
\text { sis are fract } \\
\text { e streams. }\end{array}$ & ng which & have & been nor & nalized & to $100 \%$ \\
\hline
\end{tabular}




\begin{tabular}{|c|c|c|c|c|c|c|c|}
\hline \multirow{3}{*}{$\frac{\text { Element }}{\mathrm{Sb}}$} & \multirow{3}{*}{$\frac{1}{-}$} & \multicolumn{6}{|c|}{ Coal Reference No. } \\
\hline & & \multirow[t]{2}{*}{6} & \multirow{2}{*}{$\frac{9}{0.09}$} & \multicolumn{2}{|c|}{ None* } & \multicolumn{2}{|c|}{ None* } \\
\hline & & & & 0.36 & $(0.45)$ & 0 & $(0)$ \\
\hline As & $0.008-1.75$ & $0.003-0.005$ & 0.282 & 0.90 & $(0.672)$ & 0.019 & $(0.017)$ \\
\hline $\mathrm{Be}$ & $0.193-0.220$ & - & 0.026 & 0.016 & $(0.53)$ & 0 & (0) \\
\hline Cd & $0.088-0.226$ & 0.311 & 0.133 & 0.35 & $(0.455)$ & 0.302 & $(0.794)$ \\
\hline Cr & $0.057-0.228$ & $0.003-0.014$ & 0.0004 & - & - & 0.006 & $(0.002)$ \\
\hline $\mathrm{Cu}$ & $0.070-0.078$ & $0.003-0.017$ & 0.012 & - & - & 0.002 & $(0.005)$ \\
\hline Fe & - & NG & - & - & - & 0.0001 & $(0.0001)$ \\
\hline $\mathbf{P b}$ & $0.007-0.165$ & $0.0003-0.007$ & 0.003 & 0.032 & $(0.017)$ & 0.003 & $(0.001)$ \\
\hline $\mathrm{Mg}$ & - & 0.0002 & - & - & - & 0.0002 & $(0.0002)$ \\
\hline Mn & $0.002-0.003$ & $1.86-3.34$ & - & 0.32 & $(0.002)$ & 0.001 & $(0.001)$ \\
\hline Hg & $0.229-0.355$ & $1.86-3.34$ & 0.015 & 0.32 & $(0.416)$ & 1.288 & $(0.599)$ \\
\hline $\mathbf{N} \mathbf{1}$ & $0.025-.0 .175$ & $0.001-0.005$ & 0.016 & 0.006 & $(0.004)$ & 0.001 & $(0.003)$ \\
\hline Se & 0.106 & $0.003-0.004$ & 2.21 & - & - & 0.006 & $(0.015)$ \\
\hline $\mathrm{Ag}$ & 0.20 & - & 6.27 & - & - & 0 & $(0)$ \\
\hline T1 & - & - & - & - & - & 0 & $(0)$ \\
\hline Th & - & - & - & - & • & 0 & $(0)$ \\
\hline U & 0.119 & - & 0.063 & - & - & 0 & (0) \\
\hline $\mathbf{Z n}$ & $0.005-0.021$ & $0.016-0.327$ & 0.342 & - & 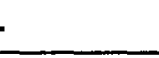 & 0.045 & $(0.103)$ \\
\hline Reference & 6 & 6 & 6 & & 4 & 3 & \\
\hline $\begin{array}{l}\text { NG Indica } \\
\text { - Indica } \\
\text { * Number } \\
\text { across }\end{array}$ & $\begin{array}{l}\text { tes negligibl } \\
\text { tes data not } \\
\text { ts in parenth } \\
\text { the four was }\end{array}$ & $\begin{array}{l}\text { amnunt }(<.0001 \\
\text { vatiable. } \\
\text { sis are fract1 } \\
\text { e streams. }\end{array}$ & s which & have & been no: & ma11zed & to $100 \%$ \\
\hline
\end{tabular}


streams which were found for some or all of these coals, as data were available. Tables 4B.2 to $4 \mathrm{~B} .5$ also have some data for the references where this fraction was already calculated. Note that when the numbers are greater than one, more of that element has been found in the waste stream then was in the input coal. Some authors explain this by saying that the extra elements found are from the construction materials in the gasifier system ${ }^{3}$. The magnitude of the amounts involved preclude this as an explanation.

After examining the data in Tables 4B.2 to 4B.5, an attempt was made to distribute the trace elements across the waste streams such that there was some agreement with the data and that the mass of the elements was totally accounted for (except for those elements noted above). Different observations of the data at different times have yielded varying results for some of the trace elements, although the difference was in the size of the coefficients: In general, the relative distribution of each element across the waste stredm was not changed significantly. Certainly, almost any reasonable estimate of a coefficient can be no better or worse than those decided upon here. Table 4.2 in the main report gives the latest estimation of the coefficients.

Special Notes: No data were avallable on the distributions of radiun-226, radium-228 or lead-210. Also, very few data were avallable for urantum and thorfum. It was therefore decided that all radioactive elements follow the same distribution, except for lead-210 which is distributed as $\mathrm{Pb}$.

There is only one measurement for thallium, which indicates that all of it gets captured in the bottom ash. There is no reason to assume that all of the thellium is captured here, although the bulk of it may be; the coefficients for thallium reflect this. 


\section{APPENDIX 4C \\ DESCRIPTION OF COMPUTER MODULE}

The coal gasification solid waste module consists of one subroutine and a data file containing the fraction of the waste components that are removed to the solid waste. The module is set into motion by a call to LURGI:

CALL LLRGI (Q, COAL, CHAR, OIL, TAR, LIQUOR, SREC),

where

$$
\begin{aligned}
& Q=\text { total mass of Input coal } \\
& \text { COAL }=\text { Input coal characteristic vector } \\
& \text { CHAR = bottom ash output characteristic vector } \\
& \text { OIL = oll output characteristic vector } \\
& \text { TAR = tar output characteristic vector } \\
& \text { LIQUOR = gas liquor output characteristic vector } \\
& \text { SREC = sulfur recovery output characteristic vector }
\end{aligned}
$$

The subroutine calculates the solid waste characteristics of each waste stream and prints them out (see Append1x 4D for sample output). The data f1le contalns the coefflclents of all elements that are removed at a constant rate and can be calculated by a simple multiplication. All elements in the input vector that are empty, are not applicable to this module, or are calculated other than by a single multiplication (1.e., water and some total wastes) have corresponding coefficients of zero.

All calculations (including empty and nonapplicable elements) are done through DO loops in the module. The water and total solid waste elements are calsulated separately. 
The module prints out the input coal and output waste vectors (applicable elements only). If this printout is not desired at some future time, the printout section can simply be removed with no effect on the solid waste calculations. All vectors are returned to the calling progran intact, Inlcuding the input coal characteristics.

The data file is presently read in as "TAPEl". 


\section{APPENDIX 4D}

COMPUTER CODE AND SAMPLE OUTPUT

This section sets out the computer code used for the coal gasification module and the data file of coefficients, with a sample input and the resulting output. Table 4D.1 gives the coal characteristics used as input. The quantity of coal (Q) in the input is 100,000 tons.

At present the main program of the code is used only to set the Input variables.

Table 4D.1

Input Characteristics of Coal

\begin{tabular}{lc}
\hline Element & Input Quantity (tons) \\
\hline Ash & 18700.00 \\
Sulfur & 3000.00 \\
Antimony & 0.07 \\
Arsenic & 2.70 \\
Berylilum & 0.50 \\
Cadmium & 0.125 \\
Chromi um & 3.00 \\
Copper & 1.18 \\
Iron & 2700.00 \\
Lead & 1.14 \\
Magnesium & 118.00 \\
Manganese & 7.40 \\
Mercury & 0.017 \\
Nickel & 2.00 \\
Selenium & 0.02 \\
Silver & 0.01 \\
Thallium & 0.66 \\
Zinc & 1.69 \\
Uranium & 0.07 \\
Thorium & 0.66 \\
Pyritic sulfur & 1870.00 \\
Carbon & 64100.00 \\
Btu & $2.3 \times 10^{12}$ \\
\hline
\end{tabular}


PROGRAM CLL (TAPE), OUTPUT , TAPEC=OUTPUT)

DIMENSION COAL (5O)

REAL CHAR(50), OIL (50), TAR(50), LIQUOR(50), SREC(50)

$Q=100000$

$\operatorname{COAL}(1)=18700$.

$\operatorname{COAL}(2)=3000$.

$\operatorname{COAL}(3)=.07$

$\operatorname{COAL}(4)=2.7$

$\operatorname{COAL}(5) \times .5$

$\operatorname{COAL}(6)=.125$

$\operatorname{COAL}(7)=3$

COAL $(8)=1.18$

$\operatorname{COAL}(9)=2700$

$\operatorname{COAL}(10)=1.14$

COAL $(11)=118$.

$\operatorname{COAL}(12)=7.4$

$\operatorname{COAL}(13)=.017$

$\operatorname{COAL}(14)=2$

$\operatorname{COAL}(15)=.02$

$\operatorname{COAL}(16)=.01$

$\operatorname{COAL}(17)=.66$

$\operatorname{COAL}(18)=1.69$

$\operatorname{COAL}(19)=.07$

$\operatorname{COAL}(20)=.66$

DO $10 \quad I=21,39$

COAL $(1)=0$.

10 CONT INUE

$\operatorname{COAL}(39)=1870$.

COAL $(40)=64100$

COAL $(41)=2$. 3E 12

DO $20 \quad[=42,50$

$\operatorname{COAL}([)=0$.

2O CONT INUE

CALL LURG I $(Q$, COAL, CHAR, O $i \mathrm{~L}, T A R$, LIQUOR, SREC

STOP

END 
SUBROUT INE LURG I (O, COAL, CHAR, OIL, TAR, L J QUOR, SREC)

DIMENS ION COAL (50), CHAR (50), OIL (50), TAR (50), LIQUOR (50), SREC (50)

REAL LIQUOR, CHARC ( 50 ), OILC (50), TARC (50), LI QUORC (50), SRECC (50)

C - COEFFICIENTS FOR DETERMINING ELEMENTAL SPLIT BETWEEN

- THE OUTPUT PRODUCT AND WASTE STREAMS READ IN

READ $(1,1000)($ CHARC $(1), 01 \operatorname{LC}(1), \operatorname{TARC}(1), \operatorname{LIQUORC}([), \operatorname{SRECC}(1), 1=1,50)$

1000 FORMAT (F9.5.4F10.5)

C * CalCULATION OF INPUT RA-226.RA-22E PB-210 IF NOT given

IF (COAL (21), EQ. 0. I COAL $(21)=3.38 E-7-\operatorname{COAL}(19)$

IF (COAL (22) .EQ. D. ICOAL (22) $=4.01 E-10 \cdot \operatorname{COAL}(20)$

IF ( COAL (23) .EQ. O. I COAL (23) $=4.37 E-9 \cdot \operatorname{COAL}(19)$

C - CalCulation of amount of each Element in Each output stream

DO $10 \quad l=1,24$

CHAR $(I)=\operatorname{CHARC}(1) \cdot \operatorname{COAL}(1)$

OIL ( I I=O!LC (]) +COAL (I)

TAR( (I) TARC (1)+COAL (I)

L I QUOR ( ] ) =L I QUORC ( I) *COAL ( I)

SREC ( [ ] $=\operatorname{SRECC}(1) \cdot \operatorname{COAL}(I)$

10 CONT INUE

C * Elements not appl !CaBle to gasification set to zero

DO $20 \quad I=26,33$

CHAR $(1)=0$.

OIL $(I)=0$.

$\operatorname{TAR}(1)=0$.

$\operatorname{LIQUOR}(\rrbracket)=0$

SREC $(1)=0$

20 CONTINUE

DO $30 \quad l=35,50$

CHAR (I)=CHARC ( I) $\cdot \operatorname{COAL}(1)$

OIL (I j =OILC (I)*COAL (I)

$\operatorname{TAR}(1)=\operatorname{TARC}(1) * \operatorname{COAL}(1)$

LIQUOR ( I) = L I QUORC (I) +COAL (I)

$\operatorname{SREC}(1)=\operatorname{SRECC}(1) * \operatorname{COAL}(1)$

30 CONTINUE

C - calculation of water content and total Quantity of BotTom ash CHAR $(34)=.2 *($ CHAR $(1)+\operatorname{CHAR}(2)+$ CHAR $(40))$

CHAR $(25)=\operatorname{CHAR}(1)+\operatorname{CHAR}(2)+\operatorname{CHAR}(40)+\operatorname{CHAR}(34)$

C - CALCULATION OF TOTAL QUANTITY AND WATER CONTENT OF OIL $01 L(25)=.01 \div 0$

OIL $(34)=.12 * 0 I L(25)$

C - CALCULATION OF TOTAL QUANTITY AND WATER CONTENT OF taR $\operatorname{TAR}(25)=.03 * 0$

TAR $(34)=.20 *$ TAR(25)

C * calculation of total quantity and water content uf gas liQuor LIQUOR $(25)=1.5 \cdot 0$ LI QUOR ( 34 ) = L I QUOR (25) -L I QUOR (1) -L I QUOR (2) -L [ QUOR (40)

C * CalCulation of total Quantity and water content of SUlfuR product $\operatorname{SREC}(25)=\operatorname{SREC}(2)$ $\operatorname{SREC}(34)=0$.

PRINT OUT OF DATA

WRI TE (2,2000) Q.COAL (1), CHAR(1), OIL (1), TAR(1), LI QUOR(1), SREC (1), -COAL (2), CHAR(2), OIL (2), TAR( $(2), L$ IQUOR (2), SREC ( 2$)$. 
-COAL (3), CHAR ( 3) , OIL (3), TAR (3), L I QUOR (3), SREC (3),

-COAL (4), CHAR (4), OIL (4), TAR ( 4 ), L IQUOR ( 4$),$ SREC ( 4$)$

2000 FORMAT ( IH! ,5X, *INPUT COAL:*2X,EI2.5/1X, "ELEMENT * T 16, * [NPUT COAL* -T31. *ASH*, T46, *OIL*, T61, *TAR*, T76. "LI IQUCR*, T9! *SULFUR RECOVERY*I

$-1 \times, \mid 05(*-*) 1$

$-1 X . A S H *, T 16, E 12.5,5(3 X, E 12.5) /$

$-1 X .1 H^{*},-$ SULFUR*.T $\left.16, E 12.5,5(3 x, E) 2.51\right)$

$-1 X$.ANTIMONY* TIS,EIZ, 5, 5(3X,EIZ, 5)

-IX. *ARSENIC. TIG,EI2.5,5(3X,EI2.5))

WRI TE (2.200 I ICOAL (5), CHAR (5), OIL (5), TAR(5), LIQUOR(5), SREC (5),

-COAL (6), CHAR (6), OIL (6), TAR (6), LIQUOR (6) , SREC (6).

-COAL (7), CHAR (7), OIL (7), TAR (7), LI I UUOR (7), SREC (7),

-COAL (8), CHAR (8), OIL (8), TAR ( 8 ), L I QUOR (8), SREC (8)

200I FDRMAT ( IX,*BERYLLIUM*,TI6,EI2.5.513X,El2.5)/

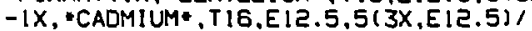

$-1 X$, CHROMIUM* TI6,El2.5.5(3X,El2.5)

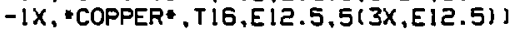

WR I TE ( 2,2002 ) COAL ( 9 ), CHAR ( 9$),$ OIL $(9), \operatorname{TAR}(9), L I Q U O R(9), \operatorname{SREC}(9)$,

-COAL (10), CHAR (10), OIL (10), TAR(10), LIQUOR (10), SREC (10).

-COAL (11), CHAR (11), OIL (11), TAR (11), LIQUOR (11), SREC (11). -COAL (12),CHAR (12),OIL (12),TAR (12),LIQUOR (12), SREC (12)

2002 FORMAT $(1 X, * I R O N *, T 16, E 12.5,5(3 X, E I 2.5) /$

-IX. "LEAD.T T $16, E 12,5,5(3 X, E[2,5) /$

- IX. MAGNESIUM*, T16,E $12.5,5(3 X, E 12.5)$

- IX. MANGANESE . T $16, E(2.5,5(3 X, E 12.5))$

WRI TE (2,2003) COAL (13), CHAR (13), OIL (13),TAR (13), LIQUOR (13), SREC (13)

,$- \operatorname{COAL}(14)$, CHAR ( 14), O(L (14), TAR (14), LIQUOR (14), SREC (14).

-COAL (15), CHAR (15), OIL (15), TAR (15), LIQUOR (15), SREC (15).

-COAL (16), CHAR (16), OIL (16),TAR (16), LIQUOR (16), SREC (16)

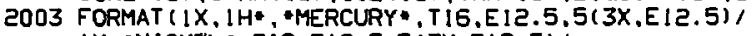

$-1 X,+N I C K E L$ - T I6.E12.5.5i (3X.El2.5)i

$-1 X, 1 H *$. SELENIUM*.T I6.E $12.5 .5(3 X, E 12.5) /$

$-1 X, * S I L V E R *, T 16, E i 2,5,5(3 X, E l 2,5)\}$

WR I TE (2, 2004) COAL (17), CHAR (17), OIL (17), TAR (17), LIQUOR ( 17), SREC (17)

-. COAL ( 18$),$ CHAR (18), OIL (18), TAR (18), LI QUOR (18), SREC ( 18 ).

-COAL (19), CHAR (19), OIL (19), TAR (19), L I QUOR (19), SREC (19),

-COAL (20),CHAR(20), OIL (20), TAR (20), L IQUOR (20), SREC (20)

2004 FORMAT I IX, "THALL IUM*, T I6,EI2.5,5(3X,EI2.5)/

$-1 X, *$ ZINC*,T16,EI2.5, ड (3X,EI2.5)/

$-1 X$. URANIUM*,TIG,E12.5.5(3X,E)

$-1 X . *$ THORIUM-232*, T1E, EI2.5,5(3X,E12.5))

WRITE (2, 2005)COAL (21), CHAR (21).OIL (21), TAR(21), L IQUOR(21), SREC (21)

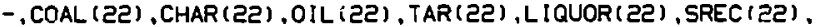

-COAL (23), CHAR (23), OIL (23), TAR (23), LI QUOR (23), SREC (23).

-COAL (25), CHAR(25), OIL (25), TAR (25), L I QUOR (25) ,SREC (25)

2005 FORMAT (IX, -RADIUM-2ZG*,TIS,EI2.5,5(3X.El2.5))

-IX, *RADIUM-2Z8*,TI6,EI2.5,5(3X,EI2.5);

$-1 X$. $L E A D-210 ., T 16, E 12.5,5(3 X, E 12.5)$

$-1 X$. TOTAL WASTE , T16,El2.5,5(3X,EI2.5))

WRI TE ( 2,2006$)$ COAL ( 34$),$ CHAR ( 34 ), OIL ( 34 ), TAR ( 34$),$ L IOUOR ( 34$),$ SREC ( 34 )

-, COAL ( 39 ), CHAR ( 39 ) , OIL (39) , TAR (39) , L I QUOR (39) , SREC (39),

-COAL (40), CHAR (40), ÓIL (40). TAR (40), L I QUOR (40), SREC (40)

2006 FORMAT ( $1 X$. WATER * T16,E12.5.5(3X, E12.5)

$-1 X .1 H *$ *PYRITIC SULFUR*,TIE,E12.5,5(3X,EI2.5)/

-IX, “CAREON*, TIS, EIC.5,5i3X,EIZ.5)/l

- IX, $1 \mathrm{H}^{*},-$-DOES NOT EQUAL 100 PERCENT BECAUSE. OF LOSS TO PFODUCT AND - IOR EFFLUENT GAS. $/ 11$

RETURN

END 


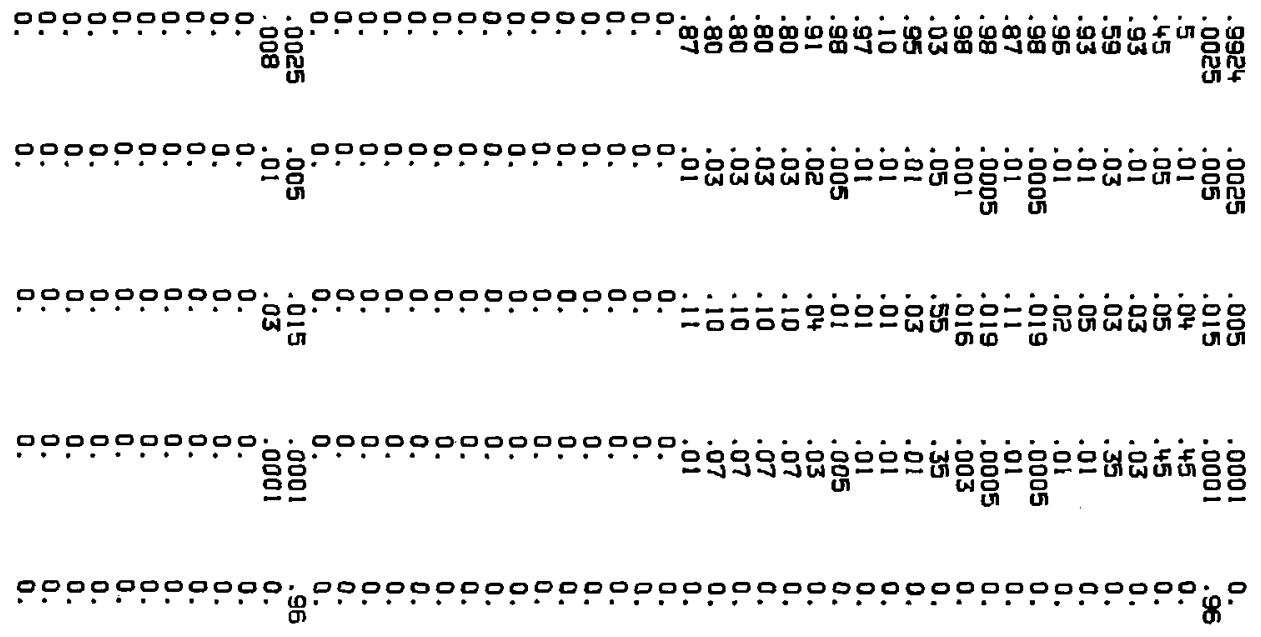


INPUT COAL:

$10000 E+06$

ELEMENT INPUT COAL ASH

\begin{tabular}{|c|c|}
\hline $\begin{array}{l}\text { ASH } \\
\text { 'SULFUR } \\
\text { ANTIMONY } \\
\text { ARSENIC } \\
\text { BERYLL IUM } \\
\text { CADMIUM } \\
\text { CHROMIUM } \\
\text { COPPER } \\
\text { IRON } \\
\text { LEAD } \\
\text { MAGNESIUM } \\
\text { MANGANESE } \\
\text { - MERCURY } \\
\text { NICKEL } \\
\text {-SELENIUH } \\
\text { SILVER } \\
\text { THALLIUM } \\
\text { ZINC } \\
\text { URANIUM } \\
\text { THORIUM-23E } \\
\text { RADIUM-226 } \\
\text { RADIUM-2Z2B } \\
\text { LEAD-2 IO } \\
\text { TOTAL WASTE } \\
\text { WATER } \\
\text { +PYRITIC SULFU } \\
\text { CARBON }\end{array}$ & $\begin{array}{l}.18700 E+05 \\
.30000 E+04 \\
.70000 E-01 \\
.27000 E+01 \\
.50000 E+00 \\
.12500 E+00 \\
.30000 E+01 \\
.11800 E+01 \\
.27000 E+04 \\
.11400 E+01 \\
.11800 E+03 \\
.74000 E+01 \\
.17000 E-01 \\
.20000 E+01 \\
.20000 E-01 \\
.10000 E-01 \\
.66000 E+00 \\
.16900 E+01 \\
.70000 E-01 \\
.66000 E+00 \\
.23660 E-07 \\
.26466 E-09 \\
.30590 E-09 \\
0 . \\
0 . \\
.18700 E+04 \\
.64100 E+05\end{array}$ \\
\hline
\end{tabular}

OtL

TAR

LIOUOR

SULFUR RECOVERY

$.18558 E+05$

$.75000 E+0$

(1L

$.46750 E+02$

$.15000 E+02$

35000E-01

$12150 E+01$

$46500 E+00$

$.70000 E-03$

$.13500 E+00$

$.50000 E-02$

$.37500 E-02$

$.30000 E-D !$

27900E+01

. $11328 E+01$

$.25460 E+04$

. $11800 E-0$ !

$.13500 E+01$

$.99180 E+00$

$.11564 E+03$

$.72520 E+01$

$.51000 E-03$

$.19000 E+01$

$.20000 E-02$

$.97000 E-02$

$.64680 E+00$

$.15379 E+01$

$.56000 E-01$

$.52800 E+00$

. $18928 E-07$

. $21173 E-09$

$.26613 E-09$

$.22894 E+05$

$.38156 E+04$

$.46750 E+01$

$11400 E-01$

$.59000 E-01$

$.74000 E-02$

$.85000 E-03$

$.20000 E-01$

.20000E-03

$.10000 E-03$

$.33000 E-02$

33800E-01

$.21000 E-02$

. [9800E-01

70980E-09

$.79398 E-11$

30590E- 11

$.10000 E+04$

$.12000 E+03$

$.93500 E+01$

$.51280 E+03$

$.64100 E+03$

$.93500 E+02$

$.45000 E+02$

. $28000 E-02$

$.13500 E+00$

15000E-01

$.37500 E-02$

$.15000 E+00$

$.23600 E-01$

$.51300 E+02$

$12540 E+00$

$.22420 E+01$

$.11840 E+00$

. 93500E-02

$.60000 E-01$

20000E-03

10000E-03

.66000E-02

$.67600 E-01$

.70000E-02

.66000E-01

. 23660E-08

. $26466 E-10$

$33649 E-10$

$.30000 E+04$

$.60000 E+03$

$.28050 E+02$

$.19230 \mathrm{E}+04$
$.18700 E+01$

$.30000 E+00$

31500E-01

. IE150E+01

$15000 E-01$

$.43750 E-01$

$.30000 E-01$

. 11800E-01

$.13500 E+01$

$11400 E-01$

$.59000 E-01$

.22200E-0I

59500E-02

$.20000 E-01$

.20000E-03

$.10000 E-03$

$.33000 E-02$

50700E-01

$.49000 E-02$

$.46200 E-01$

.16562E-08

$.18526 E-10$

30590E-11

$.15000 E+06$

$.14999 E+06$

$.18700 E+00$

$.64100 E+01$
0 .

0 .

0 .

0 .

0 .

0 .

0.

G.

0.

0.

0.

0 .

0.

0.

0.

0.

0.

0 .

0.

. 28800E+04

0 .

0 .

- -DOES NOT EOUAL 100 PERCENT gecause of loss to PRODUCt and/OR EFFLUENT Gas. 


\section{SOLID WASTE MODULE FOR THE SRC-II PROCESS COAL LIQUEFACTION}

\subsection{Introduction}

Currently there is a desire to become less dependent on ofl as an energy source and to rely more upon abundant domestlc coal supplies. Coal has the proven capability of being converted to a gas slutlar to natural gas, or it can serve as a direct source of energy via combustion. In the latter case, coal can be used in power plants to generate electricity; however, depending upon the type of coal used, there may be a large impact on the environnent, especially in terms of sulfur emissions. This in turn could incur high costs to the ut1lity companies for pollution control devices.

The solvent-refined coal (SRC-II) process described herein is a technology which can be used to convert coal to a liquid fuel. Since the main objective of SRC-II is to produce a low-sulfur ( $<1 \%)$ fuel which will minimize sulfur emissions when burned, usually only coals with falriy high sulfur contents are subject to this type of conversion. However, like any other coal technology, the SRC-II process has its own wastes which must be disposed of with as 1ittle effect on the environment as possible. To do this as efficiently and economically as possible the wastes must be determined as to both quantity and content.

\subsection{The SRC-II Process}

Coal conversion to liquid SRC is accomplished through a series of six basic steps and several types of supportive processes ${ }^{1}$. The six bastc steps (those used in the actual conversfon) are coal pretreatment, hydrogenation, phase (gas) separation, solids/liquid separation, fractionation, and hydrotreating. Supportive processes are generally elther by-product recovery, 
power generation, or waste treatment operations. These include solidiflcation, gas puriflcation, cryogenic separation, sulfur recovery, hydrogen generation, waste water treatment, and auxiliary facilities. See Figure 5.1 for the basic overall flow diagram of a typical SRC-II operation.

\section{SRC-II Process Description}

Coal Pretreatment. Coal pretreatment or preparation Includes all processes needed to change raw coal into a configuration acceptable to the 11quefaction operation. This includes coal recelving, storage, reclaining and cruhing, cleaning, drying, pulverizing, and slurry mixing.

Hydrogenation. The hydrogenation process consists of a slurry preheater and a hydrogen reactor. This is the actual 1iquefaction of the coal. Subsequent steps in the 11quefaction process refine the products made during hydrogenation.

Phase (Gas) Separation. The phase (gas) separation step Incluxies a number of separation techniques (high pressure separation, condensate separation, intermediate flashing, intermediate pressure condensate separation, low pressure condansate separation). In this step, the slurry from hydrogenation is divided into gaseous product and a solids/liquid stream. The output streams from this step are sent to gas purification, fractionation, and solids/11quid separation.

Solids/Liquid Separation. Here the solids/11quid (S/L) strean fron phase (gas) separation is divided into two separate streams: solid residue (sent to solidification) and liquid (sent to fractionation). 


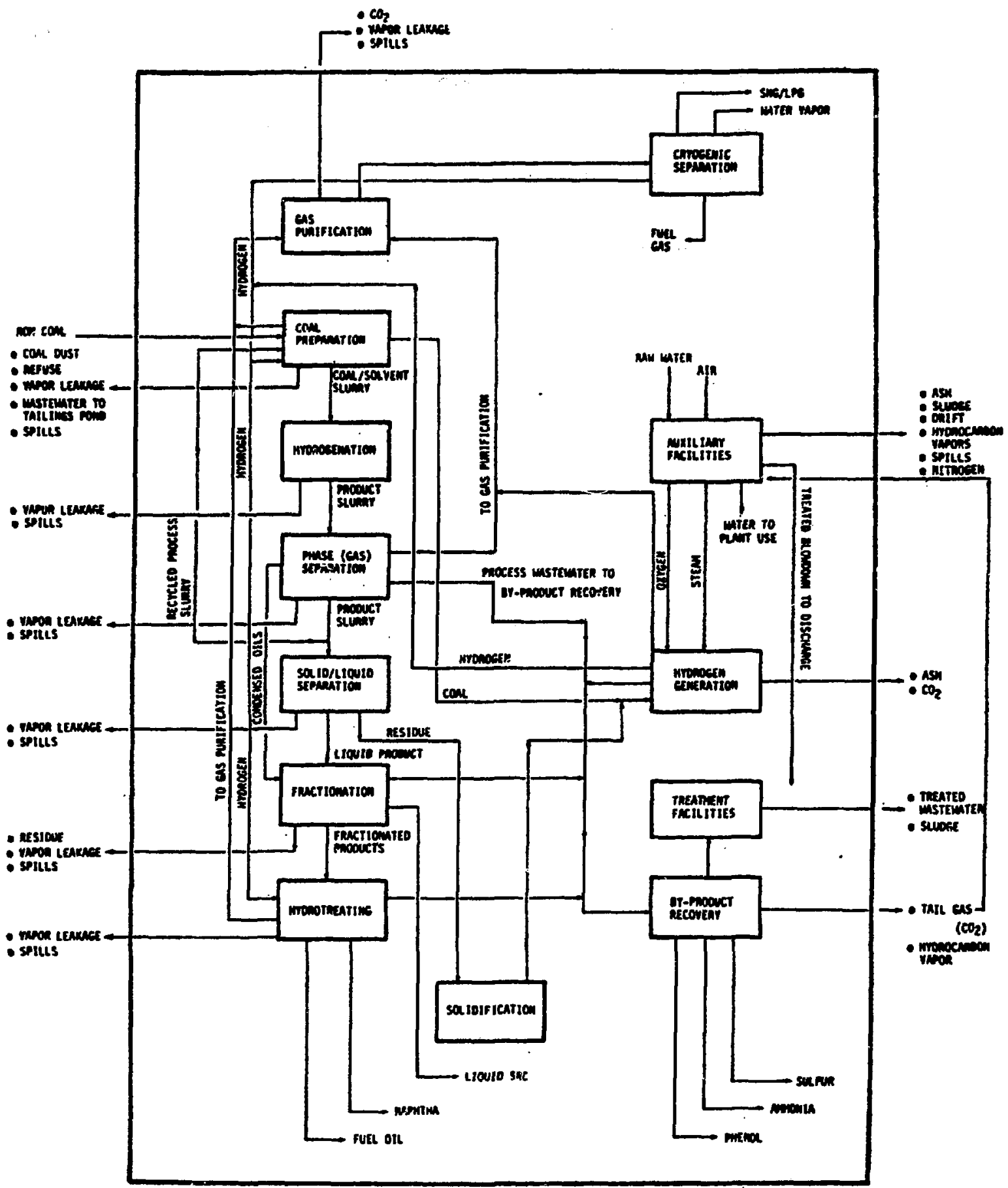

Figure 5.1 Flow diagram of a SRC-II Operation (Fron Reference 2) 
Fractionation. The 1Iquid stream from the previous separation step Is subject to a vacuum flash and atmospherlc distillation. This perforns three functions: (1) separation of the final SRC product from other 11quid fractions; (2) comíbination of light streams (fron S/L separation and phsse (gas) separation) Into light products (sent to hydrotreating); (3) recovery of wash solvent for recycling (to S/L gisparation).

Solvent Hydrotrenting. This process takes the 11ght products from fractionation and refines them to salable commerclal products, fuel ofl and naphtha. A pertion of these products are recycled for use in the liquefaction process .

\section{Supportive Processes}

Solldiflcation. Solidg from $S / L$ separation are croled and further solidified so that they are sultable for use in gastfication (hydrogen production). More solids are expected to be produced than are needed in gasiflcation, and this excess w11l be disposed of as a solid waste.

Gas Purification. Gases from phase (gas) separation, hydrotreating, and hydrogen generation are purlfled by acld gag removal. Purifled gases are sent to cryogenic separation for further purification.

Cryogenic Separation. Purified gas is taken from the preceding process and run through a serles of cryogenic unfts. Products resulting from this process Include synthetic natural gas, liquid petroleu gas, and light 0118 .

Sulfur Recovery. Actd gas from gas purification is converted to elemental sulfur In this process. 
Hydrogen Generation. Some of the solidified mineral residue from solidification is used to generate hydrogen via gasification. The hydrogen is needed to increase the hydrogen/carbon ratio to the proportion required produce 11quid fuels from coal: ${ }^{2}$ The gasifler feed may consist of mineral residue only, 3,4 residue and coal, $2,5,7$ or residue and o1 $1^{6}$.

Other Supportive Processes. Other processes which are needed, although they are not directly part of the liquefaction process, Include:

$\begin{array}{ll}\text { ammonia recovery } & \text { raw water treatment } \\ \text { phenol recovery } & \text { waste water treatment } \\ \text { oxygen generation } & \text { cooling towers } \\ \text { steam generation } & \text { power generation } \\ \text { product, by-product storage } & \end{array}$

\subsection{Solld Wastes from SRC-II Process}

Table 5.1 and Flgure 5.2 summarlze the sources and types of solid waste in SRC-II 11quefaction (and preferred control technology, Table 5.1).

\subsection{Assumptions Made in Modeling SRC-II Solid Wastes}

The solid waste streams which are quantified in this module are limited to two, mineral residue and gasifier slag. In addition, estimates are made of the composition of the sulfur by-product and SRC product streams. Solld wastes from other sources are not quantifted here (see individual solid waste descriptions).

The Input coal is assumed to have been already subject to pretreating (cleaning) at Level 1 (as defined in Section 1). Any higher level of cleaning is falrly redundant, as the liquefaction itself can be considered a 
Table 5.1

Sumary of Solld Mastes Control Technology

Applicability to SxC Syotem

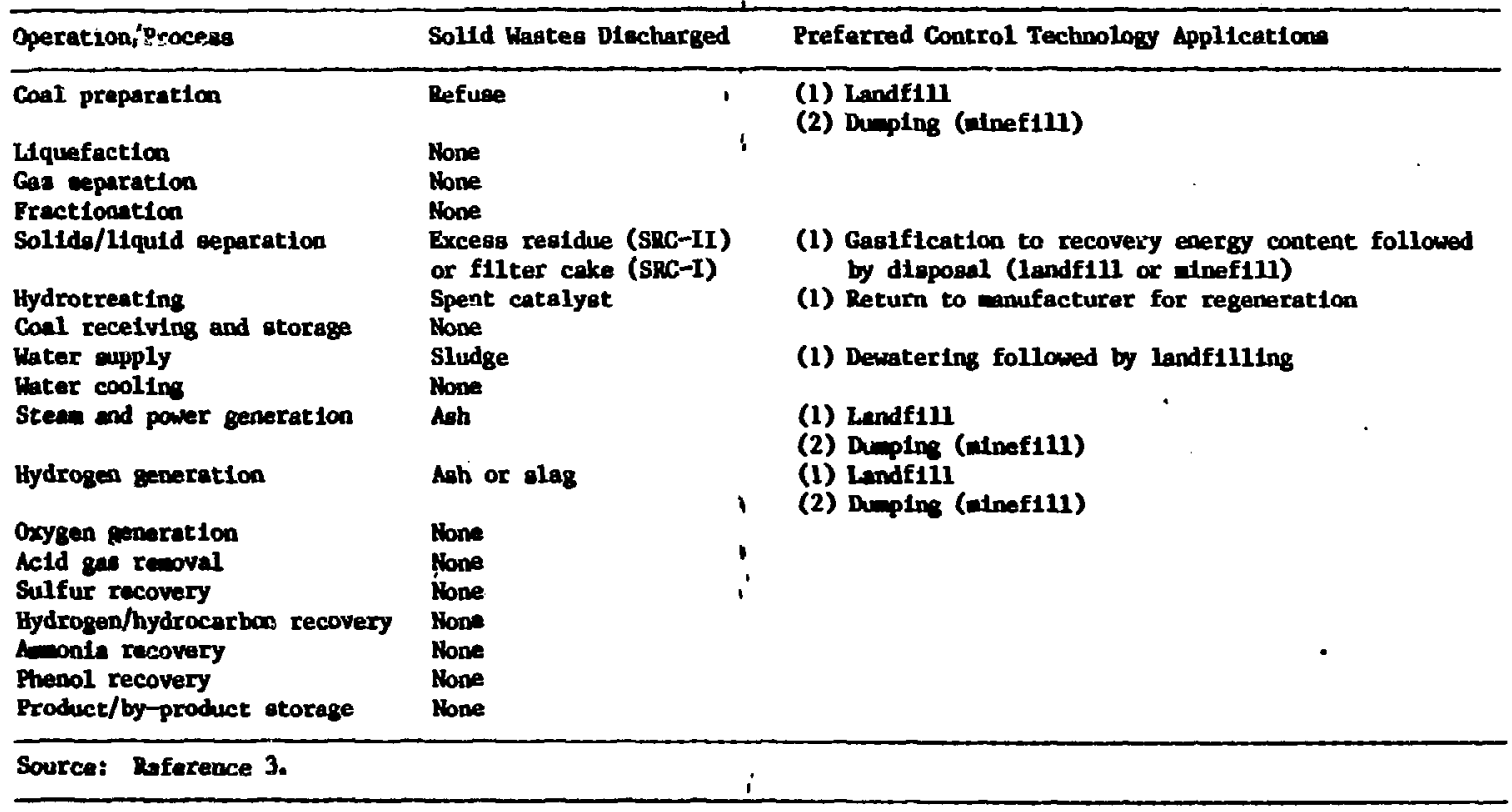


COAL RECEIVING ANO STORAGE

WATER
COOLING

OXYGEN GENERATION

SULFUR RECOVERY

HYDROGEN / HYDROCARBON

RECOVERY

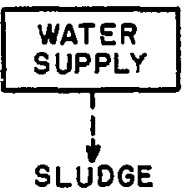

\section{STEAM AND}

POWER

GENERATION

T

ASH

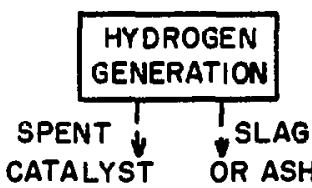

ACID GAS

REMOVAL

AMMONIA

RECOVERY

PHENOL

RECOVERY

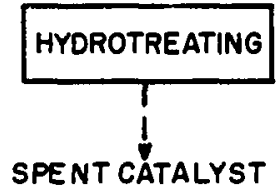

FRACTIONATION

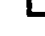

\section{SPENT CATALYST}

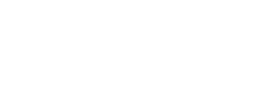

COAL CLEANING REFUSE

LIQUEFACTION
PRETREATMENT

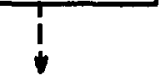
E
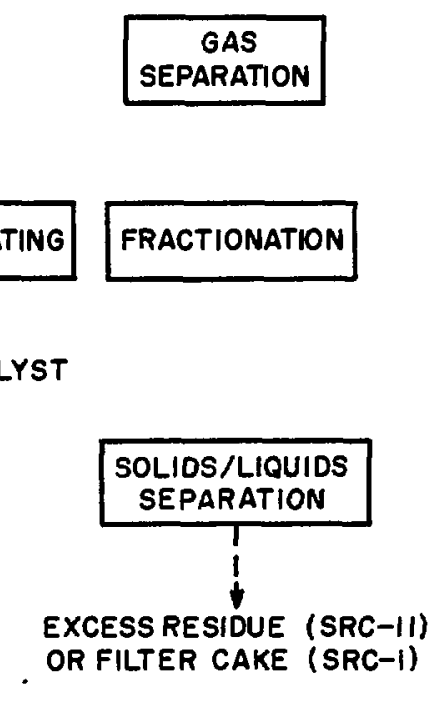

PRODUCT/BY - PRODUCT STORAGE

FIgure 5.2 Sources of Solld Waste in SRC Systems (From Reference 7) 
cleaning process. Part of the input coal is assumed to be sent directly to gasification, where it is combined with some of the mineral residue from the liquefaction process. This assumption requires no extra work for the module user; it is made because the trace metal data used herein are taken from Reference 7, which uses a residue/coal mixture in the gasifier. Failure to make the above assumption could therefore lead to trace metal mass balances greater than $100 \%$ due to the unaccounted input to the gasifier.

Since $100 \%$ mass balances may not, in reality, be obtained in the four output streams considered in this module (because of other waste and product streams), most elements have been normalized to achieve a $95 \%$ balance. While even this may be a large percentage, this assumption is made because (1) data for some elements led to mass balance greater than $100 \%$ and (2) elements lost to other streams may be partially compensated for by addition from other inputs (e.g., solvents, catalysts, water). 6 See Appendix 5B for the description of trace element balance calculation.

\subsection{Solid Wastes Not Quantified}

Coal Cleaning Refuse. Coal dust and leachate from coal piles are not quantified here. Wastes from coal cleaning can be estimated elsewhere (see Section 1).

Ash from Steam and Power Generation. Solid wastes from generation can be estimated elsewhere (Section 2).

Sludge from Water Treatment. The composition of sludge from raw and waste water treatment is almost as dependent on the water composition as on 
the coal. Since the water characteristics can vary widely from site to site, these sludges can not be modeled in as general a way as this module intends. Spent Catalysts from Hydrotreating and Hydrogen Generation. The 1ifetime of catalysts is inversely dependent upon operation time.9 Therefore, purging of spent catalysts will be an intermittent and site specific process. This and the facts that (1) there is a wide variety of catalysts that may be used in the SRC-II process, and (2) some catalysts are regenerable (and therefore will not contribute to solid waste) makes modeling of spent catalysts impossible in this module.

5.6 SRC-II Liquefaction Module Description

The SRC-T module assumes constant removas rates of each of the input trace elements for each of the streams quantified, that is, a constant fraction of the total input element will be retained in the mineral residue, etc. (these constants will necessarlly be different for each element and for each stream). Total quantities and major components of output streams are calculated as per Appendix 5A. The module is called with the following arguments :

1) total quantity of coal

2) input coal characteristics vector

3) output solld waste characteristics vectors

The input and output vectors each contain 50 elements, These elements are shown in Table 5.2. Since these vectors are constructed to be conformable to any of the solid waste modules which have been produced, there are presently some empty elements ( 48 to 50, not shown in Table 5.1) and some 


\begin{tabular}{|c|c|c|c|}
\hline & & $\begin{array}{l}\text { le } 5.2 \\
\text { ements }\end{array}$ & \\
\hline Number & Type & Number & Type \\
\hline 1 & Ash & 24 & Hydrocarbons \\
\hline 2 & Sulfur (S) & 25 & Total solld waste \\
\hline 3 & Antimony (Sb) & 26 & Unreacted 1imestone \\
\hline 4 & Arsentc (As) & 27 & Calcium sulfite \\
\hline 5 & Beryllfum (Be) & 28 & Calcium sulfate \\
\hline 6 & Cadmi um (Cd) & 29 & Soda ash \\
\hline 7 & Chromiun (Cr) & 30 & Magnesium sulfite \\
\hline 8 & Copper (Cu) & 31 & Magnesium oxide \\
\hline 9 & Iron $(\mathrm{Fe})$ & 32 & Sodium bisulfite \\
\hline 10 & Lead $(\mathrm{Pb})$ & 33 & Sodium sulfite \\
\hline 11 & Maguesium (Mg) & 34 & Water \\
\hline 12 & Manganese $\left(M_{n}\right)$ & 35 & Sulfur dioxide \\
\hline 13 & Mercury（Hg） & 36 & Nitrous oxides \\
\hline 14 & Nickel (Ni) & $: 7$ & Carbon monoxide \\
\hline 15 & Selenium (Se) & 38 & Methane \\
\hline 16 & S1lver (Ag) & 39 & Pyritic sulfur \\
\hline 17 & Thallium (T1) & 40 & Carbon \\
\hline 18 & Zinc $(\mathrm{Zn})$ & 41 & Btu \\
\hline 19 & Uranium-238 (U) & 42 & Carbon dioxide \\
\hline 20 & Thorium-232 (Th) & 43 & Sodium blcarbonate \\
\hline 21 & Radium-226 (Ra) & 44 & Sodium carbonate \\
\hline 22 & Radium-228（Ra） & 45 & Sodium Sulfate \\
\hline \multirow[t]{2}{*}{23} & Lead-210 ( $\mathrm{Pb})$ & 46 & Calcium carbonate \\
\hline & & 47 & Calcium oxide \\
\hline
\end{tabular}


elements which are not applicable to this module, and as such are disregarded (set to 0 ) in the output vectors and omitted in the output printout.

Table 5.3 gives the coefficients which determine the amount of each trace element that goes to each solid waste stream.

Table 5.4 gives the equations which determine the total quantity of each stream and their major components (water, ash, sulfur and carbon).

It should be noted here that, given the data, some of these coefficients are little more than conjecture as to the "true" removal rates. Acquisition of more and better data is definitely indicated as a need for the future.

The appendices indicate how the choice of coeffictents was made. Also in the appendices is more information on the computer module.

Table 5.3

\begin{tabular}{llccc} 
Fractions (Coefficients) of Array & Elements & Going & to Solid Waste Streams \\
\hline Element & $\begin{array}{c}\text { Mineral } \\
\text { Residue }\end{array}$ & $\begin{array}{c}\text { Gasifier } \\
\text { Slag }\end{array}$ & $\begin{array}{c}\text { Recovered } \\
\text { Sulfur }\end{array}$ & $\begin{array}{c}\text { SRC } \\
\text { Product }\end{array}$ \\
\hline $\mathrm{Sb}$ & 0.728 & 0.219 & 0.002 & 0.001 \\
$\mathrm{As}$ & 0.842 & 0.102 & 0.003 & 0.003 \\
$\mathrm{Be}$ & 0.749 & 0.198 & 0.001 & 0.002 \\
$\mathrm{Cd}$ & 0.846 & 0.101 & 0.001 & 0.002 \\
$\mathrm{Cr}$ & 0.466 & 0.214 & 0.007 & 0.263 \\
$\mathrm{Cu}$ & 0.749 & 0.198 & 0.001 & 0.002 \\
$\mathrm{Fe}$ & 0.846 & 0.101 & 0.001 & 0.002 \\
$\mathrm{~Pb}$ & 0.846 & 0.101 & 0.001 & 0.002 \\
$\mathrm{Mg}$ & 0.793 & 0.154 & 0.002 & 0.001 \\
$\mathrm{Mn}$ & 0.731 & 0.206 & 0.008 & 0.005 \\
$\mathrm{Hg}$ & 0.018 & 0.008 & 0.081 & 0.003 \\
$\mathrm{Ni}$ & 0.466 & 0.214 & 0.007 & 0.263 \\
$\mathrm{Se}$ & 0.838 & 0.092 & 0.019 & 0.001 \\
$\mathrm{Ag}$ & 0.846 & 0.101 & 0.001 & 0.002 \\
$\mathrm{Tl}$ & 0.846 & 0.101 & 0.001 & 0.002 \\
$\mathrm{Zn}$ & 0.731 & 0.206 & 0.008 & 0.005 \\
$\mathrm{U}$ & 0.793 & 0.154 & 0.002 & 0.001 \\
$\mathrm{Th}$ & 0.793 & 0.154 & 0.002 & 0.001 \\
$\mathrm{Ra} 226$ & 0.846 & 0.101 & 0.001 & 0.002 \\
$\mathrm{Ra} 228$ & 0.846 & 0.101 & 0.001 & 0.002 \\
$\mathrm{~Pb} 210$ & 0.846 & 0.101 & 0.001 & 0.002 \\
\hline
\end{tabular}


Table 5.4

Determination of Total Output and Major Components

\begin{tabular}{|c|c|c|c|c|}
\hline Component & $\begin{array}{l}\text { Mineral } \\
\text { Restdue }\end{array}$ & $\begin{array}{l}\text { Cesifier } \\
\text { Slag }\end{array}$ & $\begin{array}{l}\text { Recovered } \\
\text { Sulfur }\end{array}$ & $\begin{array}{c}\text { SRC } \\
\text { Product }\end{array}$ \\
\hline Total quantity & $0.2 I_{c}$ & $0.083 I_{c}$ & $I_{s}-0.007 Q_{s r c}$ & 0.3 \\
\hline Sulfur & $0.02\left(I_{s}-0.007 \quad Q_{s r c}\right)$ & $0.0:\left(I_{s}-0.007 Q_{\text {src }}\right)$ & $0.95\left(I_{s}-0.007 Q_{s r c}\right)$ & 0.00 \\
\hline Ash & $0.75\left(I_{a}-0.0015 O_{\text {src }}\right)$ & $0.25\left(I_{\mathrm{a}}-0.0015 \mathrm{O}_{\mathrm{src}}\right)$ & - & 0.00 \\
\hline Water & - & $0.4 \mathrm{O}_{\mathrm{g}}$ & - & \\
\hline Carbon & $0.28 o_{r}$ & $0.001 \mathrm{og}_{\mathrm{g}}$ & - & 0.87 \\
\hline \multicolumn{5}{|c|}{$\begin{aligned} \mathrm{I}_{\mathrm{X}} & =\text { total input amount of substance } \mathrm{x} \\
\mathrm{O}_{\mathrm{X}} & =\text { total output amount of substance } \mathrm{x} \\
\mathrm{C} & =\text { coal. } \\
\text { src } & =\text { SRC product. } \\
\mathrm{r} & =\text { mineral residue. } \\
\mathrm{g} & =\text { gasifier slag. } \\
\mathrm{a} & =\text { ash. } \\
\mathrm{s} & =\text { sulfur. } \\
- & =\text { indicates zero amount contained. }\end{aligned}$} \\
\hline
\end{tabular}




\section{REFERENCES}

1. Fred C. Hart Assoc., Inc., The Impact of RCRA on the Commercialization of Coal Liquefaction Processes, prepared for U.S. DOE, Nov. 1979.

2. U.S. Environmental Protection Agency, Standards of Practice Manual for the Solvent Refined Coal Liquefaction Process, EPA-600/7-78-091, June 1978.

3. K.J. Shields, Environmental assessment report: Solvent-refined coal, Symp. Procs.: Environ. Aspects Fuel Conversion Technol. III, EPA-600/ 7-79-217, Sept. 1979.

4. C.R. Moxley, and D.K. Schmalzer, "Environmental Assessment of SRC-II - an Update", in Symp. Procs.: Environ. Aspects Fuel Conversion Technol. III, EPA-600/7-79-217, Sept. 1979 .

5. U.S. Environmental Protection Agency, Coal Conversion Control Technology Vol. II: Gaseous Emissions; Solid Wastes, EPA-600/7-79-228b, 0ct. 1979.

6. C.E. Jahnig, Evaluation of Pollution Control in Fossil Fuel Conversion Processes. Liquefaction; Section 2. SRC Process, EPA-650/2-74-009f, Mar. 1975.

7. U.S. Environmental Protection Agency, Environmental Assessment Report: Solvent Refined Coal (SRC) Systems, EPA-600/7-79-146, June 1979.

8. J.B. O'Hara, S.N. Rippee, B.I. Loran, anci W.J. Mindheim, "Environmental factors in coal liquefaction plant design", in Symp. Procs.: Environmental Aspects of Fuel Conversion Technology, EPA-650/2-74-118, Oct. 1974.

9. Oak Ridge National Laboratory, Environmental, Health, and Control Aspects of Coal Converston: An Information Overview, ORNL/EIS-94, Apr. 1977.

10. P.A. Dauzvardis, C.D. Brown, R.W. Hamllton, and L.J. Habegger, Environmental and Technical Aspects of the Utilization of SRC, AFB, and Low-Btu Coal Gasification in Industrial Processes, ANL Technical Memo, ANL/EES-TM-49, Oct. 1978.

11. U.S. Environmental Protection Agency, Environmental Assessment Data Base for Coal Liquefaction Technology. Vol. I. Systems for 14 Liquefaction Processes, EPA-600/7-78-184a, Sept. 1978.

12. P.D. Moskowitz, S.C. Morris, and A.S. Albanese, The global carbon dioxide problem: Impacts of U.S. synthetic fuel- and coal-fired electricity generating plants, J. A1r Poll. Cont. Assoc., Vol. 30, No. 4, Apr. 1980.

13) G.N. Reddy, Burning of Solvent Refined Coal: A Viable Means of Compliance, Argonne National Laboratory, CoNF-7810110-1, Oct. 1978. 


\section{APPENDIX 5A}

\section{DETERMINATION OF OUTPUT STREAM CHARACTERISTICS:}

TOTAL QUANTITY, WATER, CARBON, SULFUR, ASH

\section{A.1 SRC Product}

The total amount of SRC product seems to be fairly consistent relative to the amount of input (clean) coal, regardless of the coal characteristics:

\begin{tabular}{cccr}
$\begin{array}{c}\text { Quantity } \\
\text { Input Coal }\end{array}$ & $\begin{array}{c}\text { Quantity } \\
\text { SRC Product }\end{array}$ & Ratio & $\begin{array}{r}\text { Source } \\
\text { (Ref.) }\end{array}$ \\
\cline { 2 - 3 } 20,408 & 6,080 & 0.2978 & 2 \\
833,333 & 242,917 & 0.2915 & 8 \\
10,000 & 2,920 & 0.2920 & 10
\end{tabular}

(Note: while units of measure may vary from source to source, the number of interest is the ratio, which is dimensionless. Therefore, the units involved will be disregarded.) The total product quantity will be assumed to be $30 \%$ of the quantity of input coal.

Similarly, the ash and sulfur contents of SRC product seem to be generally uniform regardless of the amounts contained in the input coai ${ }^{9}$. The ash content is in the range of .1 to $.2 \%, 9-11,13$ and sulfur content ranges from as low as $.2 \%$ to $1 \%, 10$ with most estimates being from .5 to $.8 \% 6,10,11,15$ Therefore, the amounts of ash and sulfur, respectively, will be assumed to be $.15 \%$ and $.7 \%$ of the amount of SRC product.

Carbon content of the SRC product also seems constant, at about $87 \%$ of the total product ${ }^{2}$. It will be assumed that there is no water contained in the product.

\section{A. 2 Recovered Sulfur}

Most of the sulfur in the input coal is recovered from acid gases which are created during liquefaction and hydrogen generation ${ }^{6}$. Recovered sulfur 
w111 be assumed to be equal to $95 \%$ of the sulfur not retained in the SRC product. of the remaining $5 \%, 2 \%$ is assumed lost to other (unquantified) streams and the other $3 \%$ is assumed to be retained in the mineral residue and gasifier slag.

Since there are no aval'able data on recovered sulfur content of carbon, ash, and water, these copponents will be assumed to be nonexistent in the recovered sulfur. However, there may be some (falrly large) quantities of trace elements in the recovered sulfur ${ }^{7}$. Therefore, the total stream quantity is assumed to consist of sulfur ( $95 \%$ ) and other elements (some of which are quantified in Appendix 5B).

While inorganic (pyritic) sulfur may not follow the same paths as organic sulfur in the liquefaction process, 10 because of lack of avallable data both forms of sulfur are assuned to be similarly distributed.

\section{A. 3 Excess Mineral Residue}

Of the total residue created in the SRC-II process, approximately $75 \%$ is excess (not directed to gasification for hydrogen generation 2,7 ). This excess is approximately equal to $20 \%$ of the total input (clean) coal.

$\begin{array}{cccc}\begin{array}{c}\text { Quantity } \\ \text { Input Coal }\end{array} & \begin{array}{c}\text { Quantity } \\ \text { Excess M.R. }\end{array} & \text { Ratio } & \begin{array}{c}\text { Source } \\ \text { (Ref.) }\end{array} \\ & 4,075 & 0.1997 & 2 \\ 19,994 & 4,203 & 0.2102 & 7\end{array}$

The carbon content is about $28 \% 7$ Since the residue has been solidified, water content is assumed to be 0 .

Although there are no available data on the ash and sulfur content of the residue, most of what is not in the SRC product or recovered sulfur is 
expected to be retained in the resldue. Therefore, $75 \%$ of the ash and $2 \%$ of the sulfur not retalned in the S?C product are assumed to be in the residue.

\section{A. 4 Gasifier Slag}

The amount and character of gasifler slag is dependent on factors which may vary widely from site to site, such as gasifier feed composition and type of gasification process. However, some generalizations can be made about the resulting slag.

(1) Total (dry) slag can be estimated as about $5 \%$ of the input coal:

\begin{tabular}{cccc}
$\begin{array}{c}\text { Quantity } \\
\text { Input Coal }\end{array}$ & $\begin{array}{c}\text { Quantity } \\
\text { Gasifier Slag }\end{array}$ & Ratio & $\begin{array}{c}\text { Source } \\
\text { (Ref.) }\end{array}$ \\
\cline { 5 - 5 } 20,408 & 1015.2 & 0.0497 & 2 \\
20,000 & 1197.0 & 0.0599 & 5 \\
19,944 & 922.8 & 0.0463 & 7 \\
833,333 & 59400.0 & 0.0713 & 6
\end{tabular}

(2) The water:dry slag ratio is about $2: 3,2,7$

(3) Carbon. is assumed to be a minor constituent (.1\% of total dry slag) In the stream.

(4) While no data are available, ash and sulfur content can be assumed to be $25 \%$ (ash) and $1 \%$ (sulfur) of the respective total input amount which 1 s not retained in the SRC product. 
APPENDIX 5B

DETERMINATION OF OUTPUT STREAM CHARACTERISTICS: TRACE METALS

\section{B. 1 General Discussion}

There is a large void that needs to be filled in the realm of trace metal content of 1iquefaction output streams. Lack of complete and consistent data makes quantification of trace metal distribution an almost insurmountable task.

Reference 7 was the only source which contained enough data to estimate most trace metals for all output streams considered in this module. However, some of these data were estimates, rather than actual measured quantities. Several trace elements ( $\mathrm{Sb}, \mathrm{Fe}, \mathrm{Pb}, \mathrm{U}, \mathrm{Th}$ ) attained mass balances greater than $100 \%$ in the four streams considered; others (e.g., Ni) had a large fraction unaccounted for. This over or under account of elements can be attributed to estimation techniques (for those not based on actual measurements), error in input coal and output stream measurements, loss of elements to other streams, and addition of elements from other sources.

The assumption was made to normalize all trace elements except mercury to $95 \%$ of their input total, which allows for loss to other liquefaction output streams. Mercury is assumed to be largely lost in gaseous emissions because of its high volatility. 7 Elements for which there were only partial data were compared to other elements with complete data for distributional similarities, and the missing values were assumed to be the same as those of the similar element. Some elements which hsd missing data were treated on an individual bas1s. 
5B.2 Trace Elements in Output Streams

Reference 7 is the basis for trace metal distributions. Estimations are based on the following quantities:

$Q=$ total Input coal: $19944 \mathrm{Mg} /$ day -

$m=$ total excess mineral residue: $4203 \mathrm{Mg} / \mathrm{day}-$

$g=$ total gasifier slag: $922.8 \mathrm{Mg} /$ day -

$r=$ total recovered sulfur: $443 \mathrm{Mg} /$ day -

The trace element content of the "average U.S. coal" used is shown in table 5B.1. This coal was used as a basis for estimating the trace components

Table 5B. 1

Trace Element Content of "Average U.S. Coal"

\begin{tabular}{lrrccc}
\hline Element & $\begin{array}{c}\text { Conc. } \\
(\mathrm{ppm})\end{array}$ & $\begin{array}{c}\text { Total } \\
\text { Quantity } \\
\text { (Tons)* }\end{array}$ & Element & $\begin{array}{c}\text { Conc. } \\
\text { (ppm). }\end{array}$ & $\begin{array}{c}\text { Total } \\
\text { Quantity } \\
\text { (Tons)* }\end{array}$ \\
\hline $\mathrm{Sb}$ & 2.2 & 0.044 & $\mathrm{Hg}$ & 0.15 & 0.003 \\
$\mathrm{As}$ & 10.9 & 0.217 & $\mathrm{Ni}$ & 19.0 & 0.379 \\
$\mathrm{Be}$ & 1.4 & 0.028 & $\mathrm{Se}$ & 4.0 & 0.080 \\
$\mathrm{Cd}$ & 3.4 & 0.068 & $\mathrm{Ag}$ & 0.17 & 0.003 \\
$\mathrm{Cr}$ & 16.3 & 0.325 & $\mathrm{TI}$ & 0.66 & 0.013 \\
$\mathrm{Cu}$ & 12.7 & 0.253 & $\mathrm{Zn}$ & 120.0 & 2.393 \\
$\mathrm{Fe}$ & $14,800.0$ & 295.171 & $\mathrm{U}$ & 2.2 & 0.044 \\
$\mathrm{~Pb}$ & 13.0 & 0.259 & $\mathrm{Th}$ & 4.5 & 0.09 \\
$\mathrm{Mg}$ & 1120.0 & 22.337 & $\mathrm{Ra}$ & - & - \\
$\mathrm{Mn}$ & 36.0 & 0.718 & & & \\
\hline
\end{tabular}

Source: Reference 7, p. 175.

- Indicates data not avallable.

* Based on 19,944 tons of input coal.

of sulfur, SRC product, and slag. Partitioning factors (see below) were used to estimate trace elements in the mineral residue. 
Trace Metals in Mineral Residue. Estimated partitioning factors (Reference 7, p. 255) were given for the amount of trace elements in the mineral residue. The partitioning factor for each element, is defined as:

$$
\frac{c_{s}}{c_{1}}
$$

where,

$$
\begin{aligned}
& C_{x}=\text { the concentration of element } C \text { in stream } x, \\
& s=\text { the output stream, } \\
& i=\text { the input coal stream. }
\end{aligned}
$$

Since the total amount of an element in any stream $x$ is

$$
c_{\mathbf{x}} \cdot t_{\mathbf{x}}
$$

where $t_{x}=$ total quantity of stream $x$, then the proportion of that element which is retained in stream $x$ is

$$
\frac{c_{x} \cdot t_{x}}{c_{1} \cdot t_{i}}=\frac{c_{x} \cdot t_{x}}{c_{i} \cdot q} .
$$

This is simply the partitioning factor multiplied by the ratio of the output stream to the amount, $Q$, of input coal. In estimating the trace content of the residue, the minimum partitioning factors were used, as the average and maximum factors gave results that were greater than unity (i.e., a trace mass balance $>100 \%$. - Even for the minimum factors, this occurred for two elements ( $\mathrm{Pb}$ and $\mathrm{U}$ ). Table 5B.2 gives the partitioning factors used and the mass proportion of elements retained in the residue.

Trace Metals in Other Output Streams. Trace content of other output streams is based upon either estimated (slag, sulfur) or measured (SRC product) concentrations. The proportions of the input elements captured in 
Table 5B.2

Partitioning Factors and Proportion of Total Trace Elements Retained in Mineral Residue

\begin{tabular}{lccccc}
\hline Element & $\begin{array}{c}\text { Partitioning } \\
\text { Factor* }\end{array}$ & $\begin{array}{c}\text { Proportion } \\
\text { Retained** }\end{array}$ & Element & $\begin{array}{c}\text { Partitioning } \\
\text { Factor* }\end{array}$ & $\begin{array}{c}\text { Proportion } \\
\text { Retained** }\end{array}$ \\
\hline $\mathrm{Sb}$ & 4.3 & 0.906 & $\mathrm{Hg}$ & 0.031 & 0.007 \\
$\mathrm{As}$ & 4.0 & 0.843 & $\mathrm{Ni}$ & 0.4 & 0.084 \\
$\mathrm{Be}$ & 2.0 & 0.421 & $\mathrm{Se}$ & 3.6 & 0.759 \\
$\mathrm{Cd}$ & 1.6 & 0.337 & $\mathrm{Ag}$ & - & - \\
$\mathrm{Cr}$ & 1.0 & 0.211 & $\mathrm{Tl}$ & - & - \\
$\mathrm{Cu}$ & 2.1 & 0.443 & $\mathrm{Zn}$ & 2.0 & 0.421 \\
$\mathrm{Fe}$ & 4.6 & 0.969 & $\mathrm{U}$ & 6.6 & 1.391 \\
$\mathrm{~Pb}$ & 5.2 & 1.096 & $\mathrm{Th}$ & 4.52 & 0.953 \\
$\mathrm{Mg}$ & 4.5 & 0.948 & $\mathrm{Ra}$ & - & - \\
$\mathrm{Mn}$ & 2.1 & 0.443 & & & \\
\hline
\end{tabular}

Source: Reference 7, p. 255

- Indicates data not avaflable.

* Minimum.

** Based on total proportion (Table 5B.1) and 4203:19944 residue to coal ratio.

these three streams are based on the total quantities of the streams as given above. The concentrations and proportions are shown in Table 5B.3.

5B.3 Frace Element Distribution Used in SRC-II Module

As mentioned above, no trace element achieved a $100 \%$ mass balance over the four output streams. Some elements had mass balances greater than $100 \%$ others has less than $50 \%$ of the input amount accounted for. Some elements have missing data (partial or all).

Elements Having Complete Sets of Data. Elements with complete sets of data were normalized to have $95 \%$ of the input amount of that element accounted for, as explained above. This was accomplished by multiplying each of the four proportions by the normalization factor $\mathbb{N}$, 


\begin{tabular}{|c|c|c|c|c|c|c|}
\hline \multirow[b]{2}{*}{ Element } & \multicolumn{5}{|c|}{$\begin{array}{c}\text { Table 5B. } 3 \\
\text { Trace Elements in Slag, Recovered } \\
\text { Sulfur, and SRC Product }\end{array}$} & \multirow[b]{2}{*}{$\begin{array}{l}\text { Product } \\
\text { Proportion }\end{array}$} \\
\hline & \multicolumn{2}{|c|}{$\begin{array}{l}\text { Gastifier Slag } \\
\text { Conc.* Proportion** }\end{array}$} & \multicolumn{2}{|c|}{$\begin{array}{c}\text { Recovered Sulfur } \\
\text { Conc.* Proportion** }\end{array}$} & $\begin{array}{r}\text { SRC } \\
\text { Conc. * } \\
\end{array}$ & \\
\hline $\mathrm{Sb}$ & 13.0 & 0.273 & 0.2 & 0.002 & 0.003 & 0.001 \\
\hline As & 24.0 & 0.102 & 1.7 & 0.003 & 0.006 & 0.003 \\
\hline $\mathrm{Be}$ & - & - & - & - & 0.003 & 0.001 \\
\hline Cd & - & - & - & - & 0.024 & - \\
\hline $\mathrm{Cr}_{\mathbf{r}}$ & 34.0 & 0.097 & 2.4 & 0.003 & 2.5 & 0.119 \\
\hline $\mathrm{Cu}$ & 32.0 & 0.117 & 0.64 & 0.001 & 0.100 & 0.001 \\
\hline $\mathrm{Fe}$ & 37000.0 & 0.116 & 740.0 & 0.001 & 62.0 & 0.002 \\
\hline $\mathrm{Pb}$ & 20.0 & 0.071 & - & - & 0.007 & 0.001 \\
\hline $\mathrm{Mg}$ & - & - & 290.0 & 0.006 & 2.1 & 0.001 \\
\hline Mn & 97.0 & 0.125 & 8.6 & 0.005 & 0.790 & 0.003 \\
\hline $\mathrm{Hg}$ & 0.0093 & 0.003 & 0.21 & 0.031 & - & - \\
\hline $\mathbf{N} \mathbf{1}$ & 42.0 & 0.102 & - & - & 0.160 & 0.006 \\
\hline Se & 7.2 & 0.083 & 3.0 & 0.017 & 0.003 & 0.001 \\
\hline $\mathrm{Ag}$ & - & - & - & - & - & - \\
\hline T1 & - & - & - & - & 0.007 & 0.005 \\
\hline $\mathbf{Z n}$ & 180.0 & 0.069 & - & - & 0.100 & 0.005 \\
\hline $\mathrm{U}$ & - & - & - & - & 0.007 & 0.001 \\
\hline Th & 18.0 & 0.185 & 0.45 & 0.002 & 0.006 & 0.001 \\
\hline $\mathrm{Ra}$ & - & - & - & - & - & - \\
\hline
\end{tabular}

Source: Reference 7.

- Indicates data not available.

* All concentrations in ppm (wt.).

** Proportion of total element retained in stream.

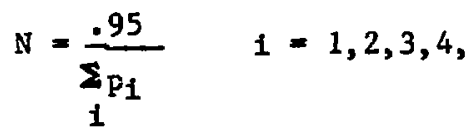

where the $\mathrm{p}_{1}$ are the calculated proportions of the element in the four streams (from Tables 5B.2 and 5B.3).

Elements with complete data are $\mathrm{Sb}, \mathrm{As}, \mathrm{Cr}, \mathrm{Cu}, \mathrm{Fe}, \mathrm{Mn}, \mathrm{Se}$, and Th. The final distribution (after normalization) decided upon for these elements i,s given In Table 5B.3. 
Elements with One or Two Missing Values. Elements with one or two missing values (except $\mathrm{Hg}$, see below) were compared to elements with complete sets of data. If the distribution of the element with missing data seemed similar to one of the other elements, the former was assigned that complete distribution.

Elements with one or two missing data points and the comparable elements are

$\begin{array}{cc}\text { Missing Data } & \text { Complete Data } \\ & \mathrm{Cu} \\ \mathrm{Pb} & \mathrm{Fe} \\ \mathrm{Mg} & \mathrm{Th} \\ \mathrm{N1} & \mathrm{Cr} \\ \mathrm{Zn} & \mathrm{Mn} \\ \mathrm{U} & \mathrm{Th}\end{array}$

Other Elements. Elements which have not been accounted for up until now include $\mathrm{Cd}, \mathrm{Hg}, \mathrm{Ag}, \mathrm{Tl}$, and $\mathrm{Ra}$. These are assumed to be distributed as follows:

Hg is given an SRC product proportion of .001. It is then normalized to $11 \%$ of its input amount ( $89 \%$ unaccounted for ${ }^{7}$ ).

$\mathrm{Cd}, \mathrm{Ag}, \mathrm{Tl}$, $\mathrm{Ra}$ are assigned the Fe distribution under the assumption that they are retained mostly in the residue (as are most trace element $s^{0}, 1^{10}$ ) The final proportional distribution of all trace elements are given in Table 5B. 3. 
APPENDIX 5C

DESCRIPTION OF COMPUTER MODULE

The SRC-II liquefaction solid waste module consists of one subroutine and a data file containing the fraction of the input components that are removed to the solid waste. The module is set into motion by a call to SRC-II:

Call SRCII ( $Q$, COAL, MRES, SLAG, SUL, SRC)

where

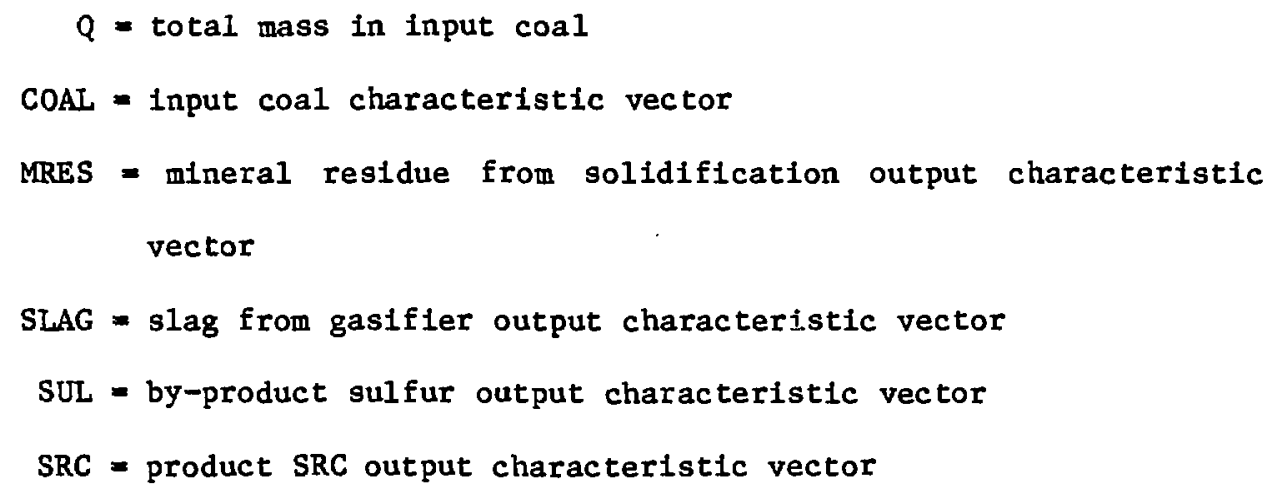

The subroutine first calculates the radium and lead-210 input quantities from the input uranium-238 and thorlum-232 quantitles if the former have not been supplied. See Section 7 for calculations of these quantities.

The subroutine calculates the characteristics of each output stream and prints them out (see Appendix 5D for sample output). The data file contains the coefficlents of all elements that are removed at a constant rate and can be calculated by a simple multiplication. All elements in the input vector that are empty, are not applicable to this module, or are calculated other than by a single multiplication (e.g., sulfur, ash) have corresponding coefficient of zero. 
All calculations (iñsluding empty and nonapplicable elements) are done through DO loops in the module. The water, ash, sulfur, carbon, and total solid waste elements are calculated separately.

The module prints out the input coal and output vectors (applicable elements only). If this printout is not desired at some future time, the printout section can simply be removed with no effect on the solid waste calculations. All vectors are returned to the calling program intact, including the input coal characteristics.

The data file is presently read in as "TAPEl". 


\section{APPENDIX 5D \\ COMPUTER CODE AND SAMPLE OUTPUT}

This section sets out the computer code used for the SRC-II liquefaction module and the data file of coefficients, with a sample input and the resulting output. Table 5D.1 gives the coal characteristics used as input. The quantity of coal (Q) in the input is 100,000 tons.

At present the main program of the code is used only to set the input variables.

Table 5D.1

Input Characteristics of Coal

\begin{tabular}{lc}
\hline Element & Input Quantity (tons) \\
\hline Ash & 18700.00 \\
Sulfur & 3000.00 \\
Antimony & 0.07 \\
Arsenic & 2.70 \\
Beryllium & 0.50 \\
Cadmium & 0.125 \\
Chromium & 3.00 \\
Copper & 1.18 \\
Iron & 2700.00 \\
Lead & 1.14 \\
Magnesium & 118.00 \\
Manganese & 7.40 \\
Mercury & 0.017 \\
Nickel & 2.00 \\
Selenium & 0.02 \\
Silver & 0.01 \\
Thallium & 0.66 \\
Zinc & 1.69 \\
Uranium & 0.07 \\
Thorium & 0.66 \\
Pyritic sulfur & 1870.00 \\
Carbon & 64100.00 \\
Btu & $2.3 \times 10^{12}$ \\
\hline
\end{tabular}


PROGRAM CLL (TAPE1, OUTPUT, TAPE2=OUTPUT) OIMENSION COAL (5O)

REAL MRES (50), SLAG (50), SUL (50), SRC (50) $Q=100000$

$\operatorname{COAL}(1)=18700$.

$\operatorname{COAL}(2)=3000$.

$\operatorname{COAL}(3)=.07$

$\operatorname{COAL}(4)=2.7$

$\operatorname{COAL}(5)=.5$

$\operatorname{COAL}(6)=.125$

$\operatorname{COAL}(7)=3$.

$\operatorname{COAL}(\theta)=1.18$

$\operatorname{COAL}(9)=2700$

$\operatorname{COAL}(10)=1,14$

COAL $(11)=118$.

$\operatorname{COAL}(12)=7.4$

$\operatorname{COAL}(13)=.017$

$\operatorname{COAL}(14) \times 2$.

$\operatorname{COAL}(15)=.02$

COAL $(16)=.01$

$\operatorname{COAL}(17)=.66$

COAL $(18)=1.69$

$\operatorname{COAL}(19)=.07$

$\operatorname{COAL}(20)=.65$

DO $10 \quad I=21.38$

$\operatorname{COAL}(I)=0$.

10 CONTINUE

COAL $(39)=1870$.

COAL $(40)=64100$

$\operatorname{COAL}(41)=2.3 E 12$

DO $20 \quad I=42,50$

$\operatorname{COAL}(I) \Rightarrow 0$.

20 CONT INUE

CALL SRC I I (Q, COAL, MRES, SLAG, SUL, SRC)

STOP

END 
SUBROUT INE SRC I I (0, COAL, MRES, SLAG, SUL, SRC )

DIMENSION COAL (50), MRES (50), SLAG (50), SUL $(50), 5 R C(50)$

REAL MRES, MRESC (50), SLAGC (50), SULC (50), SRCC (50)

C - COEFFICIENTS USED TO DETERMINE ELEMENTAL SPLIT BETWEEN

C : OUTPUT WASTE AND PRODUCT STREAMS READ IN

READ (1, 1000) (MRESC (1), SLAGC ( 1 ), SULC ( 1 ), SRCC ( 1$), 1=1,50$ )

1000 FORM $\mathrm{T}$ (F9.5.3F10.5)

C - CALCLLATION OF INPUT RA-226,RA-22E \& PB-2IO IF NOT GIVEN IF $(C O, L(21), E Q$. 0. ICOAL $(21)=3.38 E-7 \cdot \operatorname{COAL}(19)$

IF (COAL (22) .EQ. 0. ICOAL $(22)=4.01 E-10 * \operatorname{COAL}(20)$

IF (COAL (23) .EQ. O.) COAL (23) =4.37E-9*COAL ( I9)

C - CalCULATION OF TRACE ELEMENT SPLIT BETHEEN OUTPUT STREAMS

DO $10 \quad[=3,24$

MRES $([)=\operatorname{MRESC}(1) * \operatorname{COAL}(1)$

$\operatorname{SLAG}(1)=\operatorname{SLAGC}(1)+\operatorname{COAL}(1)$

SUL $(I)=\operatorname{SULC}(I) * \operatorname{COAL}(I)$

SRC ( ! ) $=\operatorname{SRCC}(1) * \operatorname{COAL}(1)$

10 CONT INUE

C NON-APPLICAELE ELEMENTS SET TO ZERO

DO $20 \mathrm{I}=26,50$

$\operatorname{MRES}(1)=0$.

$\operatorname{SLAG}(1)=0$.

$\operatorname{SUL}(I)=0$.

SRC (I) $=0$

20 CONT INUE

C - calculation of total quant ITy of Each outPut stream MRES $(25)=.2 * 0$

$S L A G(25)=.083 * Q$

$\operatorname{SRC}(25)=.3 * 0$

SUL $(25)=$ COAL $(2)-.007 * S R C(25)$

C - CALCULATION OF ASH CONTENT OF EACH OUTPUT STREAM SRC (I) $=.0015 \cdot \operatorname{SRC}(25)$

MRES $(1)=.75 *(\operatorname{COAL}(1)-\operatorname{SRC}(1))$

SLAG $(1)=.25 *(\operatorname{COAL}(1)-\mathrm{SRC}(1))$

SUL $(1)=0$.

C - CALCULATION OF SULFUR CONTENT OF EACH OUTPUT STREAM MRES $(2) \approx .02 * S U L(25)$

SLAG $(2)=.01 * 5 U L(25)$

SUL $(2)=.95 *$ SUL (25)

$S R C(2)=.007 \cdot S R C$ (25)

C - CALCULATION OF INPUT PYRITIC SULFUR

PSUL =COAL (39) /COAL (2)

C - CALCULATION OF PYRITIC SULFUR CONTENT OF EACH OUTPUT STREAM MRES (39) =PSUL * MRES ( 2$)$

$S L A G(39)=P S U L \cdot S L A G(2)$

SUL $(39)=P S U L$ SUL $(2)$

SRC (39) =PSUL = SRC ( 2$)$

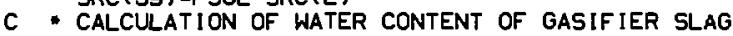

SLAG $(34)=.4 * S L A G(25)$

C CALCULATION OF CARBON CONTENT OF EACH OUTPUT STREaM $\operatorname{MRES}(40)=.28+\operatorname{MRES}(25)$

$S L A G(40) \times .001+S L A G(25)$

$\operatorname{SRC}(40)=.87 * \operatorname{SRC}(25)$

PRINT OUT OF DATA

WRITE(2,2000)0, COAL (1), MRES (1), SLAG (1), SUL (1), SRC (1),

-COAL (2), MRES (2), SLAG (2), SUL (2), SRC (2).

-COAL (3), MRES (3), SLAG (3), SUL (3), SRC (3):

-COAL (4), MRES (4), SLAG (4), SUL (4), SRC (4)

2000 FORMAT ( IH1, 5X, * INPUT COAL: "2X,EI2.5/IX, "ELEMENT*,TIG,*INPUT COAL*, 


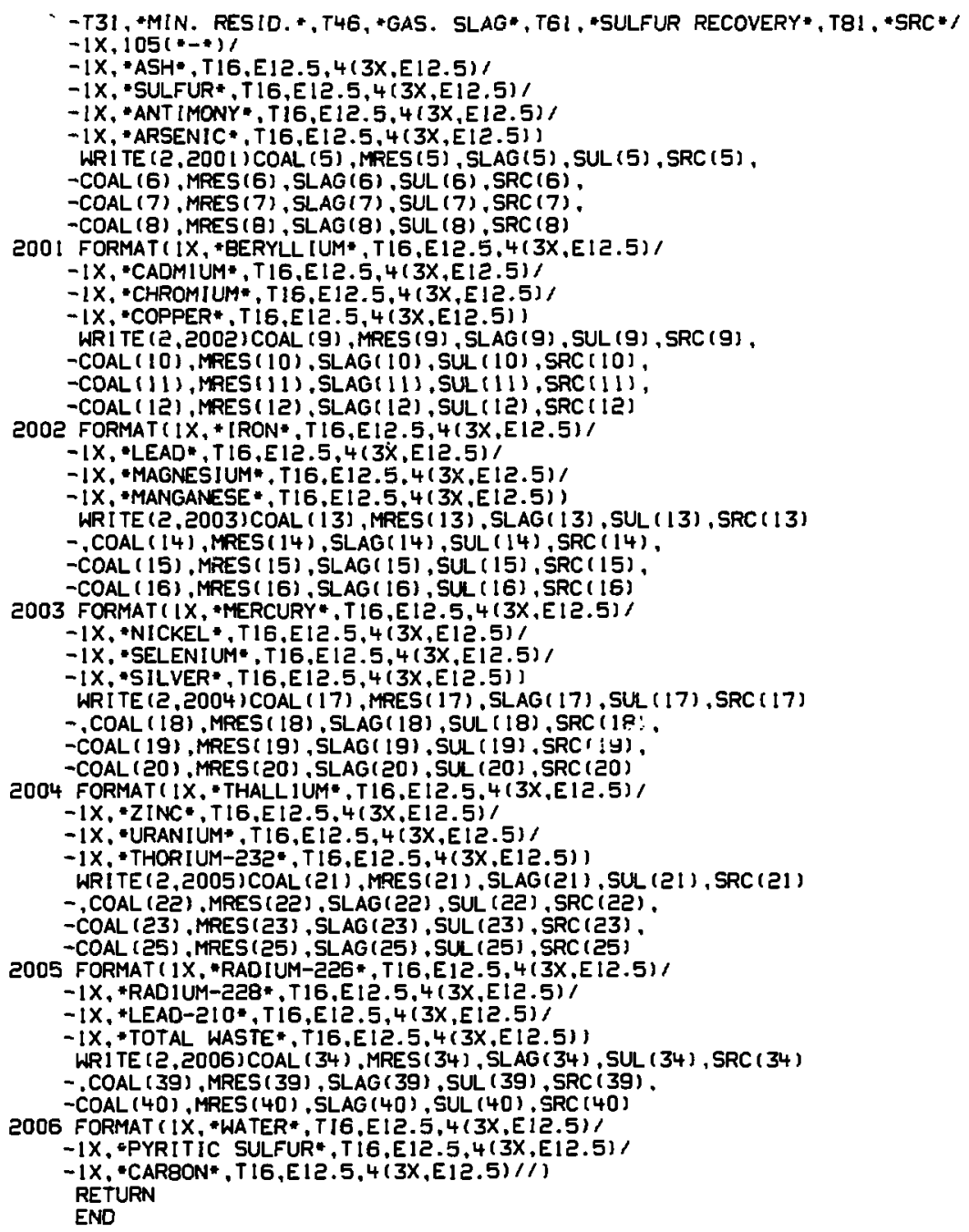




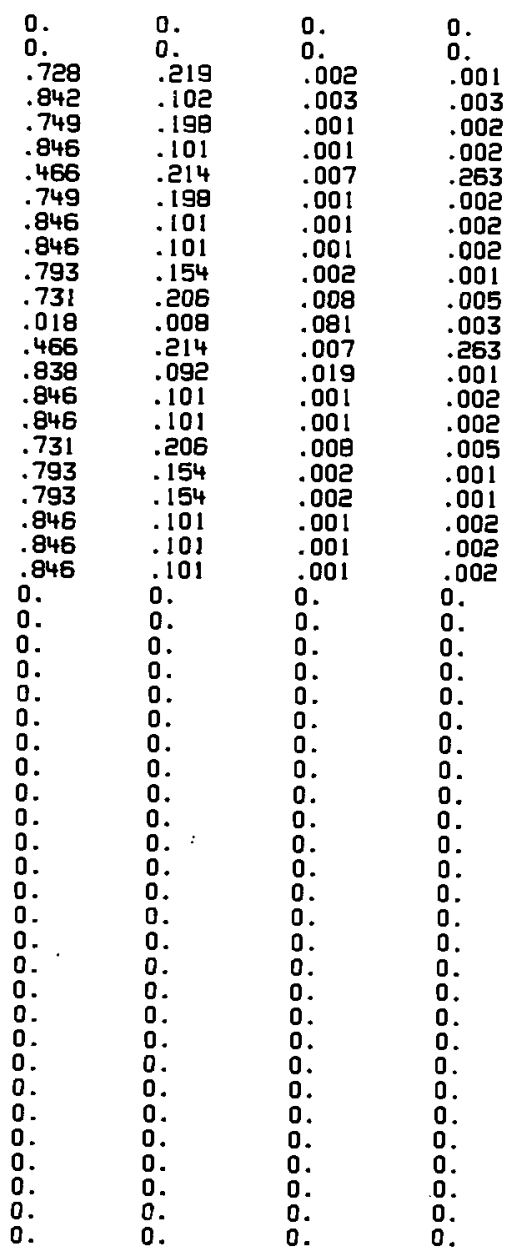


INPUT COAL: $10000 E+06$

\begin{tabular}{|c|c|c|c|c|c|}
\hline LEMENT & INPUT COAL & IN. RE & AS. SLAG & SULFUR RE & SRC \\
\hline $\begin{array}{l}\text { ASH } \\
\text { SULFUR } \\
\text { ANTIMONY } \\
\text { ARSENIC } \\
\text { BERYLLIUM } \\
\text { CADMIUM } \\
\text { CHROMIUM } \\
\text { COPPER } \\
\text { IRON } \\
\text { LEAD } \\
\text { MAGNESIUM } \\
\text { MANGANESE } \\
\text { MERCURY } \\
\text { NICKEL } \\
\text { SELENIUM } \\
\text { SILVER } \\
\text { THALLIUM } \\
\text { ZINC } \\
\text { URANIUM } \\
\text { THORIUM-232 } \\
\text { RADIUM-Z26 } \\
\text { RADIUM-Z28 } \\
\text { LEAD-2IO } \\
\text { TOTAL WASTE } \\
\text { WATER } \\
\text { PYRITIC SULFUR } \\
\text { CARBON }\end{array}$ & $\begin{array}{c}18700 E+05 \\
.30000 E+04 \\
.70000 E-01 \\
.27000 E+01 \\
.50000 E+00 \\
.12500 E+00 \\
.30000 E+01 \\
.11800 E+01 \\
.27000 E+04 \\
.11400 E+01 \\
.11800 E+03 \\
.74000 E+01 \\
.17000 E-01 \\
.20000 E+01 \\
.20000 E-01 \\
.10000 E-01 \\
.66000 E+00 \\
.16900 E+01 \\
.70000 E-01 \\
.66000 E+00 \\
.23650 E-07 \\
.26466 E-09 \\
.30590 E-09 \\
0 . \\
0 . \\
.18700 E+04 \\
.64100 E+05\end{array}$ & $\begin{array}{l}.13991 E+05 \\
.55800 E+02 \\
.50960 E-01 \\
.22734 E+01 \\
.37450 E+00 \\
.10575 E+00 \\
.13980 E+01 \\
.88382 E+00 \\
.22842 E+04 \\
.96444 E+00 \\
.93574 E+02 \\
.54094 E+01 \\
.30600 E-03 \\
.93200 E+00 \\
.16760 E-01 \\
.84600 E-02 \\
.55836 E+00 \\
.12354 E+01 \\
.55510 E-01 \\
.52338 E+00 \\
.20016 E-07 \\
.22390 E-09 \\
.25879 E-09 \\
.20000 E+05 \\
0 . \\
.34782 E+02 \\
.56000 E+04\end{array}$ & $\begin{array}{l}.46638 E+04 \\
.27900 E+02 \\
.15330 E-01 \\
.27540 E+00 \\
.99000 E-01 \\
.12625 E-01 \\
.64200 E+00 \\
.23364 E+00 \\
.27270 E+03 \\
.11514 E+00 \\
.18172 E+02 \\
.15244 E+01 \\
.13600 E-03 \\
.42800 E+00 \\
.18400 E-02 \\
.10100 E-02 \\
.66660 E-01 \\
.34814 E+00 \\
.10780 E-01 \\
.10164 E+00 \\
.23897 E-08 \\
.26731 E-10 \\
.30896 E-10 \\
.83000 E+04 \\
.33200 E+04 \\
.17391 E+02 \\
.83000 E+01\end{array}$ & $\begin{array}{l}0 . \\
.26505 E+04 \\
.14000 E-03 \\
.81000 E-02 \\
.50000 E-03 \\
.12500 E-03 \\
.21000 E-01 \\
.11800 E-02 \\
.27000 E+01 \\
.11400 E-02 \\
.23600 E+00 \\
.59200 E-01 \\
.13770 E-02 \\
.14000 E-01 \\
.38000 E-03 \\
.10000 E-04 \\
.56000 E-03 \\
.13520 E-01 \\
.14000 E-03 \\
.13200 E-02 \\
.23660 E-10 \\
.26466 E-12 \\
.30590 E-12 \\
.27900 E+04 \\
0 . \\
.16521 E+04 \\
0 .\end{array}$ & $\begin{array}{l}.45000 E+02 \\
.21000 E+03 \\
.70000 E-04 \\
.81000 E-02 \\
.10000 E-02 \\
.25000 E-03 \\
.78900 E+00 \\
.23600 E-02 \\
.54000 E+01 \\
.22800 E=02 \\
.11800 E+00 \\
.37000 E-01 \\
.51000 E-04 \\
.52600 E+00 \\
.20000 E-04 \\
.20000 E-04 \\
.13200 E-02 \\
.84500 E-02 \\
.70000 E-04 \\
.66000 E-03 \\
.473200 E-10 \\
.52932 E-12 \\
.61180 E-12 \\
.30000 E+05 \\
0 . \\
.13090 E+03 \\
.26100 E+05\end{array}$ \\
\hline
\end{tabular}




\section{SOLID WASTE MODULE FOR OIL SHALE RETORTING}

\subsection{Introduction}

As a possible substitute for petroleum, the reserves of oil shale have attracted widespread attention. Commercial interest in the extraction and processing of oil shale has existed for several decades. A viable oil shale industry has been "about to start" several times this century but each time economic, technical, political, or legal roadblocks have postponed actual development. Recently the impetus to develop domestic energy sources has prompted new interest in oil shale activities. This has also led to increased concern about the environmental impacts which might be associated with large-scale extraction and processing operations. of particular concern are the possible impacts of solid waste disposal. About $80 \%$ of the mined shale remains after retorting, giving rise to huge quantities of waste. Further, the spent shale occupies a much greater volume than the raw material.

\subsection{0il Extraction from Oil Shale}

The oil in oil shale is contained in kerogen, a solid, powdery, largely insoluble organic substance. The ofl is obtained by heating which breaks the chemical network holding the heavy kerogen molecules together and "cracks" the Individual large molecules into smaller molecules. This releases a liquid hydrocarbon mixture, some combustible gases, and a coke-like residue.

The conventional way of recovering the oil is to mine the shale and put it through the heating process aboveground. A more recent method is to break up the shale while it is still in the ground and heat it in place (in situ). 
Conventional Recovery. Conventional recovery consists of four basic steps: mining the shale, crushing it to the proper size for the retort vessel, retorting the shale to release the oil, and refining the oil to bring it up to a high-quality product. The shale is mined either underground or on the surface by conventional methods. It is then crushed and reduced to the size required for the particular heating method to be used.

The crushed shale is fed into a closed retorting vessel and heated to very high temperatures - between $800^{\circ}$ and $1000^{\circ} \mathrm{F}$ - to decompose the kerogen. The various retorting processes apply heat to the shale in different ways.

The oily vapor produced as the kerogen decomposes during retorting is condensed to form the raw shale ofl. This oil has a high nitrogen content as well as appreciable quantities of sulfur and oxygen.

At the refinery, raw shale oil is upgraded to remove the nitrogen, sulfur, and oxygen. This is done by reacting the ofl with hydrogen so that it becomes a synthetic crude oil that is essentially the same as high grade conventional crude oil.

In Situ Recovery. In "true" in situ processing, the in place shale is fractured using explosives to create void spaces in the shale. The shale is ignited and a combustible gas pumped in. The hot combustion gases circulate along the pathways in the fractured shale heating it to retorting temperature. The vapors produced condense to a liquid in a sump at the base of the shale area and is pumped to the surface.

In a "modifled" version of the in situ recovery, about $30 \%$ of the lower portion of the shale bed is first mined by conventional methods. This portion is retorted aboveground. 


\subsection{Processes Used in the Module}

At present, there are no full-scale oil shale operations. The module, therefore, will compute the solid waste produced from the two conventional processes closest to commercialization - TOSCO II and Paraho (direct mode). In both cases, full-scale plants have been designed and it is on these plans that the solid waste module is based.

The basic distinction between the processes is the method of heat transfer. In the Paraho process (Figure 6.1), the heat for retorting is supplied by combustion of residual carbonaceous material in denuded shale in the lower portion of the retorting vessel. The hot combustion gases flow upwards through the shale liberating shale oil vapors at a temperature of approximately $900^{\circ} \mathrm{F}$ from the fresh shale entering the upper section of the vessel. In the proposed commercial Paraho process, the raw shale oil is condensed and stor? without any further on-site processing. In the TOSCO II process (Figure 6.2), preheated shale is fed to a horizontal rotating retort (pyrolysis drum) where a charge of hot ceramic balls contacts the raw shale, raising its temperature to $9000 \mathrm{~F}$. The organic matter in the shale is converted to shale oil vapor which is withdrawn from the retorting vessel. In the proposed commercial Tosco II process the raw shale oil is upgraded onsite.

A true in situ process produces no waste requiring disposal. The modified in situ plant has 20 to $30 \%$ of the shale mined by conventional methods. This can be retorted using conventional methods. Therefore, for the modified in situ plant the model can be run using an input quantity of raw shale which reflects the initial 20 to $30 \%$. 


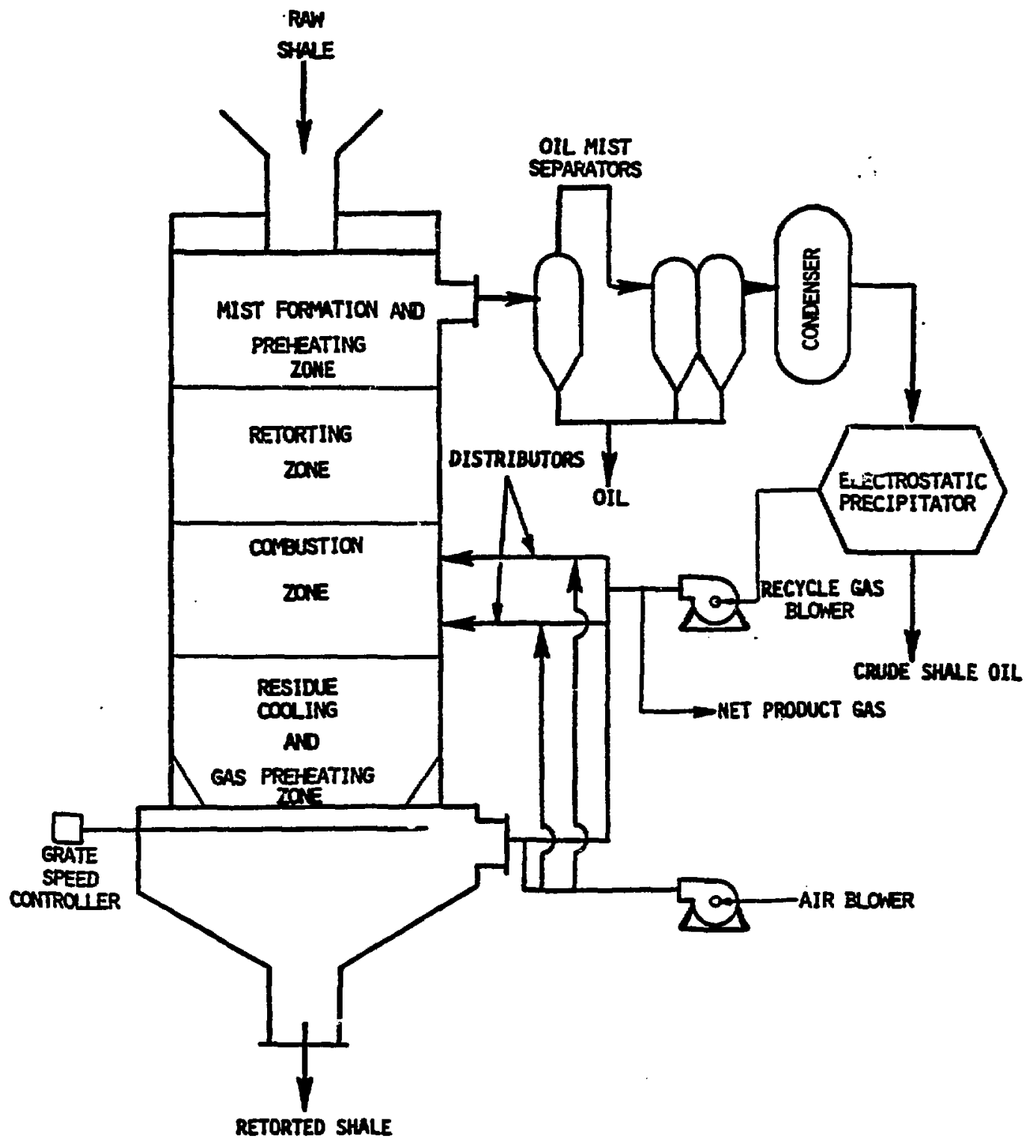

Figure 6.1 Paraho process. (From Reference 2.) 


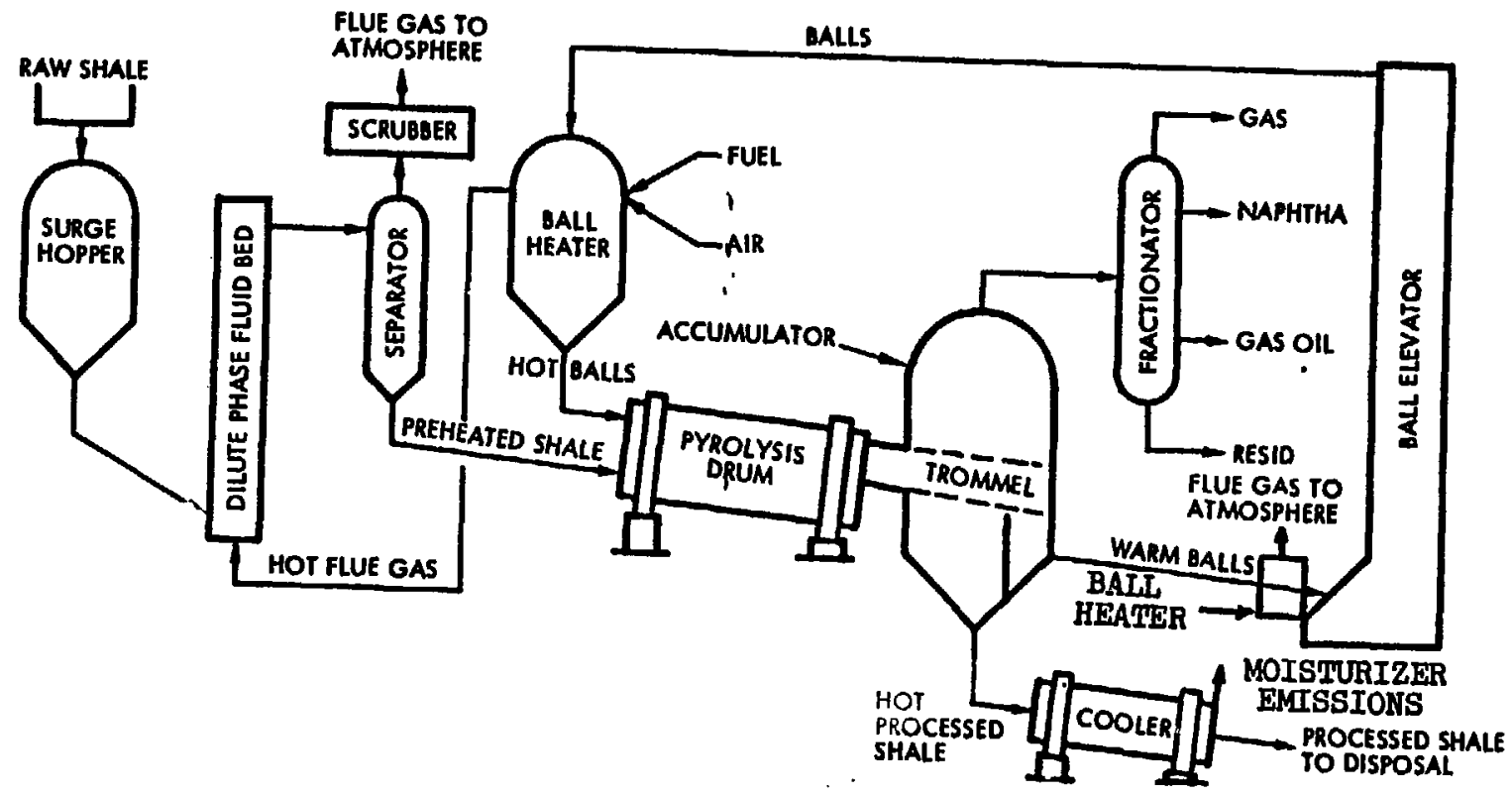

Figure 6.2 Tosco II process. (From Reference 2.) 
6.4 Solid Waste Produced by O11 Shale Recovery

The major quantities of solid waste are from the crushing and retorting operations.

In the TOSCO II process there is no minimum size for the shale particles entering the retort and so the only waste comes from the collection of fugitive particulate matter. For the Paraho process, the minimum particle size is $3 / 8-i n .1$ The $<3 / 8-i n$. fines can either be disposed of as waste or briquetted and sent to the retorts.

In both cases the composition of the waste is, of course, essentially the same as that of the raw shale.

By far the largest quantity of waste comes from the spent shale. In the module this also includes particulate matter which is collected during the retorting process.

The character of the waste depends on the retorting process used. Spent shale from the TOSCO II process contains about $5 \%$ residual carbonaceous materlal, whereas in the Paraho process the spent shale is partlally "burned" after pyrolysis of ofl shale kerogen and contains only $2 \%$ organic carbon. The composition of Paraho spent shale is similar to Portland cement. It also has some cement-like properties which help to create stable disposal piles. The TOSCO II waste consists of very fine crystalline particles. There are no cement-like properties, and this could lead to problems with pile stability and leaching.

Table 6.1 lists the other wastes produced by ofl shale processing. Only the quantity of recovered arsenic will be given in the module. The blo-oxidation sludge is as dependent on the water composition as on the process and can vary greatly, making tt impossible to model in this type of 
Table 6.1

Solid Waste Other than Spent Shale

\begin{tabular}{llll}
\hline Waste Description & Source & Process & Disposition \\
\hline Bio-oxidation sludge & $\begin{array}{l}\text { Frocess condensate } \\
\text { Domestic waste }\end{array}$ & $\begin{array}{l}\text { Paraho } \\
\text { TOSCO II }\end{array}$ & $\begin{array}{l}\text { Spent shale } \\
\text { Spent shale }\end{array}$ \\
Sulfur & Sulfur recovery & $\begin{array}{l}\text { Paraho } \\
\text { Tosco II }\end{array}$ & $\begin{array}{l}\text { Sell as by-product } \\
\text { Sell by-product }\end{array}$ \\
API separator sludge & Oil/water separator & $\begin{array}{l}\text { Paraho } \\
\text { TOSCO II }\end{array}$ & $\begin{array}{l}\text { Return to retort } \\
\text { Return to retort }\end{array}$ \\
Shale oil coke & Refinery & ToSCO II & Sell as by-product \\
Spent catalysts & Refinery & TOSCO II & $\begin{array}{l}\text { Ship to manufacturer } \\
\text { for recovery }\end{array}$ \\
Arsenic & Refinery & TOSCO II & Ship to hazardous \\
& & & waste disposal \\
\end{tabular}

module. The oil coke and sulfur are to be sold and therefore do not constitute a waste product. The present plans also assume that the catalysts will be shipped to the manufacturer for recovery. Even if they were to be disposed of on site; the intermittent nature of their disposal makes it Impossible to model in this module.

\subsection{OIl Shale Module Description}

The module assumes constant removal rates for each of the input trace elements for each of the streams quantified. That is, a constant fraction of the total input elements will be retained in the spent shale, etc. (these constants will necessarily be different for each element and for each stream).

The input to the module is the quantity of raw oil shale and its composition in terms of sulfur, carbon, and trace elements and an integer value ( 1 to 4 ) to indicate which retorting process is to be employed (Paraho, Tosco II, or modified in situ using elther Paraho or TOSCO II). 
Figure 6.3 gives an overall view of the module. For both processes the sequence is the same but the coefficients vary. The module first computes the amount of shale which is lost during crushing operations and appears as solid waste. The I awainder of the shale goes to retorting. Here the total quantities of solid waste and product oil are calculated. The amounts of the trace elements in the spent shale and oil are computed. There are also gas and condensate water streams in the retorting process, but since the module is concerned with solld waste these are not included. To simply give the approximate quantity of the elements in the initial gas stream would not be very meaningful, since the gas undergoes a number of cleaning steps, and a fraction is recycled to provide heat for the retorting process. Therefore, the final composition of the gas vented to the atmosphere would be very different. For the TOSCO II process the amount of recovered arsenic is also given.

The module is called by the main program with the following arguments:

Total input quantity of oil shale

Input vector of oil shale characteristics

Output vector of raw shale waste composition

Output vector of spent shale composition

Output vector of crude oill composition

Output vector of recovered arsenic

Type of process to be employed. Integer number: 1 - Paraho;

2 - Tosco II; 3 - modified in situ using Paraho; and 4 - modified

in situ using TOSCO II.

Grade of ofl shale (gal/ton) 


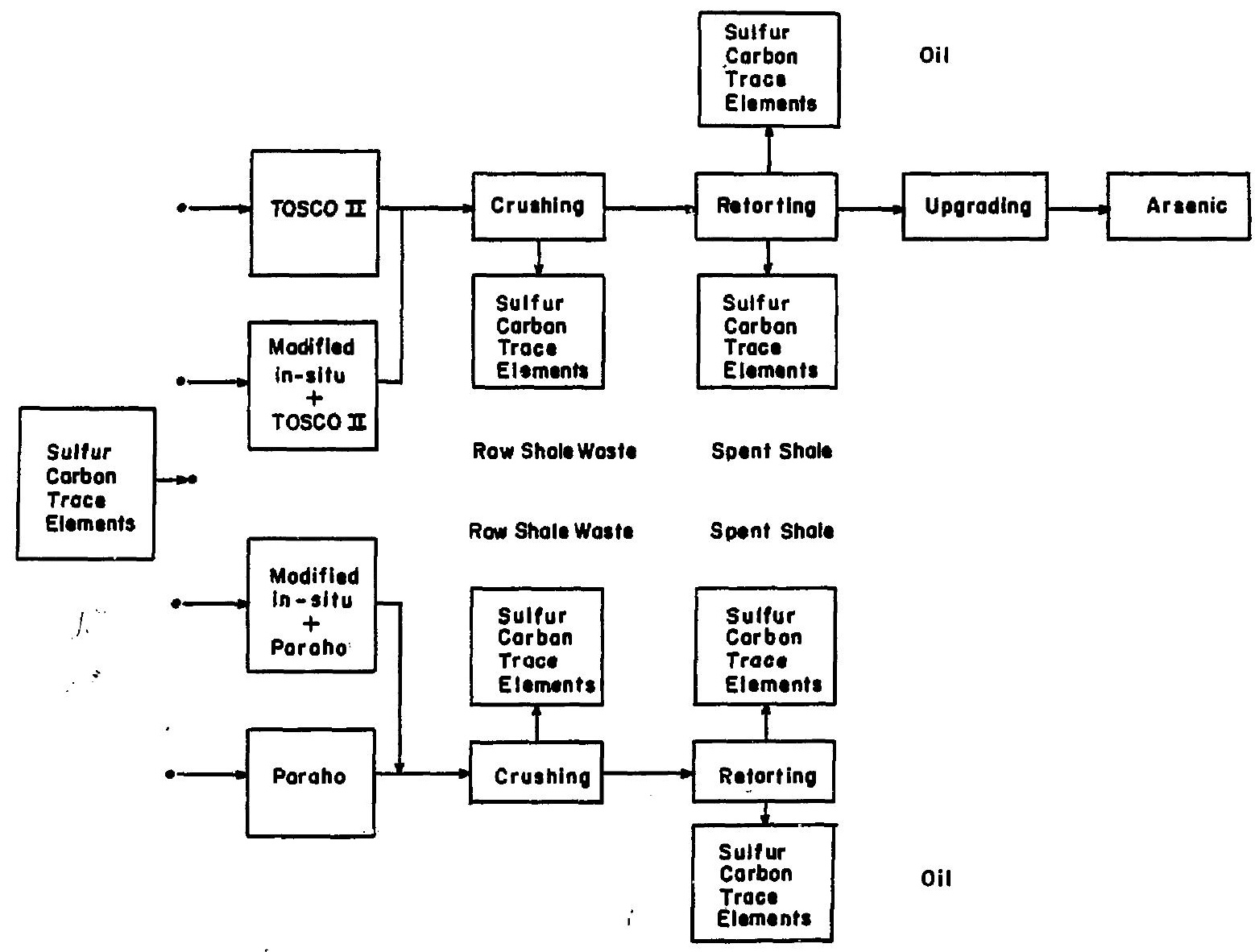

Figure 6.3 Overall oil shale module design. 
The input and output vectors each contains 50 elements (Table 6.2). Since these vectors are constructed to be conformable to any of the solid waste modules which have been produced, there are presently some empty elements ( 48 to 50, not shown) and some elements which are not applicable to this module and as such are disregarded (set to 0 ) in the output vectors and omitted in the output printout.

Tables 6.3 and 6.4 give the equations for the total quantities of waste and product oil and their major components, for the TosCO II and Paraho processes respectively. The coefficient for the total quantity of spent shale is used to calculate the dry weight. The output vector elements give the disposal weight, i.e., dry weight plus water.

Table 6.5 gives the coefficients which determine the amount of each trace element in the spent shale and oil. In addition, for trace elements in the raw shale waste strean the coefficients are the same as for the total waste, i.e., 0.007 for TOSCO II and 0.05 for Paraho. The reduced amounts are then used as input to the retorting process.

Because there are few good data available on the fate of the trace elements during retorting, many of the figures are very rough estimates. They will need to be revised when better data become available.

It should also be noted that in a number of cases less than a $100 \%$ of an element is accounted for. Thts is because the remainder is found in the gas and water condensate streams which are not considered in the module.

The appendices give more information on the source of the coefficients and details of the computer code. 


\begin{tabular}{|c|c|c|c|}
\hline & & $\begin{array}{l}\text { ble } 6.2 \\
\text { ements }\end{array}$ & \\
\hline Number & Type & Number & Type \\
\hline 1 & Ash & 24 & Hydrocarbons \\
\hline 2 & Sulfur (S) & 25 & Total solid waste \\
\hline 3 & Antimony (Sb) & 26 & Unreacted 11mestone \\
\hline 4 & Arsenic (As) & 27 & Calcium sulfite \\
\hline 5 & Beryllium ( $\mathrm{Be})$ & 28 & Calcium sulfate \\
\hline 6 & Cadmiun (Cd) & 29 & Soda ash \\
\hline 7 & Chromium (Cr) & 30 & Magnesium sulfite \\
\hline 8 & Copper $\left(\mathrm{Cu}_{11}\right)$ & 31 & Magnesium oxide \\
\hline 9 & Iron ( $\mathrm{Fe})$ & 32 & Sodium bisulfite \\
\hline 10 & Lead $(\mathrm{Pb})$ & 33 & Sodium sulfite \\
\hline 11 & Magnesium (Mg) & 34 & Water \\
\hline 12 & Manganese (Mn) & 35 & Sulfur dioxide \\
\hline 13 & Mercury ( $\mathrm{Hg})$ & 36 & Nitrous oxides \\
\hline 14 & Nickel (Ni) & 37 & Carbon monoxide \\
\hline 15 & Selenium (Se) & 38 & Methane \\
\hline 16 & Silver (Ag) & 39 & Pyritic sulfur \\
\hline 17 & Tha1lium (T1) & 40 & Carbon \\
\hline 18 & Zinc $(\mathrm{Zn})$ & 41 & Btu \\
\hline 19 & Uranium-238（U) & 42 & Carbon dioxide \\
\hline 20 & Thorium-232 (Th) & 43 & Sodium bicarbonate \\
\hline 21 & Radium-226 (Ra) & 44 & Sodium carbonate \\
\hline 22 & Radium-228 ( $R a)$ & 45 & Sodium sulfate \\
\hline \multirow[t]{2}{*}{23} & Lead-210 ( $\mathrm{Pb})$ & 46 & Calcium carbonate \\
\hline & & 47 & Calcium oxide \\
\hline
\end{tabular}


Table 6.3

Coefficients for Total Output and Major Components for TOSCO II

\begin{tabular}{lclll}
\hline Components & Raw Shale Waste & Spent Shale & \multicolumn{1}{c}{ OIl } & Arsenic Waste \\
\hline Total quantity (dry) & $0.007 \mathrm{I}_{\mathrm{Os}}$ & $0.81 \mathrm{R}_{\mathrm{OS}}$ & $0.004 \mathrm{R}_{\mathrm{os}} \times 0 G$ & $0.0075 \mathrm{R}_{\mathrm{a}} \times 5.0$ \\
Sulfur & $0.007 \mathrm{I}_{\mathrm{s}}$ & $0.79 \mathrm{R}_{\mathrm{s}}$ & $0.08 \mathrm{R}_{\mathrm{s}}$ & \\
Carbon & $0.007 \mathrm{I}_{\mathrm{C}}$ & $0.2 \mathrm{R}_{\mathrm{c}}$ & $0.7 \mathrm{R}_{\mathrm{c}}$ & \\
Water & & $0.14 \mathrm{O}_{\mathrm{ss}}$ & & \\
Arsenic & & & & $0.0075 \mathrm{R}_{\mathrm{a}}$ \\
\hline
\end{tabular}

$I_{\mathbf{x}}=$ Total input amount of substance $x$.

$O_{x}=$ Total output amount of substance $x$.

$R_{x}=$ Total amount of substance $x$ into the retort $\left(I_{x}-0.007 I_{x}\right)$.

os = O11 shale.

s = Sulfur.

c = Carbon.

ss = Spent shale.

OG = Grade of oil shale (gal/ton raw oil shale).

$a$ = Arsenic.

Table 6.4

Coefficients for Total Output and Major Components for Paraho

\begin{tabular}{lccl}
\hline Components & Raw Shale Waste & Spent Shale & \multicolumn{1}{c}{ Ofl } \\
\hline Total quantity (dry) & $0.05 \mathrm{I}_{\mathrm{OS}}$ & $0.8 \mathrm{R}_{\mathrm{Os}}$ & $0.004 \mathrm{R}_{\mathrm{Os}} \times 0.920 \mathrm{G}$ \\
Sulfur & $0.05 \mathrm{I}_{\mathrm{s}}$ & $0.79 \mathrm{R}_{\mathrm{S}}$ & $0.08 \mathrm{R}_{\mathrm{S}}$ \\
Carbon & $0.05 \mathrm{I}_{\mathrm{c}}$ & $0.08 \mathrm{R}_{\mathrm{c}}$ & $0.7 \mathrm{R}_{\mathrm{c}}$ \\
Water & & $0.05 \mathrm{O}_{\mathrm{SS}}$ & \\
\hline
\end{tabular}

$I_{x}=$ Total input amount of substance $x$.

$Q_{x}=$ Total output amount of substance.

$R_{x}=$ Total amount of substance $x$ into retort $\left(I_{x}-0.05 I_{x}\right)$.

os = 011 shale.

$s=$ Sulfur.

$c=$ Carbon.

ss = Spent Shale.

$O G=$ Grade of oil shale (gal/ton raw ofl shale). 
Table 6.5

Fractional Split of Trace Elements between Spent Shale and 011

\begin{tabular}{|c|c|c|}
\hline Element & Spent Shale & 011 \\
\hline Antimony & 99.9 & 0.1 \\
\hline Arsenic & 85.0 & 5.0 \\
\hline Beryllium & 100.0 & 0.0 \\
\hline Cadmium & 100.0 & 0.0 \\
\hline Chromium & 99.8 & 0.2 \\
\hline Copper & 99.9 & 0.1 \\
\hline Iron & 99.9 & 0.1 \\
\hline Lead & 99.9 & 0.1 \\
\hline Magnesium & 99.9 & 0.1 \\
\hline Manganese & $99 . \overline{9}$ & 0.1 \\
\hline Mercury (Paraho) & 4.8 & 5.2 \\
\hline Mercury (TOSCo II) & 1.4 & 6.7 \\
\hline Nickel & 99.1 & 0.9 \\
\hline Selenium & 89.9 & 0.1 \\
\hline Silver & 99.9 & 0.1 \\
\hline Thallium & 99.9 & 0.1 \\
\hline Zinc & 99.6 & 0.4 \\
\hline Uranium & 99.9 & 0.1 \\
\hline Thorium & 99.9 & 0.1 \\
\hline Radium & 99.9 & 0.1 \\
\hline
\end{tabular}




\section{REFERENCES}

1. U.S. Department of Energy, Environmental Control Costs for 0il Shale Processes, DOE/EV-0055, Washington, DC, 1979.

2. TRW, A Preliminary Assessment of the Environmental Impacts from 011 Shale Developments, EPA-600/7-77-069, prepared for U.S. Environmental Protection Agency, Washington, DC, 1979.

3. T.A. Henderson (ed.), Synthet1c Fuels Data Handbook, Cameron Englneers, Inc., Denver, Co, 1975.

4. Bureau of Standards, Thermal Properties of Petroleum Products, Miscellaneous Publication No. 97, U.S. Department of Comerce, Hashington, DC, 1929.

5. A.D. Schendrikar and G.B. Faudel, Distribution of trace metals during oil shale retorting, Environ. Sci. and Technol., 12, 332, 1978. 


\section{APPENDIX 6A}

CALCULATION OF MAJOR COMPONENTS OF OUTPUT STREAMS

\section{A.1 Raw Shale and Spent Shale Waste}

The figures are based on the actual quantities of waste that are expected from a commercial size plant as given in the present plant designs 1,2 .

The waste from crushing is greater for the Paraho process because some fines are included.

For both processes the spent shale from retorting includes particulate matter collected from the retorting process and from the wetting of the spent shale prior to disposal.

\section{A. 2 Water}

In both cases, the spent shale is moistened prior to disposal. Since the waste from the two processes has differing characteristics, different amounts of water are required. Again the quantities are based on plant designs 1 .

\section{A.3 Crude 0il Production}

In order to be compatible with the rest of the output elements, the quantity of oil product is given in tons.

The grade of oll shale in terms of gallons of oil per ton of shale is given as an input. It is determined with a Fisher Assay, which uses a bench retorting system to determine the quantity of oil in a sample of shale. The TOSCO II process should recover $100 \%$ of the Fisher Assay; however, in the Paraho process the expected yield is only 92\%. The oil production is converted from gallons to tons using a density of $7.71 \mathrm{~b} / \mathrm{gal}^{3}, 4$. 
6A. 4 Sulfur

The distribution of sulfur comes from a Fisher Assay ${ }^{3}$. The distribution may be different in commercial plants. Using this distribution does give reasonable agreement with some figures given in References 1 and 2.

\section{A. 5 Carbon}

The module only considers the fate of the organic carbon. The only complete data available are for the total kerogen. It is therefore assumed that the carbon has the same distribution. The split again comes from a Fisher Assay, 3 which gives a large organic residue remaining in the shale after pyrolysis. In commercial operations, depending on the process, this residue may be partially burned after pyrolysis, e.g., the Paraho process. In the TOSCO II process the organic residue is not burned; it was therefore decided to use the split given by the Fisher Assay. This does give reasonable results for the amount of carbon left in the spent shale for the TOSCO II process 2 . In the Paraho process the residue is partially burned and the spent shale contains on 1 y $2 \%$ carbon as opposed to $5 \%$ for the TOSCO II process ${ }^{2}$. It was assumed that the same amount of carbon appeared in the oil as for Tosco II, but the amount in the spent shale was reduced. The remainder is assumed to be in the gas as combustion products.

6A.6 Recovered Arsenic

In the TOSCO II process arsenic is recovered during upgrading procedures. The amount is from the plant design and it is assumed that arsenic constitutes $20 \%$ of the total waste ${ }^{1}$. 
Very few data are avallable on the trace metals in oil shale and their fate during retorting. In many cases the coefficients are 1ittle more than conjectures.

The only reported results on the mass balance of elements around a retort are for the following elements ${ }^{5}$ :

$\begin{array}{lll}\text { As } & \mathrm{Cu} & \mathrm{Se} \\ \mathrm{Be} & \mathrm{Pb} & \mathrm{Zn} \\ \mathrm{Cd} & \mathrm{Mn} & \\ \mathrm{Cr} & \mathrm{NI} & \end{array}$

These results were based on a Fisher Assay and concentrations were measured only in the oil, spent shale, and condensate water. No measurements were made of the gaseous phase. In most cases this does not appear to matter; except for As and Se, mass balances close to unity were achieved and it would appear that virtually all elements remain with the spent shale. This is also the conclusion given in Reference 1 . From Reference 1 it is assumed that $10 \%$ of the As and Se appear in the gas. This is in agreement with the unrecovered portion shown in Reference 5. The mass balances given in Reference 5 were therefore recalculated assuming that $10 \%$ of these elements escaped with the gas.

The route of $\mathrm{Hg}$ in a commercial plant is highly speculative. Although it is assumed that virtually all of the $\mathrm{Hg}$ initially appears in the gas, it may later condense and appear in the spent shale, oil, recovered sulfur, and spent catalysts $^{1}$. The amount of $\mathrm{Hg}$ in the spent shale and gas could vary by $90 \% .1$ 
At present, in the module $\mathrm{It}$ is assumed that the majority of the $\mathrm{Hg}$ is in the gas. However, if evidence becomes available that more $\mathrm{Hg}$ is found elsewhere the figures will have to be revised.

There are no data for the remaining elements.

$\begin{array}{cc}\mathrm{Sb} & \mathrm{Tl} \\ \mathrm{Fe} & \mathrm{U} \\ \mathrm{Mg} & \mathrm{Th} \\ \mathrm{Ag} & \mathrm{Ra}\end{array}$

Since these elements are not very volatile, it is assumed that they remain with the spent shale. 
APPENDIX 6C

DESCRIPTION OF COMPUTER MODULE

The oil shale solid waste module consists of one subroutine and a data file containing the fraction of the input components that are removed to the solid waste. The module is set in motion by a call to SHALE:

CALI SHALE (QS, OILSH, RAWSH, SPENTS, OIL, ARSNC, OGRADE, IMETH), where

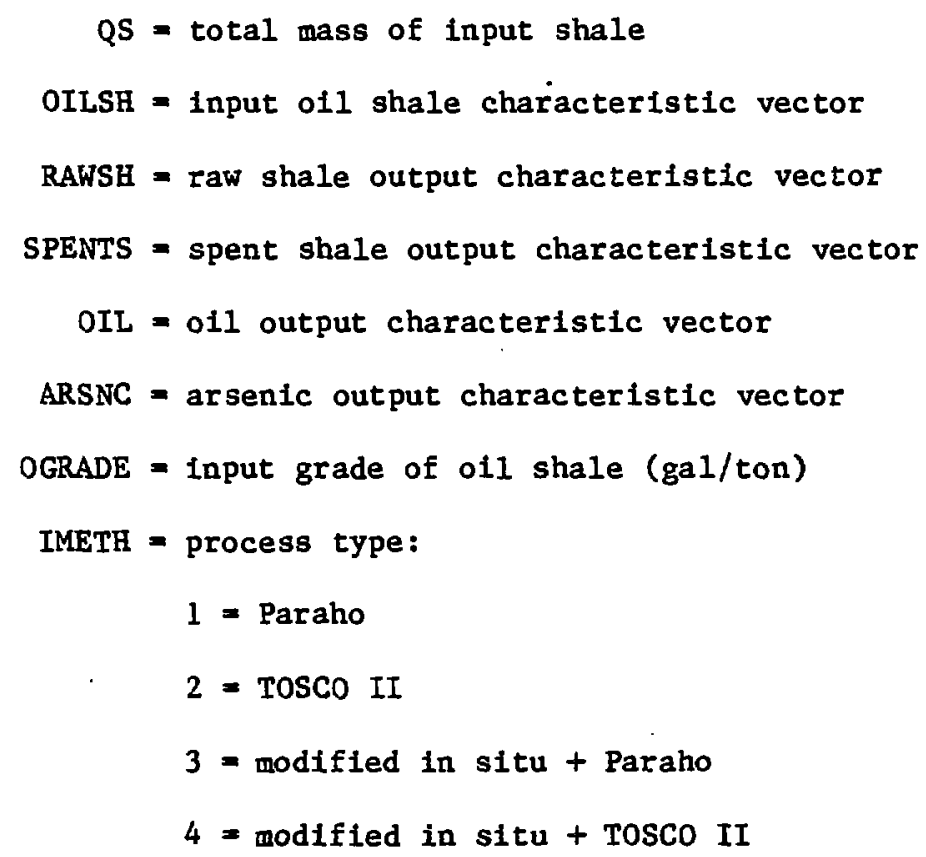

The subroutine calculates the solid waste characteristics of each waste stream and prints them out (see Appendix 6D for sample output). The data file contains the coefficients of all elements that are removed at a constant rate for both processes and can be calculated by a simple multiplication. All elements in the input vector that are empty, are not applicable to this module, are calculated differently for the two processes, or are calculated 
other than by a single multiplication (e.g., water and total solid wastes) have corresponding coefficients of zero.

All calculations (including dummy calculations for empty and nonapplicable elements) are done through DO loops in the module. The water, sulfur, carbon, arsenic, and mercury elements are calculated separately for each process.

The module prints out the input oil shale, output oil and waste vectors (applicable elements only). If this printout is not desired at some future time, the printout section can simply be removed with no effect on the solid waste calculations. All vectors are returned to the calling program intact, including the input oil shale characteristics.

The data file is presently read in as "TAPE1". 


\section{APPENDIX 6D}

COMPUTER CODE AND SAMPLE OUTPUT

This section sets out the computer code used for the oll shale module and the data file of coefficients, with a sample input and the resulting output. Table 6D.1 gives the ofl shale sharacteristics used as input. The other Input variables used were as follows:

Quant1ty of oil shale $(Q S)=100,000$ tons

Grade of oil shale (OGRADE) $=35 \mathrm{gal} / \mathrm{ton}$

Process $($ IMETH $)=2($ TOSCO II $)$

At present the main program of the code is used only to set the input variables.

\begin{tabular}{lrr}
\hline & Table 6D. \\
& Input Characteristics of 011 Shale \\
\hline Element & Input Quantity (tons) \\
\hline Sulfur & 700.00 \\
Antimony & 0.15 \\
Arsenic & 4.00 \\
Berylium & 0.10 \\
Cadmium & 0.10 \\
Chromium & 3.50 \\
Copper & 4.00 \\
Iron & 4720.00 \\
Lead & 2.50 \\
Magnesium & 1550.00 \\
Manganese & 25.00 \\
Mercury & 0.02 \\
Nickel & 2.50 \\
Selenium & 0.15 \\
Silver & 0.01 \\
Thallium & 0.01 \\
Zinc & 7.00 \\
Uranium & 0.37 \\
Thorium & 1.20 \\
Pyritic sulfur & 400.00 \\
Carbon & 10465.00 \\
\hline
\end{tabular}


PROGRAM CLL ( TAPE ! OUTPUT, TAPEE=OUTPUT )

DIMENSION OILSH(5D)

REAL RAWSH(50), SPENTS (50), O1L (50), ARSNC (50)

$0 S=100000$

OILSH $(1)=0$.

OILSH $(2)=700$.

OILSH $(3)=.15$

OILSH $(4)=4.0$

OILSH(5) $=.1$

OILSH $(6)=.1$

OILSH ( 7) $=3.5$

OILSH(B) $=4.0$

OILSH $(9)=4720$

OILSH $(10)=2.5$

OILSH $(11)=1550$

OILSH ( 12$)=25$.

OILSH $(13)=.02$

OliSH $(14)=2.5$

OILSH $(15)=.15$

OILSH $(16)=.01$

$0[\operatorname{LSH}(17)=.01$

OILSH $[18]=7.0$

0 ILSH $(19)=.37$

OILSH $(20)=1.2$

DO $10 \quad[=21,38$

OILSHCI $]=0$.

10 CONT INUE

$O$ ILSH $(39)=400$.

OILSH $(40)=10465$

$\operatorname{OILSH}(41)=0$.

DO $20 \mathrm{~J}=42,50$

$\operatorname{OILSH}(1)=0$.

20 CONTINUE

OGRADE $=29$.

IMETH=1

CALL SHALE (QS, OILSH,RAWSH, SPENTS, O IL, ARSNC, OGRADE, IMETH) STOP

END 
SUBROUT INE SHALE (QS, OILSH, RAWSH, SPENTS, OIL, ARSNC, OGRADE, IMETH) DIMENSION OILSH(50), RAWSH (50), SPENTS (50), OIL (50), ARSNC (50)

REAL RAWSH, RAWSHC (50), SPENTSC (50), OILC (50), ARSNCC (50)

C - COEFF ICENTS USED TO DETERMINE ELEMENTAL SPLIT BETWEEN

C PRODUCT AND WASTE STREAMS READ IN READ ( 1,1000$)$ (RAWSHC $(1), \operatorname{SPENTSC}(1), 01 L C(1), \operatorname{ARSNCC}(1), 1=1,50)$

1000 FORMAT (F9.5, 3F 10.5$)$

C CALCULATION OF INPUT RA-226, RA-EZB \& PB-2IO IF NOT GIVEN IF (OILSH(2) . EQ. 0. 1OILSH(21) $=3.38 E-7 * 0$ ILSH(19) IF (OILSH(2Z) .EO. 0.1OILSH (22) $=4.01 E-10 * 0$ ILSH(20) IF (OILSH+(23) .EQ. 0. 10ILSH(23) $=4.37 E-9 * 0$ [LSH(19) DO $10 \quad I=1.50$

C TOSCOII PRUCFSS .7\% CRUSHING LOSS AS SOLID WASTE

C paraho procese 5\% CRUShing loss as sol io waste IF IIMETH .EQ. 2 .OR. IMETH .EQ. 4)RAWSHC $(1)=.007$ IF (IMETH .EQ. I .OR, IMETH ,EO. 3)RAWSHC (1)=.05

C CALCULATION OF ELEMENTAL SPLIT EETHEEN OUTPUT STREAMS RAWSH ( I) =RAWSHC ( I)*OILSH ( I) SPENTS ( [ ) =SPENTSC ( [) * (OILSH ( I) -RAWSH ( [ ) OIL (I) =OILC (I) * COILSH (I)-RAWSH I I) ) ARSNC (I) =ARSNCC ( I ) * (OILSH ( I ) -RAWSH (I))

10 CONT INUE IF I IMETH .EO. I .OR. IMETH .EQ. 3)GO TO IOI

C FOLLOWING CALCULATIONS FOR TOSCOI I PROCESS

C calCulation of total quant ITY OF OUTPUT STREAMS RAWSH $(25)=.007 * 05$ SPENTS $(25)=.81 *(0 S-R A W S H(25))$ OIL $(25)=.004 *$ OGRADE *(OS-RAWSH $(25)$ ) ARSNC (25) $=5.00075 *($ OILSH (4)-RAWSH (4))

C calculation of sulfur in SPENT SHALE and oIl SPENTS $(2)=.79 * 10 I L S H(2)-R A W S H(2))$ $\operatorname{OIL}(2)=.08 *(O I L S H(2)-R A W S H(2))$

C calculation of Pyritic SULFUR IN SPENT SHaLe and OIL SPENTS (39) $=.79 *($ OILSH (39) -RAWSH ( 39$)$ )

OIL $(39)=.08 *($ OILSH (39) -RAWSH (39) )

C CALCULATION OF CAREON IN SPENT SHALE AND OIL SPENTS $(40)=.2+(0$ ILSH( 40$)$-RAWSH (40)) OIL $(40)=.7 *(O I L S H(40)-$ RAWSH $(4 D))$

C CALCULATION OF ARSENIC IN ARSENIC WASTE ARSNC ( 4 ) $=.0075 * 10$ [LSH ( 4 ) -RAWSH ( 4$)$ )

C * calculation of mercury in SPENT sHaLe and oIl SPENTS $(13)=.014 *(0$ ILSH $(13)-$ RAWSH $(13))$

OIL $(13)=.067 * 10$ ILSH ( 3 3)-RAWSH ( 13) )

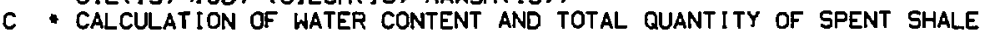
SPENTS $(34)=.14$ SPENTS (25) SPENTS ( 25 ) =SPENTS ( 25 ) +SPENTS ( 34 ) GO TO 12

c following calculations for paraho process

C * CalCULATION OF total QUANT ITY OF OUTPUT STREAMS

101 RAWSH $(25)=.05 * 05$ SPENTS $(25)=. \theta *(0 S-R A W S H(25))$ OIL $(25)=.004 * .92 *$ OGRADE*(OS-RAWSH (25))

C - CALCULATION OF SULFUR \& PYRITIC SULFUR CONTENT OF SPENT

C - shale and oil SPENTS $(2)=.79 *(0 I L S H(2)-R A W S H(2))$ SPENTS $(39)=.79 *(0$ ILSH $(39)-$ RAWSH $(39)$ ) 
OIL $(2)=.08 *(O I L S H(2)-R A W S H(2))$

OIL $(39)=.00 *$ (OILSH $(39)-\operatorname{RAWSH}(39)$ )

C - calculation of CARBON CONTENT OF SPENT SHALe and OIL SPENTS $(40)=.08 *(0 I L S H(40)-$ RAWSH( 401$)$ OIL $(40) \times .7 *$ OOILSH $(40)-$ RAWSH $(40)$ )

C calculation dF water content and total amOUNT of sPEnt shale SPENTS $(34)=.05 *$ SPENTS $(25)$ SPENTS (25) $\times$ SPENTS (25) +SPENTS ( 34 )

C * CALCULATION OF MERCURY CONTENT OF SPENT SHALE AND OIL SPENTS $(13)=.048 *$ (OILSH $(13)$-RANSH $(13))$

$\operatorname{OIL}(13)=.052 *(0 I L S H(13)-\operatorname{RAWSH}(13))$

$c$
$C$
$C$
$C$
$C$

PRINT OUT OF DATA

I2 WRITE (2,2000) OS. OILSH(1), RAWSH (1), SPENTS (1), OIL (1), ARSNC (1), -OILSH (2), RAWSH( 2 ), SPENTS ( 2$), 0 I L(2), A R S N C$ ( 2$)$,

-OILSH (3), RAWSH (3), SPENTS (3), OIL (3), ARSNC (3),

-OILSH( 4 ), RAWSH (4), SPENTS (4), OIL (4), ARSNC ( 4$)$

2000 FORMAT (IHI, 5X, INPUT OILSH: *2X,EI2.5/1X, *ELEMENT*, TI6, - INPUT OILSHALE*,

-T31, *RAW SHALE*, T46, "SPENT SHALE*, T61, O1L*,T81, *ARSENIC*,

$-|X, 105(*-*)|$

$-[X,-A S H *, T 16, E[2.5,4(3 X, E 12,5) /$

- (X, "SULFUR*,T16,E12.5,4(3X,E12.5)/

$-I X$, *ANTIMONY*,TI6,E $12.5,4(3 X, E 12.5) /$

-IX. *ARSENIC* T $16, E I 2.5,4(3 X, E 12.5))$

HRI TE (2,200 I ) OILSH(5), RAHSH (5), SPENTS (5), OIL (5), ARSNC (5), -OILSH (6), RAWSH(G), SPENTS (6), OIL (6), ARSNC (6), -OILSH (7), RAWSH (7), SPENTS (7), OIL (7), ARSNC (7): $-0 I L S H(8)$, RAWSH $(8)$, SPENTS (8), OIL (8), ARSNC (8)

2001 FORMAT (1X. "BERYLLIUM*,T16,E I2.5,4(3X,E12.5)/ $-1 X,+$ CADMIUH*, T16,EI2.5,4(3X,EIC.5)/

-1X, *CHROMIUM", T16.EI2.5,4(3X,E12.5)/

$-1 X$, .COPPER*, T 16,E12.5,4(3X,E12.5))

WR I TE (2, 2002) OILSH (9), RAWSH (9), SPENTS (9), OIL (9), ARSNC (9), -O1LSH(10), RAWSH (10), SPENTS 110$), 01 L(10)$, ARSNC $(10)$, -OILSH( 11$)$, RAWSH (11),SPENTS 111 , OIL (11), ARSNC (11); -OILSH(12) RAWSH (12), SPENTS (12), OIL (12), ARSNC (12)

2002 FORMAT ( IX.*IRON*, TIS,EI2.5,4(3X,EIZ.5))

$-1 X, * L E A D *, T 16, E 12,5,4(3 x, E 12.5) ;$

$-1 X$. *MAGNESIUM*.T $16, E 12.5,4(3 X, E 12,5) /$

$-1 X$, *MANGANESE*. T IS,E $12.5,4(3 X, E 12.5)$ )

WR I TE (2, 200310ILSH (13), RAWSH (13), SPENTS (13), OIL (13), ARSNC (13)

,- OILSH (14), RAWSH ( 14 ), SPENTS ( 14), OIL (14), ARSNC (14), -OILSHI 15), RAWSH ( 15), SPENTS (15), OIL (15), ARSNC (15),

-OILSH (16), RAWSH ( 16), SPENTS (16), OIL (16), ARSNC (16)

2003 FORMAT ( IX, +MERCURY , T16,EI2.5,4(3X,E12.5)/

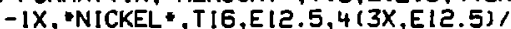

-1X. *SELENIUM*,TIG,E12.5,4(3X,E12.5)/

-1X. *SILYER*, TIG,Ei2.5,4(3X,Ei2.5))

WRITE ( 2,2004 ) OILSH (17), RAWSH (17), SPENTS (17), OIL (17), ARSNC (17)

,$- 0 I L S H(18)$, RAWSH (18), SPENTS (18), OIL (18), ARSNC (18).

-OILSH(19), RAHSH (19), SPENTS (19), OIL (19), ARSNC (19).

-OILSH(20), RAWSH(20), SPENTS(20), OIL (20), ARSNC (20) 


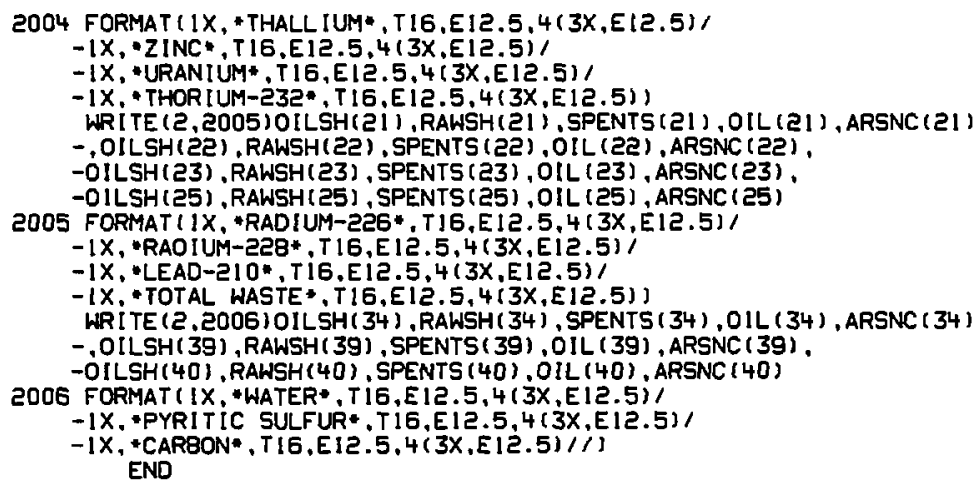




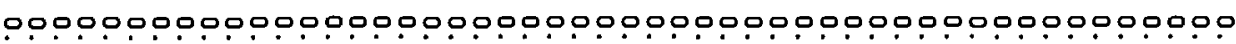

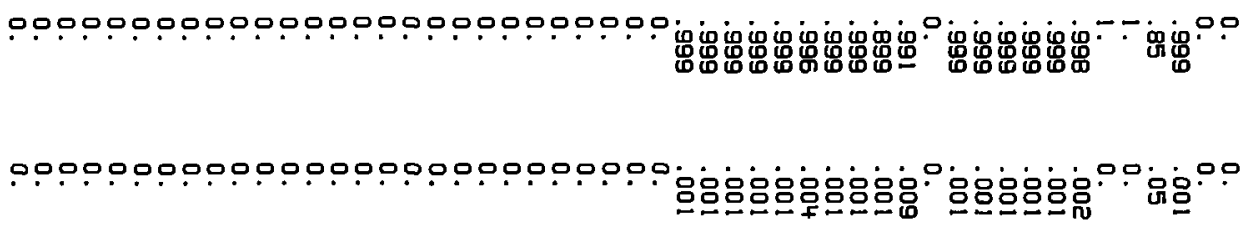




\begin{tabular}{|c|c|c|c|c|c|}
\hline $\begin{array}{l}\text { INPUT OIL } \\
\text { ELEMENT }\end{array}$ & $\begin{array}{l}\text { SH: } \\
\text { INPUT OILSHALE }\end{array}$ & $\begin{array}{l}+06 \\
\text { RAW SHALE }\end{array}$ & SPENT SHALE & OIL & ARSENIC \\
\hline $\begin{array}{l}\text { ASH } \\
\text { SULFUR } \\
\text { ANT IMONY } \\
\text { ARSENIC } \\
\text { BERYLL IUM } \\
\text { CADMIUM } \\
\text { CHROMIUM } \\
\text { COPPER } \\
\text { IRON } \\
\text { LEAD } \\
\text { MAGNESIUM } \\
\text { MANGANESE } \\
\text { MERCURY } \\
\text { NICKEL } \\
\text { SELENIUM } \\
\text { SILVER } \\
\text { THALLIUM } \\
\text { ZINC } \\
\text { URANIUM } \\
\text { THORIUM-232 } \\
\text { RADIUM-226 } \\
\text { RADIUM-22B } \\
\text { LEAD-2II } \\
\text { TOTAL WASTE } \\
\text { WATER } \\
\text { PYRITIC SULFUR } \\
\text { CARBON }\end{array}$ & $\begin{array}{l}0 . \\
.70000 E+03 \\
.15000 E+00 \\
.40000 E+01 \\
10000 E+00 \\
.10000 E+00 \\
.35000 E+01 \\
.40000 E+01 \\
.47200 E+04 \\
.25000 E+01 \\
.15500 E+04 \\
.25000 E+02 \\
.20000 E-01 \\
.25000 E+01 \\
15000 E+00 \\
.10000 E-01 \\
.10000 E-01 \\
.70000 E+01 \\
.37000 E+00 \\
.12000 E+01 \\
.12506 E-06 \\
.48120 E-09 \\
.16169 E-08 \\
0 . \\
0 . \\
.40000 E+03 \\
.10465 E+05\end{array}$ & $\begin{array}{r}0 . \\
.35000 E+02 \\
.75000 E-02 \\
.20000 E+00 \\
.50000 E-02 \\
.50000 E-02 \\
.17500 E+00 \\
.20000 E+00 \\
.23600 E+03 \\
.12500 E+00 \\
.77500 E+02 \\
.12500 E+01 \\
.10000 E-02 \\
.12500 E+00 \\
.75000 E-02 \\
.50000 E-03 \\
.50000 E-03 \\
.35000 E+00 \\
.18500 E-01 \\
.60000 E-01 \\
.62530 E-08 \\
.24060 E-10 \\
.80845 E-10 \\
.50000 E+04 \\
0 . \\
.20000 E+02 \\
.52325 E+03\end{array}$ & $\begin{array}{l}0 . \\
.52535 E+03 \\
.14236 E+00 \\
.32300 E+01 \\
.95000 E-01 \\
.95000 E-01 \\
.33184 E+01 \\
.37962 E+01 \\
.44795 E+04 \\
.23726 E+01 \\
.14710 E+04 \\
.23726 E+02 \\
.91200 E-03 \\
.23536 E+01 \\
.12811 E+00 \\
.94905 E-02 \\
.94905 E-02 \\
.66234 E+01 \\
.35115 E+00 \\
.11389 E+01 \\
.11869 E-06 \\
.45668 E-09 \\
.15345 E-08 \\
.79800 E+05 \\
.38000 E+04 \\
.30020 E+03 \\
.79534 E+03\end{array}$ & $\begin{array}{l}0 . \\
.53200 E+02 \\
.14250 E-03 \\
.19000 E+00 \\
0 . \\
0 . \\
.66500 E-02 \\
.38000 E-02 \\
.44840 E+01 \\
.23750 E-02 \\
.14725 E+01 \\
.23750 E-01 \\
.98800 E-03 \\
.21375 E-01 \\
.14250 E-03 \\
.95000 E-05 \\
.95000 E-05 \\
.26600 E-01 \\
.35150 E-03 \\
.11400 E-02 \\
.11881 E-09 \\
.45714 E-12 \\
.15361 E-11 \\
.10138 E+05 \\
0.130400 E+02 \\
.30400 E \\
.69592 E+04\end{array}$ & $\begin{array}{l}0 . \\
0 . \\
0 . \\
0 . \\
0 . \\
0 . \\
0 . \\
0 . \\
0 . \\
0 . \\
0 . \\
0 . \\
0 . \\
0 . \\
0 . \\
0 . \\
0 . \\
0 . \\
0 . \\
0 . \\
0 . \\
0 . \\
0 . \\
0 . \\
0 . \\
0 . \\
0 .\end{array}$ \\
\hline
\end{tabular}




\section{RADIONUCLIDES}

\subsection{Radionuclides Included in the Solid Waste Modules}

Radionuclides are Important constituents of coal and oll shale and it was decided that a number should be included in the solid waste modules. The reasons for including the following radionuclides are given below.

Radionuclides Produced by Cosmic Rays. The longest-lived radionuclide, $\mathrm{Be}^{10}$, has a half-life of only $2.5 \times 10^{6}$ years, ${ }^{1}$ and can thus be 1gnored. $\mathrm{C}^{14}$ is discussed separately below.

Carbon-14. $\mathrm{C}^{14}$ is a radionuclide produced in the upper atmosphere by cosmic rays (and also in nuclear power plants). When plants die, their $\mathrm{C}^{14}$ is in equilibrium with that in air. However, since its half-11fe is 5730 years, there is very little left in coal.

Primordial radionuclides. The most important of these radionuclides, potassium-40, has a half-1ife of $1.26 \times 10^{9}$ years and is a significant contributor to natural radiological dose.1 Rubidium-87 is also worth consideration. However, because of the very long half-life of primordial radionuclides and the fact that their concentration in coal is no greater than in the earth's crust, there is no reason to treat them separately from the element as a whole in the data base and transport equations. They can be broken out at any time using the known amount per mass of the total element.

Radioactive isotopes of potassium and rubidium always occur as a constant fraction of the total element; there is no relative body buildup of the radloactive isotopes and hence no changes in health effects. 
Since potassium and rubidium are not being considered as trace elements, it was decided there was no reason to include their radioactive 1sotopes.

Naturally Occurring Decay Chains. There are three naturally occurring decay chalns: . (1) urant um series headed by $U^{238}$, (2) actinium serles headed by $\mathrm{U}^{235}$, and (3) thorium series headed by $\mathrm{Th}^{232}$. The main sequences of nuclides for each of these are given in Tables 7.1 to 7.3.

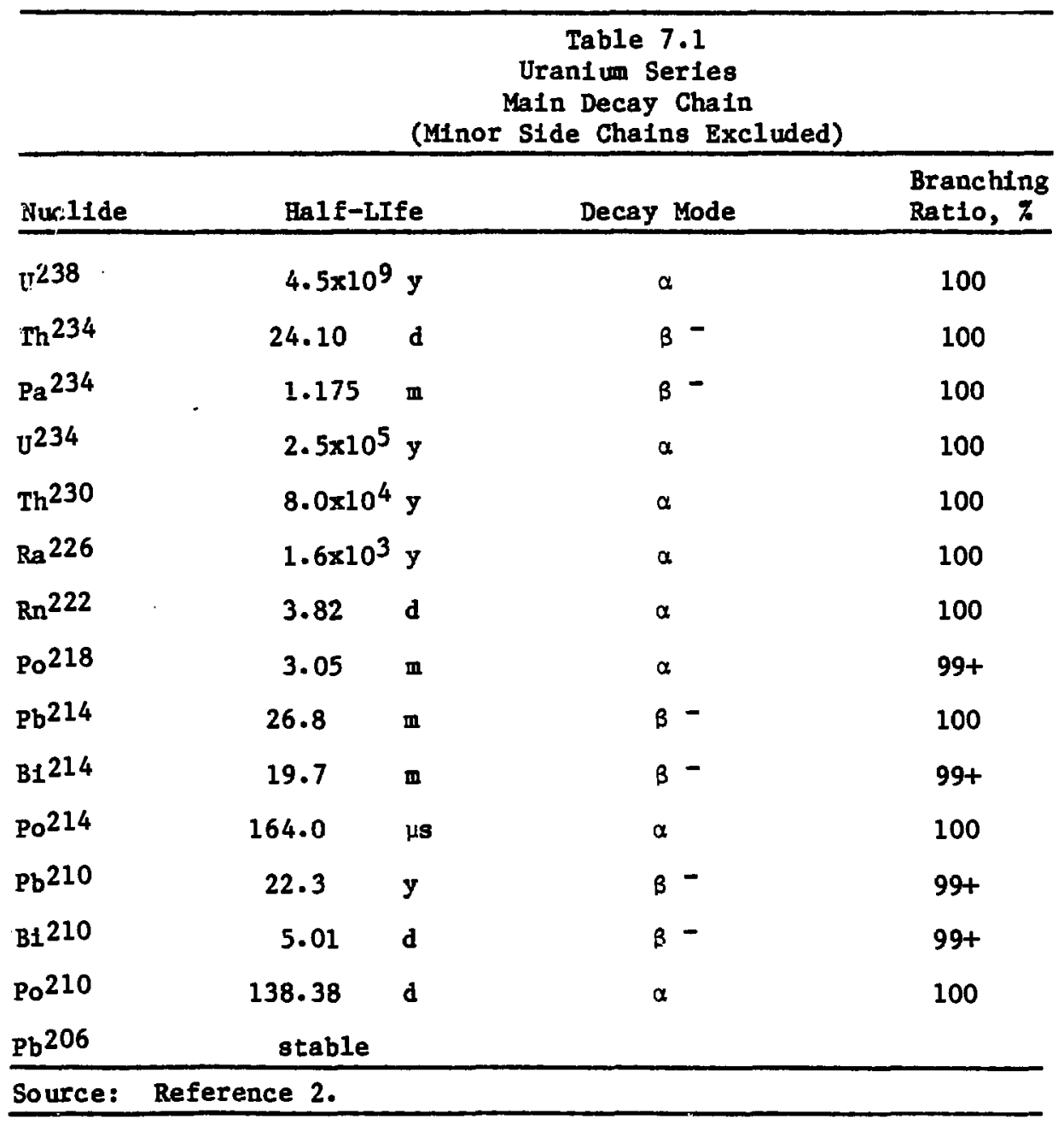




\begin{tabular}{|c|c|c|c|c|}
\hline \multirow[b]{2}{*}{ Nuclide } & \multicolumn{4}{|c|}{$\begin{array}{c}\text { Table } 7.2 \\
\text { Actinium Series } \\
\text { Main Decay Chain } \\
\text { (Minor Side Chains Excluded) }\end{array}$} \\
\hline & Half-LIfe & Decay & Mode & $\begin{array}{l}\text { Branching } \\
\text { Ratio, } 7\end{array}$ \\
\hline 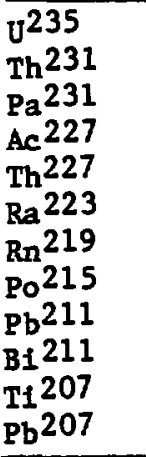 & $\begin{array}{l}7.0 \times 10^{8} \\
25.52 \\
3.3 \times 10^{4} \\
21.773 \\
18.718 \\
11.435 \\
3.96 \\
1.78 \\
36.1 \\
2.15 \\
4.77 \\
\text { stable }\end{array}$ & $\begin{array}{l}y \\
\text { h } \\
y \\
y \\
d \\
d \\
\text { s } \\
\text { ms } \\
\text { m } \\
\text { m } \\
\text { m }\end{array}$ & $\begin{array}{l}\alpha \\
\beta- \\
\alpha \\
\beta- \\
\alpha \\
\alpha \\
\alpha \\
\alpha- \\
\beta- \\
\alpha- \\
\beta-\end{array}$ & $\begin{array}{l}100 \\
100 \\
100 \\
98.6 \\
100 \\
100 \\
100 \\
99+ \\
100 \\
99.7 \\
100\end{array}$ \\
\hline Source: & ce 2. & & & \\
\hline
\end{tabular}

\begin{tabular}{|c|c|c|c|c|}
\hline \multirow[b]{2}{*}{ Nuc1Ide } & \multicolumn{4}{|c|}{$\begin{array}{l}\text { Table } 7.3 \\
\text { Thoriun Series } \\
\text { Main Decay Chain } \\
\text { (Minor Side Chains Excluded) }\end{array}$} \\
\hline & Ha1f-LIfe & Decay & Mode & $\begin{array}{l}\text { Branching } \\
\text { Ratio, } 7\end{array}$ \\
\hline $\begin{array}{r}\mathrm{Th}^{232} \\
\mathrm{Ra}^{228} \\
\mathrm{Ac}^{228} \\
\mathrm{Th}^{228} \\
\mathrm{Ra}^{224} \\
\mathrm{Rr}^{220} \\
\mathrm{Po}^{216} \\
\mathrm{~Pb}^{212} \\
\mathrm{BI}^{212} \\
\\
\text { (1) } \mathrm{Po}^{212} \\
\text { (2) } \mathrm{Tl}^{208} \\
\mathrm{~Pb}^{208}\end{array}$ & $\begin{array}{l}1.41 \times 10^{10} \\
5.76 \\
6.13 \\
1.91 \\
3.66 \\
55.6 \\
0.15 \\
10.64 \\
60.60 \\
0.3 \\
3.053 \\
\text { stable }\end{array}$ & $\begin{array}{l}y \\
y \\
b \\
y \\
d \\
\text { s } \\
\text { s } \\
\text { h } \\
\text { m }\end{array}$ & $\begin{array}{l}\alpha \\
\beta- \\
\beta- \\
\alpha \\
\alpha \\
\alpha \\
\alpha- \\
\beta- \\
\beta-(1) \\
\alpha \quad(2) \\
\alpha- \\
\beta-\end{array}$ & $\begin{array}{r}100 \\
100 \\
100 \\
100 \\
100 \\
100 \\
100 \\
100 \\
64 \\
36 \\
100 \\
100\end{array}$ \\
\hline
\end{tabular}


If the series is in secular equilibrium, the activities (divided by branching fraction to that daughter) of all daughters are the same. Thus, given the amount of any one nuclide, the amounts of the others can be calculated knowing the half-life and atomic weight:

$$
m(2)=m(1) \frac{T(2) A(2)}{T(1) A(1)}
$$

where

$$
\begin{aligned}
& m=\text { mass } \\
& A=\text { atomic welght } \\
& T=\text { half-life }
\end{aligned}
$$

In this case of the three decay chains, specifying the $U$ (natural) and $T h$ contents would be suffictent information. (Natural uranium 1 s $99.3 \% \mathrm{U}^{238}$ and $0.77 \mathrm{U}^{235}$ ). These are exactly the data given in the USGS coal data base.

Unfortunately, there are forces acting towards disequilibrium as the coal lies in its bed, during combustion, and in solld waste piles. For example, radium may be preferentially leached from waste piles. Thus, in theory, one must consider Individually three dozen odd major nuclides and many minor ones. However, in practice, one may consider only those daughters with long half-lives without compromising the accuracy of an assessment significantly. A list of these radionuclides is given below.

$\begin{array}{llll}\mathrm{U} & \text { Uranium } & \mathrm{Pb}^{210} & \text { Lead } \\ \mathrm{Th} & \text { Thorium } & \mathrm{Rn}^{222} & \text { Radon } \\ \mathrm{Ra}^{228} & \text { Radium } & \mathrm{Pa}^{231} & \text { Protactinium } \\ \mathrm{Ra} 226 & & \mathrm{Ac}^{227} & \text { Actinium }\end{array}$


While release of radon may be important when the disposal of the waste is consldered, Its release rate from waste plles can be calculated fron the amount of radium.

Inclusion of protactiniun and actinium are a refinement of $U^{235}$ decay chain effects which constitutes only $1 \%$ of the total uranium. Since data are not readily avallable for these elements, they w111 not be considered.

\subsection{Mass Calculations of Radium and Lead-210}

The mass of radium-226 and lead-210 in the input coal, oil shale and Iimestone can be calculated from the uranium-238 and that of radium-238 fropm the thosium-232, using the following equations and assumptions.

\subsubsection{When Assuming Secular Equilibrium}

The relevant principle here is that the branching ratio-weighted activity of any nuclide in a chain is equal to any other. Then, since the activity is proportional to $\mathrm{M} / \mathrm{AT}$,

$$
M_{b}=M_{a} \frac{B R_{b}}{B_{a}} \frac{A_{b}}{A_{a}} \frac{T_{b}}{T_{a}} \text {, }
$$

where

$$
\begin{aligned}
& M=\text { mass } \\
& B R=\text { branching ratio to the nuclide } \\
& A=\text { atomic weight } \\
& T=\text { half-life }
\end{aligned}
$$


7.2.2 When Relative Activities Avallable

where

$$
M_{b}=r(b / a) M_{a} \frac{A_{b}}{A_{a}} \frac{T_{b}}{T_{a}} \text {, }
$$

$r(b / a)$ is the ratio of activity "b" to activity " $a$ ".

7.2.3 Special Case: $B R_{x}=1$

Since all of the decays flow through $\mathrm{Ra}^{226}, \mathrm{~Pb}^{210}$, and $\mathrm{Ra}^{228}$ in their decay chalns, $B R=1$. Thus we can use the equation

$$
M_{b}=r(b / a) M_{a} \frac{A_{b}}{A_{a}} \frac{T_{b}}{T_{a}} \text {, }
$$

with the understanding that $r(b / a)=1$ in secular equilibrium.

Substituting in the following values results in the coefficients given

\begin{tabular}{|c|c|c|c|}
\hline Nuclide & A & $T$ (years) & $\mathbf{A T}$ \\
\hline v238 & 238 & $4.47 \times 10^{9}$ & $1.06 \times 10^{12}$ \\
\hline $\mathrm{Ra} 226$ & 226 & $1.60 \times 10^{3}$ & $3.62 \times 10^{5}$ \\
\hline $\mathrm{Pb} 210$ & 210 & 22.3 & $4.68 \times 10^{3}$ \\
\hline$T h 232$ & 232 & $1.41 \times 10^{10}$ & $3.27 \times 10^{12}$ \\
\hline $\mathrm{Ra} 228$ & 228 & 5.76 & $1.31 \times 10^{3}$ \\
\hline $\begin{array}{l}\mathrm{M}_{\mathrm{Ra}} 226 \\
\mathrm{M}_{\mathrm{Pb}} 210\end{array}$ & $\begin{array}{l}J^{-7} \\
j^{-9}\end{array}$ & $\begin{array}{l}\left.6 / \mathrm{U}^{238}\right) \mathrm{MU}^{-} \\
\left..0 / \mathrm{U}^{238}\right) \mathrm{MU}^{-}\end{array}$ & \\
\hline
\end{tabular}
below:

The conversions include the fact that $U^{238} / U$-natural is 0.993 and Th-natural is essentially all $\mathrm{Th}^{232}$.

Until further data become avallable, secular equilibrium and therefore a ratio of activity of 1 is assumed. 